\title{
PARAGUACU PAULISTA \\ contribuição para o estudo de um centro local do extremo sudoeste paulista.
}

Dissertaçăo de Mestrado apresentada ao Departamento de Geografia da Faculdade de Filoso. fia, Letras a Ciências Humanas da Universidade de Săo Paulo. 
PARAGUAÇU RAULISTA: contribuição para

o estudo de um centro local do extre

mo Sudoeste Paulista.-

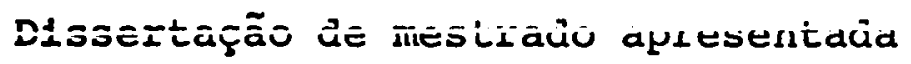
ao Departamento de Geografia da Fa culdade de Filosofia, Letras e Ciên cias Humanas da Universidade de são Paulo, pelo licenciado ARMANDO GARMS e sob a orlentação do Professor Dou tor PASQUALE PETRONE.-

São Paulo

1977 


\section{IN D I C E}

Pag.

Capitulo $1:-$ INTRODUÇÃ $\ldots \ldots \ldots \ldots \ldots \ldots \ldots \ldots \ldots \ldots$

1.1. Justificativa, Revisão Bibliográfica e

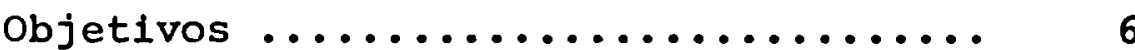

1.2. Caracterização Sumāria do Objeto de Es tudo ......................... 8

1.3. Procedimento da Pesquisa ........... 9

Capítulo 2:- O POVOAMENTO E A OCUPAÇÃO DA ALTA SOROCABANA

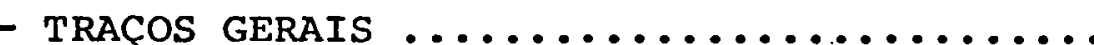

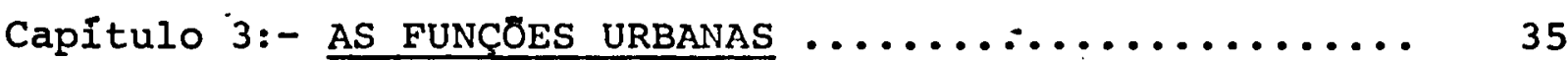

3.1. Evolução das Funções $\ldots \ldots \ldots \ldots \ldots \ldots \ldots . . \ldots$

3.2. As Funções Atuais ................ 48

3.2.1. A Função "Industrial": Coleta, Beneficiamento e Expedição de Produtos Primários ........... 48

3.2.1.1. Origem dos capitais ... 50

3.2.1.2. Controle e Gestão .... 53

3.2.1.3. Matēria-Prima ........ 55

3.2.1.4. Produção e Mercado Con sumidor ............ 58

3.2.2. A Função de Distribuição de Pro dutos Industriais e Agrārios ... 65

3.2.2.1. Origem dos Capitais ... 69

3.2.2.2. Controle e Gestão ..... 74

3.2.2.3. Abastecimento do comêr cio ............... 77

3.2.2.4. Mercado Consumidor .... 80

3.2.3. A Função de Serviços .......... 85

3.2.3.1. A Função Bancária ..... 86

3.2.3.2. A Função Eảucãcional .. 88

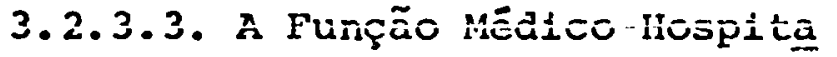
lar ............... 91 
3.2.3.4. A Função Político-Admi nistrativa .......... 93

3.2.3.5. A Função de Transportes 94

3.2.4. A Função de Residência de Proprí etários e Assalariados Rurais .. 99

3.2.4.1. Os Proprietários Rurais 99

3.2.4.2. O Assalariado Rural ... 107

Capitulo $4:-$ A POPULACÃO URBANA $\ldots \ldots \ldots \ldots \ldots \ldots \ldots \ldots . \ldots 114$

4.1. Evolução da População Municipal ...... 114

4.2. Estrutura da.População e Pirâmide das Idades . . . . . . . . . . . . . . ... 123

4.3. Mortalidade e Natalidade ........... 127

4. 4. Proveniência Espacial da População Urbą na ............................ 134

4.5. Estrutura Profissional da População Uي bana ............................ 143

4.6. Estrutura Econômica da População Urbana 150

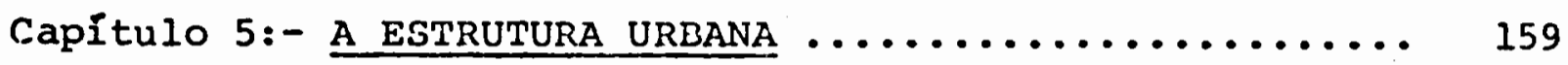

5.1. o sitio Urbano ................. 159

5.2. A Morfologia Urbana .............. 162

5.3. O Equipamento Público ............ 168

5.4. Espaço Livre, Espaço Construído e Popü lação ....................... 179

5.5. Origen! e Evolução do Centro Urbario .... 185

5.6. Estrutura Urbana ................ 196

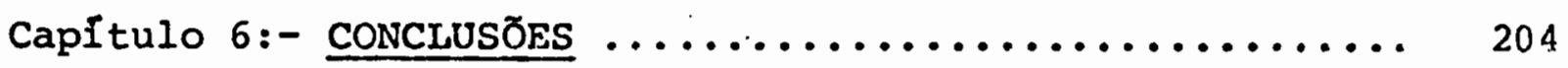

BIBLIOGRAFIA $\ldots \ldots \ldots \ldots \ldots \ldots \ldots \ldots \ldots \ldots \ldots \ldots \ldots \ldots \ldots \ldots \ldots$

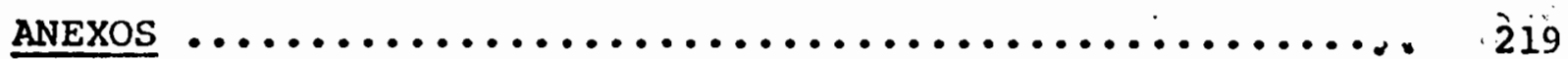




\section{Capitulo 1 - Introdução}

1.1. Justificativa, revisão bibliogrâa fica e objetivos

1.2. Caracterização sumária do objeto de estudo

1.3. Procedimento da Pesquisa 
1 - Introducão

\subsection{Justificativa, revisão bilbiogräfica e objetivos}

A escolha de Paraguaçu Paulista como tema de pesquisa vol tada ao mestrado, liga-se ao fato de que a nossa vivência ao lon go de vários anos nesta cidade proporcionou um conhecimento sô bre esta e áreas próximas, ao lado de um bom relacionamento que nos permitiria o acesso e obtenção de dados einformações necessārias dos diferentes setores citadinose a solicitação pela Admí nistração Municipal paraguaçuense para que cooperássemos na ela boração do Plano Diretor de Desenvolvimento Integrado. Entretan to, maior justificativa fol a preocupação em conhecer e caracte rizar o comportamento de uma pequena cidade da rede de cidades da Alta Sorocabana, uma das componentes 1nterioranas, no oeste paulista, do gránde espaço periférico da metrópole paulistana.

De modo geral, os temas de Geografia Urbana no Brasil fo ram tratados segundo algumas tendências:

- Estudos de médias cidades, com trabalhos realizados plin cipalmente através àos Congressos e Assemilēias da Associação dos Geógrafos Brasileiros, face à viabilidade do carāter monogrā fico para este nível de centro urbano, não acontecendo o mesmo para as grandes cidades, cuja exceção é o trabalho "A cidade de São Paulo - Estudos de Geografia Urbana", realizado pela A.G.B., Seç̧ão Regional de são Paulo, e dirıgido pelo Professor Aroldo de Azevedo (1958). Quanto às pequenas cidades, apresentam-se de sinteressantes como objeto de investigação e seus estudos sãora ros. Nesta tendêncla, isto è, estudos das cldades médias, alguns exemplos podem ser citados: Campina Grande (PB-1952), Cuiabā MT1953), Ribeirão Preto (SP-1954), Santa Marla (RGS-1958), Londri na(PR-1961), Blumenau (SC -1966).

-Estudos Interessando as relaçōes homem-melo, caracterizan do-se estes pelos trabalhos sobre redes urbanas, dando-se ênfase à "cabeça" da rede, normalmente uma capital ou metrōpole regio nal. Dentro desta linha temos: os estudo realizado pelo Grupo de Trabalho de Geografia Urbana do Conselho Nacional de Geografia , sôbre a organização urbana na região do Rio de Janeiro (1964); o trabalho de Pedro Pinchas Geiger "Evolução da Rede Urbana Brasi leira" (1953); O trabaino de Nice Lecocq Mthller "O Fato Urbano na Bacia do Rio Paraiba - São Paulo" (1969). 
- Estudos de temas setoriais e espaciais: porto,indústria, metropolização, abastecimento, etc., podendo-se exemplificar es ta tendêncla atravēs do trabalho de José Ribelro de Araujo Fi Iho "Santos, o porto do café" (1969); de Lea Goldenstein "Estudo de um centro industrial satélite - Cubatão" (1970); de Judith De La Corte "Contribuição ao estudo do abastecimento da cidade de são Paulo em produtos hortifrutícolas" (1973).

- No momento atual, ao lado das tendências precedentes que continuam a multiplicar os temas de Geografia Urbana, surge - interesse pelas pequenas cidades, porque estas estão em crise face ao processo de concentração urbana. Esta nova tendêncla a presenta um número crescente de estudos reallzados e apresentados principalmente na forma de trabalhos de mestrado, entre os quais citamos: de Rosa Ester Rossini "Serra Azul: o Homem e a Cidade" (1971); de Paulo Pedro Perides "Dols Córregos: um exemplo de cen tro local" (1971); de Satie Mizubuti "Itaboral - Estudo deGeogra fia Urbana" (1972).

No caso especifico do oeste paulista, os estudos de Geo grafia Urbana orientam-se essencialmente para as médias cidades, sendo raros aqueles realizados para pequenos ñúcleos, e relativa mente antigos. Como exempios temos: Assis Cintra "Araraquara imu niclpio, cidade e o pove)" (1928); Pierre Monbeig "Algumas obser vaçōes sôbre Marilia, cidade pioneira" (1941), (mesmo Monbeig em seu trabalho - "Pionniers et Planteurs de São Paulo" (1952), ao tratar das cidades da frente pioneira, dá destaque especial às cldades médias); Odilon Nogueira Matos "Rápido Estudo de um cen tro urbano - Jaboticabal" (1942); Olga Pantaleão "A cidade de Catanduva" (1944); Josē Ferrari Leite "A Alta Sorocabana e o es paço polarizado de Presidente Prudente" (1972). Alguns poucos so bre a pequena cidade e entre estes: Otacilio Dias "A cidade de Palmital e o município" (1944); Ely Goulart Pereira de Araujo "A cidade de Olimpia: estudo de Geografia Urbana" (1952).

Nosso estudo, por sua vez, tem por objetivo a concretização de monografla sobre um dos vários pequenos centros da rede de cidades da Alta Sorocabana, dentro de uma perspectiva de anā IIse do comportamento desta pequena cidade em um espaço onde 0 processo de ocupação e a vida de relações resultaram das neces sidades externas a este espaço, e onde o fenômeno da concentraçáo urbana gera desequilibrios em favor das mêdias e grandes cidacies, restando às pequenas a busca, muito mals dificil, dos melos para a sua permanência e sobrevivência. 
Nas considerações destes fatos, as seguintes questões de ordem geral estarão presentes direcionando o desenvolvimento de nosso estudo na sua totalidade:

- Como se define Paraguaçu Paulista na rede da Alta Soro cabana e em face do processo de ocupação deste espaço?

- Qual o papel da pequena cidade, a exemplo e ao nível de Paraguaçu Paulista, face à intensificação do processo de concentração urbana, considerando-se as relações cen tro-periferia a partir da metrópole paulistana, e quais as razões ou fatos de sua permanêncla e sobrevivência neste espaço periférico?

- Face a estas Indagações e consideraçōes e nas circuns tâncias em que o fenômeno se desenvolve e levando-se em conta ainda a sua presença na ărea de dominação de duas capitais regionais - Presidente Prudente e Marilia - co mo se comporta Paraguaçu Paulista?

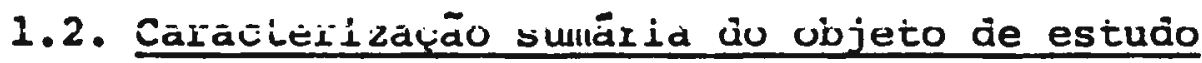

Paraguaçu Paulista encontra-se no Sudoeste do Estado de São Paulo, a aproximadamente $500 \mathrm{~km}$ da capital (1), na região conhecida como Alta Sorocabana (2). Constitul a região espaço compreendido pelo espigão divisor dos rios do Pelxe (N) e Parana panema ( $S$ ).

Atravēs de critērio considerando o espaço como forma de organização da produção (micro-regiōes homogêneas), aliado ao processo de ocupação do oeste paulista e em particular o extremo sudoeste do Estado, Paraguaçu Paulista constitui espaço vincula do à Alta Sorocabana sob a dominação de Presidente Prudente. En tretanto, considerando-se o critério onde o espaço se organiza èm função de uma economia de mercado e de serviços, principalmen

(1) A cidade de Paraguaçu Paulista, sede do município de mes mo nome, dista da capital paulista $475 \mathrm{~km}$ por rodovia as faltada (Raposo Tavares) e $596 \mathrm{~km}$ por ferrovia (FEPASA) no trecho ferroviärio correspondente ao Ex-Estrada de Ferro Sorocabana).

(2) Leite, José Ferrari - "A Alta Sorocabana e o espaço polari zado de Presidente Prudente". F.F.C.e Letras de Presidente Prudente, 1972 , päg. 14. 
te administrativos, o municipio em questão encontra-se encravado na 1la. Região Administrativa de Marilia, Sub-Região de Assis ( 3 ). (Cartograma 1).

De acordo com o Censo de 1970, o municlpio paraguaçuense contava 21.892 habitantes, com uma ārea de $1043 \mathrm{Km}^{2}$, o que lhe proporcionava densidade média de 21 habitantes $/ \mathrm{km}^{2}$. A população urbana estava constituída de 14.011 pessoas, enquanto que a zona rural somava 8.058. Considerando-se a Sub-Região de Assis, estes números paraguaçuenses correspondiam a 12,38 da população total, 14,88 da população urbana, 9,58 do contingente rural e 16,88 da área sub-regional.

o espaço municipal está constituido por três distritos: o da sede - Paraguaçu Paulista -, Concelção de Monte Alegre e Sape sal. o de malor contingente populacional é aquele da sede com 76,78 do total do município, seguido por Concelção de Monte Ale gre com 15,68, e Sapezal com 7,78. Em termos de população urba na, una vez que cada distrito tem o seu núcleo, a sede possui 96,28, restando a Concelção de Monte Alegre, 1,78, e a Sapesal 2,18. A população rural apresenta certo equilibrio na distribui ção entre o distrito da sede e Concelção dé Monte Alegre: 42,98 para o primeiro e 39,68 para o segundo. Sapesal engloba os de mais 17,58. (Cartograma 2).

\subsection{Procedimento da Pesquisa}

- trabalho se desenvolveu através de uma etapa de coleta e obtenção de dados e outra de trabalho de gabinete. Contudo, ca be ressaltar que embora se faça esta divisão, as etapas não fo ram estanques ou compartimentadas no decorrer da elaboração do trabalho, ou seja, à medida que dados e fatos eram coletados, ob servados, anotados, em várias vezes e momentos constituiram de imediato objeto de trabalho de gabinete.

A primeira etapa apreendeu dados contidos num espaço de tempo suficientemente amplo para permitir a confirmação dos fa

(3) Segundo o Censo de 1970, a 11a.Região Administrativa de Ma rília (46 municípios) soma 676.180 habitantes, significan do 3,8\% da populaça estadual. Neste Censo, a Sub-região = de Assis (13 municipios) contava 177.231 pessoas (26\% da população regional), sendo 93.169 urbanos e 84.062 rurais, ocupando uma área aproximada de $6.200 \mathrm{~km}$. 
MUNICIPIO DE PARAGUACU PAULISTA

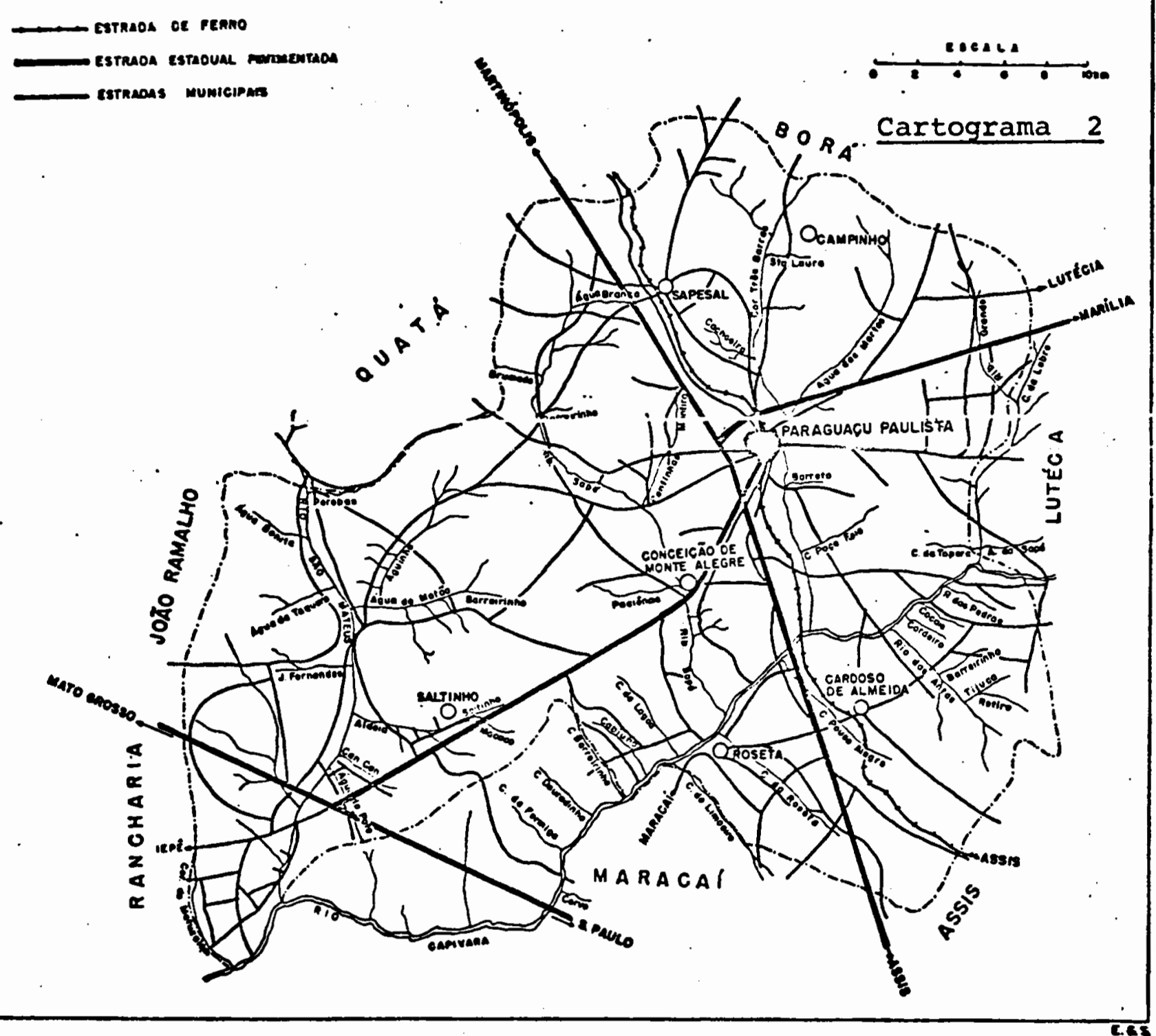


tos que melhor caracterizassem o objeto de nosso estudo. Desta' forma inventariamos dados 1solados ou sistematizados, oferecidos por publicações oficlais, jornais, depolmentos, etc.

Ao meșmo tempo, a coleta e obtenção de dados se ordenou em três níveis: ao nÍvel nacional, ao nível estadual e ao nível local.

Ao nivel nacional:

- Coleta de dados económicos e populacionais dos Censos de $1900,1920,1940,1950,1960$ e 1970.

Ao nivel estadual:

- Levantamento e coleta de dados referentes à Estrada de Ferro Sorocabana - estações de Cardoso de Almeida, Paraguaçu Pau 1ista e Sapezal. As atividades foram realizadas na Biblioteca. central da Estrada de Ferro Sorocabana, Estação "Julio Prestes", nos relatórios da referida ferrovia, teño em vista o movimento geral das estações citadas, no período entre 1916 e 1940.

- Levantamento e coleta de dados referentes a nascimentos obitos gerais, martalidade infant1l, casamentos referentes a con ceição de Monte Alegre, Paraguaçu Paulista e Sapesal, nn nerínan entre 1891 e 1939. As informaçōes foram obtidas nos Anuārios Es tatísticos do Estado de São Paulo, existentes no Arquivo do Esta do.

- Levantamento e coleta de dados referentes a nascimentos, óbitos gerais, mortalidade infantil, casamentos, do Município de Paraguaçu Paulista, destacando-se a sede e os distritos. As In formações buscadas referiam-se ao periodo entre 1940 e 1969, e fo ram obtidas nos Boletins, Anuários Estatisticos, material mimeo grafado, dat1lografado, existentes no Departamento de Estatist 1 ca do Estado de são Paulo.

- Levantamento e coleta de dados do movimento bancário em Paraguaçu Paulista, paraos anos de 1972 e 1973 (último trimestre), obtidos através das publicações da Divisão de Estatisticas Econô micas da Secretaria de Economia e Planejamento do Estado de são paulo.

- Levantamento e coleta de dados e material cartográfico junto ao Instituto Geográfico e Geológico do Estado de São Pau 10.

- Coleta de dados do Recenseamento Demográfico,Escolar, $\underline{A}$ grícola e Zootécnico do Estado de São Paulo, ano de 1934. 
Ao nivel local:

Foram realizados inicialmente os primeiros contatos junto à Agência Municipal do IBGE, Prefeitura Municipal, Casa da Lavou ra, Biblioteca Municipal, para tomada de conhecimento das fontes existentes, passiveis de consulta e, ao mesmo tempo, obter infor mações para outras fontes e consultas.

- Levantamento bibliográfico, procurando fontes que trá tassem especificamente do tema em questão. Entretanto, esta fase revelou-se pobre, restringindo-se ao Plano Municipal de Desenvol vimento Rural, ao trabalho de mestrado, em andamento, de Márcio Antonio Teixeira "A organização do espaço rural do município de Paraguaçu Paulista", e aos artigos e fatos relatados nos jornais locais: "A Semana" e "A Comarca" (este de circulação encerrada), ambos hebdomadārios. Verificou-se, tambēm, que a cidade e municí pio são tratados e vistos em outros trabalhos, trabalhos estes voltados para um contexto regional $e$, mesmo assim, constituem ' não mais que uma dezena de títulos, dos quais há que se destacar a obra de Pierre Monbeig "Pionniers et Planteurs de São Paulo".

- Levantamentos e coleta de dados junto à Prefeitura Munić1 nal de Paraguaçu Pạlista:

a. material cartográfico: plantas da cidade de diferen tes datas, nas escalas $1: 2.000 ; 1: 4.000 ; 1: 8.000$, 0 que nos per mitiu verificar a evolução do centro urbano não só quanto à sua expansão territorial, bem como dos diferentes serviços públicos (ăgua, esgoto, 1luminação pública, asfalto, etc...)

b. Consulta aos Livros de Registro de Indústria e Pro fissões dos anos 1938, 1960, 1974, tendo em vista comparar e pro curar obter a evolução das diferentes atividades urbanas paragua ģuenses.

c. Consulta às declarações de Dados Informativos Neces sários à Apuração dos Indices de Participação dos Municípios pau listas no Produto da Arrecadação do I C M, exigidos pela fiscalí zação da Secretaria da Fazenda do Estado de São Paulo, cujas có pias ficam arquivadas na Prefeitura Municipal. Foram consultadas 1008 das Declarações modelo "A" ( 314 ) e modelo "B" ( 358 ) referentes ao ano de 1974. As informações e dados coletados nes tas declarações constituiram elementos fundamentais no estudo das funções, seja na definição de cada uma delas, seja na definí ఢ̧ão funcional do centro urbano, seja, atravēs do estabelecimento das relaçōes espaciais entre as funções, na caracterização da de 
pendência e Influência tida e exercida por Paraguaçu Paulista.

d. Consulta ao Cadastro Municipal (1974 e 1975), cujas in formaçōes abrangendo toda a cidade, calcadas na distribuição se torial utilizada pelo IBGE, quando do Censo de 1970, para Para guaçu Paulista, nos permitiram a elaboração de planta que consti tuiu conhecimento sintetizado das relaçōes espaço livre / espaço construído e as relaçōes destes espaços com a população urbana.

- Levantamentos no cartório da la. Circunscrição de Re gistro Geral de Hipotecas e Anexos da Comarca de Paraguaçu Paulis ta, cujas informaçōes e dados nos permitiram as considerações sô bre a evolução do espaço urbano: os primeiros lotes vendidos, os tipos de loteamentos, as orientações por estes definidas na ex pansão da cidade.

- Levantamentos nos diferentes estabelecimentos de ensino oficial ou particular, tendo em vista o conhecimento da evolução, situação atual, área de atendimento, tipos de cursos oferecidos, equipamentos, corpo docente e discente. Os fatos e dados foram buscados interessando tanto o global, quanto cada estabelecimento em particular.

- Levantamentos, coleta de dados e entrevistas junto ao Hospital de Caridade de Paraguaçu Paulista. Os levantamentos e coleta de dados foram feitos nos relatórios anuais da entidade , entre 1948 e 1973, e nas entrevistas junto à Administração do Hos pital e corpo médico. o objetivo constituiu o conhecimento e evo lução da entidade, ārea e tipo de atendimento, equipamento, "ne cessidades, tendências e papel do setor na estrutura funcional ' urbana.

- Entrevistas junto ao Agente local da EBCT, do IBGE, Dé legado do Serviço Militar, Chefe do Posto de Sementes, Chefe da Casa da Lavoura, procurando definir área de jurisdição, atendimen to e equipamento de cada um dos Orgãos sob sua direção e Instala dos na cidade, com o objetivo de verificar a presença da função' administrativa de diferentes niveis, a partir de Paraguaçu Paulis ta.

- Entrevistas nos estabelecimentos bancários (em nümero de quatro), visando a obtenção de informações quanto à área de atuação de linhas de crēdito, predominância das operações segun do diferentes setores de atividades.

- Entrevistas com antigos moradores, procurando obter in formaçōes, dados e fatos ligados a funções, população e estrutū ra urbana. Na escolha destes entrevistados levou-se em considera ção o conhecimento que tinham dos fatos buscados e a idoneida 
de de suas informações.

- Aplicação de questionārios.

A insuficlência edesatualização dos diferentes dados pụ blicados sobre Paraguaçu Paulista, na maioria das vezes dentro de um contexto geral, allados à preocupação de verificar o com portamento atual e tendência dos diferentes elementos da paisa gem urbana, nos conduziram à aplicação de questionários.

a. questionários interessando a população urbana.

Estes questionārios voltaram-se, por um lado, à obtenção de dados que conduzissem à caracterização da população quanto à sua estrutura por idade, sexo, socio-econômica, profissional e movimentos e, por outro lado, na obtenção de informaçōes indica tivas quanto ao abastecimento e alguns serviços procurados por esta população, informações estas que constituiram elementos ini cials de apoio para a aplicação de outros questionärios nestes setores,

Inicialmente foram aplicados 500 questionärios em 500 re sidências urbanas, constituindo uma amostragem aproximada de $17 \%$ da população urbana. Foram respondidos de forma completa 948 . Pá ra sua aplicação foi utilizada a escolha aleatória, na proporção de uma residência em cada cinco, ocupadas. (modelo anexo). A a plicação ocorreu em meados de 1971.

Em outro momento, final de 1971, início de 1972, aplicouse um segundo questionário, tendo em vista a correção de possî veis erros e o reforço de fatos e dados obtidos através do prí meiro questionário. Este segundo voltou-se essencialmente aos da dos e fatos populacionais. Foram aplicados 1.000 questionários ' em 1.000 residências, tendo sido respondidos de forma completa 874, correspondendo a uma amostragem aproximada de 358 da popula ção urbana. Igualmente a escolha foi aleatória, ocorrendo, entre tanto, a proporção de duas residências para cada cinco, ocupadas. (modelo anexo).

b. Questionários interessando o comērcio.

Através dos questionários aplicados na população, obtevese a indicação dos estabelecimentos mais procurados quanto à ali mentação, vestuãrio e calçados. A partir desta orientação am pliou-se a amostragem, abrangendo esta pelo menos um estabeleci mento de cada atividade comercial existente na cidade, resultando na aplicação de 35 questionārios (modelo anexo), cujas indagações tinham em vista o conhecimento da evolução, estrutura e fun cionamento, relações espaciais de abastecimento e consumolatendi 
mento), conseqüentemente relações de influência ou dependência da função. Alēm deste tipo de questionärio, um outro, bastante simplificado (modelo anexo), fol aplicado (em número de 32 ) tendo como objetivo o reforço da definição da ārea de atuação das atividades do comércio paraguaçuense. Este tipo de questionā rio também fol aplicado em algumas atividades da função de servi ços, com o mesmo intento. Em ambos os casos, a aplicação ocorre entre 1972 e 1973.

c. Questionários interessando indústria.

Foram aplicados 18 questionários, (modelo anexo) neste se tor de atividades, o que, considerando-se o Censo Industrial de são Paulo - 1970 , abrangeram 308 dos estabelecimentos indus triais existentes em Paraguaçu Paulista. Entretanto, algumas at 1 vidades estão representadas por várias unidades, ocorrendo, em contrapartida, atividades representadas por apenas uma unidade industrial. Buscando una visão global do setor, procurou-se apli car o questionário em uma unidade de cada tipo de atividade in dustrial, ocorrendo, no caso de várias delas em um mesmo setor,ú ma escolha aleatōría. A aplicação ocorreu entre 1973 e 1974 e os objetivos voltaram-se para a apreensão da evolução,estrutura,com portamento atual e tendências do setor.

- A aplicação de questionários nos diferentes setores de atividades, na população da cidade, permitiram a obtenção dos primeiros indicadores para elaboração de planta funcional da mes ma. A elaboração final se efetuou atravēs de caminhamentos pelas ruas da cidade, observando, anotando e lançando, segundo conven çōes definidas anteriormente, elementos da morfologia urbana. o apolo cartográfico constituiu a planta da cidade na escala de 1:4.000, já existente, contendo apenas o traçado das ruas, seus nomes e alguns elementos morfológicos ligados principalmente aos serviços. Estes caminhamentos foram realizados em 1973.

- Para construção e anālise dos perfís topográficos da c1 dade e da seção Geológica entre os ribeirões do Alegre e Sapé, a polamo-nos na Carta do Brasil na escala de 1:50.000, folha SF-22Z-A-I-4-Paraguaçu Paulista, IBGE, 1974; nas observações e anota ções de campo, estas realizadas com a colaboração dos professo res José Martin Suarez (Geologia) e Hideo Sudo (Geografia Físi ca), ambos do Departamento de Geografla da F.F.C. e Letras de Presidente Prudente. Os trabalhos foram realizados no inicio de 1976.

Os trabalhos de gabinete constaram de: 
- Tabulação de dados e confecção de tabelas, através dos dados obtidos nos diferentes levantamentos e questionários.

- Reprodução, elaboração e confecção de gráficos, plantas e cartogramas.

- Interpretação das tabelas, grãficos, plantas, cartogra mas e redação do presente trabalho.

No desenvolvimento desta monografia, contamos com a orien tação do Professor Doutor Pasquale Petrone; com o apoio de nos sos colegas do Departamento de Geografia da F.F.C.e Letras de Presidente Prudente, com os quais as trocas de 1délas nos foram muito valiosas: 
Capítulo 2:- O POVOAMENTO E A OCUPAÇÄO DA ALTA SOROCABANA - TRACCOS GERAIS. 
2. O POVOAMENTO E A OCUPAÇÃO DA ALTA SOROCABANA - TRAÇOS GERAIS.

Os primeiros povoadores da região que compreende não só o município de Paraguaçu Paulista, mas uma área dêste às barrancas do rio Paraná e Paranapanema, são de origem mineira e remontam ao ano de 1876, embora todo o Oeste Paulista figurasse nos mapas da época como "TERRENOS DESCONHECIDOS". ( 4 )

o município pioneiro da área em estudo foi conceição de Monte Alegre, fundado em 1876, embora tenha sido instalado ofici almente apenas em 1913.

As informações iniciais sobre a população deste município datam de 1900, qùe nesta época possuía 1.703 habitantes. Er. 1920 sua população, em uma área aproximada de $9.993 \mathrm{~km}^{2}$, praticamente a mesma de 1900 uma vez que não houve desmembramentos, alcançava o total de 16.160 habitantes.

A partir de 1921 ocorre a criação de outros municípics e já, neste ano, era criado Presidente Prudente com terras cicsmen bradas dos municípios de Campos Novos Paulista e de Conceiçăi de Monte Alegre. Este novo município possuía uma extensão territori al aproximada de $15.600 \mathrm{~km}^{2}$, alcançando as suas divisas $\circ$ aivi sor das águas do Aguapei-Peixe ao norte, rio Paranapanema ao sul municípios de Campos Novos do Paranapanema e Conceição de i:onte Alegre a leste e rio Paraná a oeste. ( 5 ) Com desmembramentos' de seu território foram criados os municípios de Santo Anastácio (1925), Presidente Venceslau (1926), Presidente Bernardes (1935), Martinópolis (1938).

Do território montealegrense desmembraram-se Maracaí, Pa raguaçu Paulista e Quatā, em 1924, e Rancharia (1930) com parte cie terras deste e de Quatá. Ao final da década de 1930, Conccição' de Monte Alegre é anexado a Paraguaçu Paulista (1939) (Cartogra ma 3 ). 
o povoamento e ocupação desta área, dos fins do século passado até por volta de 1920, deu-se de forma lenta face às atí vidades exercidas, às dificuldades das relações espaciais e em virtude das hostilidades entre povoadores mineiros e grupos indí genas da região.

A principal atividade econômica destes pioneiros vindosde Minas Gerais estava voltada para a criação de suínos e bovinos. A criação de bovinos definiu-se mais para o oeste - vales dos rios Laranja Doce e Indiana - enquanto que a área mais próxima ao nú cleo de Conceição de Monte Alegre, a leste - vales dos rios são Mateus e Capivara - voltou-se para a criação e engorda de suínos. Além disto dedicavam-se a pequenas plantaçōes de cereais, batata doce e inglesa, mandioca, cana-de-açúcar, algodão; fabricavam rạ paduras, farinha grossa de milho, cobertores de algodão e lã, te cidos grosseiros, voltados para uma economia de subsistência. Nes tas atividades; antes de findar o sēculo passado, abre-se um pa rênteses a uma pequena e primeira tentativa de plantio de café, em 1876. ( 6 )

As relações a partir do município de Conceição de Nonte Alegre, para comercialização de seus produțos, principalmente par cós jā abatidos: salgados e rudimentarmente arnndicinnados e mes mo "em pé", bem como parcela excedente de sua economia agropecuá ria, faziam-se com as "praças" de são Manuel e Botucatu, onde adquiriam o sal grosso, querosene, tecidos, açúcar, fumo, fari nha de trigo, ferramentas. O percurso até são Manuel era feitoem carros de bois, que gastavam cerca de um mês na viagem de ida e volta. ( 7 )

Os relacionamentos entre o mineiro povoador e o indígena sempre foram difíceis e quase sempre sangrentos. Estes últimos atacavam, matavam e roubavam, mas no processo final o branco tex minava por expulsá-los cometendo, muitas das vezes violentas atro cidades. ( 8 )

\footnotetext{
(6) - Giovannetti, Bruno - "Esbōço Histórico da Alta Sorocaba na". Empresa Gráfica Revista dos Tribunais. São Paulo, 1943 , pag. 145.

( 7 ) - Giannasi, Humberto B. - "Conceição de Monte Alegre, sua Histōria e seu passado". Artigos publicados nos Jornal "A Semana", Paraguaçu Paulista, capítulo III, 26/04/70.

( 8 ) - Abreu, Dióres Santos - "Formą ão Histörica de uma cida de pioneira paulista: Presidente Prudente". F.F.C. L te tras de Presidente Prudente, 1972, pag. 22.
}

Ferrari Leite, José - ob. Cit. pags. 51 e 133. 
Os anos que se seguem após 1920, e mesmo pouco anterior a esta data, apresentam maior vigor quanto à ocupação e povoamento, não só no espaço em questão, mas em todo o oeste paulista.

Este período seguinte, em termos de ocupação do oeste pau lista e regiäo em estudo, é assim definido: "....Este o quadro da ocupação da ārea no início da década de 1920, ocupação essa que se aceleraria bastante a partir deste momento quando as frentes' pioneiras, avançando pelos espigões dos rios afluentes do Paraná, em direção às barrancas deste rio procuravam as terras viirgens re cobertas de mata para cultivar cada vez mais intensamente o pro duto que estava fazendo a fortuna de são Paulo: o café. Foi o café a mola impulsionadora da ocupação, do povoamento e da civi lização nesta porção do territōrio paulista, cujas cidades, em grande maioria devem sua existência, exclusivamente a ele". ( 9 )

Esta fase do processo e o movimento pioneiro, responsável pela ocupação do oeste paulista, pode ser assim sintetizada: ". ... a marcha do povoamento no Estado de. São Paulo se fez em dire ção ao oeste, quase sempre possibilitada pela cultura cafeeira, frequentemente orientada pelas ferrovias e completada pela imi gração. São as frentes pioneiras, com suas cidades cogumelos, com as pontas de trilhos a as bocas de sertão, som suas derruha das, serrarias e cafezais, com seu rápido desenvolvimento econô mico, com os grilos de terras, suas fortunas e sua instabilidade ..." ( 10$)$

Os aspectos econômicos das duas décadas seguintes - 1920 e 1930 - apresentam atividades ligadas ao povoamento mineiro e àquelas consideradas novas e motivadoras da dinâmica que se veri ficou na ocupação e povoamento.

Na década de 1920, verifica-se a introdução do café neste espaço paulista. Entretanto, áreas como as dos vales do são Ma teus e Capivara, primeiras a serem ocupadas, ainda permanecem vol tadas para a suinocultura. Nestes vales econtram-se os grandes' criadores de porcos - assim considerados aqueles que criavamentre 200 e 300 cabeças por ano - cuja grande maioria era de origem minei ra. Esta atividade permanece expressiva até 1928, decrescendo nos anos posteriores, deixando de ser comercialmente importante após 1940.

\footnotetext{
(9) - Alegra, Marcos - "0 Extremo Oeste Paulista - População" in Guia de Excursões do IQ Encontro Nacional de Geógrafos - Presidente Prudente, 1972. A.G.B. 1972 , pags. 64 e 65.

(10) - Petrone, Pasquale - "o Homem Paulista", in Boletim Paulis ta de Geografia, no 23. São Paulo, 1956, pag. 60.
} 
A expansão da cafeicultura verifica-se no final da cēcacia de 20, prosseguindo na seguinte. Na safra 1934/35 a produção de café no espaço dominacio por Conceição de Monte Alegre somou 406.658 arrobas. Entretanto, á área mais nova a oeste, sob domí nio de Presidente Prudente, produziu 1.246.324 arrobas. (tabela' 1)

Deve-se considerar, ao lado destes aspectos populacionais, que Presidente Prudente ao ser criado aumenta consideravelmente a ārea deste conjunto espacial, advindo do desmembramento das tex ras de Campos Novos do Paranapanema, principalmente da parcela' correspondente ao extremo oeste da Alta Paulista, entre o Rio do Peixe e o espigão divisor Aguapeí-Peixe. (Cartograma 3 )

o café, como em todo o oeste paulista, constitui-se, na região, como um dos principais responsāveis por este crescirento demogräfico.

Neste incremento populacional verifica-se que o imigrante, tanto nacional quanto estrangeiro, atraício pela lavoura cafceira tem papel importante.

No período 1921/34, estas duas āreas recebiam $61.62 \varepsilon$ imí grantes entre nacionais e estrangeiros. Contuda, a participação'

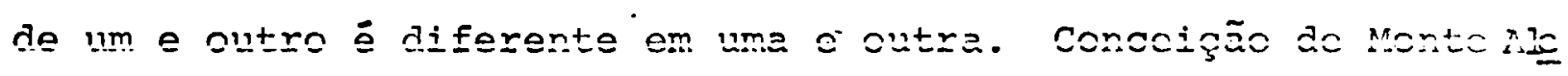
gre recebe no período 24.656 pessoas, das quais 15.243 nacionais e 9.413 estrangeiras, enquanto que a prudentina recebe 36.972 , on de os nacionais somavam 11.111 e os estrangeiros 25.814. (tabela 2)

Neste conjunto regional, clefinido após 1921, a imigração' estaria representando, em 1934, aproximadamente 33\%. Consideran do-se separadamente a área de Conceição de lionte Alegre e a de Presidente Pruciente, esta participação estaria em torno de $38 \%$ pa ra a primeira e $30 \%$ para a segunda.

Tomando-se proporcionalmente área, produção de café, e in cremento populacional, Conceição de lonte Alegre apresenta-se ao mesmo nível de Presidente Prudente, destacando-se apenas a parti cipação do imigrante que foi mais acentuada na primeira.

Entre 1934/40, verifica-se um crescimento considerável na produção de café. O espaço montealegrense apresenta em 1940 (Cen so), um total de 797.665 arrobas produzidas, enquanto que o pru dentino passa para 1.898 .665 arrobas. (tabela 1 )

Ao lado do café surge nova cultura : o algodão. Este pro duto tem o seu desenvolvimento marcado, neste extremo sudoeste 1 paulista, nos meados da década de 30 , embora viesse sendo planta do nos anos anteriores, inclusive pelos mineiros, mas sem expres 
PRODUÇÃO DE CAFE DOS MUNICIPIOS DAS REGIÖES D.3 CONCEIÇAO DE MONTE ALEGRE E PRESIDENTE PRUDENTE

(Produção em arrobas)

Tabela -1

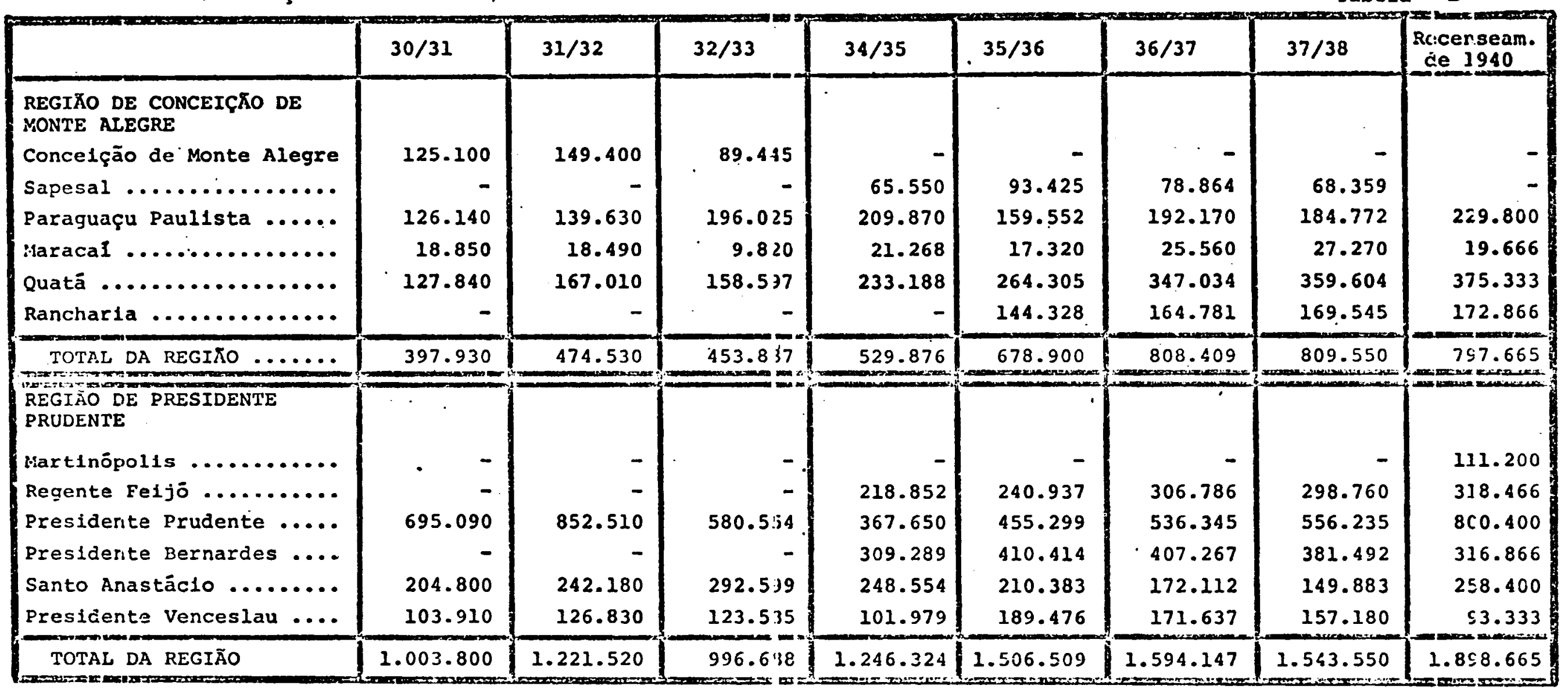

FONTES : Secretaria da Agricultura, Industria e Comércio - istatística Agricola e Zootēcn1ca (1930/39) e Censo f.gricola de 1940 .

(*) : Nas safras a part1̣̣ de 1934, Concelção de Monte Al agre tem sua sede em Sapezal. 


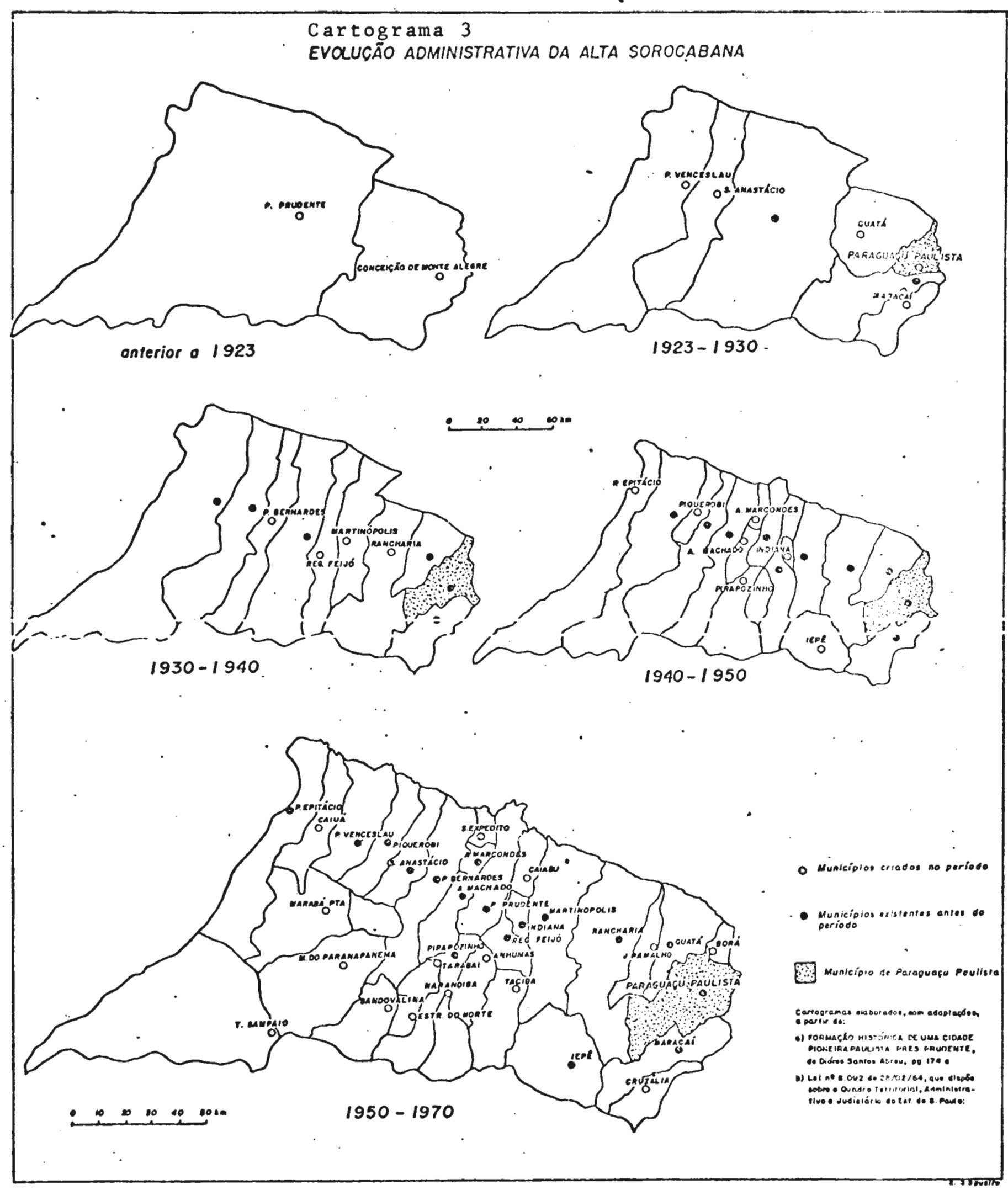


são comercial.

E a nova cultura expande-se rapidamente. Na safra 1934/35 hã uma produção de 126.293 arrobas na área de conceição de :'onte Alegre, atingindo 353.381 arrobas naquela de Presicente Pruciente. A safra 1939/40 (Censo) traz um total de 1.257 .732 arrobas e 2.765.999 arrobas, para uma e outra respectivamente. (tabela 3 )

A população total salta para 276.082 habitantes, cabencio' ao espaço dominado por Conceição 80.179 , enquanto que aquele de Presidente Prudente acomodava 195.903 pessoas.

Neste período a participação da componente imigratória é marcante no aumento da população. Os nacionais não paulistas e estrangeiros entrados nas duas áreas somaram 94.011 pessoas, o que ultrapassaria o aumento verificado em 4.637 pessoas. (tabcla 2)

Entretanto a distribuição destes recém-chegados é bastante diferente do período anterior - 1921/34. O território encal:cçacio por Presidente Prudente recebeu 66.281 imigrantes e destes 42.147 eram nacionais e 24.134 estrangeiros, enquanto que para o ricrte alegrense foram 27.730, divididos em 19.664 nacionais e 8.066 es trangeiros. (tabela 2 )

o aumento veriticacio na população, em cada uma deías, é portanto, resultante em grande parte da contribuição desta corpo nente imigratória. Entretanto, verifica-se que neste períocio há alteração desta contribuição em cada uma. đas āreas em apreço. A área prudentina, que viu sua população aumentada em 73.730 Fes soas, teve na imigração o total de 66.281 pessoas, o que nos le va a considerar que esse total imigratório contribuiu com corca de908 do aumento populacional, se não levarmos em conta as pussí veis trocas, isto é, entrada e saída de imigrantes, ocorrencio o mesmo com os naturais. Fato semelhante ocorre com a área rontea legrense, inclusive com maior enfase, já que entraram $27.730 \mathrm{imi}$ grantes, enquanto que o crescimento verificado alcança apenus o total de 15.695 pessoas.

Comparando-se estes períodos - 1921/34 e 1935/40 - pocie-se fazer algumas observaçōes preliminares.

o primeiro período apresenta um crescimento razoável da população, verificado em função de um considerável aumento do territōrio com a criação de Presidente Prudente đ̆ue, como jā se

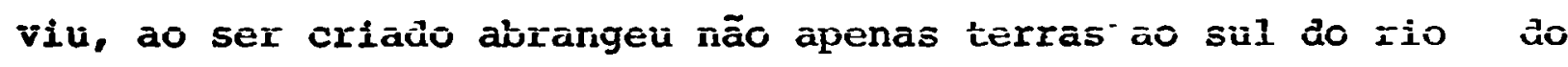
Peixe, mas, tambēm, ao norte deste; da expansão cafeeira; da Imigração e do crescimento vegetativo.

Em termos espaciais, estes fatos apresentam maior signifi 
Crescimento da População e imigrantes entrados

Ārea de Conceição de Monte Alegre e Presidente Prudente

$1921-1940$

Tabela 2

\begin{tabular}{|c|c|c|c|c|c|c|c|c|c|c|}
\hline & \multirow{2}{*}{$\begin{array}{c}\text { POPUL } \triangle \text { ÇÃO } \\
1934 \\
\end{array}$} & \multirow{2}{*}{$\frac{\text { TOTAL }}{1940}$} & \multirow{2}{*}{$\begin{array}{l}\text { Crescine } \\
\text { da popu1 } \\
1934 / 40\end{array}$} & \multicolumn{2}{|c|}{$\begin{array}{l}\text { Imigrantes nacio- } \\
\text { nais entrados }\end{array}$} & \multicolumn{2}{|c|}{$\begin{array}{l}\text { Imigrantes estran } \\
\text { geiros entrados }\end{array}$} & \multicolumn{2}{|c|}{$\begin{array}{l}\text { Total de imigrantes } \\
\text { nacion. e estrang. }\end{array}$} \\
\hline & & & & & $1921 / 34$ & $1935 / 40$ & $1921 / 34$ & $1935 / 40$ & $1921 / 34$ & $1935 / 40$ \\
\hline \multirow{6}{*}{ 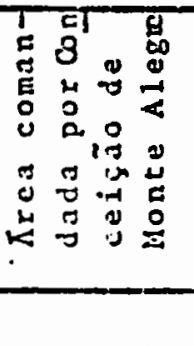 } & Sapesal........... & 20.203 & $\star \star$ & $* *-20.203$ & - & - & 1.412 & - & 1.412 & - \\
\hline & Maracaí........... & 12.940 & 14.680 & 2.740 & 1 & 77 & 896 & 936 & 897 & 1.013 \\
\hline & Paraguaçu Paulista. & 9.408 & 24.358 & $.14 .9: 50$ & 14.243 & 6.473 & 1.993 & 2.634 & 16.236 & 9.107 \\
\hline & 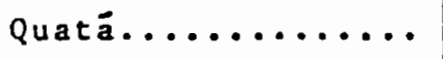 & 21.9 .33 & 20,544 & $*-1.339$ & 999 & 3.195 & 5.112 & 3.271 & 6.111 & 6.376 \\
\hline & Rancharia......... & $\star \star \star$ & 20.597 & 2.0 .517 & - & 10.009 & - & 1.225 & - & 11.234 \\
\hline & Total da área...... & 64.484 & 80.179 & $15.6 . \longdiv { 5 }$ & 15.243 & 19.664 & 9.413 & 8.066 & 24.656 & 27.730 \\
\hline \multirow{8}{*}{ 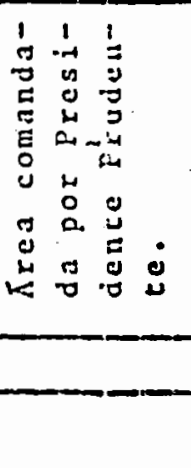 } & Presidente Prudente. & 87.442 & 75.806 & $*-11.636$ & 8.432 & 20.892 & 16.040 & 8.608 & 24.474 & 29.500 \\
\hline & Santo Anastácio.... & 19.070 & 28.290 & 9.220 & 1.181 & 5.042 & 4.563 & 4.126 & 5.744 & 9.168 \\
\hline & Presidente Venceslau & .15 .712 & 23,168 & $7.4 ; 6$ & 1.498 & 5.404 & 5.211 & 4.222 & 6.709 & 9.326 \\
\hline & Regente Feijo...... & $\star \star \star$ & 22.707 & 22.737 & - & 4.305 & - & 2.014 & - & 6.319 \\
\hline & Martinöpolis..... & $* \star *$ & 23.245 & 23.245 & - & 2.995 & - & 2.590 & - & 5.58 .5 \\
\hline & Prcsidente Bernardes & $\star \star \star \star *$ & 22.687 & 22.637 & - & 3.509 & - & 2.574 & - & 6.083 \\
\hline & Total da ärea........ & 122.224 & 195.903 & $\overline{73.6} \overline{79}$ & 11.111 & 42.147 & 25.814 & 24.134 & 36.972 & $\overline{66 .} \overline{251}$ \\
\hline & TOTAL GERAL........ & 186.708 & 276.032 & 89.374 & 26.354 & 61.811 & 35.227 & 32.200 & 61.628 & 94.011 \\
\hline
\end{tabular}

FONTE: "Crescimento da População no Estado de são Paulo e seus aspectos econômicos". José Francisco Camargo - Boletim 153, Econonia Política e llistória das Doutrinas Econônicas

obs. : * diminuição da população por perda de território, em função de desmembramentos

* Anexado a Paraguaçu Paulista

*** llunicípios criados após 19.34 
PRODUÇÃO DE ALGODÃO DOS MUNICIPIOS DAS REGIŐE!; DE CONCEIÇÃO DE MONTE ALEGRE E PRESIDENTE PRUDENTE

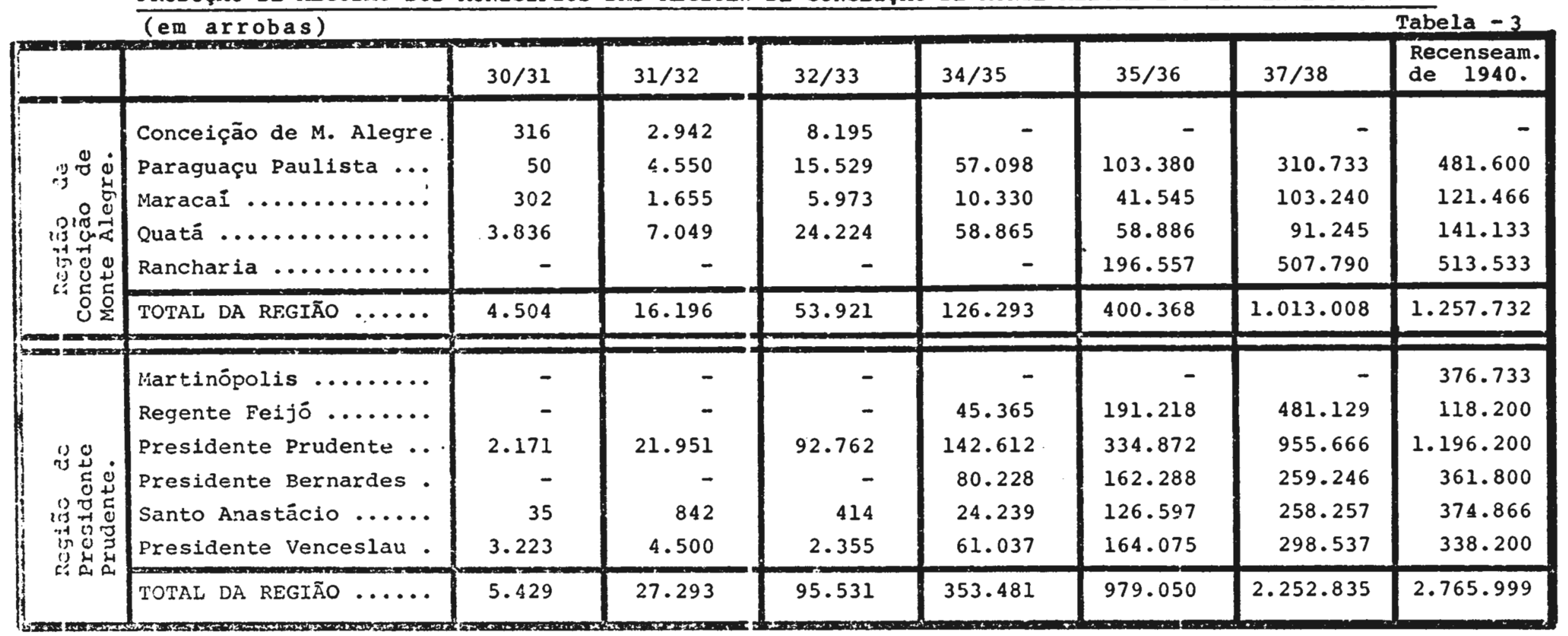

FonTES : Secretaria da Agricultura, Industria e Comércio Estatistica Agrícola e Zootécnica - J930/39.

Censo Agricola de 1940. 
cado no conjunto prudentino, exceto no tocante à imigração, cuja participação dos entrados no total da população é relativar:ente' menor que no conjunto montealegrense. O café, fator de atrạcão ' desta população, restringe sua mobilidade, tanto pelos trabalhos que a cultura exige em seu ciclo vegetativo até à produção, quan to pelas crises de ordem econômica e de clima que ocorreram em âmbito nacional e regional. ( 11 )

o segundo período traz um aumento da população e é rcsultạ do em grande parte do fluxo imigratório e da expansão de um novo produto. o espaço prudentino amplia consideravelmente a sua çea plantada, fruto, em parte, da expansão do café e principalmonte' do desenvolvimento do algodão. Conceição de Monte Alegre tambēm acompanha, em termos relativos, esta expansão, verificancio-se, en tretanto, uma queda no ritmo de crescimento da população, consi derando-se principalmente a participação do imigrante.

- café. como cultura permanente cointinua atraindo parcela' do efetivo humano, embora com menor vulto do que no primeiro pe ríodo, fixando-o por quatro ou cinco anos ou mesmo por tempo su perior. 0 algodão que se alastrara nestas regiões, abre maiores espaços a oeste $e$, por ser uma cultura que ocupa um granảe nüne ro de trabalhadores apenas uma parte do ano, no final da colheita liberava população que se dispersava procurando āreas novas e que ofeireciam maiores oportunidades. Junto à cultura cafecira ' tal fato também ocorre, figurando ao lado do oeste paulista no vas āreas de atração : Norte do Estado do Paraná e sul do Estãio do Mato Grosso.

O município de Paraguaçu Paulista no ano seguinte do da sua criação - 1925 - possuía uma população estimada em 3.526 hạ bitantes, passando para 8.702 em 1930. De acordo com o recensea mento de 1934 esta população era, no total, de 9.408 habitantes,. dos quais 6.537 na zona rural e 2.871 na urbana.

Ao seu ládo, Conceição de MOnte Alegre, que aqui scrá con siderado porque antes de findar a década de 1930 passará a intẹ grar o município de Paraguaçu Paulista, neste recenseamento de 1934 contava com 12.636 habitantes, sendo 11.962 rurais e 674 urbanos.

Portanto, ambos os municípios totalizavam 22.044 pessoas, das quais 13.499 na zona rural e 3.545 na urbana.

(11) - Abreu, DIóres Santos, ob. cit. pags. 106 e seguintes. 
No recenseamento seguinte - 1940 - agora uma única unida de politico-administretiva, mudança ocorrica em 1939, o total mu nicipal passa para 24.358 habitantes, dividicos em 19.061 rurais e 5.297 urbanos. (tabela 4 )

- fluxo imigratório até 1934 traz, para ambos os municípi os, um total de 17.648 pessoas entre nacionais e estrangeiras, ' enquanto que o crescimento natural Soma à população mais 3.066 pessoas, o que irá representar uma participação relativa, cie am bas as componentes, no total, de 93,96\%.

Entre 1935 e 1940 entram na composição da população 9.107 imigrantes e 2.209 naturais, somanco ambos, portanto, 11.316 pes soas, significando uma participação relativa de $46,46 \%$ no total populacional de 1940. (tabela 5 )

Os aspectos ligados a esta dinâmica populacional são aque les de àmbito regional.

Os primeiros cinco anos de existência do município ain ca são marcados pela presença da atividade criatória, declinarcio no final destes, ao lado da expansão da cultura cafeeira. A criação permanece nas "velhas" āreas de ocupação mineira: vales do são Mateus e Capivara.

o cafë que teve sua presença marcada nos idos de 1870 co mo tentativa (12), ocupa no município, neste periodo, o espigão divisor entre o rio do Peixe e as bacias do são Mateus e Capiva ra. Até 1929 a produção é pequena, verificada através dos ể ba $\underline{r}$ ques registrados nas estações de Sapesal, Paraguaçu Paulisti e Cardoso de Almeida, da Estrada de Ferro Sorocabana. Neste quinquê nio o total transportado a partir destas estações somou 2.360 to neladas, cabendo a maior parcela aos dois últimos anos com 1.983 toneladas, aproximadamente. (tabela 6 )

A década de 30 apresenta um crescimento na produção cafeeiro, to mancio-se esta no conjunto, até à safra de 1932/33, declinarcio a partir de então e alcançando a sua menor prođução na safra 1939\% 40. Contudo, quando considerados em separado, verifica-se ciue a produção do município montealegrense cresce até 1931/32, declinan do em seguida, apresentando como exceção a safra de 1935/36. Em Paraguaçu Paulista esta produção aumenta gradativamente atć à sa fra de 1934/35, decresce na safra seguinte, com retomada nos ancs posteriores. (tabela 1 )

o algocão, que aparece como uma produção sem expressão no

(12) - Giovannetti, Bruno. Ob. Cit., pag. 145. 
MUNICIPIO DE PARAGUAÇU PAULISTA

POPULAÇÃO URBANA E RURAL

CRESCIMENTO ABSOLUTO E PERCENTUAL VERIFICADO ENTRE 1335 e 1940

Tabela -4

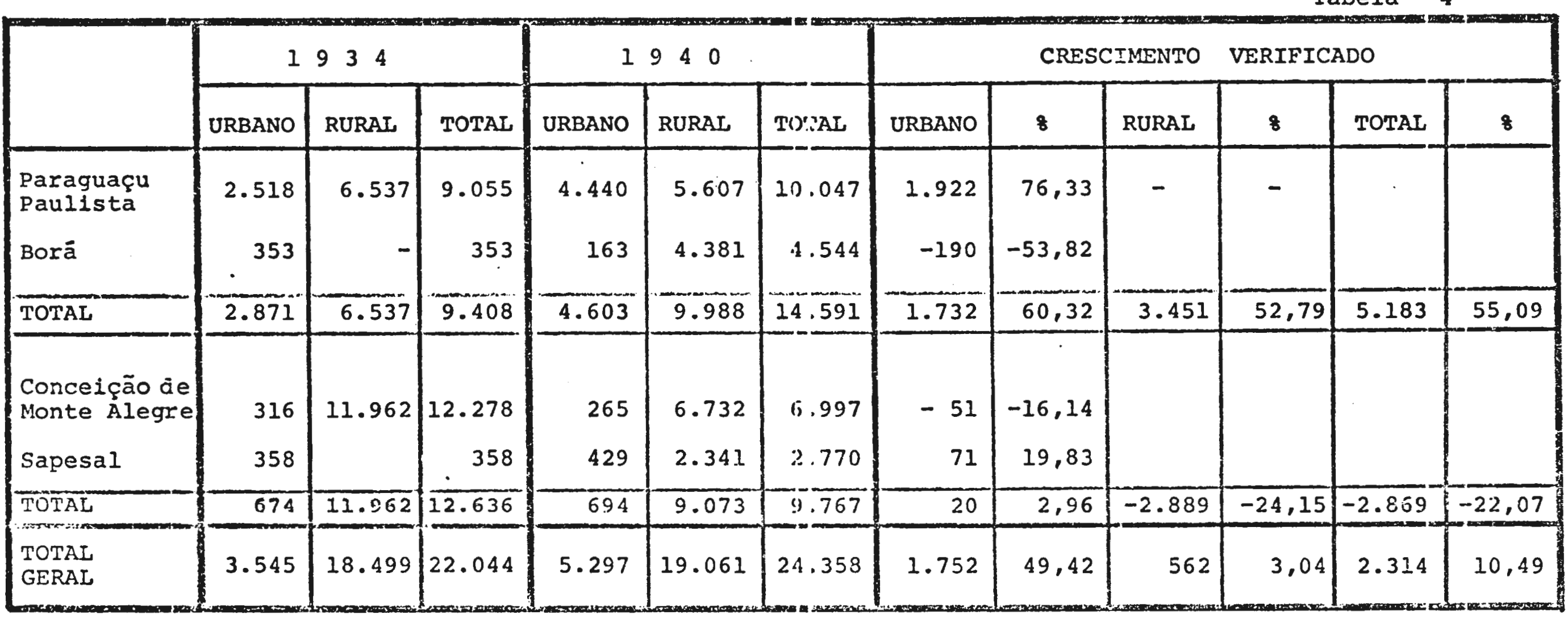

OBS : Os dados de população rural de Conceição de Monti Alegre e Sapesal foram calculados com base ras es timativas de 1935 - Archivo Püblico do Estado - utilizando-se o Indice de 28 para o crescimento.

FONTES : Recenseamento Demográfico Escolar Agrícoia e Jooiécuico - 1934.

Recenseamento Geral do Brasil - 1940. 
POPULAÇÃO - IMIGRAÇÃO NACIONAL E ESTRANGEIRA E CFESCIMENTO NATURAL SUAS PARTICIPAÇŐES NO TOTAL DA POPULAÇÃO - 1921/1.934 e 1935/1940 MUNICIPIOS DE CONCEIÇÃO DE MONTE ALEGRE E PARAGUZ.ÇU PAULISTA

Tabela -5

\begin{tabular}{|c|c|c|c|c|c|c|}
\hline & \multicolumn{2}{|c|}{$\begin{array}{l}\text { Conce lçäo de Monte } \\
\text { Alegr } \geqslant \Leftrightarrow \text { Sapesal }\end{array}$} & Paraguaç & Paulista & Ambos os & Municipios \\
\hline & $1921 / 34$ & $1935 / 40$ & $1921 / 34$ & $1935 / 40$ & $1921 / 34$ & $1935 / 40$ \\
\hline $\begin{array}{l}\text { Imigração Nacional e Estrangeira } \\
\text { Crescimento Natural }\end{array}$ & $\begin{array}{l}1.412 \\
2.017\end{array}$ & $\begin{array}{r}- \\
740\end{array}$ & $\begin{array}{r}16.236 \\
1.049\end{array}$ & $\begin{array}{l}9.107 \\
1.469\end{array}$ & $\begin{array}{r}17.648 \\
3.066\end{array}$ & $\begin{array}{l}9.107 \\
2.209\end{array}$ \\
\hline Total (Imigração + Crescimento Natural) & 3.429 & 740 & 17.285 & 10.576 & 20.714 & .11 .316 \\
\hline Total da População (*) & 12.636 & 9.767 & $9 \cdot 40.8$ & 14.591 & 22.044 & 24.358 \\
\hline $\begin{array}{l}\text { \& de participação da imigração e crescimento } \\
\text { natural no total da população. }\end{array}$ & 27,14 & 7,58 & 183,73 & 72,48 & 93,96 & 45,46 \\
\hline
\end{tabular}

(*) - Os totals de população considerados, referem-se a cada censo - 1934 e 1940.

FONTE :-José Francisco de Camargo - "Crescimento da Polulação ro Estado de são Paulo e seus aspečos Eco nônicos" - Boletim 153 - Economia Política e Históría das Doutrinas Econômicas - Usp - 19.j2.

-Anuárlos Estatisticos do Estado de são Paulo - Archivo pūblico do Estado - Recensearnertio Ẽe 1934. 
CAFE TRANSPORTADO PELA ESTRADA DE FERRO :3OROCABANA À PARTIR DAS ESTAÇÕES DE PARAGUAÇU PAULISTA, CARDOSO DE ALMEIDA E SiIPESAL. (em quilos)

Tabela -6

\begin{tabular}{|l|c|c|c|c|}
\hline ANOS & PARAGUAÇO PAULISTA & CARDOSO DE iLMEIDA & SAPESAL & T O T A L \\
\hline 1921 & 10.042 & 1.225 & 334 & 11.601 \\
1922 & 11.262 & 1.912 & 117 & 13.291 \\
1923 & 3.874 & 27.386 & - & 31.265 \\
1924 & 4.461 & 5.692 & 422 & 10.575 \\
1925 & 2.185 & 1.200 & 1.620 & 5.005 \\
1926 & 795 & 120 & 26.857 & 27.772 \\
1927 & 274.011 & 120 & 60.883 & 335.014 \\
1928 & 772.693 & 180 & 342.405 & 1.165 .278 \\
1929 & 702.311 & - & 115.797 & 818.108 \\
\hline TOTAL & 1.781 .634 & 37.835 & 548.435 & 2.367 .909 \\
\hline
\end{tabular}

FONTE: Relatörios da Estrada de Ferro Sorcicabana 
Iníclo da década de 30 , tem a sua expansão marcada a partir da safra 1934/35. O seu desenvolvimento é bastante rápido, pois de apenas 57.000 toneladas produzidas naquela safra, passa para 481 mil em 1940. Este crescimento prossegue e embora não se tenha da dos, informações obtidas dão os anos seguintes, até meados da dé cada de 1940, como os melhores de produção da malvācea no municí pio.

Considerando-se a população total verifica-se que hã o au mento total de 10,498. Entretanto, o total rural tem aumento de apenas 3,048, enquanto que no urbano este é de 49,428 , entre 1934 e 1940 .

Em separado, a unidade paraguaçuense apresenta aumento de 55,098 no total, enquanto que Conceição diminui em 22,078. Parti cularizados estes fatos, tem-se o aumento de 60,328 na urbana e 52,798 na rural de Paraguaçu Paulista e 2,698 na urbana e menos 24,158 na rural de Conceição. (Tabela 4)

Portanto, o aumento verificado no conjunto populacional, faz-se em função da unidade paraguaçuense e com maior expressão na zona urbana. A zona rural, no seu conjunto, consitui-se no elemento do espaço municipal onde se realizam os movimentos de

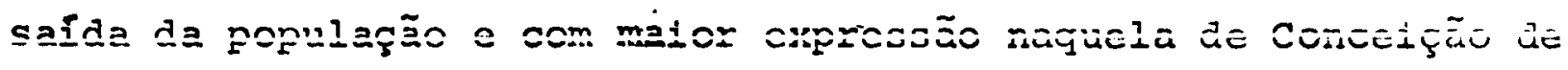
Monte Alegre. 


\section{Capítulo 3:- AS FUNÇŌES URBANAS}

3.1. Evolução das Funções

3.2. As Funções Atuais

3.2.1. A Função "Industrial": Coteta, Beneficiamento e Expediçäo de Produtos Primários

3.2.1.1. Origem dos Capitiis

3.2.1.2. Controle e Gestão

3.2.1.j3. Matéria-Prima

3.2.1.4. Produção e Mercado Consumidor

3.2.2. A Funçã்o de Distribuição de Produtos Industriais e Agy irios

3.2.2.1. nrigem dns canikie

3.2.2.2. Controle e Gestão

3.2.2:3. Abastecimento do C으 mércio

3.2.2.4. Mercado Consumidon:

3.2.3. A Função de Serviços

3.2.3.1. A Função Bancárìi

3.2.3.2. A Função Educacional

3.2.3.3. A Função Médico-Hos pitalar.

3.2.3.4. A Função Políticci.ia ministrativa

3.2.3.5. A Função de Tran:portes

3.2.4. A Função de Residência de pro prietários e Assalariados Rurais

3.2.4.1. Os proprietários lurais

3.2.4.2. O Assalariado Rusal 


\section{AS FUNÇÕES URBANAS}

\subsection{Evolução das Funçōes}

Atē meados da década de 1910, toda vica de relações cra co mandada pelo núcleo de Conceição de lonte Alegre, único centro ur bano existente no extremo oeste paulista,

Por volta de 1915/16, foram feitas as primeiras aquisições de lotes de terras no local onde surgiria a cidade de paraşuaçu ' Paulista, fruto do estabelecimento da pequena estação que a Estra da ce Ferro Sorocabana ali definira, e da ação cio proprietário de parcela da Fazenda 3 Barras, abrindo as primeiras ruas e cuadras como se verá mais adiante (capítulo 5).'.

Ao final da década de 1920, o pequeno núcleo paragiaçuense, jā sede do município, expandira -se; embora lentamente, $e j \bar{c}$ exer cia a sua influência na zona rural próxima, constituinào-sc no cen tro de coleta, beneficiamento e comercialização dos produtos rura is, ao lado de atividades de abastecimento e prestação de scrviços voltados tanto à população rural quanto à sua pequena população ur bana.

A função comercial exercia-se atravēs da comercializậ̃o ' dos produtos rurais, principalnente porcos, madeira e café, que de certa forma eram coletados e beneficiados no centro urbano, ex ceção aos porcos que eram comercializados em pé.

os suínos eram coletados e comercializacios na cidaci onde os compraciores locais, intermediärios ou representantes de fir mas do município de são Paulo (Osasco), Sorocaba e Botucatu, tra tavan diretamente com o produtor e após a transação recolhiăm os animais nos grandes mangueirōes para posterior remessa que era fei ta pela estrada de ferro.

A madeira era comercializada entre os proprictārios rurais e a serraria ou com os prepostos desta : os madereiros. o mais comum era venderem-se as matas, das quais retiravam as madeiras ce lei, que apōs beneficiadas nas serrarias eram remetidas, eli gran de parte, para a ciciade de são paulo.

A comercialização do café fazia-se diretamente entre o fa zendeiro ou produtor e o beneficiador que posteriormente o remetia, via estrada de ferro, a Santos, às casas Comissárias que o ceposi tava e negociava. Embora raros, havia fazendéiros que mantinham' contatos e expedição direta para Santos, antes porém, efetuando o benefociamento em Paraguaçu.

Como centro de abastecimento, o comércio atendia às ncces 
sidades bāsicas da população urbana e rural próximas, sendo o aten dimento a esta ültima limitado, caracterizando-se principalrente pelo fornecimento de querosene, sal, farinha de trigo, açúcar , calçados rústicos, ferramentas e remédios.

Este tipo de consumo caracteriza na época a presença clas lojas ou armazéns, onde se encontrava os mais variados produtos: secos e molhados, tecidos, calçados, ferramentas, etc..

A este quadro da função comercial ajuntavam-se, embcra com atendimento mais urbano, os açougues, os bares e farmácias.

o aprovisionamento destas casas comerciais fazia-se atra vés da presença dos caixeiros-viajantes do atacado ou incústrias, provenientes, na sua maioria de são Paulo, Sorocaba e Botucítu.

Os serviços assinalavam-se pela presença de hotéis $e$ pen sões, salões de barbeiro, cinemas, escola, ao lado dos serviços' públicos: administração pública local, coletoria estadual, corre io e cartórios:

Os hotéis e pensões voltavam-se principalmente aos cai xeiros-viajantes, àqueles que demanciavan à região para compras de terras ou negócios ligados à produção rural e em casos menos fre quentes, aos proprietários e trabalhacóres-rurais que para seus

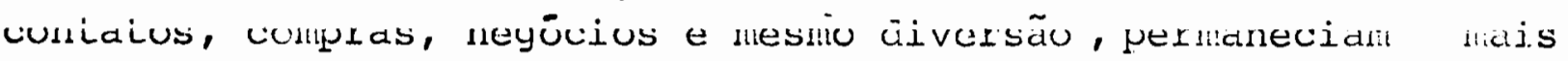
de um dia na cidade. Por fim, constituíam na "pousada" para aque les que provinham ou dirigiarn-se à zona rural, Conceição de lon te Alegre e núcleos vizinhos, utilizando-se da estrada de ferro como meio de transporte.

os demais serviços voltavam-se quase que essencialmcnte' ao núcleo urbano, exceto os aciministrativos públicos, cuja influ ência alcançava os linittes de sua jurisdição, comumente munjicipa is.

A função industrial estava representada pelas serrariás ,. unidades de beneficiamento de café e arroz, cuja matéria prira ' era fornecida pela zona rural próxima, destinando-se o prociuto beneficiado a um mercado distante : são Paulo e Santos; pclos ar tesanatos - selarias, sapatarias, funilarias -, voltados ao mer cado urbano local e à zona rural próxima; pelas indústrias ali menticias - padarias - sendo estas de consumo quase que exclusivamente urbano. Como fato excepcional havia a presença de uma tí pografia.

A pequena cxpressão do mcrcado local o da produção rural, justificados pelo início da fase cafecira, conseqüentemente da abertura e desmatamento de novas áreas, restringe a ativicacic in dustrial a poucos estabelecimentos, cuja influência limita-se ao 
pequeno centro e à áreai rural próxima.

A disposição destas diferentes atividades no quadro inicial da cidade pode ser apreendida através da planta 6 ,pág. 186 :

A fase seguinte, ou seja, entre o início da década de 1930 até meados dá década de 1940, apresenta modificações na economia rural, refletindo-se nas funções tanto nas suas composições quan to no espaço de atuação destas.

- café continua desenvolvendo-se até o início da década de 1940, declinando paulatinamente a partir de então. A seu laco, a partir de meacos da década de 1930, surge a cultura do alçodão, que se expande rapidamente, alcançando o apogeu nos primeiros a nos do decênio seguinte. Paralelamente, a madeira continua sendo explorada à medida que estas culturas avançam para novas terras, enquanto que a atividade criatória dos sú́nos, face ao valor eco nômico que os novos empreendimentos agrícolas trazem e à concor rência dos centros criadores do sul do país, perde a sua expres são.

Do ponto de vista populacional verifica-se grande mobilida de, sendo que a zona rural constitui o palco das maiores r:ovimen tações, constituindo a cidade elemento onde a presença do homem' é mais estéryel.

Os novos trabalhadores e ocupantes das terras rurais e da cidade deixam de ser os mineiros, que até então haviam sido os po voadores, substituídos pelas levas de imigrantes nacionais e es trangeiros, destacando-se o nordestino, italiano e japonês.

Antes de considerar-se as mudanças ocorridas nas funções,' deve-se ter em conta a presença e o desenvolvinento do transporte rodoviārio.

Este meio de transporte, através da sua flexibiliciacic e re lativa rapidez, possibilitou a ocupação e exploração de āreas mais afastadas. A presença do homem e das produções mais distan tes, no centro urbano, foram facilitadas através do caminhão, dạ "jardineira", automóvel, uma vez que antes do seu advento utili zava -se os veículos de tração animal ou os próprios animais.

o novo meio de transporte naõ se apresenta como concorrente, nesta fase, à estrada de ferro, mas como um complemento desta que permanece como meio de transporte para exportação e importação dos produtos industrializados ou beneficiados edos homens que se dirí gem aos centros mais importantes e distantes ou que deles provém.

As funções crescem pelo dinamismo que o centro urbano apre senta, primordialmente fruto da intensa atividade que a cultura algodocira gera na região. 
- comércio amplia-se consideravelmente, contando em meio a esta fase (1938) com mais de uma centena de estabelecimentos,' predominando os bares, secos e molhados, tecidos e armarinhos, a çougues e calçados.

Sua ação não se diferencia em muito daquela da fase ini cial. Os rurais continuam a duslocar-se nos fins de semana, início ou final da safra atē aos armazéns, lojas, etc.,abastecendo-se do essencial, acrescentando-se ao conjunto o necessārio à manutenção dos veículos, o que justifica na cidade a presença das agêricias e oficinas de automóveis e postos de gasolina.

As relações entre o comerciante e o trabalhador rural tor nam-se mais intensas. A época cie duração de cada safra, diferentes no decorrer do ano para caảa produto, as formas de pagamento pe los trabalhos ou produção, seja através ce salārios, financiamen to das lavouras ou a espera da comercialização final desta, deter minam o abastecimento do homem rural através de créditos concedi dos pelo comerciante. Este crédito era obtido pelo confecimento que o comerciante possuía daqueles a quem servia ou através da prē-ceterminação de casas comerciais por parte do proprietūrio ru ral ou financiador da lavoura, para as compras, caracterizincio, de maneira geral, o "fornecimento" normalmente liquidável ao final. de cada safra.

Os serviços descnvolvem-se razoavelmente, não só amililianào as suas atividades bem como sua ārea de influência. Esta expansão é caracterizada não apenas pelas atividades de atendinento dirigi do ao centro urbano, mas principalmente voltado a uma clientela' da ārea rural próxima. Entre aquelas atividades de característi cas mais urbanas, havia nesta fase, a predominância dos conscrtos em geral e tinturarias. O atendimento externo estava representado em maior grau pelas pensōes e hotēis, que continuam com as niesmas caracteristicas, agora mais numerosos(aproximadamente 20 estabele cimentos) e voltados principalmente ao atendimento de pessoas li gadas ao comércio.

Complementando o atendimento externo há a atividade bancā ria, que surge com seis estabelecimentos, ocorrendo a implantação deste serviço entre 1937 e 1942, sendo um deles de origem local.

o primeiro estabelecimento bancārio é de iniciativa local através da instalação da Casa Bancāria que se constitui corres pondente de organismos financeiros localizadoṣ em cidades vizi nhas ou distantes e de maior porte. ( 13 )

(13) A casa Bancária Manilio Gobbi representava o Banco ÍtaloBelga, agência de Botucatu; Banco Francês-Italiano;Banco Íta lo-Brasileiro, agência de Ourinhos; Banco Comercial co Estā do de $\mathrm{S}$ ao Paulo, agência de Assis. 
Esta iniciativa tem suas origens vinculadas aos financiamentos que seu proprietārio - fazendeiro de café, comerciante e beneficiador - concedia aos proprietários rurais entre e durante as safras (entre os fins da década de 1920 até meados da seçuintel

Posteriormente, com o crescimento da atividade, instalou escritório, que ao lado do atendimento de seus interesses,passa a efetuar cobranças para os diferentes estabelecimentos bancários citacios. Em 1937, como representante daqueles, transforma-se em Casa Bancária Manilio Gobbi, culminando com a instalação ce sua própria agência (1942 - Banco de Crédito Manilio Gobbi) que che gou a possuir filial no vizinho município de Iepè (1954).

Após a Casa Bancária Manilio Gobbi, instalam-se na ciciacie a Caixa Econômica do Estado de são Paulo (1937), a Casa Bancária Bratac (1939) que em fins de 1940 é absorvida pelo Banco Ariérica do Sul; as agências dos Bancos Ítalo-Brasileiro (1939), Comercial do Estado de são Paulo (1940) e Banco do.Brasil (1940).

Esta função financeira, reflexo da expansão comercial $e$ in dustrial marcada pelo desenvolvimento do algocião, pela frescnça,inclusive do Banco Oficial àe âmbito nacional (Banco do Brasil), não se restringe aos limites municipais, drenanco ārea corıiciarā-

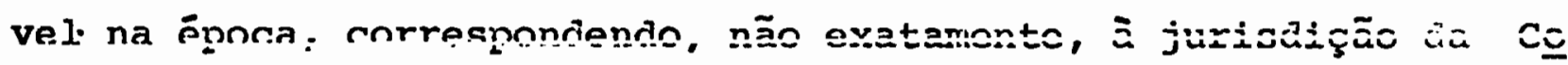
marca: Rancharia, João Ramalho, Quatá, Borā, Lutécia, Oscar Bres sane, Cọnceição de Monte Alegre, Maracaí, Iepê, Cruzālia.

Ainda nesta fase instalan-se na cicade: hospital, ginásio, grupo escolar - este complementando a atividade já existente na década anterior com algumas classes de curso primário - quatro mé dicos, cinco dentistas, cinco advogados e un engenheiro civii.

Estes serviços, no início, voltam-se ao atendimento local e ao espaço rural próximo. Entretanto, alguns anos após, suã área de influência aumenta consideravelmente, destacanco-se c ätendi mento médico-hospitalar, face ao seu melhor equipamento, e o ensi no de nível ginasial.

o hospital no ano seguinte ao de sua instalação (194\%,tcm $80 \%$ do seu atendimento voltado à cidade e à zona rural do nunicí pio, 17,5\% ao espaço próximo, em um ráio de aproximadamente $50 \mathrm{~km}$

O ginásio, nascico da iniciativa particular (1943) e cairí gido por grupo religioso'de origem estadunidense sediado en La vras (MG), atende nos seus primeiros anos apenas à localiclate e área bem próxima. Após a instalação do internato (1945), a sila área de ação é veriflcada em toda a Alta Sorocabana.

A função industrial marca sua presença na cidade, princ1 palmente face ao desenvolvimento do algodão. O novo produto traz 
para o centro urbano a indústria a ele diretamente ligada: as $\underline{u}$ sinas de beneficiamento, culminando ao final da década de 1940 com a instalação da fábrica de óleos vegetais.

Estas atividades têm suas origens na iniciativa local. a través da impilantação, entre 1934/35, de duas usinas de benefí ciamento.

A primeira delas, de origem local, resultou da composição de sociedade - Algodoeira Paraguaçu - entre A. Magnanelli, zanca ner e Cia. Pagano e Cia. (14) . o surgimento da indústria e so ciedade foi fruto dos contatos e entenaimentos existentes entre os diferentes sócios quando da conercialização do caré,tanto em são Paulo, quanto en Santos, e do interesse comum despertacio pe lo novo proảuto que começava a expandir-se na Alta Sorocatana, ao lado do caré.

A segunda usina instalada na cidade constitui filial de inaústria dó algodão com matriz em Avarẹ: Nicanor Garcia \& Cia. Benefício de Algodão. A sua presença em Paraguaçu Paulista $\bar{c}$ re sultante da preocupação do beneficiador do produto em colccir-se próximo às novas áreas de cultivo, onde as perspectivas de procuu ção eram promissorás. Nos anos que se seguem à sua instalaçio, a filial passa a constituir-se na principal fonte de rendas da $\underline{\text { r }}$ ganização.

Entretanto, ambas, pequenas indústrias, tèm curta dura ção, cedenco lugar às firmas de maior porte que passam a irista lar-se na cidacie. Este aspecto não constitui fato peculiar a Pa raguaçu Paulista, ocorrenco, tambēm, em Rancharia,Presiciento Pru aente, onde as pequenas incústrias do algocão deixam de existir pelo mesmo processo.

Em fins da década de 30, início dos anos 40, a expansão e valorização regional co produto atrai firmas de ânbito initerna cional, nacional e estadual: Anderson \& Clayton (1939), Mac Fad den (1940), SAINBRA (1942), SAAD (1945. A primeira delas rira-se' adquirindo as instalações da Algodoeira Paraguaçu, para, poste riormente, adquirir ārea razoāvel onde monta a fábrica de óleos vegetais.

(14) - A.Magnanelli - antes da instalação da hlgodoeira cxorcia em Paraguaçu paulista as atividades de fazendeiro íc ca fé, comcrciante de café, cereais, rnacieira e beneficizicor cee café e arroz. Com a organização da scciedacie permancé , paralelamente, apenas com a fazenda de café.

Zancaner \& Cia - proprietśrio de farcnda de café no into rior paulista e exportacior do produto.Suas ativicicies es tavan vinculacas à capital paulista e Santos.

Pagano \& Cia - proprictário de fazenda cafeicultora no interior paulista, comerciante de cereais na capital. pau lista e exportador de café. 
A Mac Fadden arrenda as instalaçöes de Nicanor Garcia, sen do o seu furcionamento efêmero - apenas una safra. As cicnais constroen e montam suas instalaçōes industriais.

Além da atividade algodoeira, a função incustrial lig̣aãa à produção rural, conta com beneficiadoras de arroz, café $€$ ser rarias, ressaltando-se que parte delas surgiram na primeira fa se.

A partir dos fins da década de 1940 ao final dos anos 60, verifica-se a presença mais acentuada do gado como principa] pro duto econômico, daỉ a grande expansão das pastagens, ao lặo do declínio do café e algoaão.

Tomando-se os dados do censo, o café apresenta poriuna çueda na produção em 1950 e discreta elevação em 1960. Contucio,a partir de então, adquire acentuada decadēncia, refletiāa na: pro cuução de 1970: 35.000 arrobas. O seu deciñnio, em temos gorais, ocorreu por ter oclipado os solos não muito férteis e de rápicio esgotamento (arenosos), à não reposição da cultura atravēsi le no vos cafejeiros, à concorrēncia do algoaão e à expansão das rovas áreas cafeeiras, principalriente do Norte do Paraná.

o algodão apresenta as mesmas caracteríticas: ajos acon tuada queda de produção observada entre 1940/50, cstabilizi-.se entre 1950/60. A partir de 1960 o declínio acentia-se novar conte, mostrando os dados de 1970 uma produção eçuivalente à metacie dạ quela de 1960. O uso inadequado do solo, a aplicação de técnicas que acarretaram o seu esgotamento rápido, constituíran as cuusas fundamentais da ciueda de produtividace e perda de expressão do produto. A estes fatos somam-se a ocorrência sucessiva de rragas que além de influir na prociução, acarreta gastos considerävcis em inseticidas e defensivos; os preços mínimos ditados por merca do interno afetado pelas cotaçc̃es internacionais, são cesajienta dores, não cobrincio suficientemente os custos de produção, jeran do nas safras un verdadeiro leilão do proüucio. A estes fatos jun te-se, finalmente, a concorrência das fibras artificiais.

Ao lado das oscilações e retraimente destes produtos, o rebanho bovino e as pastagens expandem-se, apresentancio no perío do 1950/60 o seu maior desenvolvimento. Esta atividade clesonvolve-se rapidamente incentivada pelos mercacos consumicores urba nos distantes, pelos financiamontos facilitados por órgãos of ciais (Banco do Bīasili), ocupancio árcas de cerracios, matas ov a quelas liberadas pelo retraimento das culturas do café e alcodão. Estas oscilações e mudanças na economia municipal são se guidas de mudanças ocupacionais. As culturas entrando em declí 
nio liberam mão-ce-obra rural que não é absorvida pela ativiclade pastoril, que a utiliza em número recuzido, ciefinem a queda do fetivo populacional rural que se dirige para novas áreas rurais ou para os centros urbanos, fato mais caracterizado em parasuaçli Paulista duránte a década de 1950 (cap..4, tabela 17 ).

Estes fatos econônicos e populacionais refletem-se nas fun çõès urbanas paraguaçuenses, principalmente após 1950 ao final da décađa de 1960.

A atividade comercial altera pouco a súa composição, jerma necendo com o predominio dos secos e molhados, tecicos, calcacios, açougues e bares. Observa-se que em alguns ränos da atividace são acrescentacios estabelecimentos de origem local ou filiais de orga nizações presentes em outras áreas do Estacio, mas que duram pou co, encerranco suas ativiciades principalmente na cécacia de 1060 . (15).

A. função permanece atenciendo a ciciade e áreas próximas, rias sua influência deixa de voltar-se externamente ao raio e forca ' que alcànçara na fase anterior, passando a ter maior express̃o no mercado urbano, mais significativo e desenvolvido nos anos cic 50 , arrefecendo e entrando em processo do esvaziamento a partir de 1960, décacia que assinala certo marasmo na cicade.

Os serviços igualmente são afetados. No conjunto a função volia-se primordialmente ao centro urbano, cabendo a alcurs seto res da atividade a presença no espaço próximo, que se reciuzira sensivelmente em relação ao período anterior.

As naiores alterações ocorren nas funções bancárias, educa cionais, médico-hospitalares, administrativas - estadual e runici pal.

A função bancária - com seis estabelecimentos na faso ante rior - ao final do decênio de 1960 apresenta cinco, dos quicis trés são oficiais. A prineira vista sente-se pouco a modificação. Mntre tanto, estabelecirentos desaparecem e outros surgem, desionsirancio a instabiliciade do setor.

A Casa Bancāria Bratac, ligada à presença dos japonesses na região, transforma-se, como foi visto, na agência do Banco Améri ca do Sul, que em meio à década de 1950 encerra suas atividacies ' em Paraguaçu Paulista.

(15) Como exemplo, as filiais de loja de tecidos: Riachuelo i nicia suas atividades em 1952, encerrando-as em 1963; Ja raguá inicia em 1957/58, encerrando em 1963; Buri ini ciou em 1965, encerrando em 1969.Como empreendimentos lo cais sob este aspecto há principalmente secos e nolhados. 
A iniciativa local, que se desenvolvera rapidariente, pōe fim às suas atividades por volta de 1957/58, apōs sērias dificul dades.

Neste mesmo período, instala-se na cidade o Banco Indus trial de São Paulo (1955) que posteriormente passa a ser o ianco Econônico da Bahia, cuja agência funciona até 1969, quando : õe ' termo às suas atividades.

o Banco do Estado de São Paulo, instalado em 1967, coristí tui a mais recente agência bancária da ciadade.

Alén deste, o Lanco do Erasil, Caixa Econônica Estaciual, Banco Comercial de são Paulo e Banco Brasileiro de Descontoe, sub sistiram, embora estes dois últimos tenham apresentacio sucessi vas incorporações, com conseqüente mudarças de denominações nos últimos anos.

A função bancária que tivera atuação em espaço rázcável restringe-se a uma presença de âmbito nunicipal, exceção ao Ban co do Brasil, cuja jurisdição extravasa os linites äa Comasca. (16).

A função ecucacional recebe o Gināsio Estadual de Purag̣ua çu Paulista, en 1949. Este estabelctimento de ensino passa a con tar, em 1950, com Curso Nomal e em 1956 cori Curso Colegia, fun cionando, após 1960, os cursos noturnos.

Ao lado, o Ginásio Paraguaçu, priṇeiro da estrutura iciuca cional da cidacie, instala em 1957 os Cursos Básico Comerciai e Técnico Comercial, também com cursos notiurnos.

Além destes estabelecimentos de segundo ciclo a cidacie re cebe aqueles ligados ao ensino primário, passando a contar cori dois grupos escolares e um curso primārio anexo ào curso nomal.

A zona rural igualmente é beneficiciảa com inúmeras clas ses deste nível de ensino.

Esta função continua atraindo e servindo não só o runictẹ pio e āreas vizinhas, nas, tambēm, alcançando toda a Alta sorca bana e algumas áreas do sul de Mato Grosso (Douracos), principal mente com o ensino particular através de seu internato. Entrctan to, à medida que o ensino oficial expanāe sua rede pelo Estaco,a quela ativiciale perde seu valor recional, voltancio-se quasc que essencialmente ao centro urbano. O ensino particular fica restri to ao colegial comercial desaparecendo seu internato, apesar dás tentativas e investimentos feitos para mantê-lo.

(16) A comarca nesta fase perde Rancharia que passa a ser Co marca,envolvendo Iepê, Quatá, que também constitui sede de Comarca, envolvendo João Ramalho. 
A função méaiico-hospitalar modifica-se tanto quanto à pre sença de estabelecimentos hospitalares, como ao seu corpo médico.

Ao final da década de 1940, início dos anos 50, além da am pliação das instalações e equipamentos do Hospital de Caridace, a cidade passa a contar com mais uma unidade hospitalar - Casa de Saúde Santa Inès. Nesta mesma época o corpo médico era constituŕ do por oito profissionais, sendo três de clínica geral e os de mais distribuídos pelas especialidades de otorrinolaringologia,' oftalmologia, pediatria e radiologia.

No decorrer das cécadas que se seguem $(1950 / 60)$ hã altera ções na função. A Casa de Saúde santa Inês desaparece no primeiro Iastro da década de 1960, havendo uma compensação com a instala ção do Centro de Saúde e Posto de Puericultura, embora o primeiro já existisse desde 1942 como Posto de Higiene, alguns anos mais tarde transformado em Posto de Saúde.

o corpo médico se vê modificado e substituído continuamen te, para após 1965 contar com apenas um pediatra e um radiologis ta em termos de especialização, sendo os cinco demais de clínica geral.

Embora a função apresente estas varịações a sua atuação e influēncia permanece pouco mais intensa: embora alcanranca a mes ma região do periodo anterior. Estes aspectos podem ser constata cos pelo atenciimento do Hospital de Caridade em 1961 : ' aten dimento de pacientes locais (urbanos) : 45,58; atencimento a pa cientes da zona rural do município :13,5\%; atendimento a pacien tes da região próxima, outros municípios, que constituè os mes mos de $1948,33,6 \%$.

Quanto à função administrativa, hā que se considerar dois niveis: estadual e municipal.

Ao nivel estacual, a função administrativa alén daquelas existentes e ligadas às diferentes Secretarias de Estacio ( Saūde, Educação, Fazenda, etc) jā existentes na cidade e em parte consi deradas, tem no setor voltado à agricultura a presença de duas a tividades que passam a agir no meio rural através de orientação técnica e preparo de sementes e mudas: a Casa da Agricultura, que se constitui posteriormente em Delegacia Agrícola e o Posto de Se mentes e mudas.

Ressalta-se estes aspectos, porque a partir de Paraguaçu Paulistá, atravēs destes órgãos, è que se farā a oricntação e o fornecimento de sementes adequadas e de qualidade a uma região ' bastante ampla, atingindo aproximadamente 30 municípios no que diz respeito ao Posto de Sementes. 
Ao nível municipal, a função administrativa volta-se neste período à cldade dotando-a de uma série de serviços públicos que serão objeto de anālise no capítulo 5 ..

Os demais serviços permanecem, com pouquíssimas diferenças ao nível do período anterior (1930 a aproximadamente 1945), volta dos na fase em foco, a um atendimento mais urbano.

A função industrial que se expandira alicerçada na cultura algodoeirá, também altera-se. O beneficiamento da madeira resiste até o desaparecimento total das matas na região próxima e distan te, chegando a receber madeira do Estado de Mato Grosso. 0 encer ramento desta atividade ocorre nas duas primeiras serrarias da ci dade por volta de 1957 e 1968. Contudo, a atlvidade ainda é repre sentada por uma serraria de pequeno porte instalada em 1970, cujo atendimento è essencialmente local.

Ao lado deste beneficiamento surgem as indústrias do mobí liário, cujo abastecimento e consumo são, em ambos os casos, exter nos e desvinculados do beneficiamento, como se verá mais adiante, que implantadas nesta fase desenvolveram-se rapidamente abastecen do toda região, alcançando, em determinados produtos, a capital ' paulista.

A indîstria algodreitra intrialmente, ni seja; na dềracha de 1950, permanece no mesmo estágio, mas não à custa da produção - lo cal e área próxima, mas sim regional, buscando o produto no norte do Paraná e Alta Sorocabana, através de compras diretas ou trans ferências por parte das filiais ou postos de compras das firmas.

A fábrica de óleos vegetais recebe o caroço do algođão de vărias usinas de beneficiamento que a Anderson clayton possui na Alta Sorocabana e pequena parcela daquela local.

Ao final da década de 1960 a SANBRA já havia encerrado as suas atividades de beneficiamento (1967). A Anderson clayton 1 gualmente caminha para o mesmo processo, restando a sua fábrica de óleos, que ao longo destes anos procura outros produtos( amen dolm, soja), para extração do óleo e subprodutos, ao lado da preo cupação em diminuir a ociosidade da inđústria.

Outras atividades surgem e desaparecem neste período, de monstrando a pequena importância do mercado local e fragilidade das forças de produção, principalmente capital, mão-de-obra espe clalizada e equipamento, à concorrência de outros centros indus triais. Como exemplo temos a indūstria química (cera, sabões, ve las, perfunaria) que de quatro unidades industriais instaladas na cldade, subsistiu apenas uma.

Aquelas que surgem e permanecem, mais antigas, dēcada de 
1950 ou mais recentes - final da década de $1960^{\circ}$-, são. pequenas, na maioria de base agrícola, com concorrência menos intensa, de consumo imediato local e regional, destacando-se as alimentares. Neste conjunto de pequenos estabelecimentos industriais , temos: torrefação de café, beneficiamentos (arroz, cafē), fãbri cas de farinhas (milho, mandioca), fábricas de bebidas, vassouras colchoaria, carpintarias, serralheria e pequena fábrica de rou pas.

Portanto, à partir dos primeiros anos de sua existência , Paraguaçu Paulista desenvolveu funções de coleta, beneficiamento e expedição de produtos rurais, complementando as atividades agrf colas em desenvolvimento, ao lado da distribuição de gêneros e prestação de serviços.

Diretamente relacionadas e dependentes da produção agrope cuária, interessando sempre um mercado distante, as diversas ati vidades ligadas às funções cresceram ou decresceram em número , surgiram e permaneceram e, em certos casos, desapareceram, face à sucessão, desenvolvimento, decadência e desaparecimento · dos produtos rurais com peso economico.

No início, a pequena expressão da população, do mercado 1o cal e da produção rural, justificados pelo limiar da fase cafeeira não só no município mas em toda a Alta .Sorocabana, conseqüentemen te uma fase de abertura, desmatamento e ocupação de novas áreas, delinearam funções urbanas que se restringlram a poucos estabele cimentos, cuja influência limitava-se ao pequeno centro e à área rural próxima:

À partir dos meados da década de 30, momento em que ocor rem mudanças econôm1cas na região, conseqüentemente no município, com a introdução do algodão, fruto das contingências criadas em âmbito internacional e nacional pela crise de 1929, a cidade di namiza-se.

Nesta fase de predomínio do algodão ao lado do café, lá vouras altamente comercializáveis, o centro urbano paraguaçuense tem suas funções desenvolvidas, na medida em que os diferentes $\mathbf{x}$ tores atendendo às necessidades das crescentes populaçōes rural e urbana complementando. aquelas atividades agricolas, ampliam e acrescentam atividades. A sua presença que fora limitada ao cen tro local e área próxima, alcança áreas mais distantes confundin do-se, grosso modo, à jurisdição da comarca e, em alguns setores e atividades, chegando aos limites da Alta Sorocabana.

A permanência do algodão e café, contudo com produções In 
dicadoras do início de seus declínios, a expansão do gado e das pastagens constituem os fatos econômicos que se manifestam à par tir dos fins da década de 1940 aos fins dos anos 60. Estes fá tos afetaram, ao longo do periodo, a distribuição populacional e, consequientemente, as funçōes urbanas.

Durante a década de 1950, período que se caracteriza pelo equilíbrio nas produções agrícolas em questão e maior crescimento da atividade pecuária, tem-se o maior crescimento da população urbana e tambēm o maior decréscimo da rural. Nestes anos as fun ções ainda apresentam um certo dinamismo, refletido nas implanta ções de estabelecimentos comerciais, serviços (principalmente ur banos) e pequenas indústrias. A partir desta década e ao longo da que se segue (1960), o esvaziamento populacional rural não $\infty$ pensado pelo crescimento da população urbana e o declínio das produções agrỉcolas com a relativa estabilização da expansão do gado e pastagens, representam de um lado o recrudescimento do mer cado consumidor e de outro a queda no fornecimento de matérias-' primas, afetando as diferentes funções urbanás, oferecendo . como resultado a estagnação da cidade com consequiente retraimento da área sob sua influência. 
3.2.1. A Funcão "Industrial": Coleta e beneficlamento de produtos primārios

A função industrial nasceu na Alta Sorocabana à partir da dëcada de 20 , com a expansão da cultura cafeelra.

As primeiras indústrias são as serrarias, beneficiadoras de café, de arroz, sucedidas pelas de algodão (produzindo algo dão em pluma e óleos vegetals) e da carne; cujos produtos interes savam sempre um mercado extra-regional distante. Ao lado destas e visando o mercado regional e local surgem as alimentares, pe quenas manufaturas e artesanatos da madelra e do couro, farinhe ras, etc.. Com o desenvolvimento das cidades surgiram outras com plementando este segundo grupo, ou seja: torrefaçōes, fäbricas de bebidas, serralherịas, gráficas, artefatos de cimento e outras mals.

Atualmente, embora tenha decorrido mals de cinco décadas, esta orientação inicial vem permanecendo.

Segundo o Censo Industrial de são Paulo, 1970, a região da Alta Sorocabana, do município de Assis ao de Presidente Epit tá clo, apresentou uin valor total da transformação 1ndüstrlá de aproximadamente $187 \mathrm{milhöes} \mathrm{de} \mathrm{cruzeiros:} \mathrm{cahendn} \mathrm{ans} \mathrm{tep} \mathrm{minnir}$ plos de malor destaque uma participação de 93,48. (Tabèla 7) .

As atividades industxiais mals importantes neste grupo de municípios, segundo este valor da transformação industrial, es tão representadas pelas indústrias alimentares (indústrias de óleos vegetais, frigorificos, usinas açucarelras, benefícios de café, de arroz, torrefações de café), Indústrias químicas, "téx teis" (usinas de beneficlamento de algodão), da madeira (serrari= as).

Considerando-se os dez municípios mais importantes, pode-se definir um centro de destaque, representado por presidente Prudente, capital regional, centro mais populoso com atividades industrials mais expressivas; un escalão intermediärio, onde sob - aspecto populacional sobressai Assis cabendo aos demais uma cer ta Igualdade numérica. Quanto ao setor Industrial, as variaçōes ' são pequenas, mas não seguem a ordem de predominâncla popula cional. Finalmente um terceiro escalão de municípios onde os nū meros de população e os valọes apresentados pelo setor industri al são igualmente os menores da região.

comparando-se a participação dos valores da transformaçāo Industrial destes municípios, exceto Presidente Prudente, veri代 ca-se que os municíplos do leste da região têm maior expressãa. 
Rancharia e Paraguaçu Paulista distinguem-se pela presença de in dústrias téxteis e de óleos vegetais de maior porte, enquanto que Assis, maior centro urbano neste escalão intermediário, tem o seu destaque assegurado muito mais pelo número de indústrias que pe 10 porte destas, embora as mais representativas sejam o benefici amento do algodão, óleos vegetais e frigorífico de médio porte.

Os demais municípios têm menores participações. Os seus ma lores valores de transformação industrial uma vez mais são prove nientes da indústria têxtil e alimentar. Neste grupo de municípi os as indústrias alimentares são as mais expressivas e encon tram-se no oeste da região, onde as atividades mais importan tes estão ligadas à pecuāria: frigoríficos, curtumes, laticínios. Como exceção temos o.município de Presidente Epitācio, cuja ati vidade industrial ligada ao beneficiamento da madeira constitui' aquela de maior expressão, não só neste, mas para tōda a região. (Tabela 7 )

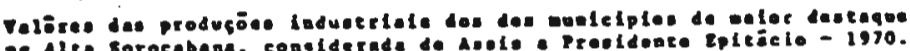
ivelores den prulugöen es all ervizetrosi)

\begin{tabular}{|c|c|c|c|c|c|c|c|c|c|c|}
\hline \multirow{3}{*}{ 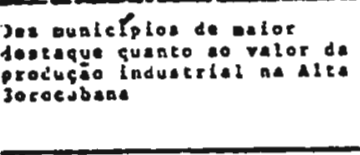 } & \multirow{2}{*}{\multicolumn{2}{|c|}{$\begin{array}{l}\text { Valor cocel de - } \\
\text { produrio induler. }\end{array}$}} & \multirow{2}{*}{\multicolumn{2}{|c|}{ Alimenesr }} & \multirow{2}{*}{\multicolumn{4}{|c|}{ 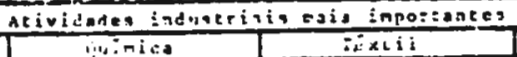 }} & \multirow{2}{*}{\multicolumn{2}{|c|}{ S14ueined }} \\
\hline & & & & & inim & & $\pi=\times L$ & & & \\
\hline & Abeólute & 2 & $\begin{array}{l}\text { Yelor de } \\
\text { Produgio }\end{array}$ & 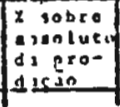 & $\begin{array}{l}\text { valor da } \\
\text { produgao }\end{array}$ & $\begin{array}{l}\text { sobre } \\
\text { absoluco } \\
\text { sopose } \\
0\end{array}$ & $\begin{array}{l}\text { Valor din } \\
\text { produgion }\end{array}$ & 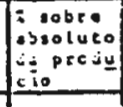 & $\mid \begin{array}{l}\text { visor de } \\
\text { producajo }\end{array}$ & 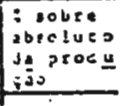 \\
\hline 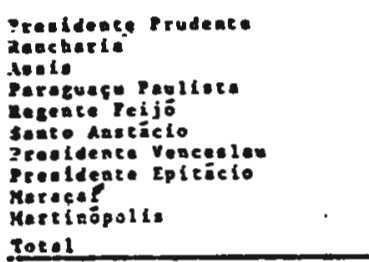 & $\begin{array}{r}83.219 \\
27.693 \\
18.621 \\
12.021 \\
10.127 \\
8.880 \\
6.300 \\
6.030 \\
3.428 \\
4.840 \\
167.139 \\
\end{array}$ & $\begin{array}{r}39.0 \\
16.6 \\
11.1 \\
3.2 \\
6.1 \\
3.3 \\
3.0 \\
3.6 \\
3.2 \\
2.9 \\
100.0 \\
\end{array}$ & $\begin{array}{r}30.220 \\
17.699 \\
7.762 \\
862 \\
1.096 \\
3.118 \\
3.361 \\
1.136 \\
4.678 \\
361 \\
70.219\end{array}$ & $\begin{array}{l}46.3 \\
63.1 \\
41.8 \\
7.0 \\
19,8 \\
35,4 \\
40.5 \\
18.8 \\
36,2 \\
11.6 \\
42.0\end{array}$ & 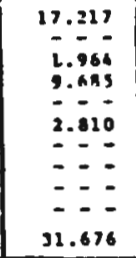 & 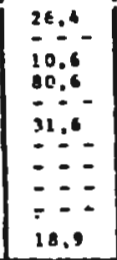 & \begin{tabular}{l}
$4.0<6$ \\
9.253 \\
3.316 \\
\hdashline$-5=$ \\
2.682 \\
2.794 \\
$\square=0$ \\
3.950 \\
26.037
\end{tabular} & 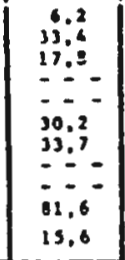 & 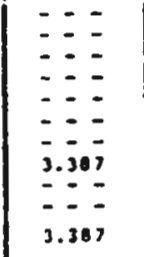 & 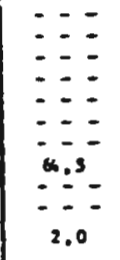 \\
\hline
\end{tabular}

Poutes conso Induetín - sễo Paulo - 1970

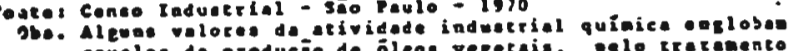

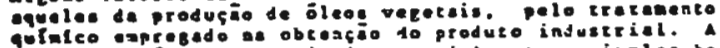

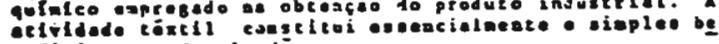
eellelusenco do d lgodio.

o setor industrial paraguaçuense, nascido do mesmo proces so que define as atividades rurais e urbanas na Alta Sorocabana, apresenta as mesmas caracteristicas de desenvolvimento, os quais foram vistos na evolução das funções.

Durante o ano de 1974, o valor total das vendas dos produ tos industrializados paraguaçuenses somou pouco mais de $160 \mathrm{~m}$ Ihōes de cruzeiros, cabendo às ligadas à coleta e beneficiamento de matérias primas destinadas à um mercado consumidor distante a participação de 87,308 ; às Indústrias de mercado local e regionảl 9,748 e àquelas cujo maior mercado é o local, apenas 2,488 (Taje 1 a 8 ) 
Valor das vendas da indústria paraguaçuẹse, por tipo e segundo $>$ mercado consumidor.

Paraguaçu Paulista- $1974 \quad$ Tabela 8

\begin{tabular}{|c|c|c|}
\hline $\begin{array}{l}\text { Indústrias segundo o tipo } \\
\text { e mercado consumidor }\end{array}$ & $\begin{array}{c}\text { Valor das } \\
\text { vendas }\end{array}$ & $\begin{array}{l}z \text { sôbre o va } \\
\text { lor total dass } \\
\text { vendas }\end{array}$ \\
\hline $\begin{array}{l}\text { I- Indústrias de mercado distante } \\
\text { coleta e beneficiamento de pro } \\
\text { dutos rurais (fäbica de oleos } \\
\text { vegetais, bencficiamentos de } \\
\text { algodao, arroz, cafe.......... }\end{array}$ & $\cdot$ & 87,30 \\
\hline 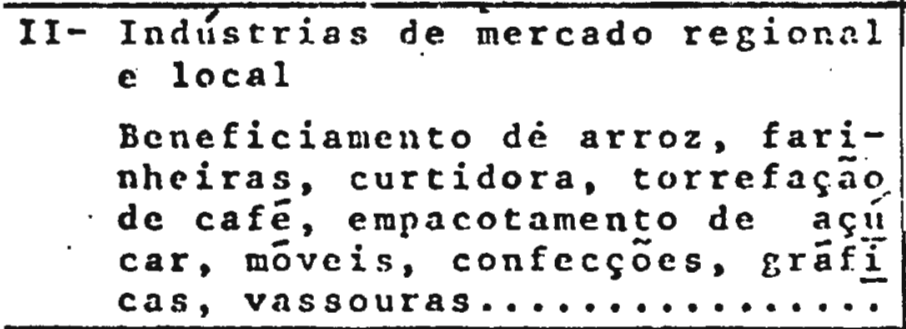 & $15.585 .264,00$ & 9,74 \\
\hline 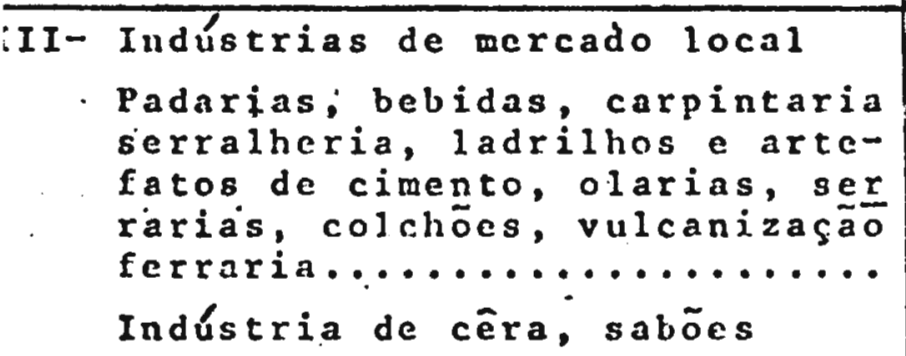 & $\begin{array}{r}3.974 .358,00 \\
773.748,00\end{array}$ & $\begin{array}{l}2,48 \\
0,48\end{array}$ \\
\hline$\therefore 2=2 \dot{\alpha}=$ & iúv. iqū. $\dot{4} \dot{4} \bar{t}, \bar{u}$ & iùu,u \\
\hline
\end{tabular}

Fonte: Declaraço de dados informativos necessïrios à apurasão do- índices de participação do ICM, moḍ́ 10 "B". - 1374

Portanto, o fundamental da Indústria paraguaçuense são as ativida des tradicionais, cujas origens datam do período que vai dos prí mórdios da cidade à década de 1940-

\subsubsection{Origem dos Capitals}

Da anālise de 18 entrevistas.realizadas em diferentes in dústrịas paraguaçuenses; verificou-se que, exceto a Anderson Clay̆ ton e SAAD, que se constituem nas maiores, todas as demais têm origem e capitais locais.

Ao considerarmos a origem deste pessoal, segundo a natura lidade e atividades anteriores, temos o seguinte: . constitui menor parcela (25\%) a infciativa de paulistas, enquanto que a maior parte (75\%) é proveniente.de imigrantés ou descendentes destes - Japonéses (258), italianos, $(18,7 \%)$, alemães $(18,78)$ e portugue ses $(12,5 q)$, cujas atividades anterioras foram as de proprietárí os ou arrendatários rurais, comerciantes e operários; èstes ülti mos evolulram para industriais de estabelecimentos .. semelhantes 
àqueles onde eram operārios. (Tabela 9)

Orlgem do capital das atividades induseriais paraguaçuenses, segundo a naciona 1idade ou descendencia e as atividades anteriores exercidas por seus proprieta rloa.- Paraguaçu Paulista - amostragem $1973 / 74$.-

Tabela 9

\begin{tabular}{|c|c|c|c|c|c|c|c|c|c|c|c|c|}
\hline \multirow{3}{*}{$\begin{array}{l}\text { Maclonalidade } \\
\text { ou descendén } \\
\text { cla }\end{array}$} & \multirow{2}{*}{\multicolumn{2}{|c|}{ total }} & \multirow{2}{*}{\multicolumn{2}{|c|}{$\begin{array}{l}\text { Terciário } \\
\text { de } \\
\text { comércio }\end{array}$}} & \multirow{2}{*}{\multicolumn{2}{|c|}{ Secundērio }} & \multirow{2}{*}{\multicolumn{4}{|c|}{$\frac{p r i m a j r}{\text { edad grande prof }}$}} & \multirow{2}{*}{\multicolumn{2}{|c|}{0}} \\
\hline & & & & & & & & & & & & \\
\hline & abs & $\%$ & abs & 3 & abs & 7. & abs & $\%$ & abs & 7 & abs & 7 \\
\hline $\begin{array}{l}\text { Jeponesa } \\
\text { Italiana } \\
\text { Ilema } \\
\text { Portuguesa }\end{array}$ & $\begin{array}{l}4 \\
3 \\
3 \\
2\end{array}$ & $\begin{array}{l}25,0 \\
18,7 \\
18,7 \\
12,5\end{array}$ & $\begin{array}{l}1 \\
2 \\
2 \\
-\end{array}$ & $\begin{array}{l}25,0 \\
66,7 \\
66,7 \\
-\end{array}$ & $\begin{array}{l}- \\
1 \\
1\end{array}$ & $\begin{array}{l}\overline{33}, 3 \\
5 \overline{0}, 0\end{array}$ & $\frac{1}{1}$ & $\begin{array}{l}25,0 \\
- \\
33,3 \\
50,0\end{array}$ & $\begin{array}{l}1 \\
- \\
-\end{array}$ & $\begin{array}{l}25,0 \\
= \\
=\end{array}$ & $\begin{array}{l}\vdots \\
\vdots \\
-\end{array}$ & $\begin{array}{c}25.0 \\
= \\
=\end{array}$ \\
\hline Paulsta & 4 & 25,0 & - & - & 3 & 75,0 & - & - & - & - & 1 & 25,0 \\
\hline Totais & 16 & 100,0 & 5 & 31,2 & 5 & 31,2 & 3 & 18,7 & 1 & 6,3 & 2. & 12,5 \\
\hline
\end{tabular}

Portanto, capitais e indústrias locais são oriundos tanto de iniclátivas urbanas quanto rurais. Entretanto, segundo a or gem do capital (urbano ou rural), nacionalidade ou descendência e a atividade inaustrial ora definida (Quadro 1 ), tem-se outra ' distribuição.

Origem do capital - urbano ou rural - e atividade industrial ora definida, segundo a nacionalidade ou descendencia de seus proprietários.

Paraguaçu Paulista - amostragea $1973 / 73$

Quadro 1

\begin{tabular}{|c|c|c|c|c|c|}
\hline \multirow{2}{*}{$\begin{array}{l}\text { origem do capital e } \\
\text { atividade industrial } \\
\text { ora definida }\end{array}$} & \multicolumn{2}{|c|}{ Nacionalidade } & \multicolumn{2}{|c|}{ ou descendência. } & \multirow[b]{2}{*}{ Paulista } \\
\hline & Japonesa & Italiana & Alcmä & Portiguesa & \\
\hline \multicolumn{6}{|l|}{ I- De origem urbana } \\
\hline $\begin{array}{l}\text { 1. Móveis } \\
\text { 2. Eeneficiarento de arroz, }\end{array}$ & 1 & 1 & - & 1 & - \\
\hline $\begin{array}{l}\text { café, milho } \\
\text { 3orzefaçao de café, tritu } \\
\text { raf,áo e empacotamento de }\end{array}$ & - & 1 & 1 & - & - \\
\hline $\begin{array}{l}\text { açucar } \\
\text { 4. Ceras, sabões e velas }\end{array}$ & $\overline{-}$ & $\overline{1}$ & 1 & $\overline{-}$ & 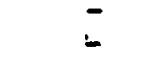 \\
\hline $\begin{array}{l}\text { 5. Tipografia } \\
\text { 6. Ladrilhos e artefatos dd }\end{array}$ & - & - & - & - & 1 \\
\hline $\begin{array}{l}\text { Cimento } \\
\text { 7. Colchoaria }\end{array}$ & $\overline{-}$ & - & $\overline{-}$ & $\overline{-}$ & $\begin{array}{l}1 \\
1\end{array}$ \\
\hline 8. Serralheria & - & - & - & - & 1 \\
\hline \multicolumn{6}{|l|}{ II-De origem rural } \\
\hline $\begin{array}{l}\text { 1. Bebidas } \\
\text { 2. Curtidora }\end{array}$ & 1 & - & $\overline{1}$ & $\overline{-}$ & $\overline{-}$ \\
\hline $\begin{array}{l}\text { 3. Eeneficiamento de arroz } \\
\text { 4. Gráfica } \\
\text { 5. Vassouras }\end{array}$ & $\frac{1}{1}$ & $\ddot{-}$ & $=$ & $\overline{1}$ & $\overline{-}$ \\
\hline$T \cap I A L$ & 4 & 3 & 3 & 2 & 4 \\
\hline
\end{tabular}

Fonte: levantamento por amostragem realizado em $1973 / 74 .-$ 
As atividades industriais nascidas de capitais urbanos ten duas origens, segundo a atividade exercida anteriormente pe los seus proprietários: do terciário (comércio) ou do secundário.

No primeiro caso as indústrias surgem da transferência de capitais do comércio, financiamentos bancários e da experiência obtida pelo proprietário no ramo comercial: móveis, beneficiamen to de arroz, de café, farinheira (milho), torrefação de café e trituração e empacotamento do açúcar cristal. Neste grupo, ape nas a indústria de ceras, sabōes e velas têm o capital originado da acumulação feita pelo seu proprietário como viajante (Cia. Urano de Capitalização).

Quanto ao setor secundário como criador de novas indústrí as, notamos o seguinte: há indústrias cujos capitais são resul tantes das experi ências obtidas pelos seus proprietários como operários do mesmo ramo industrial, que conjungam às suas eco nomias os empréstimos e financiamentos. Nesta situação estão as duas indústrias de móveis de menor porte, a tipografia, fābrica de ladrilhos e artefatos de cimento, fábrica de colchões e a ser ralheria. Esta última tem o capital inicial originado principalmente de firanciámentos dos fornecedores de maṭéria prima:

As Indústrias de capital nriundn dn moin rural; proviâm te pequenos proprietārios agricultores, grande proprietário pecua rista e agricultor e de arrendatários.

Do primeiro caso verifica-se a presença de duas indústrias onde uma delas (bebidas) tem o capital inicial proveniente da ven da de pequena propriedade cafeicultora e a outra (curtidora), o capital originou-se de atividade agropecuária e curtume exercidas em pequena propriedade rural paterna.

A grande propriedade rural proporcionou o capital para a aquisição de grãfica, que jã existia na cidade

Os arrendatārios, em número de dois, transferiram-se para - centro urbano empregando suas economias rurais em beneficiamen to de arroz e em fábrica de vassouras. Este último não se caracte riza essencialmente como arrendatário, uma vez que ao lado desta atividade exerceu, na mesma propriedade rural, a função de admi nistrador.

Observa-se ainda que; embora desenvolvendo a atividade no secundário, alguns destes industriais exercem atividades parale las comerciais, rurais e mesmo administrativas.

Nesta sistuação acumulativa de atividades, verifica-se um industrial de móveis com comércio de móveis não só da sua indūs tria, e eletrodomésticos; ao lado da gráfica, seus proprietārios 
permanecem com a grande propriedade rural e com função adminis trativa pública; un industrial de café e açúcar é concessionārio de veículos, participa como sóclo de papelaria, farmácia, sendo, também, grande proprietário rural voltado principalmente para a pecuária; um beneficiador de café e arroz possui grandes proprie dades com pecuária criatóría e agricultura, comércio de cereais' no atacado em média escala, transportadora, posto de gasolina; um fabricante de artefatos de cimento mantém, também, pequena proprie dade rural, o mesmo acontecendo comum industrial de bebidas que possui propriedades rurais voltadas principalmente para a pecuäria.

\subsubsection{Controle e Gestão}

o controle e gestão das Indústrias paraguaçuenses, consi derando-se os valores das vendas das mesmas para 1974, são de duas ordens: externo $(83,648)$ e local $(16,368)$.

o controle externo caracteriza-se pela existēncia de ati vidades industrlais ligadas à coleta e beneficiamento de produtos rurais que Interessam um mercado distante, internacional e nacio nal. As suas presenças resultam, inicialmente de instalação de usí nas de beneficiamento de algodão da Anderson \& Clayton e da Cia. SAAD do Brasil e de outras que desapareceram (SANBRA, Mac Fadden) e, posteriormente, da fábrica de óleos vegetais pertencente à pri meira, fatos já referidos anteriormente.

Igualmente, o contröle local na sua maior parte é feito por empresas voltadas à coleta e beneficlamento ou pequenas transfor maçōes de produtos agropecuários. Dos 16,378, estas controlam _ 11,268 , das quals apenas uma volta-se ao mercado distante - bene ficiamento de arroz e cafē $(3,668)$-. As demais são de mercado regional e local ou apenas local.

Portanto, embora haja predominância numérica da iniciati va local, apenas a presença de duas organizações externas (Ander son \& Clayton e SAAD), expressam a dependência e o peso da indús tria em Paraguaçu Paulista, tendo a primeira delas valor destaca do: o valor de suas vendas para o ano de 1974 representou 76,088 dos valores totais das vendas industriais de Paraguaçu Paulista.

Estes grandes estabelecimentos industriais constituem, no núcleo urbano paraguaçuense, unidades da ampla rede coletora de pro dutos ruraís que as grandes empresas possuem, tanto em âmbito esta dual quanto nacional. A expansão ou arrefecimento e mesmo decli nio de suas atividades em Paraguaçu Paulista, são marcadas pela evo lução que os diferentes produtos (algodão, amendoim, mamóna, so ja) apresentam desde os anos 40, cujas presenças na Alta Sorocabana, norte e noroeste do Paraná e sul de Mato Grosso, sempre foram dita 
das em função dos apelos e interesses dos mercados distantes. No início a expansão do algodão define o estabelecimento de usinas de beneficiamento do produto. Este fato somado à localização de Paraguaçu Paulista dentro de um sistema viário que facilitava o fluxo de matéria-prima das áreas de produção e o escoamento do produto semi-elaborado aos centros de tratamento, consumo e expor tação, constituem fatores importantes para a localização da fá brica de óleos vegetais da Anderson \& Clayton em Paraguaçu Paulis ta, sendo válidos alnda hoje quando a empresa dentro de suas dí retrizes projeta a ampliação da mesma.

No momento de sua instalação (1946) a fábrica de ōleos ve getals trabalhou apenas o caroço de algodão. A partir de 1960 pas sà a moer, tambēm, o amendoim face à importância que este produto assume, em termos de produção, na Alta Sorocabana. Ainda em melo a esta década inicia a moagem da mamona. Em 1974 deixa es tes produtos e passa a moer apenas a soja.

Os três primeiros produtos movimentavam a indústria suce dendo-se de acordo com os períodos de safra dos mesmos: Iníciodo ano moagem do amendoin, o caroço de algodão ocupava os meados do ano, e por fim a mamona fechava o ciclo anual.

A decadêncla da produção algodoeịra na Alta Sorocabana , o desinteresse que surge em relação ao amendoim tanto por partc do produtor quanto dos consumidores de seus produtos industriali zados, a queda de procura e valor da mamona no mercado externo , ao lado do interesse e valor que a soja desperta nos últimos anos, levam a indústria a abandonar aqueles e voltar-se a esta, moti vando inclusive o projeto de ampliação da unidade industrial de 300 toneladas/dia para 600 toneladas /dia. Este projeto surge em função do aumento da produção de soja na Média e Alta Sorocabana, sul de Mato Grosso e principalmente no norte e noroeste do Para ná, ao lado dos objetivos da empresa em concentrar suas atividades neste setor industrial em poucas e grandes unidades.

Entretanto, a expressão da unidade paraguaçuense não está. apenas vinculada aos fatos vistos acima, mas por constituir-se. tambēm, no centro de "manutenção, prođução e instalação de equipa mentos às demais fãbricas da organização, não só no Brasil, como no exterior. (16)

(16) - A partir desta unidade industriál foran produzidos e instala dos equipamentos e fornecida mão-de-obra para a montagem da fábrica de Cruz Alta (RGS, 1959), para a ampliação das fáa bricas de Londrina ( $P R, 1974$ ) e Cruz Alta (1974). Atualmeñ te csta produzindo parte do equipawento para a grande uni dade industrial da A. Clayton, em montagem, em Ponta Grossa= (PR). Em 1967 a organização desloca o pessoal da "oficina" da fabrica de Paraguaçu Paulista paramontagem de unidade industrial em lima (Peru). Cabe ressaltar que $q$ pessoal 1 i gado a esta atividade e, na sua maioria, da propria cidade e treinado e preparado na unidade indsutrial paraguaçuense. 
o beneficiamento de algodão destinado à produção de pluma e caroço, realizado pela ünica usina remanescente da atividade in dustrial em Paraguaçu Paulista, uma das unidades do grupo SAAD (Instalada em 1945) completa o quadro de contröle externo $(7,56 \%)$.

Entretanto, cabe ressalvar que, face à inexistência de ma téria-prima suficiente para o seu funcionamento em 1975, esta não movimentou seus descaroçadores. A partir da safra de 1974, passa a atuar como entreposto de compra de algodão, soja (120.000 sacas em 1974), milho (4.000 sacas no mesmo ano), amendoin, que transfere para a fábrica de óleos de Birigui (BIOL-fábrica de óleos, re finaria, enlatamento), única do grupo SAAD no interior paulista.

\subsubsection{Matéria-Prima}

A matēria-prima para as indústrias localizadas em Paragua çu Paulista apresenta um quadro espacial de proveniência bastan te diversificado, mas com forte presença do norte e noroeste do Páraná, sul de Mato Grosso e Alta Sorocabana face ao desenvolvimen to dos produtos rurais nestas áreas e que se constituem fundamen tais para as atividades industrials de maior expressão na cidade.

Durante $O$ ano de 1974, a făbrica de óleos.vegetais traba lhou 53.700 toneladas de soja, o que constituiu aproximadamente' 148 da moagem total do produto pela empresa no Brasil. Deste to tal de matērla-prima trabalhada pela unidade paraguaçuense, 66,67\% procederam do morte e noroeste do Paranā, 20,488 da Média e Alta So rocabana (espaço compreendido entre Ourinhos e Presidente Epitä cio) e 12,488 do sul de Mato Grosso (região de Dourados, Ponta Porã e Maracaju).

O beneficiamento de algodão (SAAD) na safra de 1974 rece beu e trabalhou 3.616 toneladas do produto em rama, das quais 73,348 procederam da Alta Sorocabana e 26,66\% do norte do Para nā, principalmente das āreas de Bandeirantes e Itambaracá.

o beneficiamento de arroz apresenta duas orientações no abastecimento, segundo o porte das indūstrias: o pequeno estabele cimento adquire a matēria prima (aproximadamente 150 toneladas' em 1974) na área rural próxima (308) oU de cerealistas e maquints tas do Estado de Mato Grosso (70z-Coxim, Rondonópolis, Jaciara); - médio estabelecimento a adquire (aproximadamente 500 toneladas em 1974 ) junto aos produtores locais (58), na Alta Sorocabana (6 a 78), Estado de Mato Grosso (26z-sidrolândia, Cáceres, Rondonō polis, Campo Grande) e no Estado do Paranā (628 - quase que es sencialmente na ārea de Guarapuava).

o beneficlo de café, realizado por uma única empresa (que 
constituiaquela de médio porte no beneficio do arroz), abastece-se na sua quase totalidade no município (80\%) e áreas próximas: Lutēcia (108), Borā (5\%) e Quatā (5\%). Em 1972 o estabelecimento adquiriu e trabalhou aproximadamente 500 toneladas de café em có $\mathrm{CO}$;

Neste setor de coleta e beneficiamento de produtos rurais de mercado distante, a comercialização da matēria-prima proceden te do município e de áreas próximas faz-se diretamente com a pre sença do produtor no estabelecimento industrial. Das āreas dis tantes a aquisição é feita com a presença do Industrial ou seus representantes (entrepostos de compra, compradores, etcss) que efetuam as transações comerciais diretamente com o produtor, coo perativas e maquinistas.

- primeiro caso é mais comum para o algodão e café e o segundo ( de áreas mals distantes) para a soja e arroz،

No caso particular da Anderson \& Clayton, dentro de uma autonomia que cada unidade industrial possui dentro da organiza ção, a fábrica de Paraguaçu Paulista adquire a matéria-prima nos diferentes e mais distantes locais, levando em conta que hă cer to equilíbrio no custo do produto adquirido acrescido do frete en tre áreas mais pröximas e mais distantes, isto é, se a soja a ser adquirida encontra-se mais distante, o seu preço é menor e o fre te maior, ocorrendo o inverso para as āreas mais próximas. Emtre tanto, os "carreteiros" influem, embora parcialmente, neste custo, isto porque preferem distâncias maiores, cobrando pouco me nos, sendo compensados pela eliminação do tempo perdido em car gas e descargas, geralmente demoradas.

A torrefação de café, que em 1972 trabalhou 720 toneladas de café verde, adquire-o nas mesmas āreas em que o beneficiamento de café o faz: 60 a 708 no município e 30 a 408 nos municípios v1 zinhos: Lutécia, Quatá e Borá, sendo que as participações destes oscilam para mals ou menos em função do tipo e preços do produto. Pertencente à mesma empresa, a trituração e empacotamento do açúcar cristal, adquiriru no mesmo ano 3.600 toneladas do pro duto. Estas procederam das usinas localizadas nos municípios de Quatā' (60\%), Araraquara (20\%), Nova Europa (18\%) e Maracaí (28).

o setor de mózeis diversifica-se bastante quanto às áreas de abastecimento. A madeira bruta serrada para estas indústrias ' procede do Estado do Paraná (80\%) - regiões de Guarapuava, Campo Mourão, Arapongas, Terra Rica -, do Estado do Mato Grosso (10 a 158) ou das serrarias de Presidente Epitācio, na Alta Sorocabana ( 5 a 10\%), constituindo neste último caso, madeira procedente de 
Mato Grosso.

A madeira proveniente do Estado do Paraná, principalmente pinho e imbuia, é, na sua maior parte, comercializada através da firma Madeireira Nacional, sediada na capital paulista, embora a remessa da mátēria-prima seja feita diretamente das áreas de pro dução para as indústrias paraguaçuenses. A peroba, o amendoim outras mais duras provêm principalmente do Estado de Mato Grosso e, em parté, via Presidente Epitácio.

Os laminados procedem em 958 de Curitiba (PR) e apenas 58 de Patos de Minas (MG), enquanto que os aglomerados, fórmica, são fornecidos pela capital paulista na sua totalidade (Duratex, AI plan, Formiplac). Os demais produtos: verniz, cera, metais, fer ros, espelhos e outros, procedem na sua totalidade de indústrias paulistanas.

o abastecimento das indūstrias de móveis faz-se principal mente pela atuação direta dos proprietários destas (708) nas ma deireiras, serrarias e industrias paulistanas e através da preæn ça de viajantes junto àquelas (30\%).

As demais indústrias deste grupo de mercado regional e lo cal, abastecem-se principalmente na Alta Sorocabana e na capital paulista: gräficas têm 100\% da matēria-prima utilizada proceden te de São Paulo; a indústria de confecções adquire-a na capital paulisța e em Americana (SP); a curtidoŕa compra o couro cru na Alta Sorocabana, no espaço compreendido entre Palmital e Martinō polis, e o tanino (Acácia Negra) no Rio Grande do Sul; a fābrica de vassouras recebe o sorgo do Rio Grande do sul e os demais pro dutos necessários (cabos, arames) de Presidente Prudente, Tupã, ourinhos. As fäbricas de farinhas (milho e mandioca) têm abaste cimento garantido pelas produções do município.

De maneira geral as compras são feitas atravēs da presença de viajantes, havendo, evidentemente, variações em que o pro prietário adquire a matēria-prima diretamente do produtor, seja'. procurando-o na sua propriedade rural ou efetuando a transação no pröprio estabelecimento industrial. Estes fatos ocorrem princ1palmente com as farinheiras e a curtidora.

As indústrias de mercado local, que no conjunto constituem pequenos estabelecimentos, têm o grosso da matéria-prima proce dente diretamente da região paulistanaou redistribuída pelos ata cadistas, ou representantes das mesmas, estabelecidos nas cidades' maiores do interior do Estado de são Paulo, havendo alguns destes produtos cuja redistribuição è- feita pelo comércio local.

A farinha e demais produtos utilizados pelas panificadoras 
procedem diretamente dos moinhos e indústrias paulistanas, exce to o açúcar que è adquirido localmente. O ferro utilizado pela serralheria e fäbrica de ladrilhos e artefatos de cimento è re distribuido por firmas estabelecidas em Presidente prudente (Ma cife - 558), Assis (Atlas - 30\%), Bauru (Bauru Aço - 10\%) e dire tamente de são Paulo - 58. o cimento, granito e areia lavada, utilizados principalmente pela fábrica de ladrilhos, tem a seguin te procedência: o primeiro é redistribuído pelas firmas comerciais paraguaçuenses ( 808 ) ou por aquelas de Ourinhos e Assis (20\%); - segundo procede totalmente de Bauru, enquanto que a terceira é obtida dos portos de extração de areia do rio Paranapanema nos municípios de Cândido Mota e Florínea. As făbricas de bebidas adquirem o açúcar das usinas localizadas nos municípios de Mara cal e Quatā, ou de atacadistas (Gentil Moreira S/A), e os demais produtos, tais como essências, aromas, rolhas metálicas, de fir mas paulistanas e campineira. As carpintarias obtêm a madeira da serraria local que tem, por sua vez, as toras lavradas proceden tes de Presidente Epitācio.

\subsubsection{Produção e Mercado Consumidor}

A produção interessando mercado extra-regional distante, configurada no beneficiamento de produtos rurais e que constitui no mais importante do setor industrial paraguaçuense, restringe -se atualmente à extração de óleos vegetais e subprodutos des ta ou no simples beneficiamento de algodão, café e arroz, mas cujos valores das vendas têm forte peso nos valores das vendas totais da indústría paraguaçuense, como jā se viu.

Em 1974 os 76,088 de participação da Anderson \& Claytonde Paraguaçu Paulista no valor total das vendas industriais, resul taram da moagem de 53.700 toneladas de soja, obtendo uma produ ção aproximada de 198 de óleo bruto, 778 de farelo e uma perda de apenas 48. Desta produção, parte destinou-se ao mercado in terno e outra à exportação.

o óleo produzido em Paraguaçu Paulista fol transferido pa ra a refinaria da empresa localizada em são Paulo (Bairro da La pa), de onde pode seguir dois caminhos: sofre a refinação, enla tamento e comercialização, ou é exportado no seu estado bruto.

Do total de óleo bruto exportado pela empresa, aproximada mente 15 a 208 da sua produção total, coube à fābrica de Para guaçu Paulista, em 1974, uma pảrticipação aproximada de 108 nes 
ta exportação.

- farelo destina-se ao consumidor direto, aos fabricantes de rações ou à exportação. Do farelo produzido em 1974, a Ander son \& Clayton do Brasil exportou 808 e destes, 158 saíram da fá brica Paraguaçuense, significando 748 da produção deste sub produto nesta unidade industrial. Os restantes 258 destinaram-se ao mercado paulista (faabricas de rações) e mineiro (consumidor direto) em proporções equivalentes, ficando o mercado local com mais ou menos 28 .

Quando se trata de mercado interno as transações (remessa de matéria-prima -óleo bruto-, ao setor industrial de são Paulo, comercializações) são feltas a partir das orlentações e diretri zes da matriz de são Paulo, sendo, entretanto, cada unidade autô noma para realização das vendas, o que ocorre também para.as com pras. Quanto ao comérclo externo, os negóclos podem ser feltos por intermédio da matriz estadunidense (Houston) ou diretamente por São Paulo. Entretanto, o faturamento 'é feito pela fábrica que produziu, podendo ser refaturado ou nos Estados Unidos ou na Europa (Lausane- Suíça) e seguir outro destino.

o beneficiamento de algodão, representado apenas, pela us 1 na de beneficlamento da Cia. SAAU do Brasil (7,568 do valor das vendas industriais de Paraguaçu Paulista em 1974) apresentou, em 1974, uma produção Industrial de 1.250 tóneladas de pluma e 2.150 toneladas de caroço de algodão. A pluma teve como destino a Cia. Independente de Armazéns Gerais - são Paulo, capital - depositada em nome da Cia. SAAD do Brasil, que posteriormente realizou a sua comercialização. Quanto ao caroço, 1900 toneladas foram ven didas diretamente a partir de Paraguaçu Paulista para as fābricas de óleos vegetals da Cia. Matarazzo, localizada em Rancharia (900 toneladas), e às unidades industriais da SANBRA, localizadas em Ourinhos e Bauru. Além, produziu 250 toneladas de caróço ob tidas do algodão de Campos de Cooperação da Secretaria da Agricultura do Estado de São Paulo, consideradas como sememtes, que foram remetidas e depositadas no Posto de Sementes de Paraguaçu Paulista.

o beneficiamento de arroz e café, das mais antigas atividades Industriais de Paraguaçu Paulista, considerando-se o merca do consumidor distante, é constituído por uma única empresa (3,36 por cento de participação no valor total das vendas industrials), cujas produções destinam-se fortemente àquele mercado. . 0 arroz tem suas grandes vendas realizadas para a área de campinas (80\%) 
enquanto que as parcelas menores destinam-se às āreas de Bauru (58), Marfilia (128) e local (38). A comercialização é realizada diretamente pelo industrial, cujos clientes são . essencialmente atacadistas, exceção feita ao consumo local, representado pelas pequenas firmas.

- café, uma vez beneficiado e classificado, a empresa reme te-o para Santos onde o comercializa com firmas exportadoras: An derson \& Clayton, Yoshioca e Cia., Queiroz Ferreira - Comissāria Exportadora S/A, Terácio Exportadora S/A.

Para entregas do arroz e remessa do café, utilizam o-cami nhão, tendo-se em conta que a firma industrial é detentora de em presa de transporte.

As atividades de mercado regional e local alcançam, além da Alta Sorocabana e Alta Paulista, parte do Norte e Noroeste do Paranā e Sul de Mato Grosso, tendo sua maior expressão no setor alimentar: beneficiamento de arroz, torrefação de café, trituração e empacotamento do açúcar cristal. Estas atividades participaram em 1974 com 6,058 do valor total das vendas industriais pa raguaçuenses, cabendo à primeira apenas 0,868 ès duas outras 5,198. Nestas a participação aparece englobada por pertencerem a uma ünica unidade industrial.

Realizado por quatro firmas de pequeno porte, das quais a de maior destaque possui o empacotamento do produto, o beneficia mento de arroz tem mercado consumidor restrito às áreas próximas (Quatá, Lutécia, Oscar Bressane, Borā) na ordem de $60 z$ e local mente sạo absorvidos os restantes $40 \%$. O consumidor principal constitui o pequeno e médio comerciante varejista e a população que adquire o arroz diretamente das "máquinas".

o café e açúcar apresentam mercado consumidor semelhante, sendo mals amplo para o segundo, como demonstra o quadro abaixo:

Mercado consumidor do café e açúcar cristal

\section{Paraguaçu Paulista - 1972}

Mercado consumidor

Paraguaçu Paulista

Alta Sorocabana (exceto P. Paulista) 558

Alta Paulista

Sul de Mato Grosso

Norte e Noroeste do Paraná
Quadro 2

Açúcar

108

358

308

108

158

Fonte: Entrevista realizada direta mente na firma - 1972.- 
Neste mercado consum1dor nota-se que o maior peso é repre sentado pelo comerciante varejista, incluíndo-se os supermercados que por sinal se destacam.

Secundariamente hã as indústrias de móveis e esquadrias de madeira, cuja participação no mesmo ano (1974) no valor total das vendas da indústria paraguaçuense, somou 1,648; as gráficas com 0,868 e finalmente as farinheiras (mandioca e milho), a cur tidora, făbrica de vassouras e a indústria de confecçōes, que englobadas participaram com 1,438.

o setor de móveis e esquadrias è representado por três in dústrias, das quais uma se destaca, apresentando 77,88 de partí cipação no valor total deste ramo de atividade industrial.

Neste setor o grosso da produção é composto pelos móveis, tanto da linha de produção em série, quanto encomendas e peças em separado, aparecendo em segundo plano as esquadrias de madeira. Encontra-se tal. disposição, pelo fato de que a principal indús tria do setor volta-se em 1008 para a produção de móveis.

o mercado consumidor, constituído por varejistas, emprei teiras de obras-que en alguns casos constituia própria indústria(esquadrias principalmente), encomendas ou consumidor direto, tem a seguinte distribuição:

Mercado consumidor da Indústrias de Móveis e Esquadrias Paraguaçu Paulista - 1973.

Quadro 3

Mercado Consumidor

Paraguaçu Paulista

São Paulo e Santos Móveis . esquadrias

Alta Sorocabana (exceto Parag. Paulista)

Alta Paulista

Norte eNororeste do Paraná

Sul de Mato Grosso

$\begin{array}{cc}158 & 658 \\ 208 & 358 \\ 288 & - \\ 198 & - \\ 178 & - \\ 18 & -\end{array}$

Fonte: Entrevistas realizadas dire tamente nas indústrias, 1973

A atividade gráfica, constituída por duas empresas, das quais a mais representativa responde por 80,68 do valor das veñ das da atividade, tem uma produção fortemente orientada para os impressos em geral (90z) e como produto minoritário os cadernos (108), sendo éste fabricado apenas pela firma de maior porte.

o mercado consumidor é constituído pela Alta e Média Soro cabana - 338 (de Bernardino de Campos a Presidente Epitáclo), Nor te e Nororeste do Paráná - 248, Sul de Mato Grosso - 248 (áreas de Dourados, Ponta Porā, Maracaju), Paraguaçu Paulista - 118, e Alta Paulista - 88 . 
As demais indústrias desta faixa de mercado regional e lo cal têm pouca expressão no secundário paraguaçuense.

As farinheiras, em número de três - duas para a mandioca: e uma paraúmilho - apresentam uma participação no valor total das vendas industriais (1974) de apenas 0,62\%. O mercado consumidor, definido por atacadistas e varejistas, é a Alta Sorocabana (100\%) destacando-se Presidente Prudente (35\%) e Paraguaçu Paulista e áreas prōximas (25\%).

A curtidora com 0,498 de participação naquele total de ven das de 1974, transforma o couro cru em solas que são consumidas pelas casas de couro, sapatarias, selarias de Maringá (PR): 30 , Presidente Prudente: 208, Presidente Venceslau: 208, Tupã: 108.Localmente e nas áreas vizinhas a pequena indústria vende 208 .

A pequena fãbrica de confecções (essencialmente masculi nas) e a fạbrica de vassouras participaram no ano já referido com apenas $0,32 \%$ no valor das vendas industriais. o mercado consumi dor da primeira restringe-se à Alta Sorocabana, enquanto que a segunda distribul os seus produtos na Araraquarense, Alta Paulis ta e Alta Sorocabana.

Este último grupo de indústrias - farinheiras, curtidora, confecções e vassouras - dada à sua pequenez, possuem sistema' mals ou menos comum de comercialização de seus produtos: os in dustriais são ao mesmo tempo o proprietário, viajante, entregador e cobrador.

As indústrias de mercado local são de pequeno porte, cons tituindo-se naquelas que no conjunto apresentaram o menor valor de participação no valor total das vendas industriais, conforme está definido no quadro 4 .

o malor valor das vendas deste grupo é apresentado pela panificação, face ao número de establecimentos que este setor possui. As quatro panfficadoras existentes na cidade participa ram, em 1974 com 0,818 do valor das vendas industriais e respon deram por 36,58 do valor das vendas deste setor de indústrias de mercado local.

As demais atividades - serraria, bebidas ( duas fäbricas de refrigerantes), vulcanização, carpintarias (duas - carrocerias, carretas, carroças), serralheria, ferraria, colchōes, ladrilhose artefatos de cimento - completam ëste quadro de pequenas indús trias. Dentre elas a maior participação cabe à primeira com 0,438 no valor total das vendas da indústria paraguaçuense. 
o mercado consumidor destas "é na sua maior parte local e aquelas que saem deste âmbito alcançam apenas os centros urba nos ou a zona rural próxima, em um raio de aproximadamente $50 \mathrm{~km}$ como pode ser. visto pelo quadro abaixo:

\section{Quadro 4}

\begin{tabular}{|c|c|c|c|c|c|c|c|c|c|c|}
\hline$\cdot$ & $\begin{array}{c}\text { Prea. } \\
\text { (urbano) }\end{array}$ & $\begin{array}{l}\text { P.Pta. } \\
\text { (rural) }\end{array}$ & Ranch. & Quetá & Borã & Luté: & Osc.Bres. & Marecaí & Cruzél. & Lepê \\
\hline Panificadorat" & 1007 & - & - & - & - & - & - & - & - & - \\
\hline Serraria & $85 \pi$ & $15 z$ & - & - & - & - & - & - & - & - \\
\hline Bebidas $(r \in f r i g)$ & 607 & - & 208 & 102 & - & 59 & 58 & - & - & - \\
\hline Vulcanisagäo & $85 \pi$ & $5 z$ & - & 38 & 17 & 17 & - & - & - & - \\
\hline Carpiataria & 52 & 258 & - & +72 & - & $\star 48$ & $\$ 48$ & - 388 & เ $17 \pi$ & - \\
\hline Serralherie & $95 \pi$ & - & - & - & - & 57 & - & - & - & - \\
\hline gerreria & 807 & 208 & - & - & - & - & - & - & - & - \\
\hline Colchoerla & $50 z$ & - & - & $10 x$ & - & - & - & $20 \pi$ & - & 202 \\
\hline rab. 1 adrilhos & $60 z$ & - & - & - & 58 & 157 & $10 \pi$ & $10 z$ & - & - \\
\hline & & & & & & $\begin{array}{l}\text { (a)- } \\
\text { P.Pi:a } \\
\text { Rani:h } \\
\text { Lutiic } \\
\text { guc.By } \\
\text { Cru::a }\end{array}$ & $\begin{array}{l}\text { rcado consu } \\
\text { - Paraguaçu } \\
\text { - Rancharí } \\
\text { - Lutäcia } \\
\text { es.- Oscar } \\
\text { - Cruzália }\end{array}$ & $\begin{array}{l}\text { Didor rur } \\
\text { Pauliste } \\
\text { Bressane }\end{array}$ & & \\
\hline
\end{tabular}

Portanto, a função industrial paraguaçuense, cujas origens remontam ao período compreendido entre os anos 20 ao final da dé cadà de 1340, ful e permanece constituída essenclalmente de ati vidades de transformação banal, caracterizadas pelos beneficiamen tos, que em boa parte complementam as fases iniciais da comercia lização de produtos rurais.

o seu desenvolvimento vinculou-se a produção rural, que por ser pouco diversificada local e regionalmente define por con sequência a implantação de um nümero pequeno de tipos de indús trias e de produtos. Em ambos os casos - produção agrícola e atí vidades industriais - Implantam-se, não só em Paraguaçu Paulista como também na Alta Sorocabana de modo geral, atendendo as ten dências da demanda, principalmente de mercado distante.

Assim, face a uma politica de exportação enfatizando a participação de alguns produtos no mercado externo, ao crescimen to do mercado interno - principalmente paulistano - verifica-se a presença do cafē, algodão, mamona, soja, como produtos que defi nem a orientação e o peso das atividades industriais no secundā rio paraguaçuense.

Estas atividades são marcadas, tanto no passado quanto a tualmente, pela predominância das indústrias alimentares de in clativa externa, configuradas na presença da fábrica de óleos ve getais brutos da Anderson \& Clayton $(76,088$ do valor total das / vendas industriais em 1974 ). 
Neste quadro, o café que gerou uma das mais antigas atí vidades industriais na cidade, permite a presença da iniciativa' local. Esta, ingressa no secundário de mercado distante, coletan do, beneficiando, comercializando e, indiretamente, exportando o café. Isto acontece no momento em que a área deixa de ter inte resse para as grandes organizações, hoje localizadas em espaços que justificam as suas presenças.

As demais indústrias, embora numerosas, são de pouca ex pressão no secundārio paraguaçuense, havendo maiores destaques pa ra a torrefação de café e empacotamento do açúcar, móveis e grā fica.

o seu desenvolvimento e expansão, alcançando a Alta Soroca bana, Alta Paulista, Norte e Nororeste do Estado do Paranā e Sul do Estado de Mato Grosso, resultam das iniciativas de seus propri etários que procuram atuar e garantir um mercado com pequeno cres cimento é clientela essencialmente de comerciantes varejistas, e cujos concorrentes são de níveis semelhantes, regionais ou loc ais. São indústrias de transformação banal, funcionando como prolonga mentos da função de distribuição comercial.

AS pequenas indústrias de mercado essencialmente local, ex primem as necessidades imediatas e o nivel de demanda do centro urbano paraguaçuense e da 'ārea próxima sob sua influēncia. 
3.2.2. A Função de Distribuição de Gêneros Industrials e Agrärios

Ä partir do momemto em que se verifica o revigoramento da zoṇa rural com a presença do trigo e soja substituindo, em parte, as tradicionais atividades agropecuärias, ocupando, valorizando as terras e gerando novas rendas neste leste da Alta Sorocabana, há, como consequência,gradativa melhoria ecorômica que repercute nos níveis de consumo, tipos de produtos consumidos e consumido res.

Estes fatos são sentidos em Paraguaçu Paulista, onde se verifica nos ūitimos anos melhoria no comércio distribuidor de gêneros industriais e agrärios.

o dinamismo, embora relativo, face às próprias limitações econômicás e populacionais da cidade e āxea próxima, pode ser ve rificado através da expansão das empresas voltadas ao atendimento do setor primário, da transformação de casa comercial varejista em pequeno atacadista, da instalação de supermercado de médias proporções (filial de uma rede de cinco estabelecimentos), das trürsformações de estabelecimentos de sècos e molhados de peque no e médio portes em mini-supermercados, da instalação de novas lojas de eletrodomésticos (uma de origem local e outra como fill al de rede de 18 estabelecimentos), da ampliação e reformas de lo jas de tecidos, calçados e farmácias, da transformação de casas de secos e molhados em casas de material de construção e mesmo da abertura de novas firmas neste ramo.

Esta expansão liga-se nāo sómente às mudanças econômicas ocorridas no município e áreas prōximas com a introdução do trî go e soja, mas tambēm -a sua posição nos limites extremos das zonas de influência de duas capitais regionais - Presidente Pru dente e Marília -, ao desenvolvimento do sistema rodoviário do tando-o de várias rodovias asfaltadas e à presença recente de Es cola Superior de Agronomia (1974).

As novas culturas trazem un dinamismo à zona rural que se reflete na cidade e nas relações existentes entre esta e o pe queno espaço sob sua influência.

os reflexos no setor comercial se fazem tanto no atendi mento à própria zona rural, procurando servíla na demanda aos produtos que interessam ao crescimento e consumo de sua produção, quanto naqueles das necessidades básicas ou bens de consumo durá vel, primordialmente urbanos. 
No atendimento à zona rural, os ramos distribuidores de máquinas, tratores, implementos, adubos, inseticidas, apresentam razoável expansão face ao maior gräu de mecanizaçã்o e emprégo de insumos que as novas culturas exigem. Por outro lado, a cidade constituindo-se centro de comercialização de parcela razoável das produções rurais - basicamente aquelas citadas anteriormente - , tem outras funções dinamizadas pelo mecanismo de comercialização e equipamento industrial a elas voltados.

No caso do trigo, que pela estrutura da sua comercialização compete ao Banco do Brasil realizá-la, cabe à cidade, atrá vees de sua agêncla local, a absorção da produção municipal e grande parte daquela da ārea sob sua jurisdição. (17)

Quanto à soja, a comercialização 'é realizada diretamen te com a indústria, no caso a Anderson \& clayton, através de sua fábrica de óleos existente na cidade que drena parcela da pro dução municipal e das áreas próximas. Também a Cia SAAD do Brạ sil age adquirindo a soja, remetendo-a para sua fábrica de óleos localizada em Birigui (SP).

Outros produtos: café, arroz, milho, mandioca, tambēm são comercializados em Paraguaçu Paulista que conta com beneficiamen tos e inđústrias a eles ligados, tendo maior expressão o arroz e café, como jã se viu na função industrial.

Estas atividades constituem-se em carreadoras de rendas pa ra o centro urbano o que estimula vários comerciantes que pro curam melhor atender 'ás necessidades básicas da população e o de bens de consumo durável. Isto se verifica através da presença de novos estabelecimentos ou pela preocupação de alguns proprie tários, jā estabelecidos há tempos, 'em melhorar seus estoques, as condições de seus estabelecimentos, havendo casos de mudanças de ramo de atividades para setores em expansão, como 'é o caso de materiais de construção.

(17) Durante a safra 1974/75, a agência do Banco do Brasil em Paraguaçu Paulista, adquiriu 47.270 toneladas de trigo. Deste total, as maiores aquisiçöes provieram de Cruzália (20.174 ton.), Maracaí (12.029 ton.), Florínea (6.118 ton.) Paraguaçu Paulista ( 3.038 ton.), Rancharia (1.401 ton.) e Assis (1.399 ton.).

Entretanto, foram depositadas na CEAGESP de Paraguaçu Pau 1 ista 8.234 ton. (face a sua capacidade) e o restantems silos e armazéng da Cooperativa Agricola de Pedrinhas (mu nicípio de Cruzália) - 21226 ton., e da Cooperativa Agrícola da Colônia Rio-Grandense (Município de Maracaí) - 14.185 ton.. 
A posição de Paraguaçu Paulista nos limites extremos das zonas de influência de duas capitais regionals, permitiu uma in fluência mais acentuada söbre a área que lhe é próxima e que se constitui, tambèm, no espaço onde Presidente Prudente e Marlíia atenuam suas presenças.

Entretanto, esta influência não se justifica apenas pela presença da cidade neste espaço. A existência de um equipamento' de serviços - Posto de Sementes, Banco do Brasil, CEAGESP, Esco la Superior de Agronomia - e Industrial, já referido, de nível se melhante ao das capitais regionais que se encontram a pouco mais de $80 \mathrm{~km}$. , definiram maiores relações comerciais. entre este es paço e Paraguaçu Paulista.

Perceptores destes fatos e daqueles anteriormente citados relacionados às novas culturas, comerciantes paraguaçuenses, prin cipalmente aqueles dotados de maior iniciativa, procuram usufruir dos mesmos, melhorando seus estoques, abrindo novas lojas e não se restringindo ao atendimento interno, mas procurando estender seu ràio de ação aos pequenos centros urbanos e à zona rural da área, desenvolvendo, inclusive, um pequeno comércio atacadista.

As relações entre Paraguaçu Paulista, a ărea sob sua in fluência e as capttals regionais e-sub-regional (Assis), ncm sempre foram fácels em função do tipo de estradas da rede viária existente. Entretanto, através do desenvolvimento e implantação' do plano rodoviário estadual e, no caso especifico, através do PROINDE (Plano Rodoviário de Interiorização do Desenvolvimento 1972/75), o municipio vem sendo dotado de rodovias asfaltadas que - ligarão não só às capitais regionais e outros centros maiores ou menores na área, mas também facillttarão as relaçōes com o espaç 0 rural próximo.

Se de um lado a presença destas rodovias constituirá fa tor de desenvolvimento, por outro tornar-se-á fator de esvazia mento, uma vez que centros malores e melhor equipados estarão mais próximos. Contudo estes fatos jã são pressentidos e seus re flexos constituem fatores a mais a reforçar a preocupação em di namizar o comércio paraguaçuense.

Completando o quadro há a Escola Superior de Agronomia A sua presença na cidade resulta da exploração da distância das Es colas Superiores existentes na região, tipos de cursos que estas oferecem, desenvolvimento do setor agropecuário e da iniciativa tanto particular quanto administrativa local. Criada e instalada em 1974, apresentou neste ano 878 de sua clientela de procedéncia externa, inclusive de outros Estados brasileiros, com predominân 
cla do oeste paulista ( aspectos que serão tratados na função e ducacional), constituindo-se em: nova clientela: do comércio e de outras funçōes da cidade, embora com importância parcial, uma vez que a Esçola encontra-se em fase de implantação.

Durante o ano de 1974 o setor comercial de Paraguaçu Paú lista realizou um valor de vendas de aproximadamente $117 \mathrm{mi}$ thões de cruzeiros. Considerando-se os diferentes ramos da ati vidade: comercial, verifica-se que o mais expressivo volta-se ao atendimento da produção agropecuária, apresentando uma participa ção naquele valor total de vendas de 38,538. Seguem-lhe o comér cilo voltado às necessidades băsicas da população rural e urbana / com 37,798 e comércio de bens de consumo durável - 21,438. Os valores completam-se com os mais variados tipos de atividades que apresentạm uma participação de apenas 2,258. (Tabela 10 ).

Comércio paraguaçuense: valores totais das vendas; valores das vendas por atividade comercíl; participaçöes percentuais.

Faraguaçu Paulista - 1974

Tabela 10

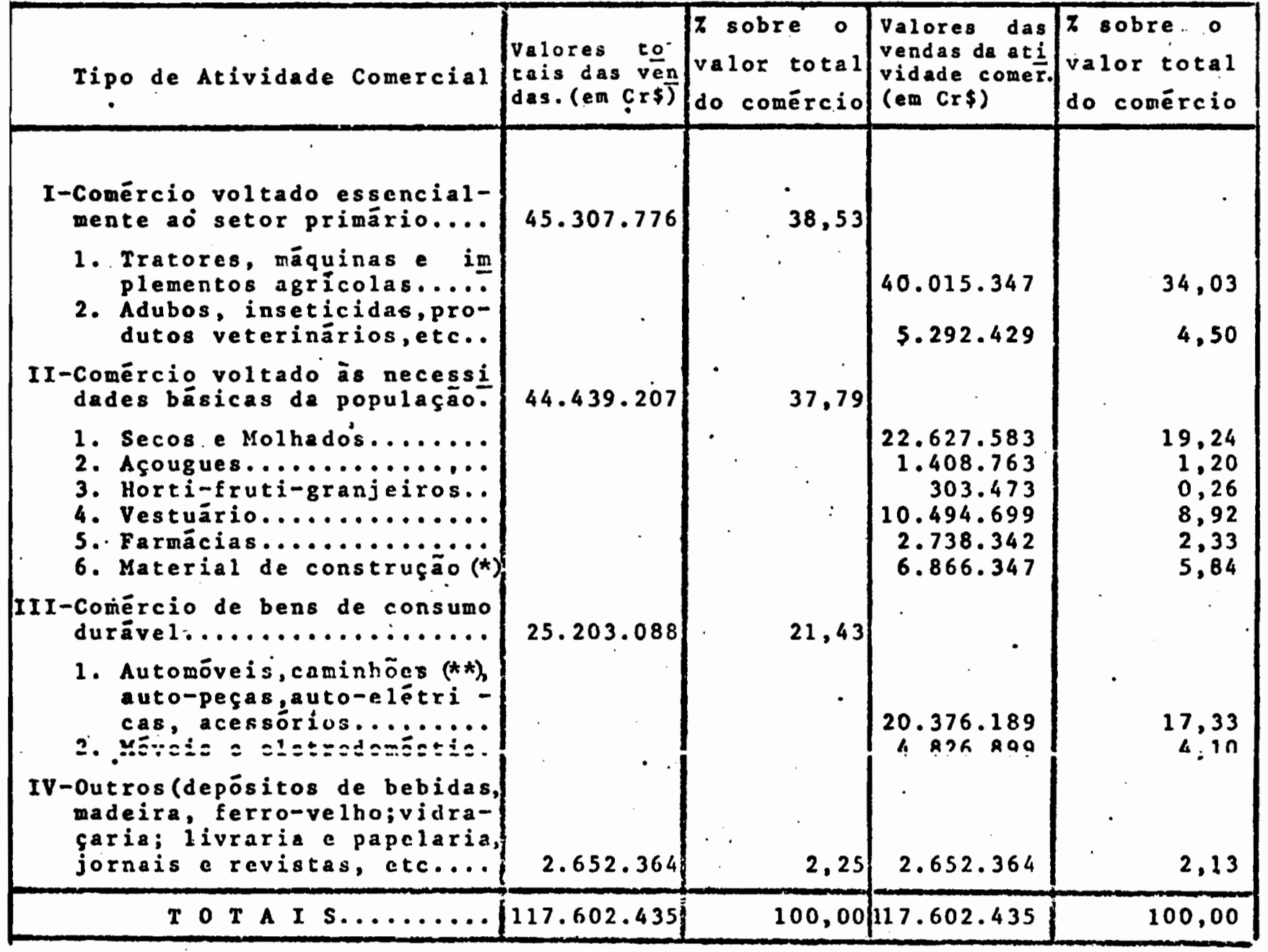

Fonte:- Modelos "B" para cálculos de índices do ICM

(*) Embora constitua bem de consumo durácl, aqui se inclue por constituir-se necessidade básica da população - alojamento, habitação.

(**) Foram incluidos nesta atividade comercial por não ser possível dissociā- lus em termos de valores (caminhöes). Entretanto através "de informaçöes inferiu-se para estes, $10 \%$ do valor do item. 


\subsubsection{Origem dos Capitais}

Atravēs de informações obtidas em 35 firmas entrevistadas verificou-se que 91,58 dos capltais são de iniciativas locais, cabendo aos de origem externa 8,58 .

Destas iniciativas locais, 68,78 originam-se de imigran tes ou descendentes destes: japoneses, espanhóis, 1talianos, por tugueses, sirios, austríacos e libaneses. Os restantes 31,38 são provenientes de paulistas, minelros e nordestinos. ( Tabe la. 11 ).

Os capitais originam-se em 258 do setor primārio, 12,58 do secundário e 65,68 do terciário de comércio. (Tabela 11).

Os comerciantes oriundos do primário foram, neste setor , pequenos proprietários rurais $(55,58)$ ou arrendatários $(44,58)$, que vendendo a propriedade ou acumulando um pequeno capital como "Inquilino da terra", transferem-se para a cidade e iniciam a no va atividade.

Aqueles provenientes do secundārio trabalharam nà fäbrica de óleos vegetais $(50,08)$, tipografia $(25,08)$ ou em indústria pau listana $(25,08)$. Com a experiência obtida, indenização e economi as, montam a atividade comercial. Do terciário de comércio a ma lor parcela cabe aos comerciários $(53,18)$, cujas atividades fo ram exercidas no mesmo ramo no qual hoje são proprietários, como viajantes $(17,68)$, empregados $(41,28)$ ou junto a estabelecimentos de parentes $(41,28)$. Experiência no ramo, empréstimos, financia mentos de estoques, pequenas economias, sucedendo o pai ou auxi liado pelo irmão, constitui o mecanismo que os leva a comercian tes. Os 9,48 que completam o grupo de capitais orlundos do ter ciārio de comércto, e composto por pessoas que iniciam na cidadeco mo comerciantes. Parcela destes jā exerceram a atividade ante riormente, encerrando-a, com posterior retomada, utilizando para tanto, em parte, o capital obtido com a venda do estabelecimento anterior. 


\begin{tabular}{|c|c|c|c|c|c|c|c|c|c|c|}
\hline \multirow{4}{*}{$\begin{array}{l}\text { Nacionalidade } \\
\text { ou descendên } \\
\text { cia }\end{array}$} & & & \multicolumn{4}{|c|}{$A T I V I D A D$} & \multirow{2}{*}{\multicolumn{4}{|c|}{$\frac{A N T E R \cap R}{T E R C I A R O}$}} \\
\hline & & & \multirow{2}{*}{\multicolumn{2}{|c|}{ PRIMAR IO }} & \multirow{2}{*}{\multicolumn{2}{|c|}{ SECUNDÁRIO }} & & & & \\
\hline & & & & & & & \multicolumn{2}{|c|}{ Comerciário } & \multicolumn{2}{|c|}{ comerciante } \\
\hline & abs & 7 & abs & $\%$ & abs & $\%$ & abs & 7 & abs & $\pi$ \\
\hline $\begin{array}{l}\text { Japonesa } \\
\text { Espanhola } \\
\text { Italiana } \\
\text { Portuguesa } \\
\text { Siria } \\
\text { Austriaca } \\
\text { Libanesa }\end{array}$ & $\begin{array}{l}5 \\
4 \\
4 \\
3 \\
3 \\
2 \\
1\end{array}$ & $\begin{array}{r}15,6 \\
12,5 \\
12,5 \\
9,4 \\
9,4 \\
6,2 \\
3,1\end{array}$ & $\begin{array}{l}2 \\
1 \\
1 \\
- \\
- \\
- \\
-\end{array}$ & $\begin{array}{l}40,0 \\
40,0 \\
25,0 \\
= \\
= \\
=\end{array}$ & $\begin{array}{l}1 \\
- \\
- \\
1 \\
-\end{array}$ & $\begin{array}{c}20,0 \\
- \\
- \\
\overline{3} 3,3 \\
-\end{array}$ & $\begin{array}{l}2 \\
2 \\
3 \\
3 \\
1 \\
2 \\
1\end{array}$ & $\begin{array}{r}40,0 \\
60,0 \\
75,0 \\
100,0 \\
33,3 \\
100,0 \\
100,0\end{array}$ & $\begin{array}{l}- \\
\overline{1} \\
\overline{1} \\
\overline{-}\end{array}$ & $\begin{array}{c}\overline{20,0} \\
\overline{-} \\
33,3 \\
\overline{-}\end{array}$ \\
\hline $\begin{array}{l}\text { Paulista } \\
\text { Mineira } \\
\text { Nordestina }\end{array}$ & $\begin{array}{l}4 \\
3 \\
3\end{array}$ & $\begin{array}{r}12,5 \\
9,4 \\
9,4\end{array}$ & $\begin{array}{l}1 \\
2 \\
1\end{array}$ & $\begin{array}{l}25,0 \\
66,7 \\
33,3\end{array}$ & $\begin{array}{l}1 \\
1 \\
-\end{array}$ & $\begin{array}{c}25,0 \\
33,3 \\
-\end{array}$ & $\frac{2}{1}$ & $\begin{array}{l}50,0 \\
\overline{3} 3,3\end{array}$ & $\overline{-}$ & $\overline{-}$ \\
\hline I 0 t a i s & 32 & 100,0 & 8 & 25,0 & 4 & 12,5 & 17 & 53,1 & 3 & 9,4 \\
\hline
\end{tabular}

Fonte: Entrevistas, por amostra gem $-1973 / 74$.

As iniciativas locais definem-se principalmente para os secos e molhados $(53,0 \%)$, havendo dispersão para os demais ramos comerciais.

Assim, segundo a descendência e o ramo optado, temos o se guinte quadro:

Origem do capital - urbano ou rural - e atividade comercial ora definida, segundo nacionalidade ou descendência de seu proprietārio.-

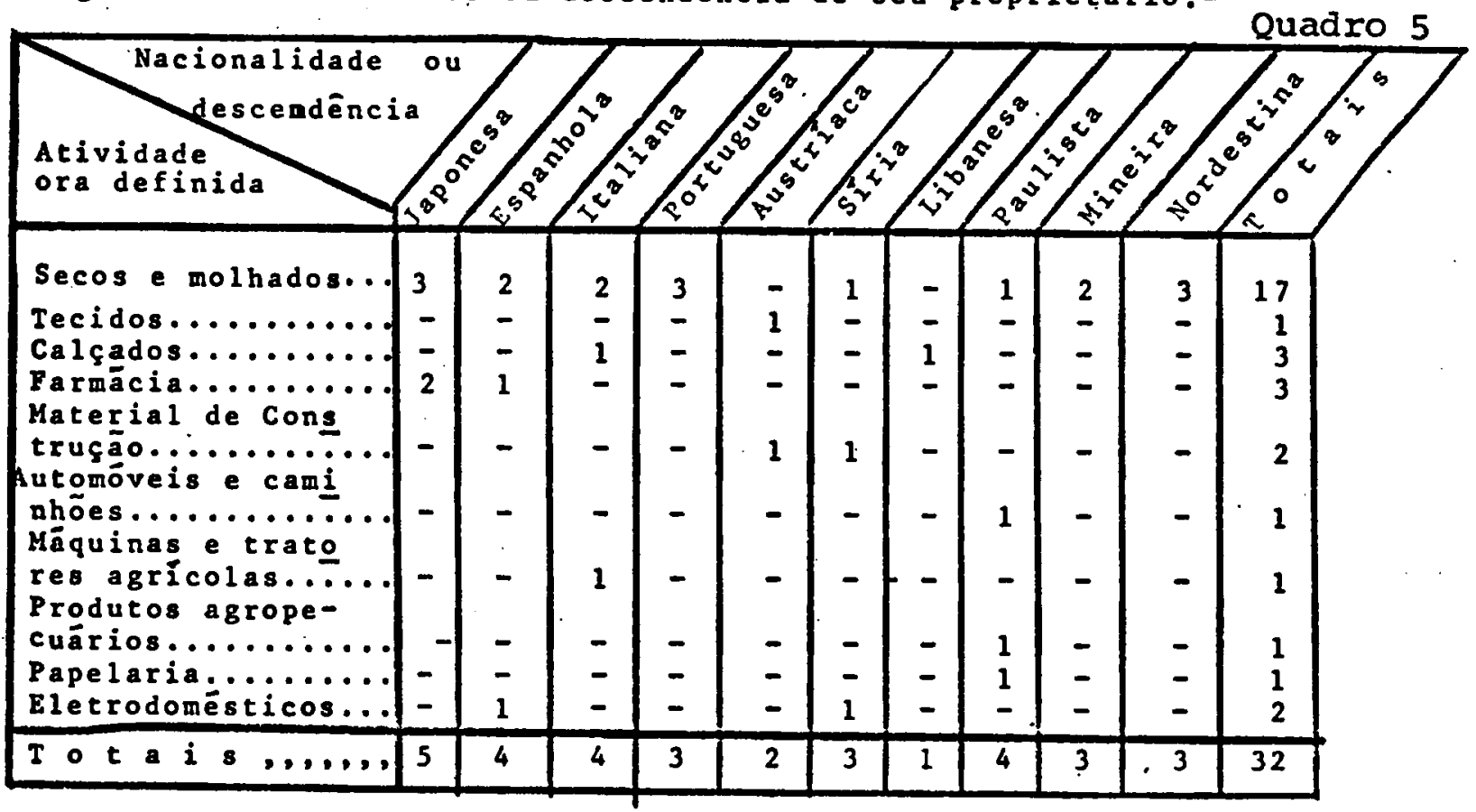

Fonte: levantamento por amostragem - $1973 / 74$. . $^{\circ}$ 
Os capitais externos estão representados pelas fillais de firmas sediadas na Alta Paulista ( Pereira Alves e Cia., Pompéia - Supermercados); Alta Sorocabana (Brasimac, Presidente Pruden te - Eletrodomésticos e móveis) e capital paulista ( Casas Per nambucanas - tecidos).

Alguns exemplos suscintos serão dados para melhor configu rar os fatos citados.

a) I. D. e Cia. - Comércio de tratores, máquinas e imple mentos agricolas. A firma I.D., constituída em 1961, tem suas origens remontando ao ano de 1951, quando: progenitor dos atuais proprietários instala na cidade' pequena casa de auto-peças, tendo a lado oficina mecâ nica para consertos em geral. M.D. era filho de imi grantes italianos que se fixaram em Sertanópolis ( PR) com propriedade cafeicultora. Face às relaçóes existen tes entre aquela àrea paranaense e Paraguaçu Paulistă, transfere-se para esta última, trabalhando na conces sionária Ford onde, em 1950, exercia as funçôes de gê rente de vendas e mecânico chefe, experiência que lhe vale para o início dos negócios. Em 1958, já com a pre sença dos filhos, passa a ser concessionário da Vemag -Veículos e Máquinas Agrícolas S/A., distribuidora dos veículos DKW e tratores Massey Harris. Posteriormente torna-se concessionário Volkswagem, transferindo-a em 1969 e permanecendo apenas com a Massey Fergusson.

Nos primeiros anos da atual década, suas vendas, essen cialmente tratores e implementos agricolas, orientam- se para a zona rural próxima abrangendo os municípios de Maracaí, Cruzália, Quatá, Lutécia, Borá e Rancharia, instalando nesta ültima escritório de.vendas.

Em decorrência da expansão dos novos produtos agríco 1 as, a firma amplia seu räio de atuaçáo, abrindo fili al em Assis (1972) e escritório de vendas em Palmital (1974). Nesta nova fase inclue nas suas vendas as co lhedeiras e outras pequenas máquinas, que serão menció nadas adiante.

Atualmente, com esta organização, distribuem estes pro dutos de Palmital a Rancharia, constituindo-se, em or dem de importância, no terceiro revendedor Massey fer gusson no Estado Paulista.

Em 1974, a sua participação nos valores das vendas do comércio paraguaçuense correspondeu a 29,51\%, ind epen te da filial de Assis que juntamente com os escritórios de vendas de Palmital e Rancharia têm valores de vendas 20* superiores à matriz.

A firma, ao lado das atividades rurais $\because$. desenvolve atividades primārias, com propriedades voltadas princi palmente à pecuária criatória. Estes aspectos serãovis tos quando se tratar da função de residência de proprietários rurais.

b) Casa M. - Firma com vendas dos mais variados gêneros armas, muniçōes, arames, material elétrico, alumínio, ferragens, encerados, etc. - mas basicamente secos emo lhados. Seu proprietário, descendente de italianos, nas 
ceu em Tietê (SP) onde seus pais eram lavradores. Nó início da década de 1930 transferem-se para Paraguaçu' Paulista, permanecendo na atividade primária, atividade esta que F. M. exerce entre 1940 e 1945. Nesta data ins tala-se na cidade e com suas economias e em sociedade com parente, adquire estabelecimento comercial, cujas origens remontavam aos primórdios da cidade.

Permanecendo com a mesma linha de produtos - armas, mu niçōes, pequenos arados de tração animal, arames, moen das, outros utensilios de uso rural, ferragens, secos e molhados - continuam atendendo a uma clientela forte mente rural.

A patir do final da década de 1950, com acentuação do esvaziamento populacional da zona rural e crescimento' da população urbana, as suas vendas passam a dirigir sesmais a esta última.

Após 1970 , ante às novas perspectivas económicas que surgem no município e áreas próximas, a espírito de iniciativa objetivando o aumento de suas vendas e aproveitando-se da posição da cidade nos limites das nas de influência ja citadas, amplia seu ráio de açao tornando-se um pequeno atacadista (1971).

Atualmente (1974), respondendo por $16,3 \%$ do valor das vendas dos secos e molhados do comércio paraguaçuense, atua em uma faixa do rio do Peixe ao Paranapanema, partir dos centros onde a influência das capitais regi onais começam a atenuar-se - Rancharia, Joäo Ramalho, Quatá, Nantes, Iepé e Gardênia, no espaço comandado por Presidente Prudente; Boră, Lutécia, Oscar Bressane, E chapora, Florínea, Maracaí, Pedrinhas, Cruzälia, no es paço marilense.

c) Casa B. - Ramo comercial de tecidos. Seu proprietário; descendente de imigrantes austríacos e italianos, nas ceu em Sāo Fidélis (RJ), onde seus avōs se fixam inici almente com pequena propriedade policultora. Posterior mente seu pai exerce as atividades de comerciante (se cos e. molhados) e de trabalhador na construção de eś tradas de rodagem, na mesma cidade fluminense, transfé rindo-se para o Estado do Espirito Santo (1932) com es ta última função. Em $1937^{\circ}$ transferem-se para Martino polis (SP) onde, como funcionário municipal, permanece na conserva de estradas, atividade que também será exer cida junto à prefeitura de Quatà (SP), durante os anos de 1938 e 39.

A primeira atividade de J.E., proprietário da Casa B., verifica-se em Martinópolis e Quatá, sendo esta a mes ma do pai. Entre 1940 e 1942 , deixando a atividade pü blica municipal, torna-se trabalhador rural e posteri= ormente mascate, através das quais amealha o pequenoca pital que origina sua primeira loja em Paraguaçu Paulis ta (1942). Suas instalaçöes são bastante modestas, em prédio àlugado, e com estoque variado-: tecidos, cha péus, miudezas (botóes, linhas e outros aviamentos pa ra pequena costura). A partir de 1947, paralela a es ta atividade instala pequena relojoaria, transferindo= a em 1951 para un parente.

Permanece modestamente até 1973, embora houvesse adqui rido pequena propriedade rural e imóveis urbanos, quan do diante das novas pérspectivas comerciais que se apre sentavam desde o início da década, com o desaparecimen 
to de concorrentes (Casas Buri, Lojas Riachuelo, Casas Jaraguá), fatos estes ocorridos na década anterior co mo jầ se viu, e à sua iniciativa, deixa as pequenas ins talaçôes iniciais, já de dua propriedade, remodelando ${ }^{\top}$ sua linha de vendas e estoque (tecidos e confecções). Em 1974 deteve $35 \%$ do comércio de tecidos e confeç̧öes da cidade; sendo apenas superado pelas Casas Pernambuca nas (53\%). Nesta última fase seu räio de ação amplia= -se. Além de Paraguaçu Paulista, atende: Quatá, João Ramalho, Oscar Bressane, Lutécia - tanto à zona urbana quanto à rural.

d) Casa N.S.A. - Comércio de materiais para construção. o atual proprietário, nascido em Paraguaçu Paulista, é descendente de imigrantes austriacos, fixados inicialmente em Nuporanga (SP) como empreiteiros de lavourade café. Posteriormente transferem-se para o município pa raguaçuense onde adquirem propriedade rural dedicada à agricultura e criação. Em 1950 transferem-se para a cidade e com o capital originado da venda desta propri edade, iniciam a atividade comercial - pequeno empório. M. S: sucede o pai nos negócios (1961) onde já auxilia va desde a sua instalação. Através de sua iniciativa 7 constrói suas instalaçoes, amplia e estoque e vendas, permanecendo no ramo de secos e molhados até $1972 / 73$ i. quando, face à expansäo da construção civil na cidade ( 18$)$, substitui gradativamente seu estoque, constitu indo atualmente comércio de materiais de construção $/$, cujos valores das vendas, em 1974, representaram $35 \%$ dos valores totais das vendas do ramo comercial cm pa raguaçu Paulista.

e) Supprmercados P.P. - A firma P. A. e Cia, de proprieda de de imigrantes portugueses, surge na Alta Paulista = Pompéía (SP) - com a instalação de pequeno armazém de secos e molhados (1940). Alguns anos mais tarde (1948), iniciam o ramo atacadista, expandindo-se ao longo da década de 1950, têtro, no início da década seguinte, raio de ação alcançando a Alta Paulista (a partir de Marília) Nororeste (a partir de Penāpolis) e Alta Sorocabana.) Apōs o primeiro lustro da década de 1960, com o objeti vo de abandonar gradativamente o setor atacadista, ins tala seu primeiro supermercado em Dracena (1965). Segui damente abre as lojas 2 e 3 em Pompéia, sede da firma. Embora com as três lojas em funcionamento, permanece, em meinor escala, com a atividade atacadista, cuja pre sença em Paraguaçu Paulista ocorre até o final de $197 \overline{3}$. quando ai instala a loja 4 (quatro). Esta surge ao 1 a do do objetivo primeiro jā mencionado, pelo aparec $\bar{i}$

( 18 ) Em 1970 o número de plantas aprovadas pela prefeitura muni cipal foi de apenas 3 (três); em 1971 - 3 (três); em $197 \overline{2}$ 22 (vinte e duas); 1973 - 47 (quarenta e sete); $1974-68$ (sessenta e oito) e 1975, até o mês de outubro, - 120 (cen to e vinte). 
mento na cidade de pequenos supermercados que deixam de constituir-se seus clientes, uma vez que pelas condiçōes oriundas deste tipo de comércio (melhor preço, esto ques, etc.), compram diretamente das industrias; peló sistema de vendas que efetuavam oferecendo prazos geral mente maiores que seus concorrentes acarretando reten çäo de parcela do capital de giro; pela inexistência dé estabelecimento de médio porte do gênero supermercado,o que significava, consequientemente, pequena concorrência; pela presença de uma clientela em potencial que se abas tecia nos pequenos e médios estabelecimentos supridospe 1 a sua atividade atacadista; pela melhoria das condiçóes econômicas do município e área próxima, refletidas na relativa expansão do comércio paraguaçuense - constituem fatos que os levam à instalação da loja na cidade.

Um ano após a sua instalação (1973), os valores de suas vendas representaram $20,7 z$ dos valores das vendas do ra mo de secos e molhados do comércio paraguaçuense.

\subsubsection{Contrôle e Gestão}

Quanto ao controle e gestão do comércio, considerados os valores das vendas para 1974, observa-se que 51,358 são"mistos", 40,958 são locais e 7,708 externos (Tabela 12 ).

o primeiro aspecto (misto), está assim caracterizado por estar diretamente afeto às concessionärias e distribuidoras, as quais têm firmas e capitais iniciais originados localmente - já vistos pelos exemplos citados - mas cujo comércio dos produtos a serem distribuidos se faz mediante contrato e fiscalização da em presa produtora, constituindo-se o concessionário um "sócio ven dedor" da mesma, onde a participação deste ocorre apenas nesta ' etapa final do processo industrial.

Contrồle geatäo do Comércio Paraguaçuense, segundo setores de atividades comierciais

Paraguaçu Paulista - 1974

Tabela 12

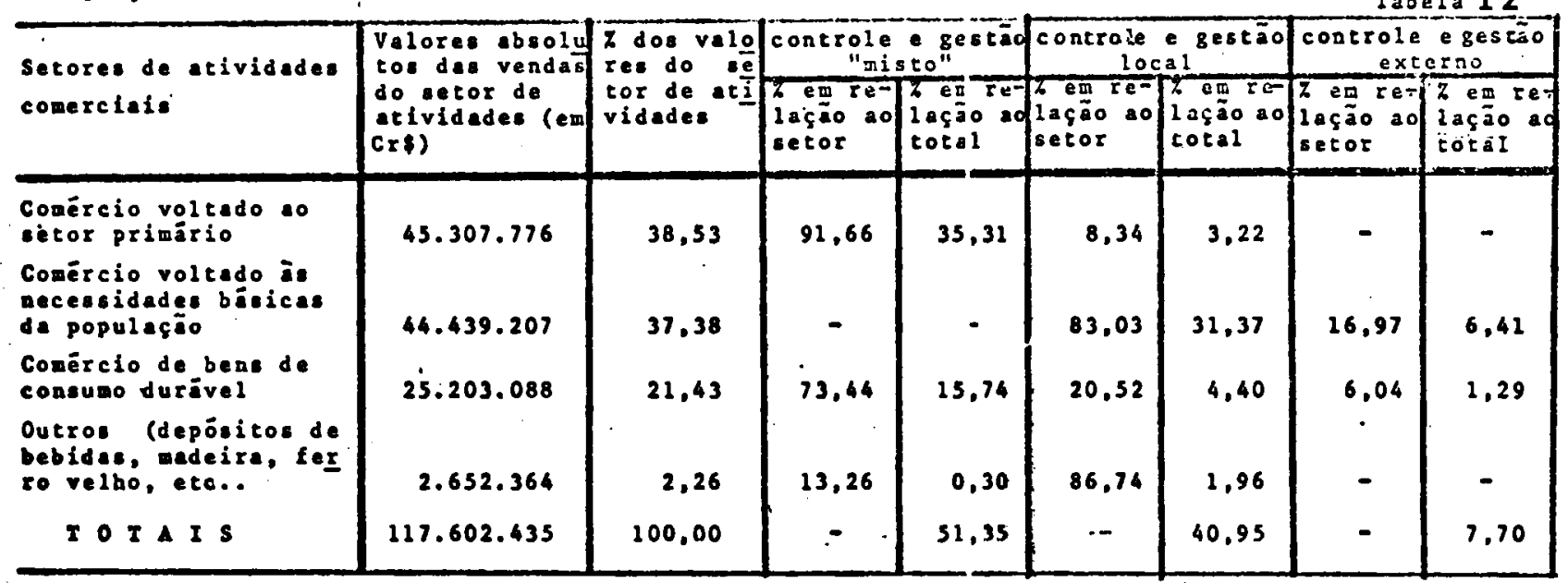

Tonta: Nodêlos "B" des Declaraçöes de Dados Informativos Necessarios à apuração dos Indices de Participação dos truai cíplos Paulistas no-Produto da arreeedaçao do ICX. - P.Paulista - 1974.- 
Tomados os setores de atividades e considerando-se a auto nomia do comërcio paraguaçuense, face ao controle e gestão, defí nidos na Tabela 12 , temos:

a) semi-autonomia do setor comercial voltado essencialmen te ao atendimento das atividades primárias, uma vez que - controle e gestão do mesmo é dominantemente misto.

Esta dominação é exercida pela concessionāria de trato res, măquinas e implementos agricolas, onde apenas uma delas, já citada, representa 88,878 dos valores das ven das do setor.

b) Nas atividades comercials voltadas às necessidades bạa sicas da população, hã forte autonomia, tendo-se em conn ta que o seu controle e gestão são essencialmente 10 cals: Os 16,978 de controle e gestão externa definem' à primeira vista, pequena dominação de fora. Entretanto êste aspecto torna-se sensivel e marcante ao nivel de ramos comerciais. Assim, a presença externa è definida por duas firmas onde uma delas participa com mais de 508 das vendas dọ ramo de tecidos e confecções, enquan to que a outra obteve mais de 208 das vendas do ramode secos e molhados.

c) No setor de atividades comerciais voltadas aos bens de consumo durāvel, hā a autonomia, semi-autonomia e a pre sença externa. Os altos valores das vendas das conces sionárias da indústria automobilistica (Ford, Vw e Che vrolet) refletem de forma marcante a semi-autonomia do setor. A razoável autonomia é essencialmente resultado do comércio de móveis e eletrodomésticos $(13,128$ do se tor), ramo este em que duas firmas participam com mais de 568 dos valores das vendas.

d) No setor "outros", pela pouca expressividade da partí clpação no comércio local, participação esta que se pul veriza nos pequenos valores e estabelecimentos em dife rentes ramos de atividades, hã autonomia marcante. A semi-autonomia existente é caracterizada pela presença de lojas distribuidoras de gás e depósito distribuidor de bebidas skol e Brahma:

Portanto, a automomia do comércio paraguaçuense está for temente ligado às necessidades básicas da população, onde a major 
ou menor expressão è ditada pela ordem das necessidades desta. Como exemplo, pode-se citar o setor habitacional, onde a expan são da construção civil criou condições para o deslanche do comér clo de materiais de construção, Inclusive competindo com centros maiores prōximos, o que significa maior grau de autonomia desta' atividade.

A semi-autonomia caracteriza-se em setores de "atividades onde o controle e gestão da produção originam-se não apenas de empresas nacionais, mas também, e principalmente, daquelas de âm bito internacional - Indústrias de măquinas, tratores, implementos, insumos, veiculos, etc. - cujas unidades brasileiras const $\underline{i}$ tuem filiais ou divisões de matriz sediadas no exterior. A pre sença destas no comércio paraguaçuense, tanto as de nível inter nacional quanto nacional, constituem apenas um estabelecimento a mais de sua grande rede distribuidora, no qual embora o capital seja local, a sua responsabilidade e interesse expréssam-se na maior presença do produto no mercado, assistência permanente e segurança na distribuição, representados pelos concessionários.

o controle externo è observado em dois setores: necessida des básicas da população e comércio de bens de consumo durável e nestes em três ramos comerciais: secos e molhados, tecidos e móveis e eletrodomésticos.

No primeiro ramo de negōcios a presença externa é resultą do da mudança dos objetivos da firma quanto à forma de distribui ção dos produtos dentro de uma áreaconde jă se fazia presente co mo atacadista. Dentro desta nova diretriz, procurando manter 0 mercado paraguaçuense, consequientemente pequena parcela da Alta Sorocabana, na esfera de seus negócios, al instala uma de suas lo jas.

No ramo de tecidos, as origens do capital externo em Para guaçu Paulista remontam a 1933, data em que as Casas Pernambucanas abre na cidade uma de suas filiais. Portanto este controle' externo neste ramo de negócios do comércio paraguaçuense é feito através de grande organização comercial, cujos interesses são de ordem nacional.

No setor de bens de consumo durável a presença externa é exercida através de uma das filiais de organização comercial de carāter regional, sediada em Presidente Prudente. A sua implantạ ção em Paraguaçu Paulista (1968) decorre do interêsse da organização, na epoca, em estabalecer um domínio neste ramo comercial em toda a Alta Sorocabana. A sua preocupação constitui-se en ga 
nhar parcela dos mercados locais, concorrendodiretamente com as firmas do lugar e ao mesmo tempo dificultar a entrada de outras de porte semelhante ou maiores, não só em Paraguaçu Paulista, mas em toda a região.

\subsubsection{Abastecimento do Comércio}

o abastecimento do comércio paraguaçuense deversifica-se quanto aos centros fornecedores, onde são Paulo (capital) tempre sença muito forte.

o comércio voltado ao setor primário abastece-se através das indústrias paulistanas, do interior paulista ou de outros Es tados - Paraná e Rio Grande do Sul.

Quanto às máquinas; tratores e implementos agrícolas, os quais têm na Concessionária Massey Ferguson o seu grande peso, provêm. da capital paulista (708 representados pelos tratores) e do Estado do Rio Grande do Sul (258 - colhedeiras e implementos' agrícolas), onde a citada indústria tem suas făbricas. Além des tas há Implementos agrícolas, pequenas máquinas para lavoura, pre paração de rações, que são produzidas em outros centros paulistas (Matão, Pompéia) e que demandam ao comércio paraguaçuense.

Casas agropecuárias, comércio de inseticidas e adubos têm os produtos provenientes principalmente da capital paulista, do interior (calcāreo - Depressão Periférica Paulișta, principalmen te) e Norte do Paraná (Ibiporã)..

Os de secos e molhados abastecem-se, com certa ordem de im portâncla, atravēs de são Paulo (capital), Bauru, Marília, :Our nhos, Tupã, Pompéia.

A presença paulistana define-se pela distribuição ou atua ção direta das indústrias, enquanto que os demais centros citados possuem não só os depósitos, entropostos de indústrias paulistas e de outros Estados, cujo exemplo principal è Bauru que distrị bui produtos SANBRA, Anderson \& Clayton, Matarazzo, Nestle, etc., bem como as filiais ou sedes de firmas atacadistas (Dias Martins, J. A. Veríssimo, Pereira Alves, G. Moreira, etc..).

Este abastecimento se faz através da presença de viajan tes em intervalos curtos de.tempo (quinzenalmente, o mais comum), entrega razoavelmente rápida e quase que totalmente rodoviária (90 a 958), ao lado de oferta de prazos de pagamento, o que faci lita o giro do capital, de grande importância para o pequeno e médio comerciante, predominantes em Paraguaçu Paulista.

Alēm do grosso dos produtos, principalmente industrializa 
dos, adquiridos nas cidades e formas anteriormente citados, par cela menor è obtida em outros centros paulistas, outros Estados, na área prōxima e mesmo localmente.

Quanto aos Estados destacam-se oparanā e Mato Grosso, que constituem fonte de abastecimento direto de cereais, adquiridos' pelos próprios comerciantes ou via máquinas de beneficiamento lo cais, ou ainda, pela presença de "mercadores ambulantes" e "mar reteiros" na cidende.

A área próxima fornece farinhas (mandioca - Candido Mota), açúcar. (Maracaí, Quatã), bebidas (aguardente, bebidas não alcólí cas - Assis). Localmente são obtidos parte dos cereais, farinhas (milho e mandioca), café, bebidas (aguardente e não alcólicas).

Os produtos famacêticos procedem principalmente de ata cadistas, dos quais hã a presença marcante da Drogasil - perto de 608 do abastecimento das farmácias paraguaçuenses - através de suas filiais de Presidente Prudente (388), Ourinhos (158) e Marília (78). Além desta e com pequena expressão hã a Distribui dora Irmãos Queirōz, de Lins (28). Os quase 408 restantes do abas tecimento são feitos através de laboratōrios com as vendas dire tas por intermédio dos viajantes.

Em ambos os casos, atacadistas e laboratórios, o atendimen to é feito pela presença semanal, quinzenal ou mensal dos viajan tes, contudo, o mais regular, constante e com intervalos mais curtos, é oferecido pela Drogasil. As entregas são rápidas e em 958 rodoviārias.

Os tecidos provêm., em ordem de importância, da capital ' paulista (75\%). Americana (SP) (108), Sorocaba (58), Campinas e Jundiaí. A presença marcante da capital paulista resulta do domí nio neste setor comercial paraguaçuense das Casas Pernambucanas' (538), que atraveś de sua central paulista adquire produtos das. mals diferentes fábricas brasileiras e os redistribui para as filiais. Completando a presença da capital paulista, a firma io cal - Casa Botafogo - que controla 358 do comércio de tecidos e confecções, tem $60 \%$ de seu abastecimento provenientes de indús trias daquela cidade.

As confecções provêm. em grande parte do Nordeste 160 \& Confecções Guararapes, Torres, Saronord), e em menor proporção de São Paulo ( 35 \&) com vârias indústrias, e Santa Catarina ( 58 Artex e Hering).

Exceto as Casas Pernambucanas, que efetuam transferências dos produtos de são Paulo (depósito central) para a filial para 
guaçuense, as demais tem o abastecimento feito através de viajan tes, principalmente das fábricas. Apenas pequena parcela de co merciantes compra diretamente das indústrias ou distribuidores / paulistanos, principalmente confeç̧ões e roupas feitas.

Neste setor verifica-se uma ligeira vantagem para o trans porte rodoviārio (558) em relação ao ferroviário (458), para en tregas.

Os calçados têm proveniência bem definida: Rio Grande do Sul - 608 - e Estado de São Paulo - 408 (Franca 258, Birigui 108 e são Paulo 5\%) -. As compras são feitas essencialmente pela pre sença de viajantes. O tramsporte utilizado é 1008 rodoviārio pa ra os produtos paulistas. As remessas do Rlo Grande do Sul uti $11 z$ am a ferrovia em 608 .

o ramo de materiais de construção tem o seu abastecimento feito essencialmente pelas indústrias ou depósitos e fillais de Indústrias paulistas ou de outros Estados, localizadas na capi tal paulista, Presidente Prudente, Bauru, Assis e que totalizam. 808 do atendimento. A pequena variação que surge no ramo, verifí ca-se principalmente quanto à ferragens, metais, tubos e conec ções com a presença do Rio Grande do Sul (108), Santa Catarina ( $58)$ e Rio de Janeiro (5z).

Como nos demais ramos do comércio, a aquisição dos prodū tos é feita com a presença do viajante. Por outro lado, fuginda ao comum, a ferrovia responde por 908 do.transporte.

Os automóvels e caminhões seguem o mecanismo nacional: as concessionārlas recebem diretamente das fábricas, apōs pedido quanto ao número, modelos e outras especificaçōes tēcnicas, . os veículos a serem vendidos ou jā vendidos.

Ainda neste ramo, as peças e acessórios são, na sua maio rla, provenientes das fäbricas fornecedores da Indûstria automo bilistica, mas atavés desta ültima e de acordo com o pedido da concessionária. Apenas uma pequena parcela deste ramo e o ramode auto-elētrica adquirem o seu estoque através de viajantes. Nes tes ramos comerciais, o transporte utilizado é 1008 rodoviário.

Os demais ramos do comércio paraguaçuense utilizam o meca nismo geral para o seu abastecimento, variando os centros segun do o produto adquirido, incluindo-se o centro local para certos ramos tais como açougues, material de construção (tijolos, ma deira, etc.). 


\subsubsection{Mercado Consumidor}

Através da análise das entrevistas realizadas e dos dados globais dos valores das vendas do comércio paraguaçuense obtidos pelo modêlo " $B$ " para cálculo do Indice do I C M, verifica-se que a função caracteriza-se como distribuidora de produtos. Esta dis tribuição, como se percebe pela tabela abaixo (Tabela 13 ), épre dominante de produtos industrializados (aproximadamente 858), fi cando os gêneros agrários fortemente minoritários (15\%).

A cidade, embora apresente maior clientela, participa com aproximadamente 408 dos valores das vendas do comércio, enquanto queàs zonas rurais municipal e vizinhas, cabe uma participação' próxima dos 528 (Paraguaçu Paulista 19,58 e áreas vizinhas 32,78). Aos centros urbanos vizinhos cabe um percentual de apenas $5,68 \mathrm{e}$ às āreas mais distantes 2,08 (Tabela 13 ).

Esta presença externa do comércio paraguaçuense caracteriża, embora tenuemente, a ārea de dominação mais distante da função e que alcança os municípios de Quatā, Borā, Lutēcia, os car Bressane, Maracaí, Cruzália. De forma esporádica e que nãoca Facteriza dominação, algumas atividades chegam a Rancharia e Ie pê.

\begin{tabular}{|c|c|c|c|c|c|c|c|c|c|c|c|}
\hline 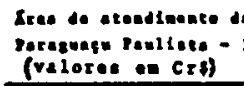 & lon ettelde & dedes cosent & aere per & 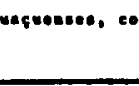 & & & & & & Tabe & 1 a 13 \\
\hline 2190 & $\begin{array}{l}\text { 2one urt } \\
\text { Paragues }\end{array}$ & $\begin{array}{l}\text { rbane de } \\
\text { qu Peulicte }\end{array}$ & $\begin{array}{l}\text { Zona in } \\
\text { Perpagus }\end{array}$ & $\begin{array}{l}\text { urel de } \\
\text { qu Paudlete }\end{array}$ & $\begin{array}{l}\text { 2. ne ru } \\
\text { ni e vu }\end{array}$ & $\begin{array}{l}\text { arel próxía } \\
\text { ntelpal }\end{array}$ & $\begin{array}{r}\text { Coatroe } \\
\text { pró }\end{array}$ & $\begin{array}{l}\text { Derbacos } \\
\text { axloos }\end{array}$ & $\begin{array}{ll}\text { ateat } \\
\text { Atuse }\end{array}$ & 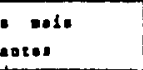 & \\
\hline$\because \ldots+c \mid a^{\prime}$ & 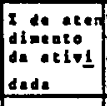 & 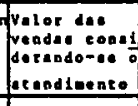 & $\begin{array}{l}\text { de aten } \\
\text { dimento } \\
\text { dadivi } \\
\text { dade }\end{array}$ & 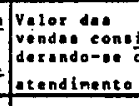 & 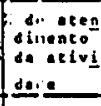 & 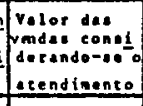 & 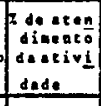 & 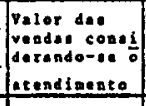 & 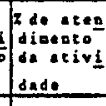 & $\begin{array}{l}\text { valor das } \\
\text { vendes coand } \\
\text { dersado-se } \\
\text { acendimeoco }\end{array}$ & $\begin{array}{l}\text { valorine tozed } \\
\text { des } \\
\text { Dudedes }\end{array}$ \\
\hline 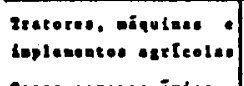 & -- & -- & & & 10 & & -- & $\cdots$ & $\cdots$ & & 40.025 .367 \\
\hline $\begin{array}{l}\text { Caece agropecuirias, } \\
\text { lacecteldes. eduboo }\end{array}$ & 10 & 329.243 & 35 & 1.832 .330 & is & 193.864 & $\cdots$ & --. & 60 & 2.116 .972 & 3.292 .429 \\
\hline lecor - molkeder & ss & 13.123 .998 & 25 & 3.656 .896 & 10 & 2.262 .738 & 7 & 1.583 .931$. & - & --- & 22.267 .583 \\
\hline Asengues & os & 1.197 .449 & is & 211.314 & $\cdot$ & --- & $\rightarrow$ & $-\cdots$ & - & --- & $\begin{array}{r}1.468 .163 \\
10.454 .699\end{array}$ \\
\hline $\begin{array}{l}\text { Vectuarte } \\
\text { Peruicles }\end{array}$ & 62 & 0.434 .240 & 24 & 2.518 .128 & $?$ & 781.102 & ; & $629: 602$ & $\ldots$ & 104.967 & $\begin{array}{r}10.454 .699 \\
2.738 .362\end{array}$ \\
\hline $\begin{array}{l}\text { Zetruiclas } \\
\text { noterial al conectug. }\end{array}$ & 62 & $\begin{array}{l}2.245 .440 \\
4.325 .199\end{array}$ & $\begin{array}{l}13 \\
11\end{array}$ & $\begin{array}{r}335.915 \\
1.304 .006\end{array}$ & 3 & $\begin{array}{r}12.130 \\
131.321\end{array}$ & ${ }_{16}^{2}$ & $\begin{array}{r}34.767 \\
1.090 .615\end{array}$ & $\ddot{--}$ & $\cdots$ & $\begin{array}{l}2.738 .362 \\
6.866 .367\end{array}$ \\
\hline Autonövele, castetöer & 6 & 13.035 .809 & 10 & 2.037 .819 & . & 1.630 .095 & 16 & 2.052 .606 & - & $\cdots$ & 80.376 .189 \\
\hline nevele. eletrodonast. & 66 & 3.105 .133 & 16 & 112.304 & 12 & 330.959 & $s$ & 241.345 & 2 & 96.530 & $6.826 .899^{\circ}$ \\
\hline Oneres & is & 2.234 .309 & , & 185.663 & -3 & 132.619 & 3 & 79.131 & - & $\cdots$ & -2.652 .364 \\
\hline Toselo & & $\begin{array}{l}47,172.240 \\
(40,212)\end{array}$ & & $\begin{array}{c}22.898 .336 \\
(19.528)\end{array}$ & & $\begin{array}{c}38.369 .132 \\
(32.712)\end{array}$ & & $\begin{array}{l}6.560 .577 \\
(5,50: 2)\end{array}$ & & $\begin{array}{l}2.318 .437 \\
(3,982)\end{array}$ & $\begin{array}{c}117.294 .962 \\
(100,008)\end{array}$ \\
\hline
\end{tabular}

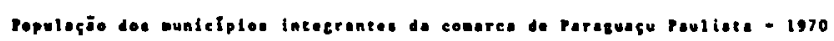

\begin{tabular}{|c|c|c|c|c|c|c|c|c|c|c|c|c|c|c|c|c|}
\hline & \multicolumn{2}{|c|}{ P. Paudletes } & \multicolumn{2}{|c|}{ Quati } & \multicolumn{2}{|c|}{ Inri } & \multicolumn{2}{|c|}{ Luticle } & \multicolumn{2}{|c|}{ Jor. Breasene } & \multicolumn{2}{|c|}{ Heracel } & \multicolumn{2}{|c|}{ Crusalite } & \multicolumn{2}{|c|}{ Totel } \\
\hline & Abs. & 2 & Abe. & 2 & Abse. & 3 & $A b_{1}$. & 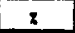 & Al.. & 2 & Abr. & 2 & Abs. & $x$ & Abs. & 2 \\
\hline $\begin{array}{l}\text { Drtane } \\
\text { Reral } \\
\text { Toetal }\end{array}$ & $\begin{array}{r}13.858 \\
0.034 \\
21.092\end{array}$ & $\begin{array}{r}63,3 \\
36,1 \\
100,0\end{array}$ & $\begin{array}{r}3.235 \\
0.346 \\
11.581\end{array}$ & $\begin{array}{r}21.9 \\
12.1 \\
200.0\end{array}$ & $\begin{array}{r}123 \\
1.167 \\
1.210\end{array}$ & $\begin{array}{r}9.7 \\
90.3 \\
100.0\end{array}$ & $\begin{array}{l}1.111 \\
3.306 \\
4.417\end{array}$ & $\begin{array}{c}21.2 \\
10.8 \\
100,00\end{array}$ & $\begin{array}{l}1.069 \\
3.130 \\
4.199\end{array}$ & $\begin{array}{r}23,5 \\
14,5 \\
100,0\end{array}$ & $\begin{array}{l}3.188 \\
3.468 \\
1.656\end{array}$ & $\begin{array}{r}36,0 \\
63,2 \\
100,0\end{array}$ & $\begin{array}{r}476 \\
7.002 \\
1.478\end{array}$ & $\begin{array}{r}6.4 \\
13.0 \\
100.0\end{array}$ & $\begin{array}{l}23.600 \\
36.633 \\
39.493\end{array}$ & $\begin{array}{r}38.0 \\
61,2 \\
1\end{array}$ \\
\hline
\end{tabular}

Tonces conoo do 1970.0 
Portanto, considerando-se as diferentes atividades, os va lores de suas vendas e para onde se voltam, constata-se que a fin ção comercial paraguaçuense está dirigida peincipalmente para o setor primário.

Tomando-se em conjunto - zona rural paraguaçuense e zona' rural próxima - verifica-se que os maiores valores das vendas do comércio seguem : a ordem da tabela 13 : máquinas, tratores e implementos agrícolas, secos e molhados, automóveis e caminhōes.

A zona rural municipal apresenta um certo equilibrio en tre os valores das vendas do comércio voltados essencialmente ao setor primārio e aqueles voltados às necessidades básicas da população, com ligeira predominâncla para este último. Em terceiro plano e bem distante estão os bens de consumo durável.

Na zona rural próxima e não municipal, os valores do co mércio definem-se predominantemente pelo consumo de produtos des tınados à produção agropecuāria. Com pequena expressão, em relação a este, seguem-se os demais ramos comerciais.

Estes fatos assim se apresentam em função da distribuição espacial da população rural, da distância que se encontra o cen tro urbano de Paraguaçu Paulista em relação às āreas rurais, à presença de outros centros urbanos nas áreas rurais não munı́cipa 1s, ao equipamento comercial existente naquele e nestes centros' urbanos,

A população maral municipal representa aproximadamente 228 da população da ārea em questão, ou seja, dos municípios de Qua tá, Borá, Lutécia, Oscar Bressane, Maracaí, Cruzália e Paraguaçu Paulista, e encontra-se mais próxima à cidade de Paraguaçu Paulis ta seja pela distância em si, seja pelas relações administrativas (séde de Comarca, Banco do Brasil, Posto de Sementes, etc..), ou pela presença das estradas que convergem do melo rural para ela. As áreas rurais próximas não municipais abrigam 788 restantes da população, havendo parcela desta que, pelas condições acima, apro xima-se do centro urbano paraguaçuense. Entretanto, o maior con tingente populacional destas āreas encontra-se mais distante des te centro e mais próximo de outros existentes na área (Tabela 13 )

o comércio voltado essencialmente ao atendimento do primā r1o, tem os maiores valores das vendas nas áreas rurais vizinhas não municipais. O fato decorre da existêncla de maior contingente populacional nestas áreas, de maior dominlo espacial de culturas que propiciam e mesmo exigem maior grau de mecanização (trigo e soja). 
Reforçando a aturşão desta atividade comercial, a indús tría mecânica voltada para a ajricultura, que no espaço em ques tão tem presença dominante através da Massey Ferguson do Brasil $S / A$, quando da distribuição dos seus setores de vendas e conces sionárias, define Paraguaçu Paulista como lugar sede de.um des tes e dota-a com concessionāria e oficina especializada. Este fato gera a ausência, no equipamento comercial dos demais pe quenos centros urbanos deste espaço setorial, de agências ou re vendedores de tratores, măquinas e implementos agrícolas ficando seu atendimento predominantemente a partir do núcleo paragua çuense.

Quanto aos produtos veterinários, inseticidas, adubos, ve rifica-se que estes chegam à zona rural muito mais pela presen ça do distribuidor, representante ou viajante junto ao homem do campo, do que pela presença deste último na cidade procurando adquirílios.

Considerando-se que não hã definição de setores por par te das Indústrias destes produtos, verifica-se que não hã o do mínio deste ramo de atividade comercial, à partir de paraguaçu Paulista, nas áreas rurais próximas ou mais distantes, embora a sua proscrọa soja marcante. O que há é à existência de uriá ăritea de ação mais livre, onde a atuação mais direta do comercianteou outros prepostos deste ou da indūstria, resulta numa concorrêncla entre Paraguaçu Paulista e os demais centros urbanos do es paço em questão, 1sto por que estes contam em seu equipamento co mercial com casas, representantes, viajantes das diferentes fä bricas de inseticidas, adubos e produtos veterinários,

os valores do comércio voltado às necessidades bāsicas da população são maiores na zona rural paraguaçuense , explicados através daquela proximldade. A presença destes ramos de co mércio arrefece nas áreas rurais que se distanciam, na medida em que aquelas populaçōes contam com a presença de outros centros urbanos que lhes são mais próximos. Os ramos mais expressivos ' deste comércio na zona rural paraguaçuense e áreas rurais prō ximas são os secos e molhados, vestúario e material de constrú ção. (Tabela 13 )

o essencial do consumo urbano constitui-se nos produtos destinados às necessidades bāsicas da população, seguidos dos bens de consumo durável.

No atendimento à população urbana quanto às suas neces 
sidades bāsicas observa-se, atravēs da Tabela 13 , que as atí vidades comerciais mais preponderantes constituem $\circ$ açougue e a farmācia No primeiro caso, a zona rural possui condiçōes de sú prir-se em suínos, aves, de acordo com as suas necessidades, pro curando a cidade para obter carne bovina, mais acentuadamente a carne seca. No segundo, o homem rural procura menos o centro ur bano. Utiliza-se dos remédios "caseiros", benzimentos e quando procura a farmácia o faz em função da gravidade do mal, tendo an tes passado pelo médico e, ainda neste caso, adquire apenas o in dispensāvel da receita, ou pela confiança que tem no farmacêuti co, poupando-lhe a consulta médica e indicando o necessārio. Es te último aspecto é mais comum para pequenos males.

Nos demais ramos o atendimento permanece urbano mas com a presença mais constante do homem rural na cidade que consome, tal qual o citadino, os secos e molhados, vestuário e materiais de construção. Esta presença origina-se das transformações ocor ridas na sua organização econômica, isto é, atualmente volta-se mais às produções de economia de mercado, reduzindo o espaço de dicado às culturas para seu consumo e o tempo de que dispunha / tanto para as culturas em.si, quanto na tránsformação destas , principalmente em alimentação e vestuário. Complementando estes fatos, o espaço rural deixa de oferecer , pelas suas próprias ' condições, matērias-prímas para a construção da habitação. As sim, o homem rural se vê obrigado a adquirir em proporções cada vez maiores, e quase sempre mais caros, estes produtos no comér cio da cidade.

Da mesma forma, o comércio de bens de consumo durāvel a tende em maior escala o centro urbano. A zona rural procura-o na cidade pelo fato de que esta constitui, obviamente, a redistribuidora destes produtos.

Complementando estas observações quanto ao atendimento do. comércio paraguaçuense, há que se mencionar a presença, neste , dos centros urbanos mais próximos. Esta presença é mais acen tuada nos ramos de materiais de construção e automóveis e cami hhões. Isto ocorre porque o equipamento comercial destas cida des, todas menores que Paraguaçu, não possui casas ou agèncias' distribuidoras destes produtos. 


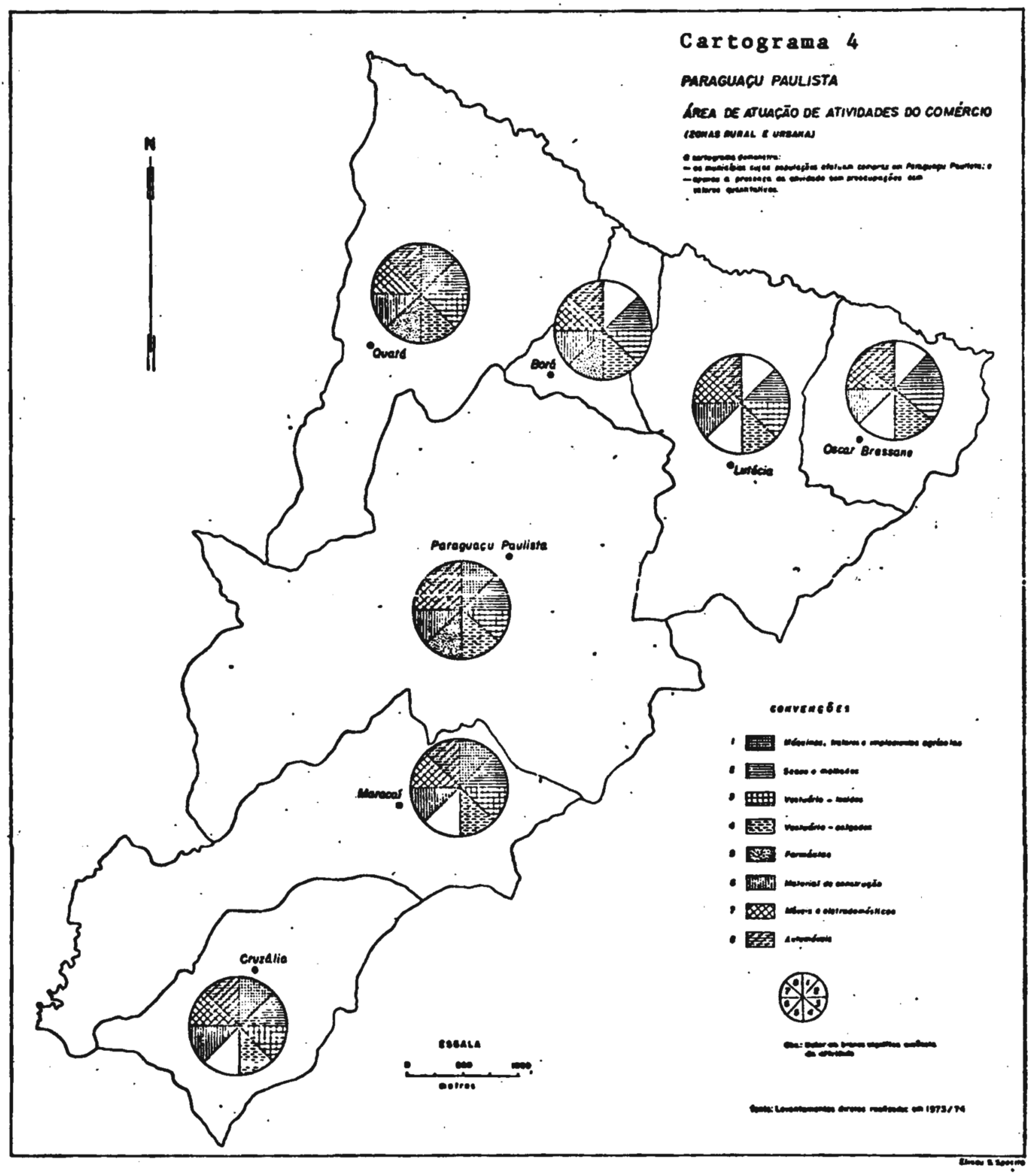




\subsubsection{A Função de Serviços}

Os serviços estão representados na cidadde por atividades que envolvem quase duas centenas de estabelecimentos e diversos profissionals liberais, cujas presenças alcançam desde uma área que extravasa pouco alēm dos limites da comarca à uma simples e reduzida clientela urbana local.

Do ponto de vista numérico os destaques são para os serví ços de reparação (mecânica, eletrônica, madeira, etc.), bares e restaurantes, profissionais liberais, salōes de beleza e barbea rias, atividades educacionais e politico-administrativas que re presentam pouco mais de 688 dos estabelecimentos existentes na cidade, como demonstra o quadro abaixo:

\section{A T I V I D A D E S}

Quadro 6

ESTABELECIMENTOS

ABSOL.

Serviços de reparação (oficina mecânica, consertos de calçados, rádios, móveis, oficina auto-elétrica)..................

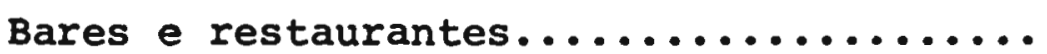

Advogados, médicos, dentistas, engenhei-

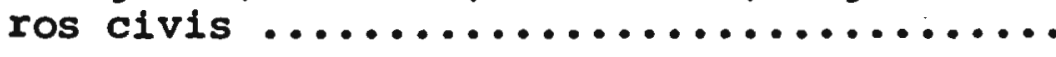

SAlões de beleza e barbearias ...........

Unidades Escolares ( do pré-primārio ao

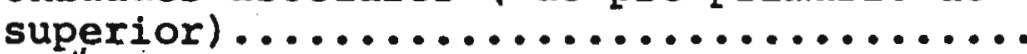

Unidades politico-administrativas (muni-

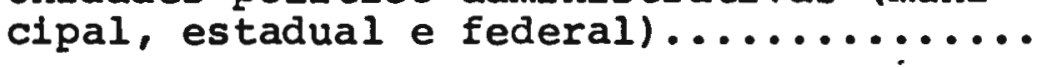

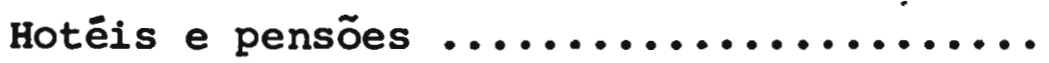

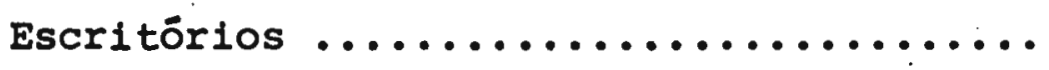

Construtores e projetistas construtores..

BAncos e Caixa Econômica Estadual.........

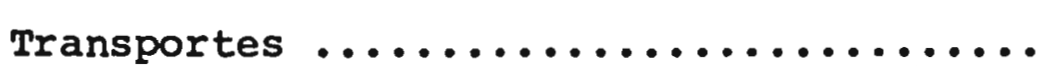

Tinturarias

Outros (publicidade, corretor, agente de seguro, protético, fotógrafos, cinema, -

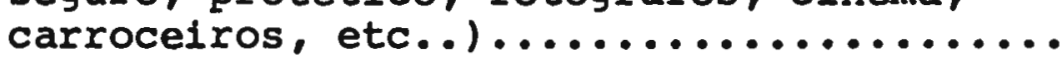
T 0 t a 1

$\begin{array}{rr}48 & 23,19 \\ 40 & 19,32 \\ 24 & 11,59 \\ 12 & 5,80 \\ 12 & 5,80 \\ 11 & 5,32 \\ 6 & 2,90 \\ 6 & 2,90 \\ 6 & 2,90 \\ 5 & 2,41 \\ 4 & 1,93 \\ 4 & 1,93 \\ & \\ 29 & 14,00 \\ 207 & 100,00\end{array}$

-Fonte: Livro de registro das indús trias e profissõas - Prefei tura Municipal de Paraguaçu Paulista - 1974.- 
Analisaremos aquelas funções que mais se destacam não só com a presença urbana, mas, também, de influência regional embo ra restrita.

\subsubsection{A Função Bancária}

Existem em Paraguaçu Paulista cinco estabelecimentos f1 nanceiros: Banco do Brasil, Banco do Estado de São Paulo, Banco Brasileiro de Descontos, Banco Itaú e Caixa Econômica Estadual. Lembramos que o Bradesco e o Itaū, anteriormente constituŕam a gências dos Bancos do Comércio e Industria de Santa Catarina e Banco Comercial do Estado de são Paulo.

Analisando-se o movimento bancário em 1972, exceção fei ta à Caixa Econômica Estadual por não estar incluída na fonte consultada (19), verifica-se que do total conjunto depositado, das agências paraguaçuenses, 948 são provenientes dé particula res, não tendo sido possível definílos quanto à sua origem ur bana ou rural. Entretanto, analisando-se mês a mês observa-se que os meses correspondentes a safras, tanto no seu início quan to no final, apresentam aumento razoável dos valores em depósi to, o que caracteriza de certa forma a presença de zona rural neste aspecto, mecanismo que será melhor esclarecido adiante.

Quanto aos empréstimos, do total aplicado no referido ano, 78,18 destinaram-se à produção, 8,78 ao comércio e 13,08 a ativí dades não especificadas, constituindo na realidade empréstimos particulares ou pessoais. (Tabela 14).

Entretanto as aplicações à produção define-se na sua grande maioria à agropecuária, fato que pode ser verificado pe la observação mais atenta do movimento mês a mês ou pelos dados mais detalhados do último trimestre de 1973.

Procurando correlacionar estes empréstimos à agropecuá ria com depósitos, verifica-se que um aumento no primeiro cor responde a um aumento no segundo e vice-versa quando o movimen to recrudesce. Quanto aos depósitos, uma vez efetuado o finan ciamento, não há aplicação imediata de todo o montante, permane cendo parcela que figura como depósito do público.

(19) - Movimento Bancário - Divisão de Estatística Econômicas Secretaria de Economia e Planejamento úo Estado de São Paulo, 1972 e último trimestre de 1973. 
MOVIMENTO BANCARIO - PARAGUACÇO PAULISTA - 1972

Estabelecimentos com Informaçōes - 4

(Valores em Cr\$)

\begin{tabular}{|c|c|c|c|c|c|c|c|}
\hline \multirow[b]{2}{*}{1972} & \multicolumn{2}{|c|}{ (Valores em Cr $\$$ ) } & I $T \circ S$ & \multicolumn{4}{|c|}{ EMP RESTIMOS } \\
\hline & $C A I X A$ & do público & $\begin{array}{c}\text { de entidades } \\
\text { públicas }\end{array}$ & à produção & ao comércio & $\begin{array}{l}\text { à atividades } \\
\text { não especif.. }\end{array}$ & $\begin{array}{c}\text { à enticades } \\
\text { püblicas. }\end{array}$ \\
\hline $\begin{array}{l}\text { janeiro } \\
\text { fevere1ro } \\
\text { março } \\
\text { abril } \\
\text { maio } \\
\text { junho } \\
\text { julho: } \\
\text { agosto } \\
\text { setembro } \\
\text { outubro } \\
\text { novembro } \\
\text { dezembro }\end{array}$ & $\begin{array}{l}327.799 \\
418.409 \\
369.232 \\
468.621 \\
475.966 \\
494.828 \\
440.031 \\
593.009 \\
431: 098 \\
643.173 \\
539.407 \\
224.462\end{array}$ & $\begin{array}{l}6.315 .863 \\
6.787 .341 \\
6.754 .285 \\
8.000 .805 \\
8.785 .013 \\
5.743 .727 \\
7.609 .693 \\
5.372 .934 \\
5.227 .860 \\
9.725 .599 \\
9.685 .973 \\
6.366 .351\end{array}$ & $\begin{array}{l}456.769 \\
489.900 \\
601.948 \\
511.54: \\
637.197 \\
402.640 \\
503.758 \\
249.104 \\
232.557 \\
396.894 \\
504.081 \\
232.131\end{array}$ & $\begin{array}{r}21.326 .773 \\
21.154 .091 \\
22.708 .392 \\
24.463 .459 \\
26.209 .586 \\
6.537 .584 \\
27.539 .045 \\
2.930 .133 \\
6.150 .500 \\
29.884 .344 \\
33.058 .835 \\
6.548 .395 \\
\end{array}$ & $\begin{array}{l}1.484 .622 \\
1.373 .028 \\
1.593 .111 \\
1.508 .935 \\
3.035 .144 \\
2.376 .813 \\
3.376 .330 \\
1.204 .230 \\
3.280 .419 \\
1.669 .418 \\
2.142 .123 \\
1.579 .630\end{array}$ & $\begin{array}{l}2.972 .807 \\
3.063 .992 \\
3.006 .813 \\
3.036 .555 \\
3.035 .111 \\
3.420 .490 \\
3.308 .895 \\
3.348 .761 \\
1.259 .197 \\
4.205 .326 \\
4.177 .482 \\
3.230 .535\end{array}$ & $\begin{array}{r}220.000 \\
160.000 \\
230.000 \\
200.000 \\
70.000 \\
40.000 \\
10.000 \\
- \\
-\end{array}$ \\
\hline TOTAL & 5.426 .035 & $\begin{array}{r}86.375 .444 \\
94,38\end{array}$ & $\begin{array}{r}5.218 .513 \\
5.78 \\
\end{array}$ & $\begin{array}{r}228.511 .407 \\
78,18\end{array}$ & $\begin{array}{r}25: 367.803 \\
8,78\end{array}$ & $\begin{array}{r}38.065 .965 \\
13,08\end{array}$ & $\begin{array}{r}630.000 \\
0.28\end{array}$ \\
\hline
\end{tabular}

\begin{tabular}{|c|c|c|c|c|c|c|c|}
\hline \multirow[b]{2}{*}{1973} & \multicolumn{2}{|c|}{ DEPOSITOS } & \multicolumn{5}{|c|}{ EMPRESTIMOS } \\
\hline & do público & $\begin{array}{l}\text { de entidades } \\
\text { püblicas }\end{array}$ & AGROPECUARIA & $\frac{P R O D U C A}{\text { INUUSTRIA }}$ & COOPERAIIVAS & Comércio & $\begin{array}{l}\text { atividades } \\
\text { náo especif. }\end{array}$ \\
\hline $\begin{array}{l}\text { outubro } \\
\text { novembro } \\
\text { dezembro }\end{array}$ & $\begin{array}{l}21.628 .199 \\
18.199 .744 \\
16.257 .069\end{array}$ & $\begin{array}{r}738.033 \\
487.138 \\
319.968\end{array}$ & $\begin{array}{l}40.204 .250 \\
43.704 .591 \\
47.468 .352\end{array}$ & $\begin{array}{l}2.165 .619 \\
1.072 .486 \\
1.046 .088\end{array}$ & $\begin{array}{l}1.156 .964 \\
1.162 .602 \\
1.244 .754\end{array}$ & $\begin{array}{l}1.631 .881 \\
1.784 .915 \\
1.891 .594\end{array}$ & $\begin{array}{l}3.921 .935 \\
5.295 .839 \\
5.337 .605\end{array}$ \\
\hline TOTAL & & & $\begin{array}{r}131.877 .193 \\
82,53\end{array}$ & 4.285 .093 & 3.564 .320 & $\begin{array}{r}5.308 .390 \\
5,38\end{array}$ & $\begin{array}{r}14.555 .379 \\
5.18\end{array}$ \\
\hline
\end{tabular}

FONTE: Movimento Bancärio - Divisão de Es tatIstica Economica - SEPLAM - 1972 e ültimo semestre de 73. 
Os empréstimos ao comércio apresentam certa vinculação ao movimento de safra e de certa forma, aos empréstimos à produção. o maior volume de empréstimos ao comércio ocorre nos finais e início das safras e, ao que tudo indica, ligado à renovação de estoques ou à venda de produtos que o comércio oferece através de financiamentos.

Os empréstimos a atividades não especificadas mantêm volume mais ou menos constante durante 0 ano.

Portanto, destas anālises infere-se que a função bancāria de Paraguaçu Paulista volta-se substancialmente para a zona ru ral definindo um pequeno equipamento, onde o maior pêso e atua ção se fazem sentir pelas agências de bancos oficiais de crédito, um dos quais tem jurisdição de âmbito da comarca e com considerá vels aplicações, embora não tenha sido possível medi-las,pode-se dizer que esta constitui uma das funções que amplia a zona de in fluência do centro urbano pela atração que exerce sôbre as popú lações vizinhas.

\subsubsection{A Funcão Educacional}

No campo educacional, a cidade contava, no final de 1974 , com 12 estabelecimentos de ensino: três de pré-primārio (dois man tidos pela prefeitura Municipal e um particular); dois grupos es colares oficiais, com cursos de pré-primário e primeiro grau da primeira à quarta série; Escola do SESI com curso de primeiro grau; dois ginásios estaduais com cursos de primeiro grau da $5 \underline{a}$ à 8 â série; três colégios, sendo um deles com curso de pré-primá rio, primeiro grau e segundo grau com áreas profissionalizantes, en artes industriais e formação de professores primários; um co légio técnico agrícola estadual com curso de monitor agrícola (18 Grau) e Técnico Agrícola (28 Grau); um colégio tēcnico comer cial (particular) com curso de técnico de comércio (28 Grau) é, completando o quadro, a Escola Superior de Agronomia. Neste con junto verifica-se, portanto, a predominância do ensino oficial es tadual e em segundo plano o ensino particular; onde a Fundação Gammon de Ensino, pioneira na atividade na cidade, mantém a Es cola Superior de Agronomia e o Colégio Técnico Comercial.

A função cujas origens remontam a 1921, quando funciona a primelra classe de ensino primário, desenvolve-se durante o pe ríodo de 1940 a 1960 , com a instalação dos grupos escolares, gí. násio pertencente à rede oficial e o ginásio e colégio comercial frutos da iniciativa particular, fatos jā vistos anteriormente. 
Este quadro permanece até o final da década de 1960, tendo-se a crescentado apenas as escolas de pré-primário e cursos tais co mo o "clássico" e o "científico" no estabelecimento oficial. A função que se desenvolvera, exercendo razoavel influência na $A \underline{I}$ ta Sorocabana e Sul do Estado de Mato Grosso, encerra a década com atuação quase que exclusivamente voltada ao centro urbano de Paraguaçu Paulista.

Após 1970, com a criação e instalação de mais três unida des da rede - dois ginásios e o colégio técnico agrícola - ao lado das condições oferecidas pela prefeitura para transporte de alunos da zona rural e a criação, instalação e funcionamento da Escola Superior de Agronomia, a função volta-se ao atendimen to extra-urbano, não se limitando aos municípios prōximos, mas alcançando o Norte do Paranā, sul de Mato Grosso e grande núme ro de cidades paulistas, principalmente na Alta Sorocabana e Al ta Paulista.

Em 1974, tomando-se as três escolas expressivas da ciảa de - Colégio Estadual e Escola Normal "Diva Figueiredo da Silvei ra", Colégio Técnico Agrícola "Antonio Tortorelo Araujo" e Esco la Superior de Agronomia de Paraguaçu Paulista - verificou-se que a primeira, embora com cursos voltados principalmente ao centro urbano, possuia $8,5 \%$ dos alunos de primeiro e segundo graus provenientes da zona rural municipal. 0 colégio Técnico Agrícola "Antonio Tortolero Araujo", inversamente, apresentava uma clientela com apenas 58 provenientes da cidade, 158 da zona rural municipal e 808 dos estados vizinhos: Paranā $(50 \%)$ e Mato Grosso ( 308 ).

A presença desta clientela extramunicipal e extra-regio nal no Colégio Técnico Agrícola, explica-se principalmente pela Insuficiência deste tipo de ensino naqueles Estados e pela pro ximidade de Paraguaçu Paulista às áreas de malor proveniência Norte e Noroeste do Paranā e Sul de Mato Grosso. Deve-se lem brar que estes fatos se repetem para outros colégios agrícolas da Alta Sorocabana. (20)

(20) Kunzli, Ruth "Colégio Técnico Agrícola de Presidente Prú dente como fator de mudança de uma ärea rural" - Trabalho de Mestrado em andamento - F.F.L.C.H. da USP. Tabulação rea lizada para os alunos do 39 ano do C.T.A. de Pres.Prudente apresentou, em 1975, a seguinte proveniência espacial:Esta do de São Paulo 66\%; Paraná 21\%; Região Centro Oeste 11\%; e Estado do Rio de Janeiro $2 \%$. 


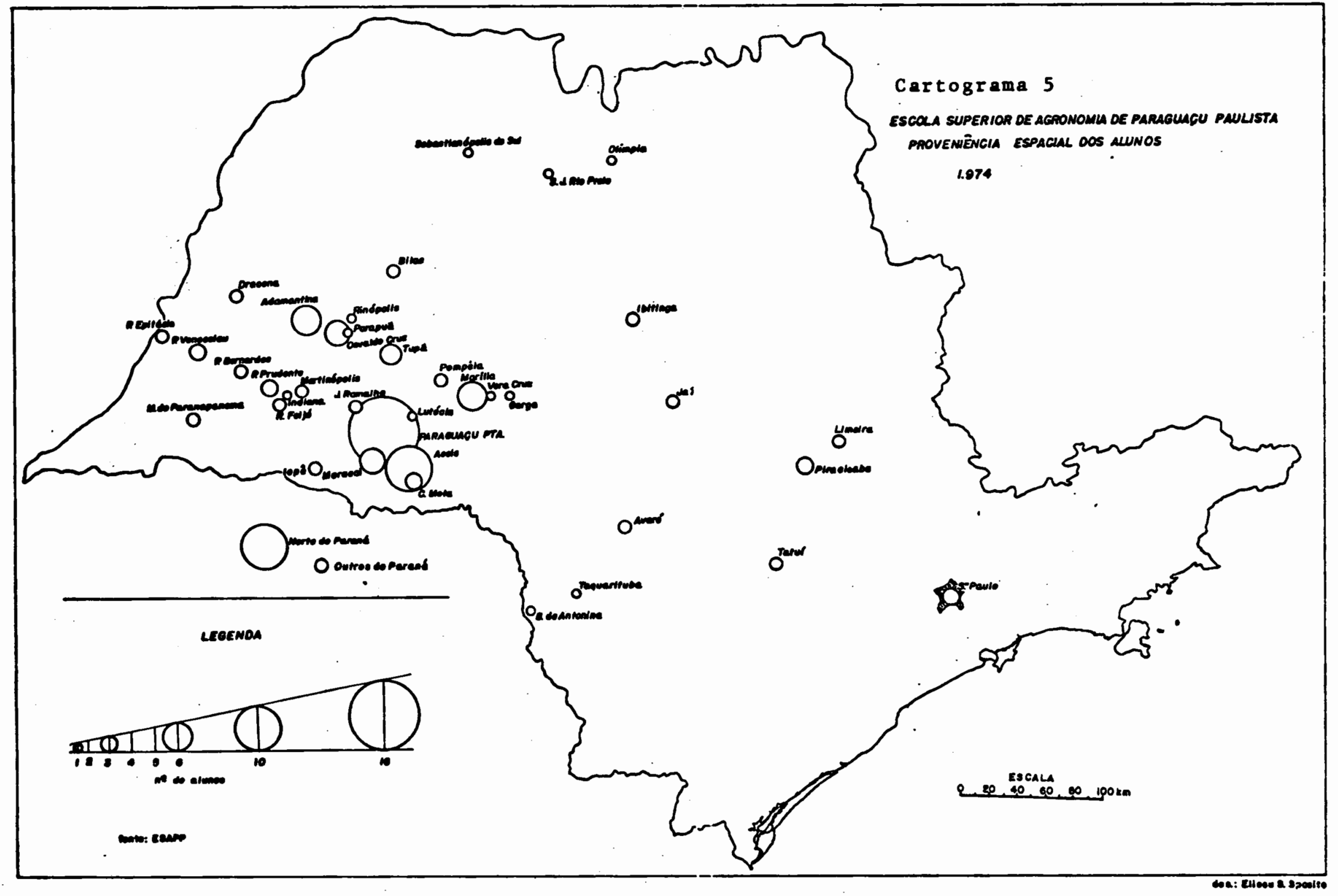


Quanto à Escola Superior de Agronomia, dos 120 alunos fre qüentando o estabelecimento em 1974 (primeiro ano de funcionamen to), 13,338 eram provenientes do município paraguaçuense (apenas dois alunos $(1,668)$ eram provenientes da zona rural); 33,338 da Média e Alta Sorocabana (de Candido Mota a Presidente Epitácio , com maiores destaques para Assis e Maracaí); 25,848 da Alta Pau lista (com maior presença para Marília e Adamantina); 17,5\% das demais regiões do Estado de São Paulo e 108 do Estado do Paraná $(8,338$ do Norte do Estado). (Cartograma 5 )

A presença da escola e desta clientela explica-se pelo fá to de que a maior parte das escolas superiores deste espaço do oeste paulista encontram-se nas capitais regionais ou sub-regionais, com cursos que na sua maioria se sobrepoem e com mercado de trabalho em saturação, excetuando-se a presença de escola de medicina existente em Marília. Procurando explorar estes aspec tos, as iniciativas particular e administrativa locais defini ram-se pela agronomia, opção que se ajustava ao desenvolvimento rural em processo na área e como uma oportunidade profissional de melhores perspectivas em relação àquelas oferecidas pela estrutú ra educacional da região e apenas existente em quatro outros cen tros paulistas, sendo a mais próxima, no oeste do Estado Bandei rante, instalada em Botucatu.

\subsubsection{A Função Médico-Hospitalar}

o equipamento médico-hospitalar de Paraguaçu Paulista con ta com o Hospital de Caridade, Centro de Saúde (Unidade Poliva lente) seis médicos e sete dentistas. (1974).

o Hospital de Caridade é um hospital geral cujo funciona mento é dividido em maternidade, clínica médico-cirúrgica e am bulatório. A maternidade conta com 22 leitos e berçārio com 22 berços e duas incubadoras. No setor de clínica médico-cirúrgica, há 114 leitos (20 para pediatria), dos quais 38 são lucrativos , raios $x$, equipamento de ortopedia, centro cirúrgico e farmácia.

o ambulatório constitui o setor do hospital para atendimentos rá pidos, curativos e pequenas cirurgias.

o Centro de Saúde, Unidade Polivalente, tem funcionamento dividido em clinica geral - atendimento de consultas, exames mē dicos exigidos pelos diferentes órgãos para habilitação profis sional -, pré-natal, pediatria, serviço de puericultura voltado à orientação alimentar, profilaxia do latente, e serviço de pro fllaxia e prevenção cuja atividade principal constitui a vacina 
ção.

o corpo médico é constituido por cinco médicos de clínica geral e um pediatra. Os dentistas não apresentam especialização, dos quais apenas dois possuem serviço de raios $x$.

Considerando-se apenas o município, verifica-se que a re lação leito/habitante apresenta-se dentro dos padrões desejáveis estabelecidos - 4 a 5 leitos gerais por 1.000 habitantes -, para um atendimento no limite mínimo exigido ou procurado, tendo-se em conta que a maternidade retira 22 leitos do total do hospital , restando apenas 92 para uma população aproximada de 23.000 habi tantes.

Com relação aos médicos e dentistas, estes padrões estão muit to aquém do desejắvel, considerando-se que a média ideal defí nida e aceita é a de um (1) médico e um (1) dentista por 1.000 habitantes. (Organização Mundial da Saūde).

Entretanto, estes aspectos agravam-se mais ainda pela de manda por parte dos municípios vizinhos, o que amplia consideravelmente a população a ser atendida, sobrecarregando bastante o setor médico-hospitalar.

Em 1973, O hospital apresentou um total de 4.512. pacien tes internados. Deste total, 81,568 procederam do município sen do 66,098 da zona urbana e 15,478 da zona rural; os restantes $18,44 \%$ procederam quase que na sua totalidade da Alta Sorocabana essencialmente dos municípios vizinhos, como pode ser visto pelo quadro que segue:

THOVENIENCIA ESPACIAL DOS PACIENTES INTERNADOS NO HOSPITAL DE CARIDADE DE PARAGUAÇU PAULISTA - 1973.-

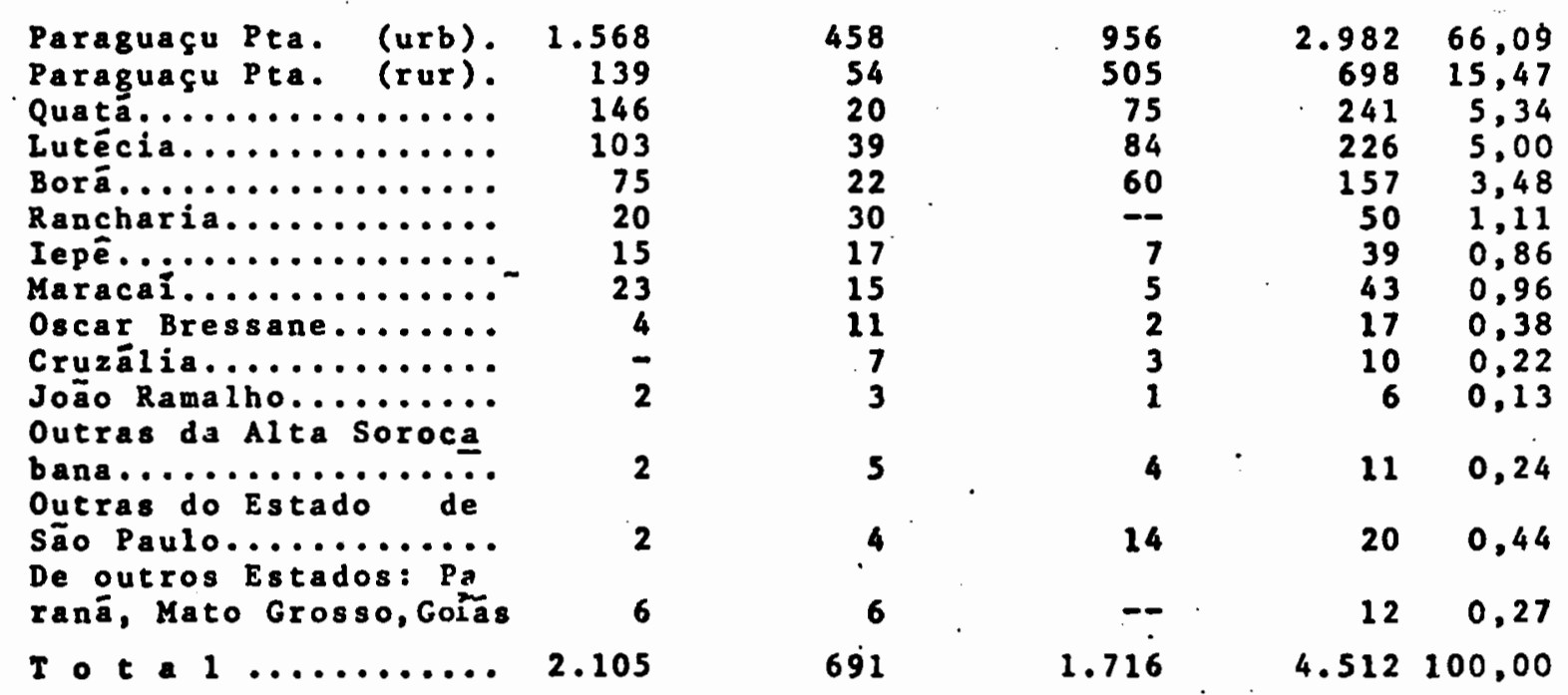

Fonte: Hospital de Caridadede Paraguaçu Paulista. Re lacório do ano de $197 \frac{3}{3}$. 
Por outro lado, deve-se ter em conta que pelo fato do cor po médico não apresentar maiores especializações, parcela da po pulação desloca-se para outros centros de maior importância no setor, tais como Assis, Presidente Prudente, Marília, principalmente para os casos de otorrinolaringologia, oftalmologia, pedia tria, neurologia e psiquiatria. Os casos que necessitam maiores cuidados e especialização são encaminhados para são Paulo, capi tal, havendo atualmente tendência em procurar-se Marília, pela presença de Escola de Medicina naquela cidade.

Quanto ao atendimento dentário, este volta-se essencial mente à cidade, havendo através da Secretaria da Promoção Social unidade móvel que atende à zona rural. Neste setor, embora haja gabinetes dentários nos grupos escolares, o funcionamento dos mesmos está restrito ao Grupo Escolar "Coronel Antonio Nogueira" e ao Curso Primário anexo ao Colégio e Escola Normal Estadual"Dí va Figueiredo da Silveira"; pela falta de dentistas, por ques tões administrativas ao nível do Estado.

\subsubsection{A Função Político-Administrativa}

Esta função configura-se em faragliaçu faulistá, através dos poderes executivo e legislativo municipal; pader judiciário com sede de Comarca abrangendo os municípios do Borá, Lutécia , Oscar Bressane, Maracaí, Cruzália e Paraguaçu Paulista; agência postal rádio-telegráfica da Empresa Brasileira de Correios e Te légrafos que atua coletando e expedindo correspondência e impres sos dos municípios de Oscar Bressane, Lutécia e Borá, sendo este último subordinado diretamente à Paraguaçu, uma vez que aí exis te apenas o Posto do Correio, enquanto que nos dois outros há a presença de Agência do Correio; $18^{\mathfrak{a}}$ Delegacia do Serviço Mili tár que coordena e supervisiona as Juntas Militares de Paraguaçu Paulista, Rancharia, João Ramalho, Quatá, Borá , Lutécia, oscar Bressane e Iepê, constituindo-se ao mesmo tempo, no escalão in termediārio entre estas e a $6^{\text {a }}$ Circunscrição do serviço Militar do Estado de são Paulo, com sede em Bauru. Efetua serviços de se leção, orientação, divulgação e expedição de documentos afetos à atividade militar neste espaço sob sua jurisdição. Entretanto , quanto à prestação do serviço Militar, este restringe-se ao muni cípio de Paraguaçu Paulista pelo fato de que apenas existe 0 Ti ro de Guerra; Agência de coleta de dados do I.B.G.E., com jurís dição sobre Borá, Lutécia e oscar Bressane. (Cartograma 6 ) 
Alèm destes serviços, complementando as atividades do ter ciário de comércio e do secundário paraguaçuense, voltados ao a tendimento ou vinculados diretamente ao setor primário, há o Pos to de sementes. Embora já o tenhamos visto rapidamente na evolu ção das funções, o retomaremos face à sua ārea de atuação contem porânea e à importância que apresenta no movimento econômico do município. .

Com jurisdição bastante ampla (29 municípios) que pode ser melhor depreendida pelo cartograma 3 , tem como objetivo princi pal a preparação e distribuição de sementes. A fase inicial, dos serviços desta atividade do quadro da Secretaria da Agricultura, do Estado de São Paulo, constitui o Plano de Produção de semen tes, que é organizado a partir de levantamento elaborado com um ano de antecedência, através de consulta das intenções de plan tio dos agricultores em cada município da área em questão. Uma vez definidos estes fatos, hã a programação de produção, fase em que são selecionados agricultores nos diversos municípios que através de contratos (campos de cooperação) fornecem as sementes ao posto. Estas são certificadas quanto ao indice de germinação, preparadas para a venda que é feita pelos postos de vendas em cada Casa da Agricultura existentes neste espaço, que as recebem em consignação. Além desta função, cabe ao Posto de Sementes, a través de uma equipe de agrônomos, toda orientação técnica desde o momento da preparação à venda da sementè, bem como a certifica ção daquelas produzidas e comercializadas por particulares na ārea sob sua jurisdição.

No ano de 1974, O Pósto de Sementes de Paraguaçu Paulista realizou um total de vendas de Cr\$22.894.315,00, ○ que signifi cou 14,38 em relação ao valor das vendas da indústria e 19,478 em relação ao valor das vendas do comércio.

Completando o quadro da função polftico-administrativa , há todo o equipamento administrativo estadual de presença apenas municipal: Segurança Pública, Cartórios, Orgãos Fazendários e outros.

\subsubsection{A Função dos Transportes}

Neste setor de serviços, o destaque advém pela presença de transportadora de cargas, de médio porte, equipamento que ra maioria das vezes é encontrado apenas em cidades ao nível de ca pital regional ou sub-regional.

A empresa pertence a uma organização com diversas ativí 


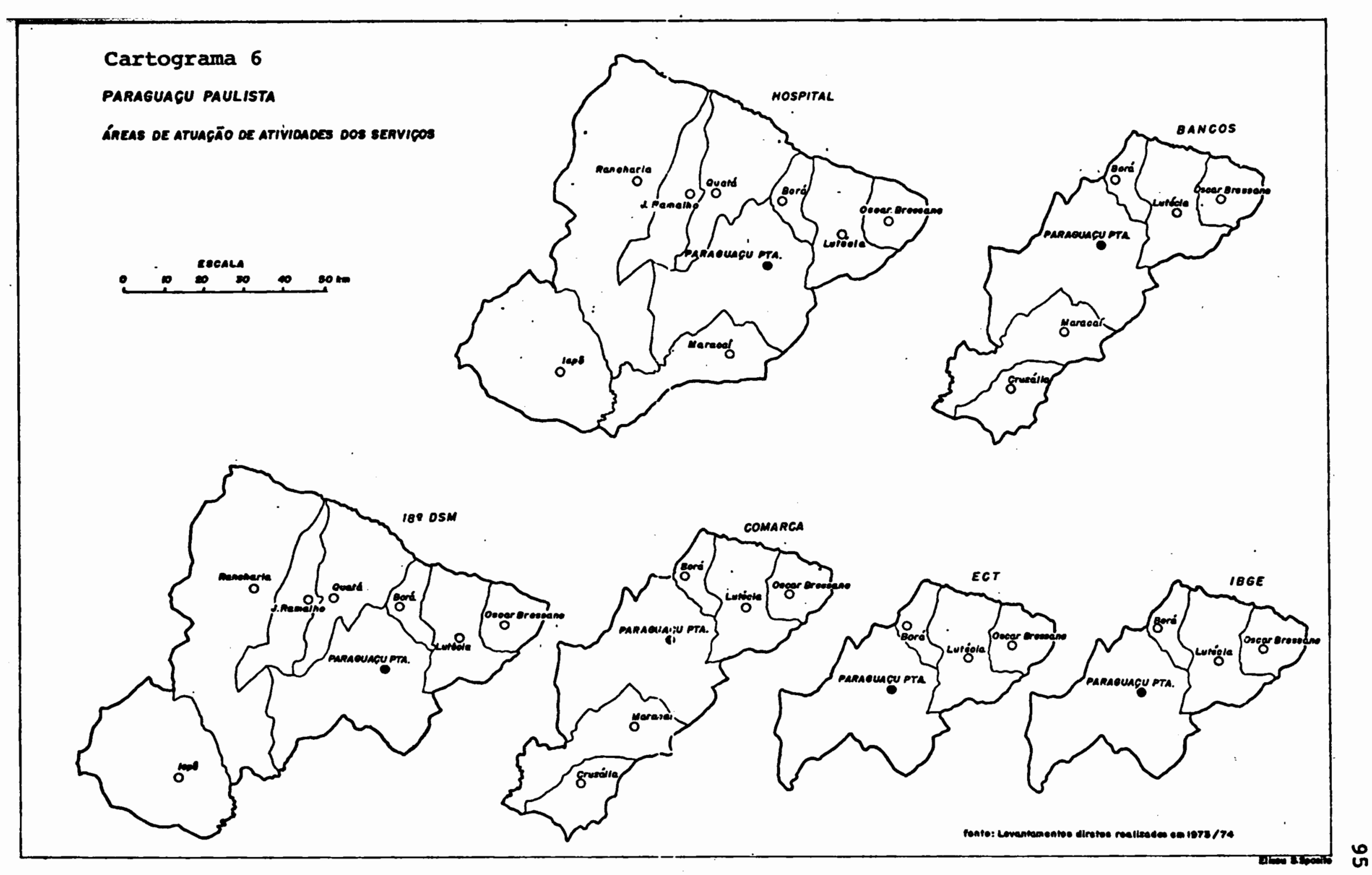




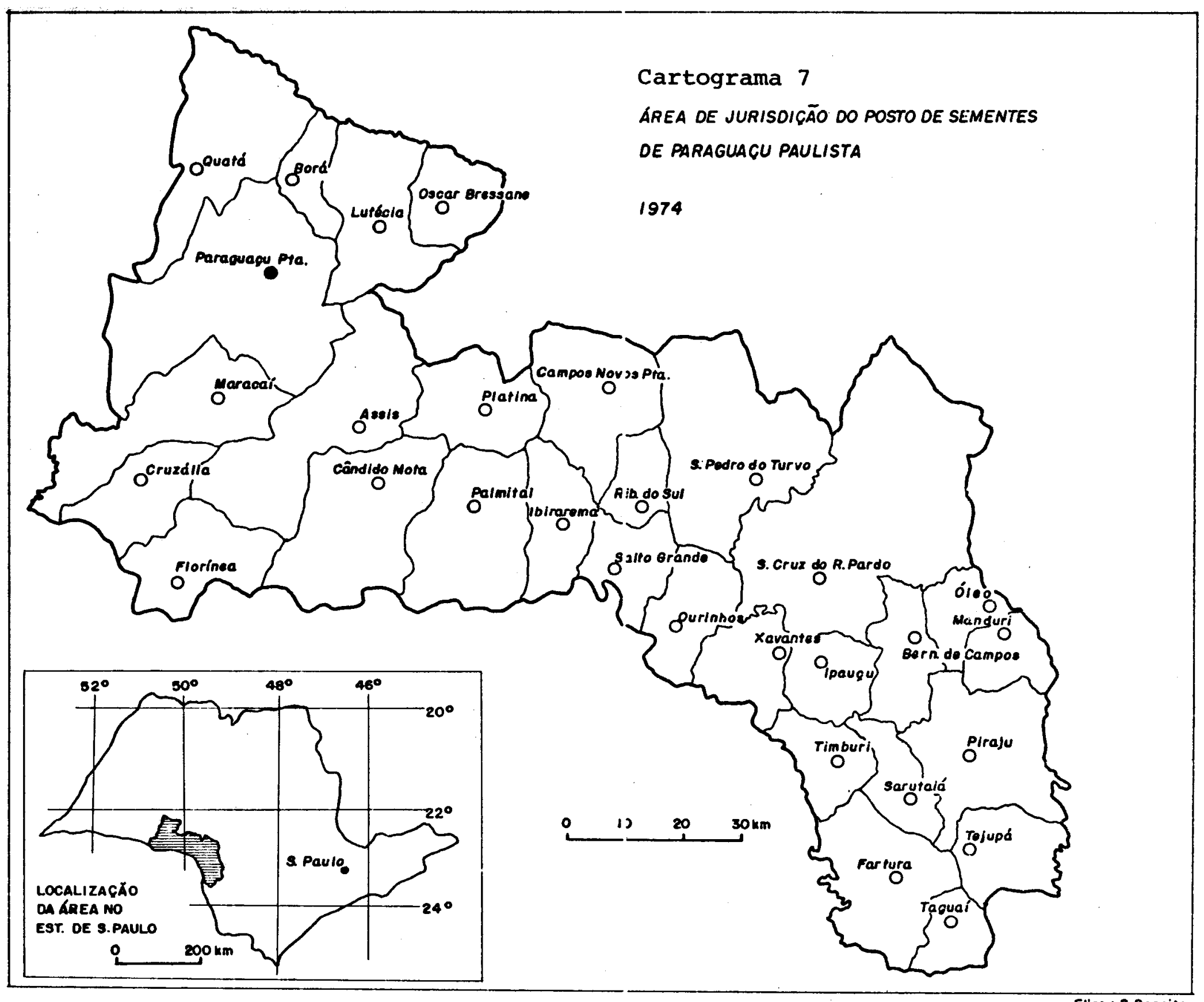


dades: propriedades rurais voltadas à criação de bovinos ou a agricultura, benefício de arroz e café, comércio de cereais e posto de gasolina. A sua origem resulta de um prolongamento das primeiras atividades da organização: aquisição de dois ou três caminhōes para o transporte ou de cereais por ela comercializa dos ou de cereais matéria-prima para sua indústria de beneficia mento. Nos dois casos o transporte aparece em três momentos: co leta, destinação para o beneficiamento ou estocagem e distribui ção da matéria-prima ou produto para o consumo.

Definida em 1971, jā em 1974 a transportadora contava com 30 caminhões de média tonelagem (em média 15 toneladas) executan do apenas o transporte de carga séca orientado para e a partir da capital paulista como frete de retorno.

Para São Paulo as cargas procedem em $60 \%$ da Alta Soroca bana: 458 de Paraguaçu Paulista (faralo de soja a granel e ou tros produtos agrícolas beneficiados ou não), 108 de Rancharia e Quatá (algodão beneficiado, farelo de soja, fios de algodão), e $5 \%$ dos demais municípios existentes entre Assis e Presidente Epitácio, com os : mais variados tipos de cargas. Os restantes 408 das cargas são fornecidos pelo Norte do Estádo do Paranã : Londrina (algodão beneficiado e farelo de soja), Apucarana e Ma ringá (algodão beneficiado e cereais, principalmente milho e feijão) .

A partir da metrópole paulista para o interior há um mo vimento de $80 \%$ das cargas transportadas, enquanto que os demais 208 são fornecidos essencialmente pelas cidades localizadas na Depressão Periférica Paulista. Deste movimento de transporte em direção ao Oeste, $50 \%$ das cargas destinam-se à Média e Alta So rocabana, de Piraju a Presidente Epitácio: 308 representados pe las farinhas do Moinho Santista, $7 \%$ pelos adubos - estes distrí buidos entre Palmital e as áreas de Iepê e Paraguaçu Paulista-, 68 pelo calcáreo proveniente de Piracicaba, Itapeva, Itapetinin ga, destinados principalmente a Paraguaçu Paulista e municípios vizinhos; 78 pelo cimento que é descarregado em Presidente Pru dente (3\%), Paraguaçu Paulista (2\%), Presidente Venceslau e Pre sidente Epitácio (28). A segunda metade das cargas destina-se ao Norte do Estado do Paraná e ao Sul do Estado de Mato Grosso: 308 representados pelas farinhas do Moinho Santista distribuí das de Cornélio Procópio a Umuarama, 108 pelos adubos remetidos para a área entre Cambé e Campo Mourão. Para Mato Grosso - 108 das cargas - segue o calcáreo que é entregue em Campo Grande e áreas próximas em um raio de 200 a $250 \mathrm{~km}$. 
Entretanto, os transportes em escala inter-regional são realizados: entre a Alta Sorocabana, Norte do Paraná e sul de Mato Grosso. Nestes casos transporta-se produtos rurais - trigo soja, arroz, café - destinados ao benefício próprio, à fábrica de óleos vegetais existentes na cidade e aos depósitos da CEAGESP. 


\subsubsection{A Função de Residència de Proprietários e Assalariados Rurais}

Jă se verificou anteriormente que Paraguaçu Paulista cons titui um centro de coleta, beneficiamento e comercialização de produtos rurais e distribuidor de gêneros e serviços. A estas fun ções acrescenta-se a de residência de proprletários e assalaria dos rurais, função esta que resultará no carreamento para o cen tro urbano de considerável parcela da renda fundiária gerada pe las atividades rurais, face à fixação na cidade do homem cujas atividades constituem aquelas vinculadas diretamente, em parte ou totalmente, .ao setor primärio.

\subsubsection{Os proprietártos rurais}

Atravēs dos levantamentos realizados por Teixeira (21) , verificou-se que o municíplo possula 928. propriedades que soma vam 101.767,9 Ha (Recadastramento do INCRA - 1972), com as se guịntes caracteristicas fundiārias: 705 entre 0 e menos de 100 Hectares abrangendo 25.136,6 Ha; 196 entre 100 e menos de $500 \mathrm{Ha}$ abrangendo $26.256,1 \mathrm{Ha} e$ apenas 29 acima de $500 \mathrm{Ha}$ com o total de $24.449,8 \mathrm{Ha}$. (Tabela 13)

Das 928 propriedades cadastradas, 541 delas $(58,298)$ pos suíam proprietários absenteístas. Este absenteísmo caracteriza -se principalmente pela residência em Paraguaçu Paulista de pro prietários de 327 delas $(60,44 \%)$. Em outros municípios paulistas residem os detentores de 100 outras $(18,488)$ : Assis, 36; São Paulo 16; Quatá 10 e Maracä́ 8, são as de maior presença (22). As 114 restantes $(21,088$ tèm declarações indicando absenteísmo de seus proprietários, nãö nos sendo possível definir os locals de residências, pela falta de informaçōes mals concretas.

Das 327 propriedades rurais pertencentes aos residentes na ciq̧ade paraguaçuense, há forte presença daquelas consideradas pequenas - menos de $100 \mathrm{Ha}$-, que somam 68,60z, seguida das mé

(21) - Teixeira, Márcio Antonio - "Organização do Espaço Rural no Município de Paraguaçu Paulista". Trabalho de Mestrado em andamento, F.F.L.C.H. da Universidade de São Paulo.

(22) - Alēm destas figuram: Cruzāila 5, Presidente Prudente 3, Ourinhos 3, Tupa 2, João Ramalho 2, Rancharia 2, Regente Faijó, Capivari, Bastos, Botucatu, Piracicaba, 0svaldo Cruz com 1 cada e Cambará (PR) com 4 . 
dias - 100 a menos de $500 \mathrm{Ha}$-, com 26,308, restando às grandes - mais de $500 \mathrm{Ha} \mathrm{-,} \mathrm{a} \mathrm{participação} \mathrm{de} \mathrm{apenas} \mathrm{4,908} \mathrm{naquele} \mathrm{to}$ tal(23). Em relação ao total de propriedades do município (928) esta característica e ordem permanecem. Entretanto, quando se considera classes de propriedades, verifica-se uma ordem inver sa de participação, ou seja, as pequenas propriedades dos absen teístas paraguaçuenses são em menor número, cabendo às grandes a maior participação. (Tabela 15)

Em termos de dominação fundiāria, verifica-se a marcante presença da cidade na zona rural do município. Através das 327 propriedades $(35,248$ das 928$)$, nota-se um controle de $41.508,5 \mathrm{Ha}$ - que significa 40,798 da ārea total das propriedades rurais do município. Desta considerável área rural sob dominação urbana , as pequenas propriedades detêm 18,148, as médias $42,658 \mathrm{e}$ as grandes 39,128 , tendência que se mantém quando consideradas as classes de propriedades e a área total das propriedades no muni cipio. (Tabela -15)

Constituem, do ponto de vista das atividades rurais, pro priedades com forte orientação para a pecuária: dos 41.508,5 Ha, 72,758 são dedicados às pastagens, com 17.157 cabeças de gado bovino, significando 45,158 das pastagens e 45,278 do rebanhomu nicipal. A distribuição de domínio das pastagens é semelhante ao da dominação fundiária: as pequenas propriedades somam 17,358 da área com pastos, as médias 38,678 e as grandes $43,98 \%$, ordem que permanece, embora com menores Indices, quando vịta em relação à ăreas de pastagens das classes de propriedades e área total de pastagens do municipio. Entretanto, quanto ao rebanho bovino de tido pela cidade, tem-se forte presença das médias propriedades que são possuidoras de 50,398 deste, seguidas das grandes ( com $28,808)$ e pequenas $(20,398)$, fatos que se repetem de forma se melhante tanto em relação ao rebanho de cada classe no município, quanto ao total. (Tabela 15)

Considerando-se proprietários e propriedades, verifica-se que hã uma concentração fundiāria. As 327 propriedades são deti das por 243 proprietários, acentuando a presença de médios e grandes. Da área total dominada pela cidade, os pequenos proprie tários somam 158 detendo 13,858 do espaço, os médios são em nū mero de 70 com 31,708 e os grandes apenas 15, mas controlando ' 54,458 daquela área.

Ainda dentro desta linha de análises, hã que se conside

(23) - As consideraçôes de pequena, média e grande propriedade, obedecerá. critério apenas de área e segundo o consenso local, podendo este, entretanto, variar para pouco mais ou pouco menos dos limites por nós estabelecidos. 
Propriedades rurals com proprietārios absenteistas residentes em Paraguaçu paulista Area total area das pastagens e rebanho bovino

\begin{tabular}{|c|c|c|c|c|c|c|c|c|c|c|c|c|c|c|c|c|c|c|c|c|}
\hline & \multirow{2}{*}{\multicolumn{4}{|c|}{ MUNICIPIO }} & \multicolumn{16}{|c|}{ PROPRIEDADES C JM PROPRIETKRIOS RESIDENTES NA CIDADE DE PARAGUAÇU PAULISTA } \\
\hline & & & & & \multicolumn{4}{|c|}{ PROPRIEDNDES } & \multicolumn{4}{|c|}{ AFE: DAS PROPRIEDADES } & \multicolumn{4}{|c|}{ AREA DAS PASTAGENS } & \multicolumn{4}{|c|}{ REDAMIIO BOVI:O } \\
\hline $\begin{array}{l}\text { CLASSES } \\
\text { (em HA) }\end{array}$ & $\begin{array}{l}\text { nírero } \\
\text { de fzo } \\
\text { prieda } \\
\text { des.- }\end{array}$ & $\begin{array}{l}\text { irea to } \\
\text { tal das } \\
\text { proprie } \\
\text { dades }\end{array}$ & $\begin{array}{l}\text { irea to } \\
\text { tal das } \\
\text { pasta- } \\
\text { gens.- }\end{array}$ & $\begin{array}{l}\text { Rebanho } \\
\text { Bovino }\end{array}$ & $\begin{array}{l}\text { No de pro } \\
\text { priedades } \\
\text { doml nada } \\
\text { pela cida } \\
\text { je.- }\end{array}$ & $\begin{array}{l}\text { lobore o } \\
\text { tot.nl da } \\
\text { classe do } \\
\text { municiplo }\end{array}$ & 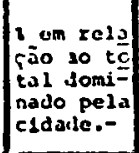 & $\begin{array}{l}\text { lem rela } \\
\text { caio do to } \\
\text { tal do mu } \\
\text { niciplo. }\end{array}$ & $\begin{array}{l}\text { Xrea doms } \\
\text { noda pel } \\
\text { cldade. : }\end{array}$ & $\begin{array}{l}\text { sôbre o } \\
\text { otal da- } \\
\text { rea da } \\
\text { lasse na } \\
\text { unlctplo }\end{array}$ & $\begin{array}{l}\text { soobre o } \\
\text { total da } \\
\text { arca domi } \\
\text { nada pela } \\
\text { cldada.- }\end{array}$ & $\begin{array}{l}\text { ice ircla } \\
\text { cuo a irej } \\
\text { total do } \\
\text { munleíplo }\end{array}$ & $\begin{array}{l}\text { irea de } \\
\text { jastagens } \\
\text { comanida } \\
\text { pela cida } \\
\text { do.- }\end{array}$ & 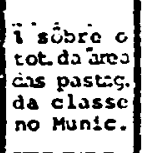 & 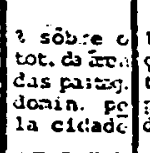 & 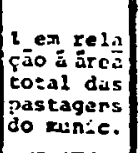 & $\begin{array}{l}\text { Rebarsio } \\
\text { bevi:o de } \\
\text { il rado fú } \\
\text { la cldade } \\
\text {. }\end{array}$ & 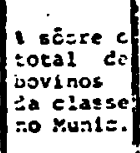 & 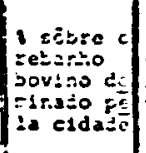 & 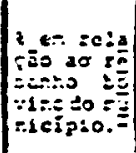 \\
\hline$\bullet-\dot{\sim} 100$ & 705 & $25.136,6$ & $16.176,8$ & 11.601 & 225 & 31,91 & 68,80 & 24,25 & $7.529,4$ & 29,95 & 18,14 & 7,40 & $5.238,8$ & 32,38 & 17.35 & 7,83 & 3.493 & 30,15 & 20,39 & 9,23 \\
\hline$: 00 \rightarrow 500$ & 194 & $39,233,3$ & $26.256,1$ & 17.475 & 86 & 44,33 & 26,30 & 9.27 & $17.703,4$ & 45,12 & 42,65 & 17,40 & $11.676,7$ & 44,47 & 38,67 & 17,46 & 8.718 & 49,39 & 50,82 & 23,00 \\
\hline - or soo & 29 & $37.398,0$ & $24.449,8$ & 8.821 & 16 & 55,17 & 4,20 & 1,72 & $16.275, i$ & 43,52 & 39,21 & 15,99 & $23.281,2$ & 54,32 & 43,98 & 19,86 & 4.941 & 56,01 & $23, \varepsilon 0$ & 13,04 \\
\hline $20: 12$ & 928 & 102.767 .9 & $06.832,7$ & 37.897 & 327 & 32,24 & $100, \infty$ & 32,24 & $41.508,5$ & 40,79 & $100, \infty$ & 40,79 & 30.296 .7 & 45,15 & $200, \infty 0$ & 45,25 & 17.157 & $45,2 ?$ & $100, \infty$ & 45,27 \\
\hline
\end{tabular}

Fonte: Mărcio Antonio Telxeira - "Organizaçäo do Espaço Rural no Municiplo de Paraguacu Paulista" (Inédito)
Recadastramento do INCRA - 2972 . 
rar a presença do proprietário rural na cidade segundo sua or gem, sendo esta de duas ordens: proprietários rurais que trans ferem sua residência para a cidade ou citadinos com atividades urbanas que adquirem propriedades rurais e permanecem com a at 1 vidade urbana.

Os proprietārios de origem rural residentes na cidade são mais numerosos e detentores de mậros áreas tanto no conjunto das pequenas propriedades quanto das médias, cabendo aos propr 1 etārios de origem: urbana maior dominação fundiária através das grandes propriedades, embora sejam inferiores quanto ao número em relação aos de origem rural como demonstra a Tabela 16 .

\begin{tabular}{|c|c|c|c|c|c|c|c|c|c|c|c|c|}
\hline \multirow[b]{3}{*}{$\begin{array}{l}\text { Classes de } \\
\text { propriedades }\end{array}$} & \multirow{2}{*}{\multicolumn{2}{|c|}{$\frac{\text { Origem }}{\text { rbana }}$}} & dos & \multicolumn{3}{|c|}{ proprietarios } & \multirow{2}{*}{\multicolumn{2}{|c|}{$\begin{array}{c}A r e \\
\text { urbana }\end{array}$}} & \multirow{2}{*}{\multicolumn{2}{|c|}{$\begin{array}{c}\text { dom } i n a d a \\
\text { rural } \\
\end{array}$}} & & \\
\hline & & & \multicolumn{2}{|c|}{ rural } & \multicolumn{2}{|c|}{ total } & & & & & tor & 1 \\
\hline & $\mathrm{Abs}$ & $\begin{array}{l}7 \text { sōbre } \\
0 \text { total }\end{array}$ & ibs. & $\begin{array}{l}7 \text { sôbre } \\
0 \text { total }\end{array}$ & $2 \mathrm{bs}$. & $\begin{array}{l}\text { sobre } \\
\text { tot-geral }\end{array}$ & $\begin{array}{c}\text { absoluta } \\
\text { (Ha) }\end{array}$ & $\begin{array}{l}x \text { sōbre } \\
\text { otoral }\end{array}$ & $\begin{array}{c}\text { absoluta } \\
(\mathrm{Ha})\end{array}$ & $\begin{array}{ll}7 & \text { sóbre } \\
0 & \text { total }\end{array}$ & $\begin{array}{c}\text { absoluta } \\
\text { (Ha) }\end{array}$ & $\left\{\begin{array}{l}\text { \%ôbre } \\
\text { tot.geral }\end{array}\right.$ \\
\hline$\dot{0}=100 \mathrm{Ha}$ & 36 & 22,78 & 122 & 77,22 & 158 & 65,02 & $1.627,1$ & 28.31 & $4.120,9$ & 71,69 & $5.748,0$ & 13,85 \\
\hline 101 \& $500 \mathrm{Ha}$ & 25 & 35,71 & 45 & 64,29 & 70 & 28,81 & $4.691,0$ & 35,65 & $8.466,7$ & 64,35 & $13.157,7$ & 31,70 \\
\hline + de $500 \mathrm{Ha}$ & 6 & 40,0 & 9 & 60,00 & 15 & 6,17 & $16.090,5$ & 71,19 & $6.512,3$ & 28,31 & $22.602,8$ & 54,45 \\
\hline Total Geral & 67 & 27.57 & 176 & 72,43 & 243 & 100,00 & $22.408,6$ & 53,98 & $19,099,9$ & 46,02 & $41.508,5$ & 100,00 \\
\hline
\end{tabular}

Fonte: Teixeire, Marcio Antonio - "Geografia - Agrária do Municipio de Paraguaçu Pau

Com relação aos proprietários de origem urbana, verifí cou-se que estes são na sua grande maioria comerciantes, dominan do tanto propriedades quanto área: representam 52,238 dos 67 proprietários e dominam 78,348 dos $22.408,8 \mathrm{Ha}$.' O setor de ser viços apresenta 26,878 destes proprietários controlando 11,878 da área, sendo que destes $11,90 \%$ são profissionals liberais (mé dicos, dentistas, advogados e engenheiros) cuja ārea total de suas propriedades representam 5,958. Aqueles ligados às ativida des industrials - 11,908 - , dominam 9,78z da ārea nas mãos de proprietários de origem citadina e somam 20,908 destes.

Além destes fatos, analisou-se o comportamento das 100 propriedades pertencentes àqueles que residem em outras cidades paulistas e paranaenses. Estas dominan 29.877,9 Ha do município, representando 29,368 de sua ărea rural. As maiores dominações provêm de Assis $(9,628)$, são Paulo $(7,918)$, Ourinhos $(1.618)$ e Quatá $(1,23 \%)$. Por outro lado, Paraguaçu Paulista controla 64 propriedades em outros municípios paulistas, somando a área to tal destas 8.459,2 Ha. Estes municípios localizam-se essencial mente na Alta Sorocabana. As maiores dominações paraguaçuenses estão no municíplo de Quatá $(2.767,1$ Ha ou 4,978 da área rural deste município), Iepê $(1.990,2 \mathrm{Ha}$ ou 2,65 da sua área rurall e 
Maracal $(1,551,2$ Ha ou 3,168 da área rural municipal)

A presença do homem rural residindo no centro urbano pa raguaçuense data dos primeiros anos de existência do núcleo, on de a figura do fazendeiro de café, do criador de suínos, em al guns casos, confundia-se com a do beneficiador e comerciante, as pectos que permencem até o final da década de 1940. \$ partir deste período começa a acentuar-se o processo de transferência do rural para a cidade, na medida em que se assinala o desenvol vimento das pastagens ao lado do retraimento das culturas algo doeira e cafeeira.

A atividade pecuăria que tivera sua expansão intciada nos meados da décadaanterior, desenvolve-se - por ser uma atividade pouco exigente em solos e mão-de-obra - com lucros elevados e seguros e atendendo os estímulos de um mercado consumidor que se ampliava e diversificava atravēs do desenvolvimento da urbaniza ção. Reforçando estes fatos, as atividades algodoeira e cafee ra apresentavam exigências opostas às da pecuária quanto aos so los e mão-de-obra, ao lado de resultados econômicos que oscilavam entre anos de bons lucros e outros de grandes prejuizos.

Estes aspectos tem como consequiência a diminuição da po pulação rural, o desenvolvimento relativamente rápido das pasta gens e rebanhos bovinos das médias e grandes propriedades. Esta evolução resultou no fortalccimento c concentração de capiläis nas mãos de seus proprietārios e o enfraquecimento das pequenas propriedades, gerado pelas crises das lavouras que alladas ao pequeno espaço que possuiam, constituiram entraves à adaptação destas à atıvidade pecuāria.

Na medida em que médios e grandes proprietārios definem as áreas de suas propriedades, caracterizando um processode con centração fundiāria, seja pela compra de pequenas e mesmo de mé dias: propriedades, seja por heranças, aspectos que se acentuam durante a década de 60 , parte destes transferem-se para a cida de. Esta transferência è mals comum entre médios proprietários, uma vez que parte representativa das grandes propriedades estão vinculadas aos capitais e investimentos de origem urbana.

A fixação do proprietário na cidade verifica-se no momen to emique as propriedades estejam organizadas, são de fácil ad ministração (geralmente complementada por capataz ou parente) e

(24)- As informaçoes aqui utilizadas foram extraídas do traba lho "Relaçoes entre a estrutura fundiária e a rede urbana na Alta Sorocabana"- Maria Massae Hangai e Walter Pfanemul ler-FAPESP e F.F.C.L. de Presidente Prudente - 1971.-

Além dos municípios citados, Paraguaçu Paulista exerce presença nos seguintes (serão apresentades as áreas e per centagens que estas representam da área rural destes muni cípios): Rancharia - 1.286,1 He ou 0,987; João Ramalho $554,1 \mathrm{Ha}$ ou 2,177; Cruzália - 209,8 Ha ou 0,84\% e Martinó polis - $100,7 \mathrm{Ha}$ ou $0,117 .-$ 
por estarem fortemente orientadas para a pecuária. Ao lado dis to outros estímulos surgem, impelindo o homem rural a fixar-se na cidade: facilidades de movimentos e relações entre a proprie dade e a cidade, criadas pela presença de melhor rede viária; a perspectiva de melhores condições tanto para a comercialização, quanto para a efetivação de suas produções, pois é na cidadeque mantém os contatos, toma conhecimento dos preços, realiza negó cios, faz o abastecimento da propriedade, obtém empréstimos; ma Ior conforto; melhor educação dos filhos; e, finalmente, a obten ção do " status" residencial urbano, refletido no investimento que faz na construção de sua residência citadina e no padrão de vida que passa a apresentar, o que, na maior parte dos casos, re vela sua estabilidade e condição econômica.

o pequeno proprietārio ainda efetua algumas tentativas na lavoura antes de transferir-se para a cldade. Entretanto, a par tir dos sucessivos reveses que sofre neste tipo de atividade, de cide-se a fixar-se no centro urbano, passando a viver neste do aluguel de pastos, arrendamento das terras que faz tanto a mé dios quanto a pequenos proprietárlos melhor sucedidos; do aumen to de seu pequeno rebanho bovino do qual obtém algum rendimento através da venda do le1te, do desfrute (venda dos machos) e re posição do rebanho (permanece com ạ fềmeas nascidas, vendendo as vacas mais velhas); dos rendimentos de pequenas lavouras per manentes (café) ou temporárias das quais consome parte (arroz, milho). Há ainda casos daqueles que vendem parcela de sua pe quena propriedade, ou umaidelas quando possul mais de-una, apli cando o capital apurado na aquisição de dois ou três imóveis ux banos, ocupando um deles e usufruindo do aluguel dos demais, ou aplicam èste capital com renda fixa. o seu padrão de vida nãose rá melhor que aquele que possuía na zona rural. Os seus rendinen tos tornam-se mals certos, mas os seus gastos são maiores, bas tando levar em conta que fica privado de gêneros alimentícios que produzia para auto-consumo e que agora tem necessidade de obtê-los na cidade. 0 aspecto mais posit1vo desta transferência, constitui-se na oportunidade de melhor educação dos filhos e as perspectivas de que estes venham a obter uma "profissão urbana".

Em paralelo a todos estes fatos, a população rural trans ferindo parte considerável de suas rendas para a cidade, trans ferêncla esta configurada no consumo de gêneros, serviços, efe tuando transações comerciais e utllizando, para suas produções, - equipamento de coleta, beneficiamento e comercialização exis tentes na cidade, gera lucros e proporciona o acúmulo de cap tais nas mãos de comerciantes, industriais ou de pessoas vincula das ao secundário (gerentes, funcionários mais graduados) ou ' terciário de serviços (bancários, médicos e outros liberals ) , 
que terminam por aplicar tais rendas na aquisição de terras, nas quais a maior parte do espaço será dedicado às pastagens.

A aplicação deste excedente da renda comercial, dos ser viços, da indústria, na aquisição de propriedades rurais ocorre em função de vārios fatôres. Inicialmente muitas destas proprie dades foram adquiridas no momento em que as terras apresentavam um baixo valor e em que se verificava o forte das saídas da zona rural (final dos anos 50 e durante a década de 60), frutos das crises das lavouras e implantação da pecuária, o que irá refle tir, também, no centro urbano, afetando as mais diferentes atividades da cidade. Estes fatos implicam na preocupação destes homens urbanos de que não haveria, pelo retraimento que se verí fica nos diferentes setores de atividades citadinos, compensa ção de aplicações na mesma atividade que estavam exercendo. Con seqüencia disto, a propriedade rural constitui àqueles de maior iniciativa, uma diversificação de atividades, cuja produção pos suía mercado garantido e em expansão. Ào mesmo tempo representa uma capitalização de seus excedentes econômicos que the garantí rá a obtenção de crédito e dinheiro a balxo custo, que em parte utilizará nos negócios urbanos, sem que haja detrimento da at vidade rural.

Em vārios casos, esta aplicação de capital que inicialmen te apresenta-se apenas como uma diversificação de suas atıvida des, torna-se, ou pela valorização das terras ou crescimento e expansão econômica da propriedade, o ramo principal dos negōcios destes citadinos. Em outros a aquisição da terra constitui a ca pitalização de suas poupanças (mais comum entre industriários , bancārios , professôres), capitalização esta esperada quase sem pre pela valorização das terras, havendo, eventualmente, alguma renda à partir delas.

Finalmente, a obtenção do "status" de fazendeiro que the darā projeção e melhores relações tanto na realızação dos seus negócios, ou mesmo socialmente.

Com relação à renda fundiária que a cidade obtém à par tir do domínio fundiário que exerce no município, tomou-se como exemplo um conjunto amostra de 65 propriedades. Os dados sobre estas foram obtidos atravēs do cadastro do INCRA - 1972 e mode 10 "A" da Declaração de Dados Informativos Necessārios à Apura ção dos Indices de Participação dos Municípios Paulistas no Pro duto da Arrecadação do ICM - 19̣74, no caso, referentes a Para 
guaçu Paulista.

Estas propriedades detidas por 29 proprietärios, abrangem uma área de $16.339,5 \mathrm{Ha}$, com valor de vendas declarado, para aqueles ano, de Cr $\$ 6.324 .156,00$. Nestes resultados obtidos, veri fica-se uma vez mals o predomínio das médias e grandes proprie dađes e a concentração tanto numérica quanto de área nas mãos de poucos proprietārios, o que ocorre principalmente na classe acıma de $500 \mathrm{Ha}$, ao lado de concentração da renda fundiária, fá to também observado naquelas entre 100 e $500 \mathrm{Ha}$, o que pode ser melhor apreendido no quadro abaixo.

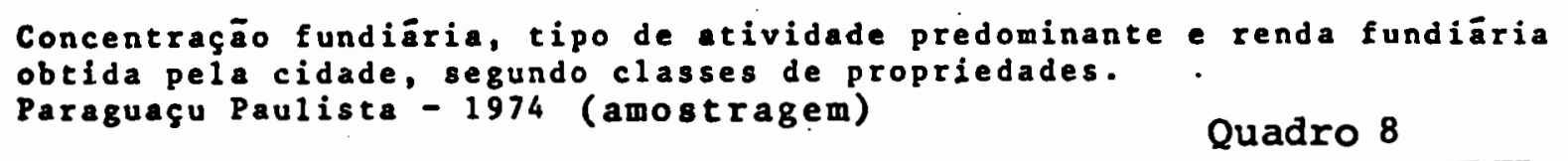

\begin{tabular}{|c|c|c|c|c|c|c|c|}
\hline $\begin{array}{l}\text { Classe de } \\
\text { proprieda } \\
\text { des, em } \\
\text { Ha. }\end{array}$ & $\begin{array}{l}\text { ng de } \\
\text { propri } \\
\text { E tärios }\end{array}$ & $\mid \begin{array}{l}\text { No de } \\
\text { prop ri } \\
\text { edade }\end{array}$ & $\begin{array}{l}\text { Area to- } \\
\text { tal das } \\
\text { proprie- } \\
\text { dades }\end{array}$ & $\begin{array}{l}\text { Area to- } \\
\text { tal das } \\
\text { pastagens } \\
\text { das prop. }\end{array}$ & $\begin{array}{l}\text { Total de } \\
\text { bovinos } \\
\text { das pro } \\
\text { priedad }\end{array}$ & $\begin{array}{l}\text { Area co } \\
\text { tal da } \\
\text { agricul } \\
\text { tura }\end{array}$ & $\begin{array}{l}\text { Valores totais } \\
\text { das vendas de } \\
\text { claradas. }\end{array}$ \\
\hline 0.100 & 14 & 16 & 673,6 & $5 i 4,9$ & 603 & 69,9 & $1.511 .169,00$ \\
\hline $101: 500$ & 9 & 16 & $2.235,5$ & $1.652,7$ & 1.359 & 402,4 & $2.324 .757,00$ \\
\hline t de 500 & 6 & 33 & $13.430,4$ & $9.830,5$ & 5.608 & 499,0 & $2.488 .230,00$ \\
\hline Total & 29 & 65 & $16.339,5$ & $11.998,1$ & 7.570 & 971,3 & $6.324 .156,00$ \\
\hline
\end{tabular}

Fonte: Cadastro do Incra 1972 rodélo "A" para cálcu los de indices do ICM $-1974 .-$

Procurando considerar-se estes dados como válidos para o conjunto dominado pela cidade no município, o que deve-ser visto com cautela, uma vez que não nos fol possível consegui-los para toda a área rural de domínio urbano; que os mesmos expressam da dos globais sem qualquer indicação da distribuição dos valores aplicados nas propriedades e queles que são retidos na cidade ; que constituem dados declarados pelos proprietarios sem qualquer confirmação ou contrôle; e tendo em conta o salário mínimo regio nal da época (1974) (25), inferiu-se que os proprietários rurais absenteístas residentes em Paraguaçu Paulista, teriam obtido ren das fundiárias brutas equivalentes a aproximadamente $\quad 41.625$ salários minimos em um ano, ou perto de 3.470 salários mínimos mensais. (26).

$(25)-\operatorname{Cr} \$ 386,00$

(26)-Esta inferência foi obtida dentro do seguinte raciocínio: se 16.339,5 Ha, que correspondem a $39,36 \%$ da área total dominada pela cidade, apresentaram valores totais de ven das declarados iguais a Cr\$6.324.156,00 (1974), os $100 \%$ de área dominados pela cidade, ou seja, 41.508,5 Ha, apre sentariam renda fundiāria da ordem de Cr\$16.667.470,0 $\overline{0}$, equivalente a 41.625 salários mínimos regional. Para as demais dominaçoes foi utilizado o mesmo raciocínio. 
Dentro desta linha de análises, considerou-se ainda a pre sença de Paraguaçu Paulista coletando rendas em outros municí pios, já citados, através da dominação fundiāria que sobre eles exerce, bem como a zona rural paraguaçuense fornecendo rendas pela dominação que the è exercida de fora. No primeiro caso, do minando 8.459,2 $\mathrm{Ha}$, obteria rendas fundiárias de aproximadamente $\operatorname{Cr} \$ 3.280 .000,00$, o que significaria perto de 8.500 salários minimos anuais ou aproximadamente 700 salários minimos mensais. Entretanto, no segundo caso, os fatos tornam-se marcantes: so frendo uma dominação externa em 29.877,9 Ha forneceria renda fun diária de aproximadamente $\operatorname{Cr} \$ 11.500 .000,00$, o que daria perto de 30.000 salários mínimos anuais ou 2.500 salários mínimos por mês.

\subsubsection{O Assalariado Rural}

Segundo levantamentos realizados em Paraguaçu Paulista, fins de 1971 e Início de 1972 (Tabela 29), das 1.576 pessoas e conomicamente ativas vinculadas aos diferents setores de atividades, 276 encontravam-se ativas no setor prinário. Destas, de ambns os sexns: 182. derlaravam-se trahalharinres volantes, repro sentando 6,078 dos potencialmente ativos e 11,908 dos economica mente ativos do centro urbano.

Em levantamentos realizados por uma equipe de voluntạ rios da Paróquia Nossa Senhora da Paz e Prefeitura Municipal de Paraguaçu Paulista, com tabulações realizadas pelo Consōrcio In termunicipal da Promoção Social sediada na mesma, em fins de 1971 na Barra Funda, um dos setores onde se verifica presença / acentuada de população com nível de vida inferior em relação ao conjunto urbano, foram entrevistadas 600 familias abtangendo 3.469 pessoas, das quais 2.397 acima de 14 anos. Dos chefes de familias entrevistados, 570 déclararam o exercício de uma profi.s. são, sendo 226 volantes, o que significava $9,43 \%$ daqueles poten clalmente ativos neste setor da cidade.

Considerando-se como representativas estas amostragens , observa-se a existência relativamente marcante de assalariados rurais residindo na cidade, constituindo estes aproximadamente 48 da população urbana (13.331 pessoas segundo o Censo de 1970), principalmente na periferia, onde a Barra Funda e Vila Nova são os setores de maior presença destes.

o fenômeno registra-se a partir dos fins da década de 
1940, Intensificando-se nas décadas seguintes face ao recrudes cimento da agricultura, expansão das pastagens, alteraçẳo nas re laçōes patrão-trabalhador rural e Legisiação Trabalhista.

A sucessão dos produtos rurais - cafē, algodão, gado -ín teressando mercado distante, a concentração fundiāria ao final desta sucessão, constituem a manifestação e fortalecimento do sistema capitalista de produção no meio rural paraguaçuense e comum na Alta Sorocabana, com reflexos diretos nas relaçōes pro prietário-trabalhador rural.

Os sistemas utilizados na exploração da força de traba lho se sucedem ou coexistem, na medida em que se processa ocupa ção do espaço rural e se sucedem os produtos. As primeiras le vas de trabalhadores rurais que aportaram no muntcípio foram em pregadas nas empreitas para a abertura das terras, derrubadas de matas, primeiros plantios tanto para auto-consumo ou de comerc1 allzação local, quanto dos cafezais. Aó final dos anos 20 e iniclo da década seguinte, surgem os cáfezais já formados e, ao lado da empreita utilizada para os novos espaços que estavam sen do abertos, procurando garantir a mão-de-obra necessária não a peṇas para a formação do café ou para uma safra, mas por um pe ríodo de vários anos, os proprietārios lançam mão do sistema de colonato. Com o inf́clo da decadência do café e presença do al godão nós meados da década de 30 , o novo produto acelera a ut lização dos sistemas de parceria e arrendamento, que passan a ser bastante comuns na cultura da malvácea, embora já viesse sen do utilizado esporádicamente na cultura cafeeira.

A medida que as pastagens avançam sôbre as āreas de ma tas ou de terras incultas ou substituem os cafezais e algodoais, sempre atendendo o mercado consumidor distante, as relações ca pitalistas manifestam-se mais acentuadamente. A nova atividade' proporciona lucros seguros, acumulação mais rápida do capital que se fará principalmente pela ampliação da propriedade -, e, ao mesmo tempo, por ser menos exigente em mão-de-obra, libera grande massa de trabalhadores rurais que se desloca para outras áreas rurais (Norte do Paraná, Sul de Mato Grosso), para a Gran de São Paulo e pequena parcela instala-se na cldade constituindo a fôrça de trabalho rural excedente que passará a ser utili zada pelos proprietários rurais no sistema diarista. A opção do proprietário por esse sistema de trabalho, constituirá um fator a mais na redução dos custos da produção, uma vez que passa a utilizar-se de mão-de-obra apenas suficiente aos trabalhos e em 
épocas necessárias ( preparo de terras, plantio, colheitas, : re formas de pastagens, cercas, roçadas ) o que o deseobriga degas tos que possuía com arrendatários, parceiros: instalações, 'manu tenção, fornecimentos, garantia de financiamentos, atendimento médico, educacional, etc..

À partir de 1963, com a Legislação Trabalhista - Estatuto do Trabalhador Rural -, o procedimento capitalista é reforça do. As relações patrão-empregado se distanciam, deixando, na maior parte dos casos de ser diretas, passando a ser relações pa trão-turmeiro, gato, fiscal, empreiteiro, livrando-o dos encar gos de contratos por tempo determinado, descanso semanal remune rado, pagamento de horas extras, indenizações, assistência médí ca, e outros mais.

Finalmente o trigo e soja, culturas mecanizáveis, surgem como fatos recentes reafirmando o sistema capitalista: de um la do atraem investimentos nos bens de produção, representados pe la aquisição de máquinas que pouco oneram os custos, pois são na sua quase totalidade financiadas e de auto-pagamento ( reali zando os trabalhos da prop̄riedade ou sendo alugada por outros. / proprietários ); de outro, como consequiência direta destes fa tos, L1beram mão-de-obra, uma vez que estas äreas que agora re cebem estas culturas eram ocupadas por outras atividades rurais e que, mesmo no sistema diarista, utilizavam trabalhadores que se veem substituídos pelas máquinas.

Através de entrevistas realizadas junto a 18 volantes re sidentes em Paraguaçu Paulista ( 27 ), verificou-se que os dife rentes aspectos relativos às condições de trabalho, de vida des ta população rural excedente fixada neste centro urbano, genéri camente reafirmam o $j a ̄$ analisado por outros autores em trabalhos realizados para a Alta Sorocabana (28) ou para o Estado de são Paulo ( 29 ). Contudo, , através das particularidades $\therefore$ pro curar-se-á caracterizar esta população ao nível local..

(27)- Estas entrevistas foram realizadas em fins de 1975. To mou-se como referência para a escolha dos entrevistados, as indicações feitas pelo primeiro volante com o qual man tivemos contato.

(28) - Mello, Maria Conceição D'Incao - "O Boia Fria na Alta So rocabana" - Tese de Doutoramento apresentada a F.F.C. e Le tras. de Presidente Prudente - 1973.-

(29.)-Rossini, Rosa Ester - "Contribuição ao Estudo do Exôdo Rural no Estado de São Pauio"- Tese de Doutoramento apre sentada ao Departamento de Geografia da F. F.l. e Ciências Humanans da Universidade de São Paulo - 1975. 
Entre os entrevistados a idade inicial de trabalho estā compreeendida entre 8 e 14 anos, sendo mais raros nas faixas de 13 e 14 anos (168). As suas idades, no momento da entrevista, va rlavam entre 17 e 54 anos, dos quais 508 possuíam mais de 30 / anos. Os mals idosos ( 30 a 54 anos) acompanharam a sucesøão dos produtos rurais e os sistemas de trabalho (empreita, parce ria, arrendamento, diarista), enquanto que os mais novos ( 17 a 30 anos) já têm suas primeiras atividades vinculadas diretamente ao trabalho diarista. Esta sucessão de relações de trabalho é acompanhada por uma mobilidade espaclal por parte desta popula ção, que se faz essencialmente ao nível do município e áreas pró ximas, figurando como mais distante a presença de alguns deles no Norte do Estado do Paraná, mas com retorno à área. Esta mo bilidade não é característíca apenas dos mais velhos, sendo / grande a movimentação por parte dos jóvens. (30)

Esta população expulsa da zona rural, em função dos fạ tos jā vistos anteriormente, fixa-se na cidade trazendo consigo. a expectativa de que nesta poderá encontrar melhores condiçōes de vida, empregos, habitações, possibilıdade de educar os filhos. Entretanto, ela não conseque integrar-se nas atividadeș urbanas pelo. fato de que a economia urbana nao cresceu em ritmo capaz de absorvê-la, sendo raras as oportunidades que surgem, ou .por que the falta qualificaçōes ou experiências para tanto. Nesta situação resta-lhe tornar-se volante nos.trabalhos sazonários / que a zona rural oferece, passando a viver na cidade em condi ções mais empobrecidas, mésmo miseráveis, bastante inferlores à quelas que possuía no campo.

Em alguns casos, principalmente referentes aos mais jọ vens, a possibilidade de deixar o sistema diarista surge quando se verifica a expansão de algum setor de atividade na cidade sendo a construção civil o mais recente; implantação e conserva ção do equipamento público urbano ( redes de ãguas, esgotos, ca pinação de ruas), ou pela presença de grandes obras do Estado na região ou ārea próxima: construção de hidroelétricas (Hidroelétrica de Capivara), estradas (capeamento asfáltico ligando Para guaçu Paulista a Assis, Quatá, Rancharia, à SP 421 - que conduz a Marília), cujos serviços pouco ou quase nada exigem em termos de qualificação, mas com suficiente necessidade de mão-de-obra ca

( 30 )- Como exemp 10: do grupo dos mais jovens, seis deles des locaram-se, a partix de 1965, pelos municípios de Tupã, $T$ Quata, Candido Mota, Assis, Maracaí, Cruzālia, Paraguaçu Paulista. 
paz de absorvê-los. As oportunidades que surgem são as de ser vente de pedreiro, auxiliar de carpinteiro, trabalhador bra çal. Embora a maioria destes subempregos seja temporária, a ex periência, os "conhecimentos" neles obtidos figuram comocon dições favoráveis para a obtenção de trabalho na cidade ou em outras áreas do Estado ou do País, onde realizam obras semelhan tes.

Como volante, a maior ou menor possibilidade de obter tra balho e de ganhos, prende-se a dois períodos do ano: 1) entre os meses de setembro a abril - considerado periodo da safra - quan do o trabalho surge em função do preparo das terras, plantios , limpeza e conservação de lavouras e pastagens, colheitas; 2) en tre maio e agosto - considerado entre-safra - período em que o trabalho volta-se essencialmente ao corte da cana-de-açúcar pa ra as usinas açucareiras localizadas nos municípios vizinhos ( Usina Santa Lina, no municipio de Quatá, Usina Santá Amélia , no municlpio de Maracaf). O seu recrutamento é diário e o paga mento semanal. Durante a safra, pela maior exigência de mão-de -obra, o preço por dia de trabalho alcançava, em 1975, cr $\$ 25,00$. Na entre-safra, pela abundância de trabalhadores, serviços ofe recidos na forma de tarefas, os recebimentos diārios ficavam en tre $\operatorname{Cr} \$ 15,00$ e $\operatorname{Cr} \$ 20,00$. Assim, considerando-se que estes traba lhadores obtıveram serviços todos os dias úteis (não trabalham' apenas no domingo), os seus salários mensais ficaram, em termos aproximados, naquele ano, acima do salário mínimo regional $(17,5 \%)$ durante a safra e abaixo $(17,8 \%)$, na entre-safra, o que vale di zer, considerando-se a média anual, ao mesmo nível.

Visto apenas nesta perspectiva, a sua condição de vida urbana seria semelhante àquela que possuía como trabalhador per manente no campo. Contudo, deixando esta última situação e pas sando à de trabalhador sazonário de residência urbana, aquela / condição surge com nível sensívelmente mais baixo. Permanente na zona rural, contava com habitação, no geral de condiçōes razoá veis, lenha; alimentação mais farta e rica, obtida das suas pro duçōes e criações para auto-consumo (cereais, leite, ovos, fru tas, aves, etc.), realizadas em pequena parcela que the era ce dida para tal fim na propriedade rural, ou mesmo retirando da produção, destınada à comercialização, o suficiente para sua ma nutençäo durante 0 ano. Alèm destes benefícios em espécie, re cebia uma remuneração a qual destinava-se à complementação da sua manutenção: vestuário, medicamentos, alguns bens de consumo 
durável e outros. Transferindo-se para a cidade como trabalha dor sazonário na zona rural, o seu salário eleva-se aparentemente, 1sto porque as suas necessidades, embora sendo as mesmas . nesta nova condição de vida acarretam maiores dispêndios: gran de parte dos seus vencimentos são gastos na aquisição da alimeñ tação que se torna insuficiente e empobrecida, o que irá refle tir diretamente não só na condição de saūde, mas também naque las da família. (Vide páginas 131 a 133)

As condições habitacionais urbanas tornam-se precārias : arrumam-se na periferia da cidade ocupando habitações de barro te, barracos armados com madeira velha ou de caixotes, cobertas com sapé, folhas de zinco ou semelhante, jā deterioradas pelo tempo ou com telhas velhas recolhidas de restos de demolições , piso de chão batido. Em condições pouco melhores a estes, outros ocupam, como inquilinos e raramente como proprietários, as ve lhas e desgastadas casas de madeira existentes nos limites do centro urbano. 


\section{Capitulo 4:- A POPULAÇฐO URBANA}

4.1. Evolução da População Municipal

4.2. Estrutura da Pọulą̧ão e Pirâmide das Idades

4.3. Mortalidade e Natalidade

4.4. Provenịência Espacial da População Urbana

4.5. Estrutura Profissional da Popula ção Urbana

4.6. Estrutura Econômica da População Urbana 


\section{A POPULAÇÃO URBANA}

\subsection{Evolução da População Municipal}

A partir de 1940 , o município de Paraguaçu Paulista es trutura-se, em termos político -administrativos, em quatro distri tos: Paraguaçu Paulista - distrito sede -, Borá, Conceição de Mon te Alegre è Sapesal. Esta estrutura permanece até 1964, quando o distrito de Borá é desmembrado constituindo-se município. Resta considerar que parcela do municipio de Maracaí- bairros rurais de Roseta e Cardoso de Almeida - é anexada ao de Paraguaçu Paulista, no mesmo ano.Embora Borá constitua municipio, o manteremos em 1970, nas anālises que se seguem.

Considerando-se a população a partir de 1940, ano que se rá tomado como base para cálculos de índices, verifica-se que a população decresce em termos totais, embora permaneça estāvel na década de 1940/50. O decênio de maior perda é 1960/70, quando a população apresenta déficit de 3,8z. (Tabela 17)

Esta evolução da população total é acompanhada, em grau mais acentuado, pela população rural que em 1971 é deficitária em

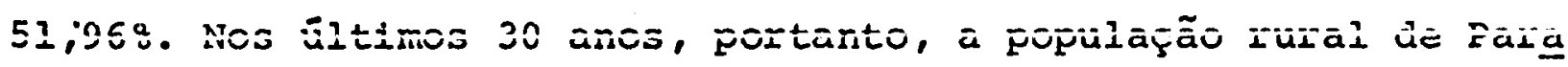
guaçu Paulista reduziu-se em mais da metade. Entretanto, maior de créscimo ocorreu entre 1950/60, quando à população rural perdia 30,168 do:seu efetivo, como pode ser observado pelas tabelas 17 e 18 .

Em termos urbanos a situação se inverte: a população cres ce rapidamente. Tomando-se como base ainda 0 ano de 1940, O índi ce de crescimento urbano em 1970 é de 263,4 e o decênio de maior incremento è 1950/60. (Tabela 18)

Ao nivel dos distritos altera-se consideravelmente esta $\underline{e}$ volução. O distrito da sede apresenta crescimento gradativo no quadro municipal, alcançando no ültimo decênio o índice de 166,9 . Entretanto, os maiores aumentos ocorrem nos dois primeiros: 25,82 \& entre $1940 / 50$ e 20,258 entre 1950/60. Os distritos de Concei ção de Monte Alegre, Sapesal e Borā decrescem, com maior déficit ocorrendo neste ültimo que, em 1970, se apresenta com índice de 27,98 . Em termos absolutos significa diminuição de 3.274 pessoas. Ressalve-se neste conjunto, como exceção, que sapesal na década de 1940/50, conhece um crescimento de 18,78. (Tabelas 17 e 18)

A evolução repete-se quando vista para as populaçōes urba nas: o distrito da sede, isto è, a cidade de paraguaçu paulis ta, è o único que apresenta crescimento, alcançando em 1970 o 
Populaçäo total, urbana e rural

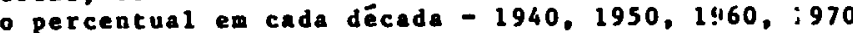
Municipio de Paraguaçu Pauliata

Tabela -17

\begin{tabular}{|c|c|c|c|c|c|c|c|c|c|c|c|c|c|c|c|c|c|c|}
\hline & \multicolumn{6}{|c|}{ IOTAL } & \multicolumn{6}{|c|}{$0 \& A \times A$} & \multicolumn{6}{|c|}{$R \cup R A L$} \\
\hline & \multicolumn{2}{|c|}{$1940 / 50$} & \multicolumn{2}{|c|}{$1950 / 60$} & \multicolumn{2}{|c|}{$1960 / 70$} & \multicolumn{2}{|c|}{$1940 / 50$} & \multicolumn{2}{|c|}{$1950 / 60$} & \multicolumn{2}{|c|}{$1960 / 70$} & \multicolumn{2}{|c|}{$1940 / 50$} & \multicolumn{2}{|c|}{$1950 / 60$} & \multicolumn{2}{|c|}{$1960 / 70$} \\
\hline & Pop. & $z$ & Pop. & $z$ & Pop. & $z$ & Pop. & $z$ & Pup. & $z$ & Pop. & $z$ & Pop. & $z$ & Pop. & $z$ & Pop. & $z$ \\
\hline Distrito de Sede & +2.594 & $+25,82$ & +2.560 & $|+20,25|$ & +1.563 & $|+10,28|$ & +2.122 & $+37.34 \mid$ & +4.829 & $+73,59 \mid$ & +1.940 & $+17,03$ & +474 & $+8,45$ & -2.269 & $-37,33$ & $-\quad 377 \mid$ & $-9,89$ \\
\hline $\begin{array}{l}\text { Conceligäo de Monte } \\
\text { Alegre }\end{array}$ & -1899 & $-27,14$ & $|-1.077|$ & $|-21,13|$ & 584 & $|-14,52|$ & 32 & $\mid+12,1) 8$ & & $|-14,81|$ & & $|-6,32|$ & -1.931 & $-28,68$ & -1.033 & $-2 i, 52 \mid$ & -568 & $-15,53$ \\
\hline Sapesal & +519 & $+18,74$ & -1.245 & $-37,85 \mid$ & 353 & $|-17,27|$ & +358 & 156,33 & $-\quad 200$ & $|-34,07|$ & & $-25,06 \mid$ & +361 & $+15,42$ & -1.045 & $-38,68 \mid$ & -256 & $-12,52$ \\
\hline Borá & -1.029 & -22.65 & $-\begin{array}{cc}- & \cdots \\
- & 703\end{array}$ & $-20,00 \mid$ & -1.542 & $-54,83 \mid$ & 0 & 0,00 & +-58 & 35,58 & $\mid \begin{array}{r}-\cdots \\
-\quad 98\end{array}$ & $-44,34$ & -1.029 & $-23,49$ & $=761$ & $-22,70$ & -1.444 & $-51,35$ \\
\hline Total do Município & +185 & $+0,70$ & 465 & $-1,89$ & 626 & $+2,60$ & +2.512 & $\mid+47.62$ & +4.643 & $|+61,02|$ & $|+1.827|$ & $+14,91$ & -2.125 & $-11,15$ & -5.108 & $-30,16$ & -1.201 & $-10,16$ \\
\hline Municipio + Boré & & & & & 916 & $-3,80$ & & & . & & +1.729 & $+14,11$ & & & & & -2.645 & $-22,37$ \\
\hline
\end{tabular}

Fontes: Censo de 1940, 1950, 1960 e 1970 
População Urbana, Rural e Total em 1940, 1950, 1360 e 1970

Municipio de Paraguaçu Paulista

Indíce de crescimento $-1940=100$

Tabela 18

\begin{tabular}{|c|c|c|c|c|c|c|c|c|c|}
\hline & \multicolumn{3}{|c|}{1950} & \multicolumn{3}{|c|}{1960} & \multicolumn{3}{|c|}{1970} \\
\hline & Urbana & Rural & Total & Urbana & Rurai & Total & Urbasa & Rural & Totál \\
\hline Distrito da sede & 147,8 & 108,4 & 125,8 & 256,5 & 68,0 & 151,3 & 300,2 & $6 I, 2$ & 156,9 \\
\hline Conceição de Monte Alegre & 112,0 & 71,3 & 72,8 & 95,4 & 56,0 & 60,0 & 89.4 & 47,5 & 49.1 \\
\hline Sapezal & 136,8 & 115,4 & 118,7 & 90,2 & 60,8 & 73,8 & 67,5 & 59,8 & $6 \pm, 0$ \\
\hline Borà & 100,0 & 76,5 & 77,3 & 135,6 & 59,1 & 61,8 & 75,5 & 26,2 & 27,9 \\
\hline Total do Municíplo & 143,6 & 88,9 & 100,7 & 231,3 & 62,0 & 98,8 & 261,6 & 42,1 & 39.9 \\
\hline Muntcipio + Borá & & & & & & & 263,4 & 48,2 & 95.1 \\
\hline
\end{tabular}

Fonte: Censos de 1940, 1950, 1960, 1970. 
Indice de 300,2. Deste valor, período a periodo, a cidade al cançou maior crescimento na década de 1950. Os distritos, embo ra com pequenas populações urbanas, decrescem e tornam-se defí citários a partir de 1950, exceto Borá, que estável entre:: 1940 e 1950, tem ligeiro crescimento na década seguinte: 35,588 . (Ta belas 17 e 18)

A população rural, contrariamente à urbana, decresce pau latinamente em todos os distritos, sendo mais acentuado em con ceição de Monte Alegre e Borā, que trazem em 1970 indice de 47,5 e 26,2, respectivamente. O períodode maiores perdas da população rural ocorre entre 1950/60, conforme tabela 18.

Retomando os números da população, verifica-se que há rẹ lativa estabilidade para o total municipal, com pequeno aumento na década 1940/50 e decrēscimo, igualmente pequeno, nas seguin tes.

Analisando-se as três décadas após 1940, verifica-se que - crescimento vegetativo mantém-se relativamente constante embo ra decline e mais acentuadamente na última.

o maior crescimento vegetativo ocorre na década de 1940, quando a taxa percentual para os 10 anos alcançou $26,59 \%$, consi detraụa a pupuiaçãu tutai du município no início ào periodo. nés te espaço de tempo o saldo real:, isto é, a diferença entre. a população nas duas datas do Censo, foi de apenas 185 habitan tes representando somente $0,76 \%$, enquanto que a emigração cor respondia a 25,83\%. A década seguinte é mais significativa: o crescimento vegetativo diminui alcançando 25,458 , enquanto que - saldo real é negativo $-1,898$ e a taxa emigratóría chega aos 27,348. O último período traz o menor crescimento vegetativo: 22,298; O saldo real acentua ainda mais o negativo, cuja taxa para o período alcançou $-3,80 \%$ e a taxa emigratória assemelha-se àquela da dēcada de 40:26,108. (Tabela 19)

Entretanto, ao considerar-se esta população aos niveis de rural e urbana, encontra-se situações bastante diferentes.

Na primeira década $(1940 / 50)$, o aumento absoluto ocorri do no total da população, como já se salientou, é de 185 pes soas; a população urbana tem um incremento de 2.312 pessoas en quanto que a rural perde 2.127 pessoas. Ora, considerando-se / que a taxa média de crescimento vegetativo foi de 26,6 por 1.000, deveria ter ocorrido acréscimo de cercá de l. 100 pessoús ná zo na urbana e aproximadamente 5.070 na rural. Face a is to pode-se deduzir que uma parcela considerável da população rural dirige 
-se para a cidade, enquanto que o restante procura outras áreas.

Estes fatos se repetem nos dez anos seguintes $(1950 / 60)$, com intensificação do processo urbano: a taxa média de cresci mento vegetativo é de 25,4 por 1.000, o que corresponderia a um acréscimo de aproximadamente 1.930 pessoas na urbana e 4.300 na rural, sendo que na realidade verificou-se um aumento de $\mathbf{4 . 6 4 3}$ urbanos e perda de 5.108 rurais, valores que representam queda no total de 465 habitantes (Tabelal9 A)

A ūltima dēcada traz a mesma estrutura, alterando-se os números em seus componentes. A taxa de crescimento vegetativo que crescera ligeiramente na anterior, apresenta-se ainda menor: 22,3 por 1.000; a população total acentua a sua diminuição: me nos 735 pessoas. Entretanto, as maiores alterações ocorremem relação aos números da população rural e urbana. A primeira de veria ser acrescida em aproximadamente 2.635 pessoas, mas se vê diminuida em 2.645. Portanto, considerando-se 0 aumento vegetati vo a população rural decreśceu em aproximadamente 5.261 pessoas. Enquanto isto a população urbana que deveria aumentar em cer ca de 2.730 pessoas alcançou apenas 1.724 ( Tabela 19A), notando -se, portanto, que também a cidade de Paraguaçu Paulista entrou em processo de perảa,

Neste último decênio verifica-se, face ao exposto, que a saída da população rural atenua-se ao lado de recrudescimento da população urbana e esta ültima, que nos anos anteriores absorvia grande parcela da primeira, passa a sofrerperdas, ocorrendo, ev 1 dentemente, as menores no núcleo principal.

Examinando-se, embora rapidamente, o desenvolver da estrú tura econômica do municipio, poderemos encontrar as causas des tas alterações, muito sensíveis no comportamento numérico da po pulação de Paraguaçu Paulista.

A estrutura econômica do município nestas três ültimas dê cadas apresenta sensiveis mudanças.

A.s culturas do café e algodão, segundo os dados dos Cen sos, apresentam-se em declínio a partir de 1940. Contudo, a pro dução de café mostra evolução irregular, considerando-se estes' dados. Há ligeira retomada em 1960, aproximando-se daquela de 1940, para em 1970 apresentar a sua menor produção, a qual ind1 ca o forte decilnio da cultura. (Quadro 10)

Ao lado aestes declínios há a expansãu de outras ativi dades: bovinocultura e avicultura. A primeira expande-se à par tir dos fins da década de 1940, definindo um domínto na economia do município que irá permanecer até os fins da década de 1960, 
POPULAÇÃo: - Nascimentos, óbitos, Saldo Vegetativo, Saldo Real e Emigração Período de 1940 a 1970

Municipio de Paraguaçu Paulista

Tabela 19

\begin{tabular}{|c|c|c|c|c|c|c|c|c|c|c|c|}
\hline \multirow[b]{2}{*}{ Períodos } & \multirow{2}{*}{$\begin{array}{l}\text { Popu } 1 \text { a- } \\
\text { ção to- } \\
\text { tal }\end{array}$} & \multicolumn{2}{|c|}{ Nascimentos } & \multicolumn{2}{|c|}{ Obitos } & \multicolumn{2}{|c|}{ Saldo Vegetativo } & \multicolumn{2}{|c|}{ Saldo Real } & \multicolumn{2}{|c|}{ Emigração } \\
\hline & & $\begin{array}{l}\text { Absolu- } \\
\text { to na } \\
\text { década }\end{array}$ & $z$ & $\begin{array}{l}\text { Absolu- } \\
\text { to na na } \\
\text { década }\end{array}$ & $z$ & $\begin{array}{l}\text { Absolu- } \\
\text { to na } \\
\text { década }\end{array}$ & $\begin{array}{l}7 \text { em re } \\
1 \text { ação } \\
\text { pop.tot. }\end{array}$ & $\begin{array}{l}\text { Absolu- } \\
\text { to na } \\
\text { década }\end{array}$ & $\begin{array}{l}\text { \% em re- } \\
\text { lação a } \\
\text { pop. tot. }\end{array}$ & $\begin{array}{l}\text { Absoluta } \\
\text { na dé- } \\
\text { cada }\end{array}$ & $\begin{array}{l}z \text { em re- } \\
\text { lação a } \\
\text { pop.tot. }\end{array}$ \\
\hline 1940 & 24.358 & & & & & & & & & & \\
\hline 1950 & 24.543 & 10.457 & 42,93 & 3.980 & 16,34 & 6.477 & 26,59 & 185 & 0,76 & 6.292 & 25,83 \\
\hline 1960 & 24.078 & 9.187 & 37,43 & 2,941 & 11,98 & 6.246 & 25,45 & -465 & $-1,89$ & 6.711 & 27,34 \\
\hline 1970 & 23.343 & 7.779 & 32,30 & 2.411 & 10,01 & 5.368 & 22,29 & -916 & $-3,80$ & 6.284 & 26,10 \\
\hline TOTAL & & 27.423 & & 9.332 & & 18.091 & & -1.015 & & 19.102 & \\
\hline
\end{tabular}

Fontes: Censos de $1940,1950,1960$ e 1970

Departamento Estadual de EstaÉrstica-SP. 
POPULAÇÃO : Crescimento Vegetativo e aumer.tos que deveriam ocorrer na população urbana e rural

Município de Paraguaçu Paulista - 1940 a 1970

Tabela 19A

\begin{tabular}{|c|c|c|c|c|c|c|c|}
\hline Períodos & $\begin{array}{l}\text { Popù lação } \\
\text { Total }\end{array}$ & $\begin{array}{l}\text { Crescimento } \\
\text { Vegetativo }\end{array}$ & $\begin{array}{l}\text { Taxa de cres } \\
\text { cimento ve- } \\
\text { getativo por } \\
1.000\end{array}$ & $\begin{array}{l}\text { Fopulação } \\
\text { Urbana }\end{array}$ & $\begin{array}{l}\text { Aumento que } \\
\text { deveria ocor } \\
\text { rer na popu } \\
\text { lação unbana }\end{array}$ & $\begin{array}{c}\text { População } \\
\text { Rural }\end{array}$ & $\begin{array}{l}\text { Aumento que } \\
\text { deveria cico: } \\
\text { rer na popù } \\
\text { lação rurai }\end{array}$ \\
\hline 1940 & 24.358 & & & 5.297 & & 19.061 & \\
\hline $1940 / 50$ & $\because \quad \Sigma \vdots$ & 6.477 & 26,6 & & 1.409 & & 5.070 \\
\hline 1950 & 24.543 & & & 7.609 & & 16.934 & \\
\hline $1950 / 60$ & & 6.246 & 25,4 & & 1.932 & & 4.301 \\
\hline 1960 & 24.078 & & '. & 12.252 & & 11.826 & \\
\hline $1960 / 70$ & & 5.368 & 22,3 & & 2.732 & & $2.63 \%$ \\
\hline 1970 & 23.343 & & & 13.981 & & 9.181 & \\
\hline
\end{tabular}

Fontes: Censós de $1940,1950,1960$ e 1970.Departamento Estadual de Estatísti ca do Estado de São Paulo.- 


\begin{tabular}{|c|c|c|c|c|}
\hline & 1940 & 1950 & 1960 & 1970 \\
\hline AGRICULTURA • & 27.460 & 17.824 & 18.942 & 11.927 \\
\hline PASTAGENS & 22.778 & 34.705 & 60.702 & 67.066 \\
\hline MATAS & 42.502 & 20.839 & 11.199 & 13.800 \\
\hline TERRAS NÃO EXPLORADAS & 20.354 & 14.589 & 2.353 & 5.386 \\
\hline TERRAS INIPRODUTIVAS & 4.271 & - & - & - \\
\hline
\end{tabular}

$$
\begin{aligned}
& \text { OBS : Agricultura: permanente e temporärla } \\
& \text { Pastagens : naturals e artificials } \\
& \text { Matas : naturals e reflorestamentos }
\end{aligned}
$$

FONTE - Censos.

Produçōes dos principais produtos agrícolas

Paraguaçu Paulista - 1940 a 1970. Quadro 10

\begin{tabular}{|ll|c|c|c|c|}
\hline & & 1940 & 1950 & 1960 & 1970 \\
\hline ALGODS̃o (arrobas) & 181.600 & 276.733 & 234.400 & 120.000 \\
\hdashline CAFE & (arrobas) & 229.800 & 186.933 & 22.3 .400 & 37.500 \\
BOVINOS (cabeças) & 14.698 & 29.210 & $44.41 \dot{1}$ & 39.855 \\
SUINOS (cabcças) & 18.953 & 9.894 & 9.316 & 5.633 \\
AVES (cabeças) & 65.668 & 39.735 & 79.192 & 169.619 \\
\hline
\end{tabular}

FONTE - Censos. 
quando novas culturas - trigo e soja - começam a desenvolver-se. A avicultura, embora tradicional em Paraguaçu Paulista, colocan do-o como uma das importantes áreas produtoras de ovos do oeste do Estado de São Paulo, tem a sua expansão marcada a partir da década de 1950, constituindo atualmente a atividade de maior ren da bruta no municipio ( 31 ).

Portanto, a partir de 1940 , os números totais da popula ção municipal apresentando-se inalteráveis, caracterizam, nos últimos 30 anos, um processo emigratório marcante, uma vez que praticamente o saldo vegetativo e ịmigrantes não são incorpora dos à população.

As transformaçōes ocorridas na economia municipal definem um esvaziamento intenso da zona rural até o início dos anos 60 , correspondendo a um crescimento urbano, o que significa que a cidade absorveu boa parcela destes rurais. Entretanto, aqueles que deixam o campo não o fazem apenas em favor de Paraguaçu Pau lista, mas dirigem-se,também, para centros maiores e outros po los tais como o Norte do Paraná, Sul de Mato Grosso, atraídos pe lo aceno de melhores condições de vida.

Nos anos 60 , a zona rural tendo se esvaziado ao limite Eil quie ueia permanecem apenas aqueies que a exploram diretamente, e a economia urbana nãò tendo condições de gerar novas oportuní dades, uma vez que os seus setores de atividades fundamentam-se no setor primārio, resulta em diminuição das saídas dos rurais em direção ao centro urbano paraguaçuense, enquanto que este vião possuindo condições de absorver os poucos que chegam ou de re ter o seu crescimento vegetativo, entra em processo de perda po pulacional.

\footnotetext{
( 31 )- Dlano Hunicipal de Desenvoivimento Rural. Secretaria da Agricultura do Estado de São Paulo - CATI, Prefeitu ra Municipal de Paraguaçu Paulista, 1971 - pägina $8 \overline{1}$ e seguinte.-
} 


\subsection{Estrutura da População e Pirâmide das Idades}

Os censos demográficos e a amostragem realizada, permitem verificar que na população de Paraguaçu Paulista ocorre predomí nio do sexo masculino.

Entretanto, esta superioridade masculina, bastante repre sentativa em 1940 (7,138), apresenta um declínio considerável, a parecendo em $1970 \mathrm{com}$ apenas 1,988 a mals que o sexo feminino.Ao nivel urbano do Distrito da sede a maior presença do sexo mascu lino ocorre apenas em $1940(5,228)$ para nos Censos seguintes a presentar-se inferior $(1950-1,348,1970-0,823)$, sendo que esta última aparece tanto na Sinopse Preliminar do Censo de 1970 como na amostragem realizada em 1971/72). (Quadro 11)

Participação percentual da população quanto ao sexo.

Município'e Distrito da Sede (Urbana e rural)

Paraguaçu Paulista - 1940, 1950, 1970 e 1971/72

Quadro 11

\begin{tabular}{|c|c|c|c|c|c|c|c|c|c|}
\hline \multirow{3}{*}{.} & \multirow{2}{*}{\multicolumn{3}{|c|}{ Município }} & \multicolumn{3}{|c|}{ Distrito da. } & \multicolumn{3}{|l|}{ sede } \\
\hline & & & & \multicolumn{3}{|c|}{$U \mathbf{U} \quad \mathrm{b} \quad \mathrm{a} \cap 0$} & \multicolumn{3}{|c|}{ R u r a I } \\
\hline & Masc. & Fem. & 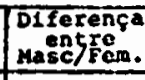 & Masc. & Fem. & $\begin{array}{l}\text { Diferenca } \\
\text { entre } \\
\text { masc/Fem. }\end{array}$ & Masc. & Fem. & $\begin{array}{l}\text { Diferenca } \\
\text { Masc/rem. }\end{array}$ \\
\hline 1940 & 53,56 & 46,43 & 7,13 & 52,61 & 47,39 & 5,22 & 54,00 & 46,00 & 8,00 \\
\hline 1950 & 52,16 & $47 ; 84$ & 4,32 & 49,33 & 50,67 & 1.34 & 52,94 & 47,06 & 5,88 \\
\hline 1970 & 50,82 & 49,18 & 1,64 & 49,59 & 50,41 & 0,82 & 53,28 & 46,72 & 6,56 \\
\hline $\begin{array}{c}\text { Amostrag. } \\
71 / 72\end{array}$ & - & - & - & 49,58 & 50,42 & 0,84 & - & - & \\
\hline
\end{tabular}

Fonte: Censos de 1940,1950

Sinopse Preliminar do Censo de 1970

Amostragem 1971/72

A pirâmide das idades de 1970 e a projeção dos perfis das pirāmides de 1940 e 1950, e a observação do quadro 12 permitem verificar que em 1940 a superioridade masculina è definida pelas faixas etárias do grupo de 20 a 49 anos, para em 1970 apresentar superioridade feminina, exceto a faixa de 40 a 49 anos que ainda tem para os homens ligeira predominância. (Figuras 1 e 2 )

Nas demais faixas etárias a superioridade masculina è pou co sentida, havendo um quase equilíbrio, com exceção da faixa de 0 a 9 anos em 1940, com $+1,128$. Esta superioridade em todo o pe riodo tem a sua presença relativa acentuada em $0,688(50$ a 59 anos em 1950). 
A amostragem real1zada em 1971/72 encontrou comportamento semelhatne na faixa etáría de 10 a 19 anos onde é maior a pre sença feminina. (Quadro 12)

\begin{tabular}{|c|c|c|c|c|c|c|c|c|}
\hline \multicolumn{9}{|c|}{$\begin{array}{l}\text { População do municipio de Paraguaçu } \\
\text { etaria } 1940,1950,1970 \text { e população } \\
\text { gem de } 1971 / 72 \\
\text { Paraguaçu Paulista - } 1972\end{array}$} \\
\hline \multirow{2}{*}{$\begin{array}{l}\text { FAIXA } \\
\text { ETÃRIA }\end{array}$} & \multirow[t]{2}{*}{19} & \multirow{2}{*}{$\frac{40}{F}$} & \multicolumn{2}{|c|}{1950} & \multicolumn{2}{|c|}{1970} & \multicolumn{2}{|c|}{ Amostragem } \\
\hline & & & $\mathbf{M}$ & $\vec{E}$ & $M$ & $\mathbf{F}$ & M & $\mathbf{F}$ \\
\hline $\begin{array}{lll}0 & \text { a } & 9\end{array}$ & 16,45 & 15,33 & 16,32 & 15,39 & 13,95 & 13,49 & 11,19 & 10,35 \\
\hline 10 a 19 & 11,26 & 11,37 & 11,44 & 11,43 & 12,20 & 11,93 & 12,60 & 13,58 \\
\hline 20 a 29 & 10,28 & 8,34 & 8,82 & 8,60 & 7,15 & 7,56 & 7,83 & 8,43 \\
\hline 30 a 39 & 6,97 & 5,26 & 6,56 & 5,51 & 5,56 & 5,74 & 5,60 & 6,37 \\
\hline 40 a 49 & 4,84 & 3,38 & 4,38 & 3,51 & 4,93 & 4,64 & 5,25 & $5 ; 40$ \\
\hline $\begin{array}{lll}50 & \text { a } & 59\end{array}$ & 2,27 & 1,63 & 2,63 & 1,95 & 3,47 & 2,90 & 3,68 & 3,45 \\
\hline 60 a 69 & 1,06 & 0,75 & 1,31 & 0,93 & 2,11 & 1,61 & 2,32 & 1,78 \\
\hline+ de 70 & 0,41 & 0,35 & 0,62 & 0,45 & 1.26 & 1,08 & 1.10 & 1,07 \\
\hline Ignor. & 0,02 & 0,03 & 0,03 & 0,07 & 0,19 & 0,24 & - & - \\
\hline TOTAL & 53,56 & 46,44 & 52,16 & 47,84 & 50,82 & 49,18 & 49,57 & 50,43 \\
\hline
\end{tabular}

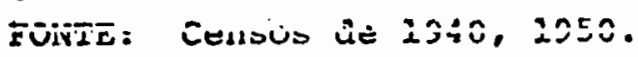

sinopse preliminar do Censo de 1970.

Amostragem $1971 / 1972$.

Considerando-se as idades, verifica-se que a estrutura é tiplca de uma população jovem nitidamente preponderante sobre a dos adultos e velhos.

Entretanto, considerando-se os três grupos principais de Idade, ou seja, o dos jovens ( 0 a 19 anos), o dos adultos (20 a 59 anos) e dos velhos (mais de 60 anos), dentro do período 1940 a 1970, verifica-se que há uma tendência ao envelhecimento da po pulação. (Quadro 13)

Participação percentual dos grupos de idade na composição da população. Município e amostragem urbana.

Paraguáçu Paulista - 1940 a 1970 e $1971 / 72$ Quadro 13

\begin{tabular}{|c|c|c|c|c|}
\hline PERIODOS & $0 \begin{array}{c}\text { a } 19 \\
\text { anos }\end{array}$ & $\begin{array}{c}20 \text { a } 39 \\
\text { anos }\end{array}$ & $\begin{array}{c}40 \\
\text { anos } 59\end{array}$ & $\begin{array}{c}\text { de } 60 \\
\text { anos }\end{array}$ \\
\hline 1940 & 54,45 & 30,86 & 12,13 & 2,56 \\
1950 & 54,66 & 29,53 & 12,49 & 3,32 \\
1960 & 53,16 & 28,54 & 13,63 & 4,64 \\
1970 & 51,79 & 26,12 & 16,01 & 6,08 \\
Amostragem & 47,12 & 28,23 & 17,78 & 6,27 \\
\hline
\end{tabular}




\section{PIRÂMIOES dE IDADES}

MUNICÍPIO dE PARAgUAGU PAULISTA

1070 - PERFIS DE $1040 \cdot 1980$

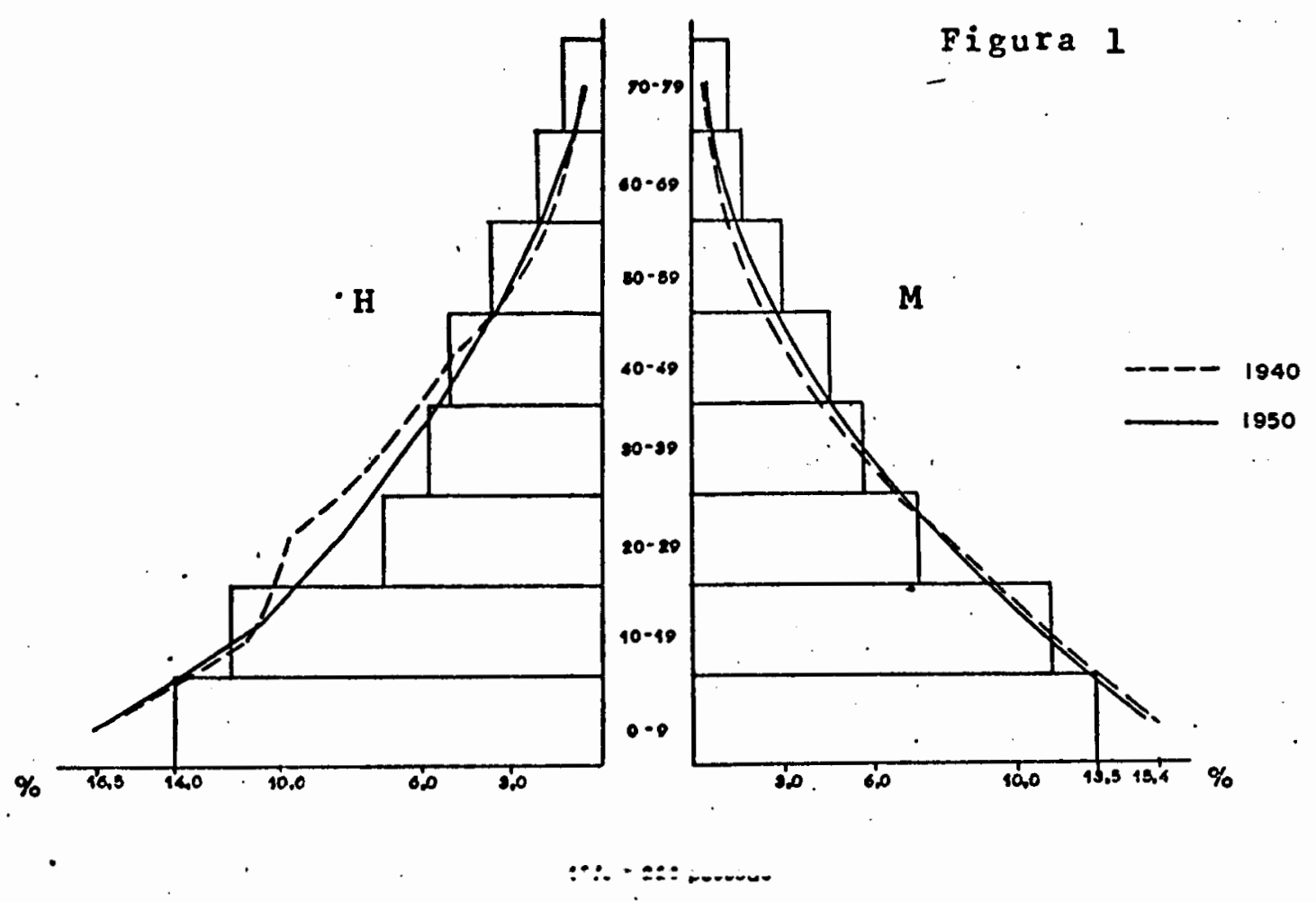

POPULACÃo da CIDADE dE PARAgUAGU PAULISTA LEVANTAMENTO DE $1871 / 72$

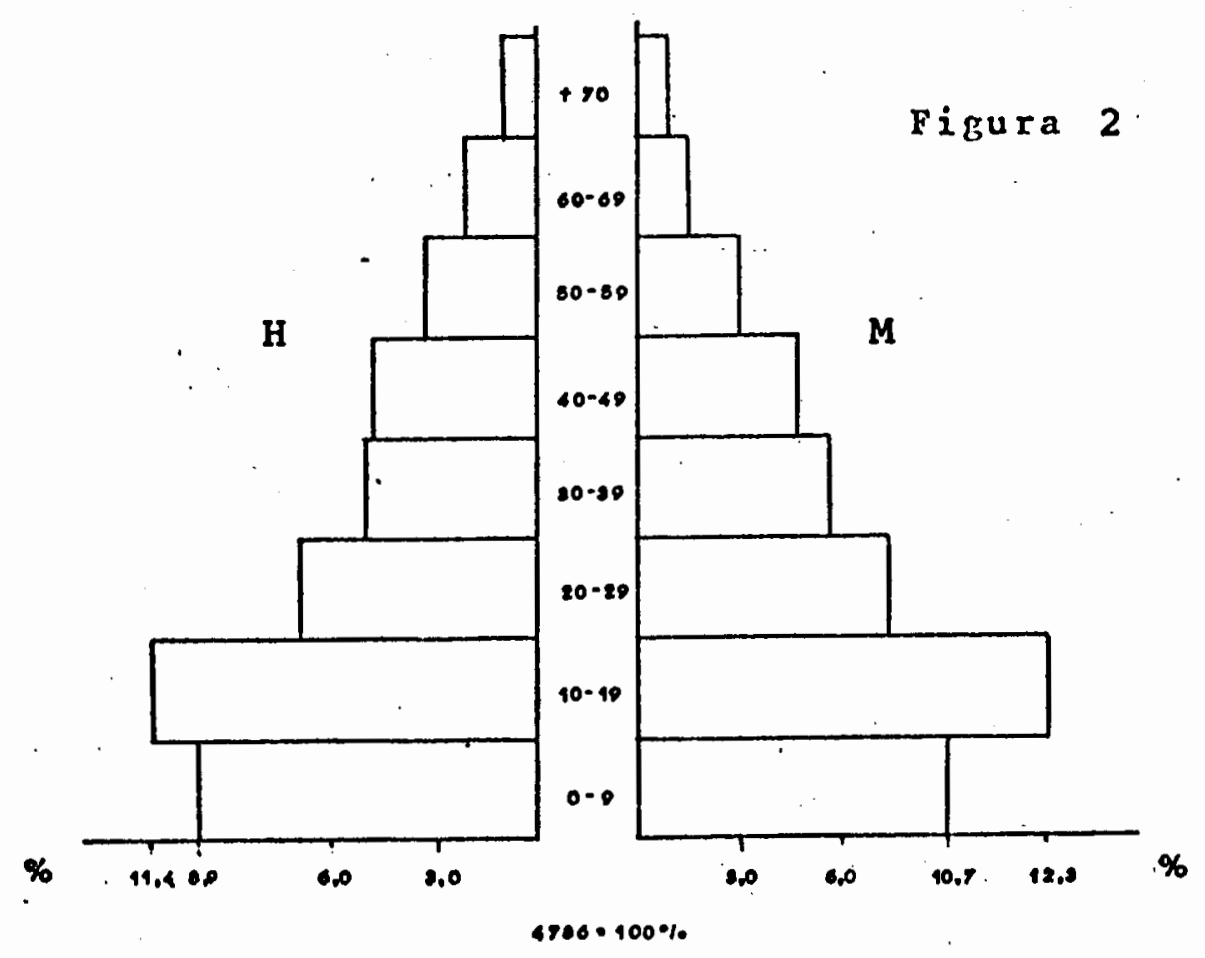


Observa-se, inicialmente, uma diminuição do grupo dos jo vens, embora, entre 1940 e 1950 apresente pequeno crescimento. o grupo dos adultos, com ligeira predominância para o censo de 1970, apresenta, nos decênios seguintes mais ou menos a mesma importância. Contudo, analisando-se mais em detalhe, verifica se uma diminuição da faixa adulta mais jovem (20 a 39 anos) que apresenta a mais expressiva alteração com $-4,748$ ao lado do au mento da faixa adulta mais 1dosa (40-59 anos). Finalmente o gru po de mais de 60 anos tem sua participação aumentada a cada dé cênio.

Estes fatos apresentam-se mais acentuados quando vistos para a população urbana, definida pela amostragem realizada.Ape nás como exceção o grupo de 20 a 39 anos mostra-se mais numero so segundo o censo de 1970, graças a presença feminina. (Quadros 12 e 13.

A pirâmide das idades de 1970 e perfis das de 1940 e 50, mostram esta juventude da população, a sua tendência ao envelhe cimento bem como as diferenças que surgiram no período analisa do.

A sua base ampla, afunilando-se rapidamente terminando

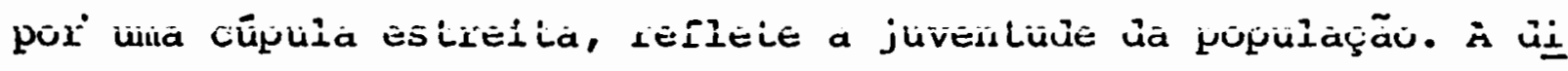
minuição do grupo dos jovens, das primeiras faixas dos adultos e a ampliação dos grupos mais idosos, aspectos observados prin cipalmente a partir de 1950, demonstram as tendências do enve lhecimento.

Estas dịferenças serão melhor apreendidas, analisando-se o comportamento de cada sexo na composição da pirâmide.

o sexo feminino apresenta certo equilibrio na composição entre 1940-50, traduzido pela simetria dos perfis. Em 1970 mos tra uma ruptura neste equilíbrio, com ligeiro alargamento da cúpula da pirâmide a partir da faixa de 40 a 49 anos. Na base há o estreitamento, fruto da diminuição que ocorre na faixa de 0 a 9 anos. (Quadro 12, Figura 1)

Entretanto, as alterações são mais marcantes em relação ao sexo masculino. Os perfis de 1940 e 1950 são semelhantes nas primeiras faixas etárias ( 0 a 9 e 10 a 19 anos) demonstrando se melhança nümérica desta população nas duas datas. Na faixa se guinte (20 a 29 anos) tem-se uma quebra da simetria face à dimi nuị̧ão da população deste grupo etário em 1950. As demais fai xas etárias também decrescem, o que significa alterações na com posição da pirâmide de 1950. Enitretanto estas não são expressí 
vas, o que é demonstrado pela assimetria pouco acentuada dos per fis. (Quadro 12, Figura 1).

Somente em 1970 é que os perfis são quebrados desde a bạ se ( 0 a 19 anos), onde a segunda faixa etária (10-19 anos) mos tra crescimento desta população em relação aos anos de 1940 e 1950. Contudo, após este grupo etārio, a pirâmide apresenta uma ruptura até a faixa de 40 a 49 anos, face à diminuição da popula ção adulta masculina, o que traduz un estrangulamento da pirâmi de, fatos que são marcantes no grupo etário de 20 a 29 anos (Qua dro 12, Figura 1).

Após a faixa dos 40-49 anos, os perfis de 1940-50 e a pí rậmide de 1970, tornam-se simétricos, mas com crescimento, consi derando-se a primeira data. (Nuadro 12, Figura 1)

A pirâmide construída com os dados da amostragem da popu lação urḅana (1971/72) traz as mesmas características daquela do municipio em 1970, com um aspecto em destaque: o estreitamento da base ( 0 a 9 anos) apresenta-se mais profundo, tanto para o se xo masculino quanto para o feminino. (Quadro 12, Figura 2).

\section{3. Mortalidade e Natalidade}

Estes fatos serão analisados tendo-se como elementos os dados obtidos na Secretaria de Economia e Planejamento do Estado de São Paulo - Departamento Estadual de Estatística, População e Movimento do Registro Civil, Censos Demográficos e de levantamen tos realizados. no Centro de Saúde de Paraguaçu Paulista.

Procurar-se-á analisá-los em dois niveis: ao nível de mu nicípio e ao nível do Distrito da sède, tentando-se, através do segundo, aproximar-se o mais possível do nūcleo urbano principal, objeto deste trabalho.

Complementando-se estas observaçōes, definiu-se o perío do de 1940 e 1970 a ser analisado.

Os resultados obtidos para o último decênio - 1960/1970 colocam o municipio de Paraguaçu Paulista na categoria de ".fraca mortalidade" enquanto que o Distrito da Séde apresenta-se como de "média mortalidade" ( 32 )

Considerando-se 0 período todo, verifica-se un declínio da mortalidade. Entretanto, tem-se um declínio mais acentuado no

(32) Hugon, Paul - Demografia Brasileira. São Paulo, Editora da U.S.P. - 1973 - pägina 110 . 
distrito da sede, uma vez que este apresenta um aumento de popu lação enquanto que o município, neste aspecto, é caracterizado por uma relativa estabilidade. Outro fato que se observa è que tanto para um.quanto para outro espaço, a queda da mortalidade é mais expressiva do primeiro para o segundo decênio.

Ao lado desta mortalidade geral, procurou-se analisar a mortalidade infantil, visto que ela tem importância e está intí mamente ligada à geral. (33)

o comportamento da mortalidade infantil è semelhante ao da mortalidade geral. Igualmente assiste-se a uma redução sensí vel nos índices desta no período todo, mais expressivo do pri meiro para o segundo decênio e mais acentuado no Distrito da sé de.

Entretanto, tomando-se o último decênio, tem-se para am bos os fatos; tanto no município quanto no distrito da sede, um declínio nos seus números até 1965, crescéendo nos anos subseqüen tes não átinge porēm em nenhum deles, os níveis dos anos anterio res. Deve-se apenas atentar para o fato de que, embora neste de cênio verifique-se èste declínio, os números e as taxas expressos pela mortalidade infantil, a colocam em um e outro espaço, em niveis que podemos considerar elevados. (Tabela 20, Figura 3 ).(34)

Quanto à natalidade, no conjunto, encontra-se em declínio. Entretanto, quando vista ao nível do município e Distrito da se de, algumas variações aparecem.

Em térmos de taxas brutas, há declínio mais acentuado no Distrito da sede do primeiro para o segundo decênto, enquanto que este fato ocorre no município do segundo para o terceiro decê nio. (Tabela 20 , figura 3)

Em valores absolutos hã diminuição de decênio para decê n1o, no município, enquanto que no distrito da sede há semelhan te ocorriencla entre o primeiro e o segundo período, com retoma da entre 1960/70. (Tabela 20, figura 3)

Observa-se ainda que as taxas de natalidade são, para 0 período todo, mais altas no distrito da sede.

(33) Beaujeu, Garnier Jaćqueline - Geografia da População - São Paulo, Editora da U.S.P. - 1971 - pág. 108 e 116.

(34) A mortalidade infantil no Estado de são Paulo apresentou pa $\mathrm{ra} 1965,66,67,68$ e 69 , Indices de $69,4 \% \%, 73,8 \%$, $74,3^{\circ} \%$ e $83,8 \%$ respectivamente enquanto que Paragugçu Paulista apresentou $76,0 \%, 00,108,0 \% / 00,99,0 \% 00,105,0 \%$ e $101,0 \% \%$. 
NATALIDADE, MORTALIDADE, MORTALIDADE INFANTI:, E CRESCIMENTO NATURAL - VALORES ABSOLUTOS E TAXAS BRUTAS PARA DECENIOS DE 1940 A 1970 - MUNICI:?IO E DISTRITO DA SEDE DE PARAGUAÇU PAULISTA

Tabela- 20

\begin{tabular}{|c|c|c|c|c|c|c|c|c|c|c|}
\hline & DECENIO & $\begin{array}{l}\text { População- } \\
\text { méd1a no } \\
\text { perlodo }\end{array}$ & $\begin{array}{l}\text { Total de } \\
\text { nascimentos } \\
\text { no periodo }\end{array}$ & $\begin{array}{l}\text { Taxa bruta } \\
\text { de natalí } \\
\text { dade } p / 1000\end{array}$ & $\begin{array}{l}\text { Total de } \\
\text { obitos no } \\
\text { periodo }\end{array}$ & $\begin{array}{l}\text { raxa bruta } \\
\text { de mortal1- } \\
\text { dade } p / 1000\end{array}$ & $\begin{array}{l}\text { Total de } \\
\text { ób1tos de } \\
-1 \text { ano. }\end{array}$ & $\begin{array}{l}\text { Taxa bruta } \\
\text { de mortal1- } \\
\text { dade infan- } \\
\text { t11 p/1.000 }\end{array}$ & $\begin{array}{l}\text { Crescimento } \\
\text { vegetativo }\end{array}$ & $\begin{array}{l}\text { Taxa de cres } \\
\text { cimento ve- } \\
\text { getativo - } \\
\text { por } 1.000\end{array}$ \\
\hline 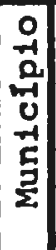 & $\begin{array}{l}1940 / 50 \\
1950 / 60 \\
1960 / 70\end{array}$ & $\begin{array}{l}24.450 \\
24.310 \\
23.620^{\star}\end{array}$ & $\begin{array}{c}10.457 \\
9.187 \\
7.694^{\star}\end{array}$ & $\begin{array}{l}42,76 \\
37,79 \\
32,57\end{array}$ & $\begin{array}{l}3.984 \\
2.941 \\
2.418\end{array}$ & $\begin{array}{l}16,29 \\
12,09 \\
10,24\end{array}$ & $\begin{array}{r}1.525 \\
1.057 \\
775\end{array}$ & $\begin{array}{l}145,8 \\
115,0 \\
100,7\end{array}$ & $\begin{array}{l}6.473 \\
6.246 \\
5.276\end{array}$ & $\begin{array}{l}26,47 \\
25,69 \\
22,34\end{array}$ \\
\hline $\begin{array}{l}\stackrel{0}{0} \\
\text { os } \\
\dot{4} \\
\stackrel{0}{0} \\
\dot{0}\end{array}$ & $\begin{array}{l}1940 / 50 \\
1950 / 60 \\
1960 / 70\end{array}$ & $\begin{array}{l}11.344 \\
13.921 \\
15.982\end{array}$ & $\begin{array}{l}6.054 \\
5.858 \\
6.059\end{array}$ & $\begin{array}{l}53,37 \\
42,08 \\
37,91\end{array}$ & $\begin{array}{l}2.418 \\
2.204 \\
2.098\end{array}$ & $\begin{array}{l}21,31 \\
15,83 \\
13,13\end{array}$ & $\begin{array}{l}848 \\
704 \\
662\end{array}$ & $\begin{array}{l}140,1 \\
120,1 \\
109,2\end{array}$ & $\begin{array}{l}3.636 \\
3.654 \\
3.961\end{array}$ & $\begin{array}{l}32,06 \\
26,24 \\
24,78\end{array}$ \\
\hline
\end{tabular}

(*) - Inclusive o municípto do Borá

FONMES: Censos de $1940,1950,1960$ e 1970

Departamento Estadual de Estatística du Estado de são Paulo 
paraquacu paulista

EVOLUgão oa ropulagão. matalidade e mortalioade no municlpio E mo DIsTAITO SEDE

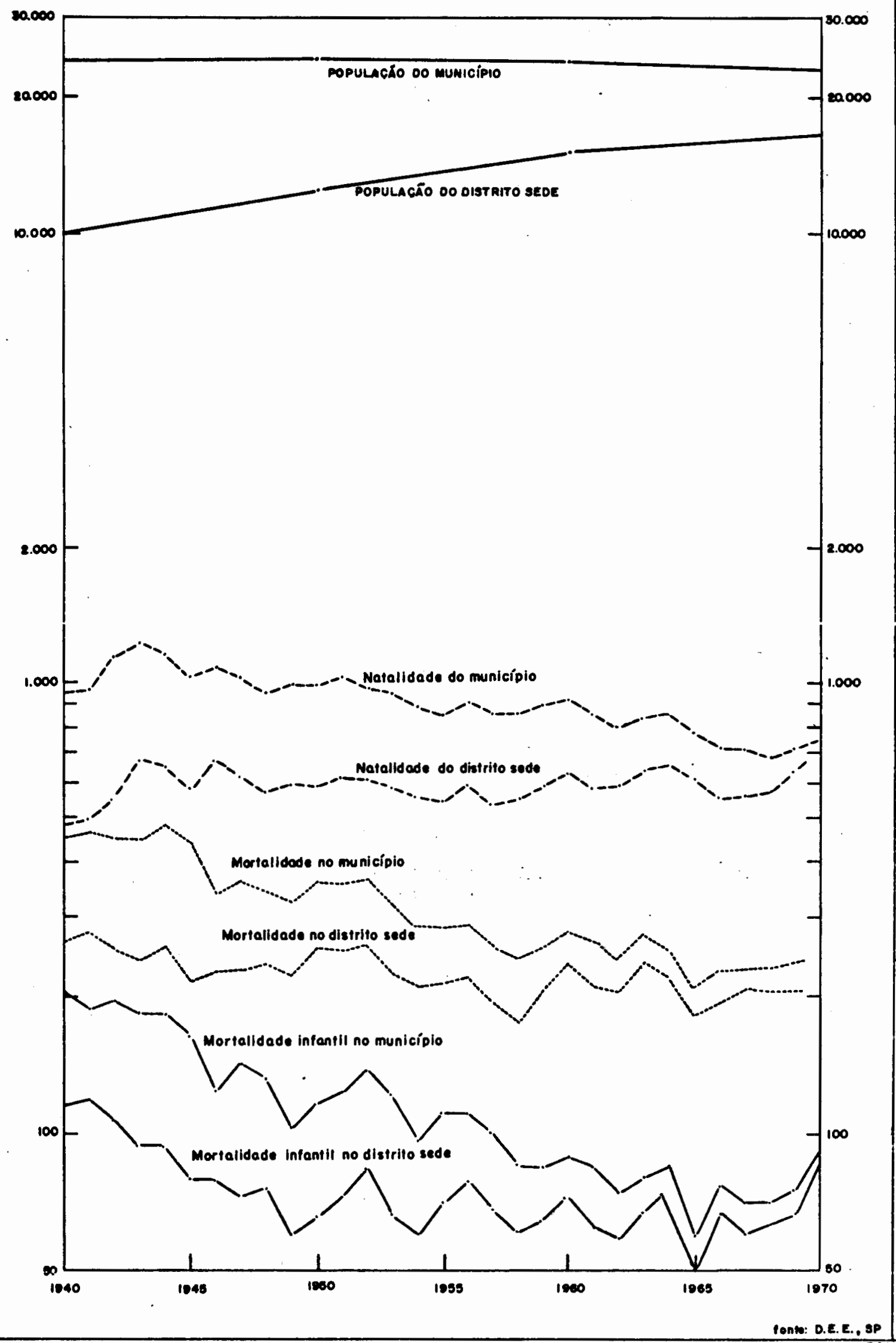


Procurar-se-á, com algumas hipóteses, explicações para a evolução e comportamento da mortalidade e natalidade.

o declínio da mortalidade geral, acentuado principalmen te do primeiro para o segundo decênio, é resultado da implanta ção e melhoria do equipamento médico-hospitalar e de sanea mento básico da cidade. Na década de 1940/1950, o centro urbano de Paraguaçu Paulista, conseqüentemente o município, fol benefi ciado pela implantaçāo de um Posto de Saúde, um Hospital e uma Casa de saúde. ( 35 ). Neste mesmo período, verifica-se a presen ça de 9 médicos (36) e igualmente 9 farmācias. A década seguinte, logo em seu inicio tem a implantação de um Posto de Puericultura e serviços de āgua e esgoto(37), beneficiando diretamente a popu lação urbana, que nesta década apresenta o seu maior crescimento. Quanto à mortalidade infantil, que se apresenta elevada , embora tendendo a declinar decênio após decênio com pequena reto mada nos últimos anos, como já se verificou, nos leva a conside rações que estão relacionadas, em parte com aspectos vistos ante riormente.

Uma das causas deste comportamento do fenômeno está, no fato de que parcela desta população situa-se em baixo nível eco nömico, afetando, por consequëncia, as condiçoes de vida de gran de número de mães e crianças. Intrinsecamente ligado a este, te mos o deslocamento da população rural para a cidade, cuja impor tância não se prende ao fenômeno do exôdo rural em si, mas pelas condições "que esta população apresentarā na cidade em termos pro fissionais e de localização, isto é, serão os bóias-frias ou subempregados: indo morar nos setores mais pobres da zona urbana tais como a Barra Funda e Vila Nova (38). A presença desta popu lação com baixo nível econômico e em maioria, nestes setores ur

(35) Hospital de Caridade de Paraguaçu Paulista e Casa de Saúde Santa Inêz, implantados em 1947. Posto de Saúde - Secreta ria da Saúde do Estado de São Paulo, implantado em 1942.

(36) Anterior à implantação do Hospital de Caridade e Casa de Saúde, havia na cidade 5 médicos, sendo 4 de clínica geral e um radiologista. Após a implantação dêstes, o corpo médi co passa a ser composto por 2 pediatras, 1 otorrino, 1 rá diologista e 4 de clínica geral.

(37) Serviço de água e eśgotos, implantados em 1951 e 1952. Pos to de Puericultura implantado pouco depois.

(38) Bairro e loteamento da periferia, de baixo padrão de vida onde predominam velhas casas de madeira, presença signifi cativa de barracos. Seräo vistos commaiores detalhes no ca pítulo referente à Estrutura Urbana. 
banos, traz como consequiência a ignorância por parte das mães, quanto aos cuidados que devem ser dispensados à criança, destá cando-se o da Imunização adequada através das vacinações (39) ao lado de um pré e pós-natal insatisfatórios (40), bem como da hí giene necessária, ausente na habitação.

Completando o quadro teríamos que considerar o problema da alimentação nesta parcela da população: esta é insuficiente, e inadequada afetando tanto às mães na gestação, quanto à crian ça não só no primeiro ano de vida, mas por um longo tempo.

Quanto à natalidade, ligeiramente elevada, embora em de clínio, tambēm se pode lançar algumas considerações.

Considerando-se a distribuição da população sob os aspec tos rural e urbano, verifica-se que a primeira apresenta sensí vel diminuição de década para década, Indicando um processo emí gratório que beṇeficia em parte a zona urbana. En 1940 a popula ção rural representava 78,25 \& do tọtal populaçional do municí pio; em 1950 esta participação era de 69,08; em 1960, 49,118 e em 1970 - 39,70z. Nas zonas rurais do Distrito da Séde, este as pecto é bastante acentuado a partir de 1960 , cuja participação apresentava-se assim: 1940. - 55,818, $1950-47,878-1960$ - / 25,068 e 1970 - 20,608.

Este crescimento urbano, como conseqưuencia, traz a diminui ção da taxa de natalidade.

Analisando-se a dinâmica da população, verifica-se que a partir de 1950 hã a saída de população, principalmente masculi

(39) Relatório da VIII Caravana ABENIBRA (Associação Nipo-Brasi leira) grupo de universitários de diversas faculdades do interior e da capital, supervisionados por médicos do cor po clínico da Associação. Este relatório, fruto de trabáa 1ho realizado em Paraguaçu Paulista de 18 a 28/01/73, apre senta o nível de conhecimento da população urbana quanto a imunização contra a poliomielite, tétano, varíola, sarampo, difteria, coqueluche, tuberculose. Concluem que "em média, apenas $50,5 \%$ da população urbana mostram suficiente conheci mento das vacinaçöes".

(40) Informações obtidas nos centros de atendimento, tanto à mãe quanto à criança, nos dizem que a preocupaçăo maternal no pré-natal ocorre, em grande parte, apenas no final da gravidez visando a obtenção de guia de internamento para o parto. Entretanto este aspecto (guia de internamento)atual mente não mais existe, bastando que a futura mãe apreseñ te-se.no hospital e terá atendimento. Quanto ao pós-natal, a preocupaçao materna está na busca do leite, quando exis te, que é distribuido no Centro de Saúde, ou na procura deste Centro ou Hospital para a solução de doenças, muitas das vezes em grau avançado. 
na, o que irá refletir na natalidade. Esta saída, característica na faixa de 20 a 39 anos, se faz sentir muito mais na população urbana, principalmente quando se verifica um estreitamento das primeiras faixas etárias em 1970. (Estes fatos podem ser constatados no item referente à Estrutura da População e Pirâmide das Idades, do presente trabalhol.

Entretanto, os dados de natalidade no Distrito da sede pa recem contradizer as considerações acima, lançadas para o núcleo urbano. Contudo, das observações e informações obtidas através dos relatórios do Hospital de Caridade de Paraguaçu Paulista(41) tem-se um aumento do número de partos e conseqüentes nascimentos no.Hospital, havendo por outro lado, uma procura crescente por párte da população da zona rural, alēm daquela do Distrito da Sé de, e da população urbana de poucos recursos, isto é, da perife ria que em períodos não muito distantes, preferiam o ambiente fa miliar para o nascimento das crianças. Outra informação obtida é de que há no hospital uma orientação para o registro imediato destas crianças que aí nascem, sendo na sua grande maioria fei tos no Cartório de Registro Civil do Distrito da Sede.

Assim, a urbanização crescente, mais acentuada entre 1950 e 1960, aỉiada à migração tanto rurai-urbana, quanto urbana-urba na, afetando esta última principalmente a faixa de 20 a 39 anos do sexo-masculino, resultantes de uma débil estrutura econômica urbana incapaz de absorvê-los, e às próprias condicionantes urba nas (limitação de filhos através do controle natural e artifi cial, bem estar, desenvolvimento da educação, desenvolvimento do papel da mulher em atividades profissionais, etc.), são fatores responsáveis pela queda da natalidade.

Por outro lado, a presença dos meios oferecidos pelo se tor de saúde da cidade, carreando para o Cartório de Registro Cí vil da sëde, não só os registros, dos urbanos, mas também dos rurais, explicam a taxa mais elevada da natalidade no Distrito da Sede, distorcendo, inclusive, a realidade da manifestação do fenômeno em seu dimensionamento espacial.

(41) Relatórios anuais do Hospital de Caridade de Paraguaçu Pau1 ista, período compreendido entre 1948 e 1972 . 


\subsection{Proveniência Espacial da População (42)}

A População urbana de Paraguaçu Paulista è constituída por 43,298 de naturais da própria cidade e 56,718 resultantes de movimentos migratórios.

o quadro que se segue demonstra a composição da popula ção de Paraguaçu Paulista quanto às origens:

Quadro 14

Local de Nascimento

Absol.

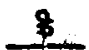

Naturais de Paraguaçu Paulista ...

2.027

43,29

Zona Rural de Parag. Paulista ....

411

8,59

Regiōes do Estado de são Paulo ...

1.616

33,77

Outros Estados Brasileiros .......

580

12,12

Estrangeiro

107

2,23

$\mathbf{T}$

4.786

100,00

Entre os naturais paulistas, uma área se destaca: a soro cabana ( definida por sub-regiōes das regiōes administrativas de Sorocaba, Marília e Presidente Prudente). Esta no conjunto res

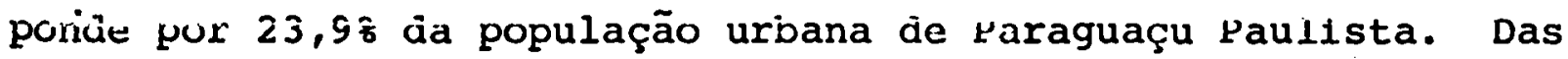
demais ăreas do Estado, sobressai-se a Mogiana (definida pelas sub-regiões: administrativas das regiōes de Campinas e Ribeirão Pretol, cuja participação é de 5,188 na composịção total da po pulação urbana. (Quadro 15)

Quanto aos nascidos em outras unidades da Federação res salta-se a presença de indivíduos provenientes de Minas Gerais $(3,918)$ e Paraná $(2,178)$. Os demais têm pouca expressão, exceto quando se considera o conjunto nordestino que participa com 5,168. (Quadro 15)

o elemento estrangeiro tem pequena participação, mesmo considerado em conjunto, conforme se vê no quadro acima.

Entretanto, esta participação global apresenta diferen ças sensíveis quando vistas aos níveis de Regiões Administrativas do Estado de São Paulo, outros Estados e Países.

Dentro do quadro que divide o Estado de São Paulo em Re giões Administrativas, verifica-se que as cinco malores particí

(42) - As anālises que aqui serāo feitas referem-sc apenas à po pulação urbana da sede (Paraguaçu Paulista). Us resultados obtidos são frutos de levantamentos efetuados em aproxi madamente 1.000 residências abrangendo cerca de 4.800 pes s028 realizados em fins de 1971 e inicio de 1972. Levar -se-a em conta, também, a divisão do Estado em Regióes Administrativas. 
pações, dentro de uma ordem decrescente, cabem às regiões de Ma rilia, Presidente Prudente, Ribeirão Preto, Sorocabana e Campi nas. Para as sub-regiões, as maiores participações recaem sobre aquelas das regiões caracterizadas anterformente, despontando-se as sub-regiōes de Assis, Presidente Prudente, Ourinhos e Avaré. (Tabelas 21 e 22)

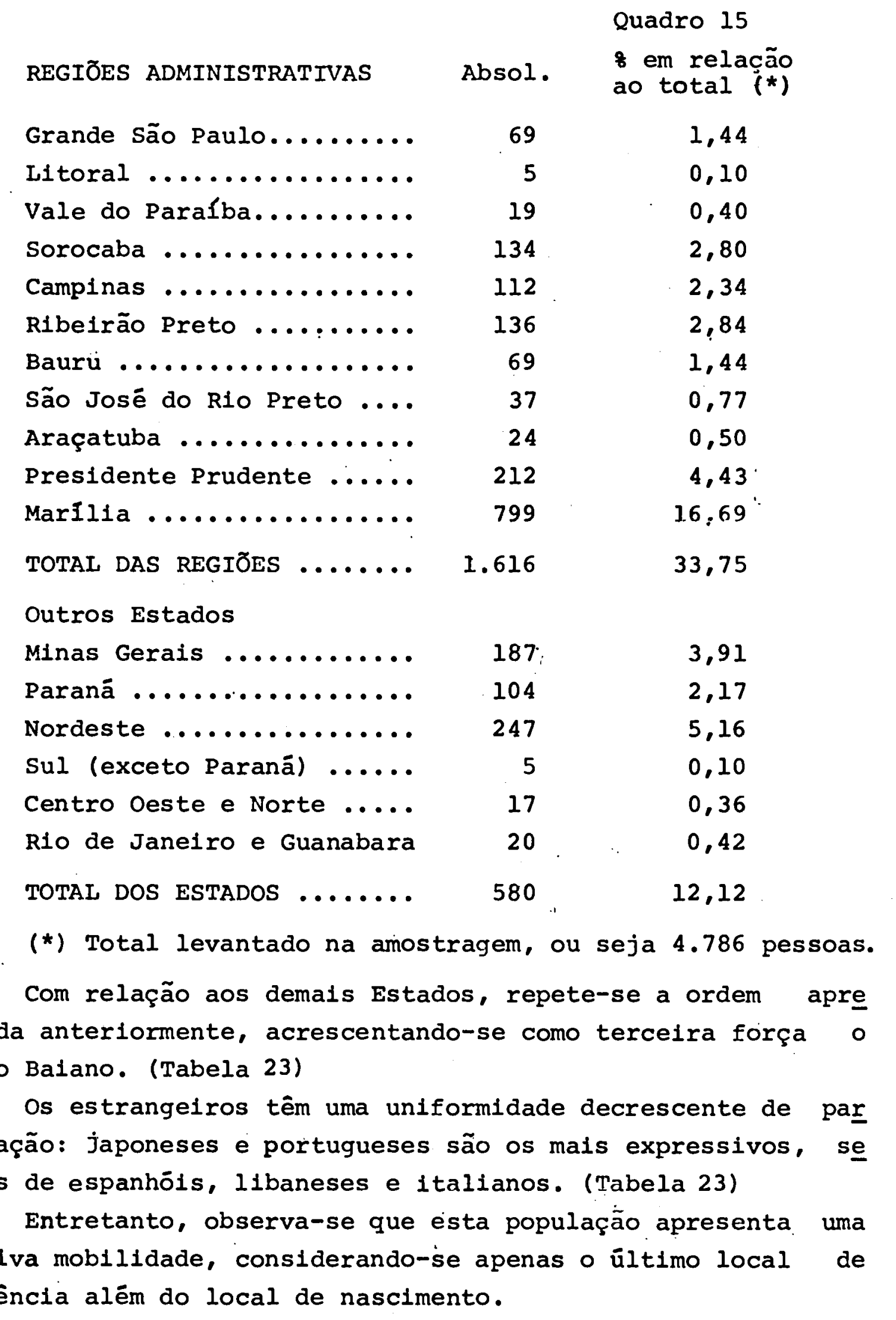


Dos 2.303 não naturais do município de Paraguaçu Paulis ta, 46,248 migram diretamente do local de nascimento, enquanto que os demais apresentam fixaçāo em outras regiōes ou zona ru ral do municipio, antes de virem residir no centro urbano. Nes te conjunto, o local de nascimento como única etapa de migração é marcante para os paulistas, enquanto que a ocorrêncla de uma outra etapa caracteriza aqueles provenientes de outras unidades da Federação ou do estrange1ro. (Quadro 16!

Quadro 16

OLTIMA RESIDENCIA

\begin{tabular}{|c|c|c|c|}
\hline & $\begin{array}{l}\text { no local de } \\
\text { nascimento }\end{array}$ & $\begin{array}{l}\text { em outras } \\
\text { regiōes è } \\
\text { sub-regiōes }\end{array}$ & $\begin{array}{c}\text { Total } \\
-\end{array}$ \\
\hline Paulistas não paraguaçuenses... & 889 & 727 & 1.616 \\
\hline De outros estados ............. & 160 & 420 & 580 \\
\hline Estrangeiros $\ldots \ldots \ldots \ldots \ldots \ldots$ & 16 & 91 & 107 \\
\hline T O T A I $\ldots \ldots \ldots \ldots \ldots \ldots \ldots$ & 1.065 & 1.238 & 2.303 \\
\hline do total & 46,24 & 53,76 & 100,00 \\
\hline
\end{tabular}

Dos 1.616 paulistas não paraguaçuenses fixados, a maio ria é originária do próprio local de nascimento $(55,018)$. Consi derando-se as regiōes do Estado de Säo Paulo, verifica-se que os movimentos migratórios mais intensos se processam de regiōes próximas. Desta forma, a 1la. Região Administrativa de Marília, da qual Paraguaçu Paulista faz parte, contribui com 51,428. Des tes, apenas 14,858 são provenientes de outras regiōes e definem aquela de Marilia como a última ou única etapa antes de se fi xar em Paraguaçu. Em segundo plano encontra-se a 10a. Reglão Ad ministrativa de Presidente Prudente que contribul com 13,748 dos quals 5,208 são provenientes de outras regiōes como etapa ante rior à vinda para Paraguaçu Paulista (43). (Tabela 22)

Do total de 580 nascidos em outros estados brasileiros, os movimentos da população apresentam-se da mesma natureza, al terando-se apenas a posição de Marília que precede aquela do local de nascimento. Desta forma tem-se 27,598 provenientes dos locais de nascimento; 39,318 residiram na região de Marilla e 8,628 na região de Presidente Prudente. (Tabela 23)

Os estrangelros, embora em número pouco expressivos, têm movimentos com as mesmas características dos nacionais não pau

(43)-Destes $5,20 \%$ que correspondew a 84 pessoas, 40 são prove nientes da regiäo de Marília. 


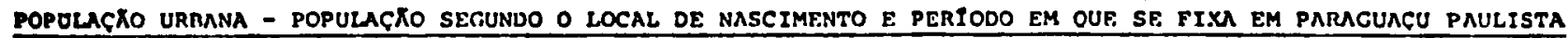
POR REGIKO E SUD-REGIXO ADMINISTRATIVA DO ESTADO DE SR̃O PAULO. (FM NOMEROS ARSOLUTOS E PERCENTACEM)

\begin{tabular}{|c|c|c|c|c|c|c|c|c|c|c|c|c|}
\hline \multirow{3}{*}{ - REGIXO E SUB-REGIXOO } & \multirow{2}{*}{\multicolumn{2}{|c|}{ ete 1940}} & \multirow{2}{*}{\multicolumn{2}{|c|}{$1941 / 50$}} & \multirow{2}{*}{\multicolumn{2}{|c|}{$1951 / 60$}} & \multirow{2}{*}{\multicolumn{2}{|c|}{$1961 / 70$}} & \multicolumn{4}{|c|}{ Tabe!a -21} \\
\hline & & & & & & & & & $\begin{array}{l}\text { sem } \\
\text { def }\end{array}$ & $\begin{array}{r}\text { data } \\
\text { inida }\end{array}$ & T 0 & TA $\boldsymbol{A}$ \\
\hline & abs. & - & $a b s$. & - & abs. & 1 & abs. & $\therefore$ & abs. & 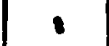 & abs. & 1 \\
\hline Grande são Paulo & 3 & 4,35 & 6 & 8.70 & 11 & 15.94 & 29 & 42.03 & 20 & 28,98 & 69 & 4,27 \\
\hline 2a. Reg1ão - Litora 1 & 1 & 20,00 & 1 & 20.00 & 1 & 20.00 & - & 20.00 & 2 & 40,00 & 5 & 0.31 \\
\hline $\begin{array}{l}\text { 1a. Sub- Santos } \\
\text { 2a. Sub-Vale do R1beira }\end{array}$ & 1 & & $i$ & & 1 & & - & & 2 & & $\begin{array}{l}4 \\
1\end{array}$ & \\
\hline 3a. Reglão - Vale do Paraíba & 1 & 5,26 & 4 & 21.05 & 4 & 21.05 & 9 & 47,37 & 1 & 5.26 & 19 & 1.19 \\
\hline $\begin{array}{l}\text { 1a. Sub- São José dos Campos } \\
\text { 2a. Sub- Taubaté } \\
\text { 3a. Sub- Guaratinquetã }\end{array}$ & $\bar{i}$ & & 2 & & $=$ & & $\frac{3}{6}$ & & $\overline{-}$ & & $\begin{array}{l}9 \\
1 \\
9\end{array}$ & \\
\hline 4a. Reglāo - Sorocaba & 17 & 12.69 & 29 & 21,64 & 23 & 17,16 & 46 & 34,33 & 19 & 14,18 & 134 & 3,29 \\
\hline $\begin{array}{l}\text { la. Sub- Sorocaba } \\
\text { 2a. Sub- Tatuí } \\
\text { 3a. Sub- Itapetininga } \\
\text { 4a. Sub- Capáo Bonito } \\
\text { Sa. Subr Itapeva } \\
\text { 6a. Sub- Avaré } \\
\text { 7a. Sub- Botucatú }\end{array}$ & $\begin{array}{l}1 \\
1 \\
- \\
2 \\
5 \\
5\end{array}$ & & $\begin{array}{r}1 \\
1 \\
- \\
21 \\
5\end{array}$ & . & $\begin{array}{r}\overline{1} \\
1 \\
\overline{3} \\
12 \\
6\end{array}$ & & $\begin{array}{r}6 \\
1 \\
1 \\
1 \\
8 \\
24 \\
5\end{array}$ & & $\begin{array}{l}3 \\
\overline{3} \\
3 \\
9\end{array}$ & & $\begin{array}{r}9 \\
10 \\
2 \\
1 \\
17 \\
65 \\
20\end{array}$ & \\
\hline 58. Regläo - Camplnas & 23 & 20,54 & 22 & 19.64 & 23 & 20.54 & 32 & 28,57 & 12 & 10,71 & 112 & 6.93 \\
\hline $\begin{array}{l}\text { la. Sub- Campinas } \\
\text { 2a. Sub- P1racicaba } \\
\text { 3a. Sub- L1me1ra } \\
\text { 4a. Sub- Rio Claro } \\
\text { 5a. Sub- São João da B.V1sta } \\
\text { 6a. Sub- Casa Branca } \\
\text { 7a. Sub- Jundial } \\
\text { 8a. Sub- Bragança Paul1sta }\end{array}$ & $\begin{array}{l}4 \\
4 \\
6 \\
1 \\
6 \\
1 \\
2 \\
1\end{array}$ & & $\begin{array}{l}6 \\
2 \\
5 \\
1 \\
2 \\
3 \\
1 \\
2\end{array}$ & . & $\begin{array}{l}7 \\
3 \\
2 \\
2 \\
4 \\
2 \\
2 \\
1\end{array}$ & . & $\begin{array}{l}7 \\
4 \\
2 \\
8 \\
4 \\
3 \\
\end{array}$ & & $\begin{array}{l}2 \\
2 \\
3 \\
3 \\
1 \\
-1 \\
-1\end{array}$ & . & $\begin{array}{r}26 \\
15 \\
20 \\
9 \\
21 \\
10 \\
7 \\
4\end{array}$ & . \\
\hline 6a. Reglāo - Ribclrăo Preto & 40 & 29.41 & 26 & 19,12 & 24 & 17.65 & 26 & 19,12 & 20 & 14,70 & 136 & 8,42 \\
\hline 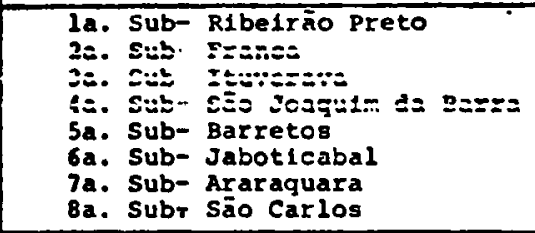 & $\begin{array}{r}13 \\
\vdots \\
\vdots \\
14 \\
6 \\
-\end{array}$ & & $\begin{array}{r}4 \\
2 \\
- \\
1 \\
14 \\
6 \\
-\end{array}$ & $\cdot$ & $\begin{array}{l}5 \\
- \\
1 \\
1 \\
8 \\
7 \\
2\end{array}$ & & $\begin{array}{l}6 \\
2 \\
2 \\
3 \\
3 \\
5 \\
6 \\
1 \\
\end{array}$ & . & $\begin{array}{l}9 \\
- \\
2 \\
1 \\
1 \\
1 \\
2 \\
1\end{array}$ & , & $\begin{array}{r}37 \\
3 \\
5 \\
2 \\
21 \\
45 \\
27 \\
4\end{array}$ & . \\
\hline 7a. Reglão - Bauru & 6 & 8,70 & 7 & 10,14 & 16 & 23,19 & 33 & 47,83 & 7 & 10,14 & 69 & 4.27 \\
\hline $\begin{array}{l}\text { 1a. Sub- Bauru } \\
\text { 2a. Sub- L1ns } \\
\text { 3a. Sub- Jaú } \\
\end{array}$ & $\frac{3}{3}$ & & $\begin{array}{l}5 \\
1 \\
1 \\
\end{array}$ & & $\begin{array}{r}13 \\
2 \\
1 \\
\end{array}$ & & $\begin{array}{r}20 \\
9 \\
\end{array}$ & . & $\begin{array}{l}1 \\
2 \\
1\end{array}$ & & $\begin{array}{r}45 \\
9 \\
15 \\
\end{array}$ & \\
\hline 8a. Reglão - sāo Josê R. Preto & 9 & 24,32 & 6 & 16,22 & 8 & 21,62 & 7 & 18,92 & 7 & 18,92 & 37 & 2,29 \\
\hline $\begin{array}{l}\text { 1a. Sub- São José R. Preto } \\
\text { 2a. Sub- Catanduva } \\
\text { 3a. Sub- Votuporanga }\end{array}$ & $\begin{array}{l}6 \\
3 \\
-\end{array}$ & & 2 & & $\begin{array}{l}6 \\
2 \\
-\end{array}$ & & $\begin{array}{l}5 \\
2 \\
-\end{array}$ & & $\overline{6}$ & & $\begin{array}{r}19 \\
17 \\
1\end{array}$ & \\
\hline 9a. Reg1āo - Araçatuba & 2 & 8,33 & 1 & 4,17 & 7 & 29,17 & 10 & 41,66 & 4 & 16,67 & 24 & 1.40 \\
\hline $\begin{array}{l}\text { 1a. Sub- Aracatuba } \\
\text { 2a. Sub- Andradina }\end{array}$ & 2 & & 2 & & $\begin{array}{l}6 \\
1\end{array}$ & & $\stackrel{9}{1}$ & & $\begin{array}{l}2 \\
2 \\
\end{array}$ & & $\begin{array}{r}20 \\
4\end{array}$ & \\
\hline Oa. Reqlão - Preslente Prudente & 1 & 1,89 & 13 & 6,13 & 49 & 23,11 & 115 & 54,25 & 31 & 14,62 & 212 & $\$ 3,12$ \\
\hline $\begin{array}{l}\text { la. Sub- Presidente Prudente } \\
\text { 2a. Sub- Presidente Venceslau } \\
\text { 3a. Sub- Dracena } \\
\text { 1a. Sub- Adamantina } \\
\text { 5a. Sub- Osvaldo Cruz }\end{array}$ & \pm & & 13 & & $\begin{array}{r}13 \\
3 \\
-3 \\
-\end{array}$ & & $\begin{array}{r}90 \\
12 \\
5 \\
6 \\
2 \\
\end{array}$ & & $\frac{24}{1}$ & & $\begin{array}{r}174 \\
16 \\
5 \\
15 \\
2 \\
\end{array}$ & . \\
\hline Ila. Reglāo - Marilla & 47 & 5,88 & 58 & 7.26 & 221 & $27,3.6$ & 299 & 37.42 & 174 & 21.78 & 799 & $.42,49$ \\
\hline $\begin{array}{l}\text { 2a. Sub- Marfila } \\
\text { 2a. Sub- Assis } \\
\text { 3a. Sub- Ourinhos } \\
\text { 4a. Sub-Tupã }\end{array}$ & $\begin{array}{l}24 \\
23 \\
-\end{array}$ & & $\begin{array}{r}3 \\
10 \\
12 \\
4\end{array}$ & & $\begin{array}{r}22 \\
253 \\
37 \\
9\end{array}$ & & $\begin{array}{r}52 \\
209 \\
31 \\
7\end{array}$ & & $\begin{array}{r}16 \\
232 \\
24 \\
2\end{array}$ & & $\begin{array}{r}93 \\
558 \\
126 \\
22\end{array}$ & \\
\hline$T \cdot 0 \quad z \quad A \quad I \quad s$ & 153 & 9,47 & 173 & 10,70 & 387 & 23,25 & 606 & 37,50 & 297 & 18,38 & .616 & 100,00 \\
\hline Rural de Paraguaçu Paulista & 22 & 5,35 & 23 & 5,60 & 82 & 19,95 & 193 & 46,96 & 91 & 22,14 & 411 & 100,00 \\
\hline
\end{tabular}

corre: Levantamento realizado en tina do 1971 e iniclo do 1972. 
Provenióncia da populaçäo Paulista, 11xada om Paraquagu Paulista, por looal de

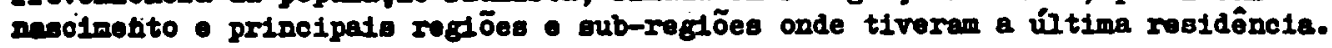

Tabola 22

\begin{tabular}{|c|c|c|c|c|c|c|c|c|c|c|}
\hline \multicolumn{3}{|c|}{ Iocal do nescimento } & \multicolumn{8}{|c|}{ UI I I M $\triangle$ RESIDE ICI } \\
\hline \multirow[b]{2}{*}{ (Dog. Ldintinis trat } & \multicolumn{2}{|c|}{$2091 I$} & \multirow{2}{*}{ Bogtão } & \multirow{2}{*}{$\begin{array}{l}\text { Abeol. } \\
\text { (rog. of } \\
\text { matox in } \\
\text { oldion in }\end{array}$} & \multicolumn{2}{|c|}{$\begin{array}{l}\text { fo an relagâo } \\
\text { an } 200 \text {. Haco. }\end{array}$} & \multirow{2}{*}{ Sub-Região } & \multirow{2}{*}{ 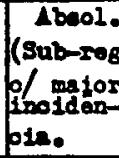 } & \multicolumn{2}{|c|}{ 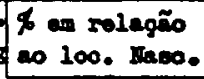 } \\
\hline & Abeol. & 8 & & & Regiño & $\begin{array}{l}\text { Total } \\
\text { Gera] }\end{array}$ & & & Regiñ & $\begin{array}{l}\text { Total } \\
\text { Geral }\end{array}$ \\
\hline Crande São Paulo & 69 & 4,27 & $\begin{array}{l}\text { G.S. Paulo } \\
\text { Marflia } \\
\text { Pres . Prudent }\end{array}$ & $\begin{array}{l}39 \\
21\end{array}$ & $\begin{array}{r}56,52 \\
15,94 \\
4,35 \\
\end{array}$ & $\begin{array}{l}2,41 \\
0,68 \\
0,19 \\
\end{array}$ & $\begin{array}{l}\text { Asels } \\
\text { Rur. P. Pta } \\
\text { P.Prudente }\end{array}$ & $\begin{array}{l}7 \\
4 \\
3 \\
\end{array}$ & $\begin{array}{r}10,14 \\
5,80 \\
4,35 \\
\end{array}$ & $\begin{array}{l}0,43 \\
0,25 \\
0,19 \\
\end{array}$ \\
\hline Iftoral & 5 & 0,32 & marilie & 3 & 80,00 & 0,25 & $\begin{array}{l}\text { Assis } \\
\text { Rur. P.Pta. }\end{array}$ & $\begin{array}{l}3 \\
1\end{array}$ & $\begin{array}{l}60,00 \\
20,00\end{array}$ & $\begin{array}{l}0,19 \\
0,06\end{array}$ \\
\hline Vale do Paraiba & 29 & 2,28 & $\begin{array}{l}\text { Vale Paraib } \\
\text { Marilia } \\
\text { P.Prudente } \\
\end{array}$ & $\begin{array}{l}3 \\
8\end{array}$ & $\begin{array}{r}21,05 \\
48,10 \\
5,26 \\
\end{array}$ & $\begin{array}{l}0,19 \\
0,50 \\
0,06\end{array}$ & $\begin{array}{l}\text { Gusrating. } \\
\text { Assis } \\
\text { Rur. P.Pta. } \\
\text { P.Prulente }\end{array}$ & $\begin{array}{l}3 \\
6 \\
1 \\
1 \\
\end{array}$ & $\begin{array}{r}21,05 \\
31,58 \\
5,26 \\
5,26 \\
\end{array}$ & $\begin{array}{l}0,19 \\
0,37 \\
0,06 \\
0,06 \\
\end{array}$ \\
\hline Sorocaba & 134 & 8,29 & $\begin{array}{l}\text { Sorocaba } \\
\text { marilia } \\
\text { P.Prudente } \\
\end{array}$ & $\begin{array}{l}56 \\
47\end{array}$ & $\begin{array}{r}41,79 \\
35,07 \\
6,72 \\
\end{array}$ & $\begin{array}{l}3,47 \\
2,91 \\
0,56\end{array}$ & $\begin{array}{l}\text { Avaré } \\
\text { Assia } \\
\text { Rur. P.Pta. } \\
\text { P.Prudente }\end{array}$ & $\begin{array}{r}39 \\
29 \\
21 \\
8 \\
\end{array}$ & $\begin{array}{r}21,10 \\
21,64 \\
8,21 \\
5,97 \\
\end{array}$ & $\begin{array}{l}2,41 \\
1,79 \\
0,68 \\
0,50 \\
\end{array}$ \\
\hline Campinas & 212 & 6,93 & $\begin{array}{l}\text { Campinas } \\
\text { Marilia } \\
\text { P.Prudente } \\
\end{array}$ & $\begin{array}{l}25 \\
43 \\
12 \\
\end{array}$ & $\begin{array}{l}22,32 \\
38,39 \\
10,71 \\
\end{array}$ & $\begin{array}{l}1,55 \\
2,66 \\
0,74\end{array}$ & $\begin{array}{l}\text { Piracicaba } \\
\text { Agsio } \\
\text { Rur. P.Pta } \\
\text { P.Prudente }\end{array}$ & $\begin{array}{r}6 \\
24 \\
25 \\
8 \\
\end{array}$ & $\begin{array}{r}5,36 \\
21,43 \\
13,39 \\
7,15 \\
\end{array}$ & $\begin{array}{l}0,37 \\
1,48 \\
0,93 \\
0,50 \\
\end{array}$ \\
\hline Bdbelrão Preto & 236 & 8,42 & $\begin{array}{l}\text { Rib. Prëto } \\
\mu_{Q} \text { rilia } \\
\text { P.Prudente }\end{array}$ & $\begin{array}{l}43 \\
46 \\
8 \\
\end{array}$ & $\begin{array}{r}32,62 \\
33,82 \\
5,88 \\
\end{array}$ & $\begin{array}{c}2,66 \\
2,85 \\
0,50\end{array}$ & $\begin{array}{l}\text { Jaboticabal } \\
\text { Assis } \\
\text { Mur. P.Pta. } \\
\text { P.Prudente }\end{array}$ & $\begin{array}{r}20 \\
21 \\
18 \\
6 \\
\end{array}$ & \begin{tabular}{|r|}
14,71 \\
15,44 \\
13,24 \\
4,41 \\
\end{tabular} & $\begin{array}{l}1,24 \\
1,30 \\
1,11 \\
0,37 \\
\end{array}$ \\
\hline $\sin$ & Ề & 4,27 & $\begin{array}{l}\text { Tanen } \\
\text { Parilia } \\
\text { P.Prudente }\end{array}$ & $\begin{array}{r}22 \\
30 \\
6\end{array}$ & $\begin{array}{r}j \bar{i}, \hat{0} \\
43,48 \\
8,69\end{array}$ & $\begin{array}{l}1,30 \\
1,87 \\
0,37\end{array}$ & $\begin{array}{l}\text { Oauru } \\
\text { Assia } \\
\text { Rur. P.Pta. } \\
\text { P.Prudente }\end{array}$ & $\begin{array}{r}14 \\
17 \\
3 \\
5 \\
\end{array}$ & $\left|\begin{array}{r}2 u, c y \\
24,64 \\
4,35 \\
7,25\end{array}\right|$ & $\begin{array}{l}0,01 \\
1,05 \\
0,19 \\
0,31\end{array}$ \\
\hline 8. José Rdo Prêto & 37 & 2,29 & $\begin{array}{l}\text { S.J.R.Prëto } \\
\text { Marilis } \\
\text { P.Prudente }\end{array}$ & $\begin{array}{l}13 \\
12 \\
3\end{array}$ & $\begin{array}{r}35,14 \\
29,73 \\
8,21 \\
\end{array}$ & $\begin{array}{l}0,80 \\
0,68 \\
0,29\end{array}$ & $\begin{array}{l}\text { S.J.R.Prëto } \\
\text { Assis } \\
\text { Rur. P.Pta. } \\
\text { P.Prudente }\end{array}$ & $\begin{array}{l}7 \\
7 \\
2 \\
3\end{array}$ & \begin{tabular}{|r|}
16,92 \\
18,92 \\
2,70 \\
8,11 \\
\end{tabular} & $\begin{array}{l}0,43 \\
0,43 \\
0,06 \\
0,19\end{array}$ \\
\hline Araçatuba & 24 & 1,48 & $\begin{array}{l}\text { Araçatuba } \\
\text { Marilia } \\
\text { P.Prudente }\end{array}$ & $\begin{array}{l}9 \\
6 \\
2\end{array}$ & $\begin{array}{r}37,50 \\
25,00 \\
8,33 \\
\end{array}$ & $\begin{array}{l}0,56 \\
0,37 \\
0,12\end{array}$ & $\begin{array}{l}\text { Araçatuba } \\
\text { Assis } \\
\text { Rur. P.Pta } \\
\text { P.Prudente }\end{array}$ & $\begin{array}{l}9 \\
4 \\
1 \\
2 \\
\end{array}$ & \begin{tabular}{|r|}
37,50 \\
16,67 \\
4,17 \\
8,33 \\
\end{tabular} & $\begin{array}{l}0,56 \\
0,25 \\
0,06 \\
0,12 \\
\end{array}$ \\
\hline Prosidente Pto. & 212 & 13,22 & $\begin{array}{l}\text { Prudente } \\
\text { Parilla }\end{array}$ & $\begin{array}{r}138 \\
34\end{array}$ & $\begin{array}{l}65,09 \\
26,04\end{array}$ & $\begin{array}{l}8,54 \\
2,20 \\
\end{array}$ & $\begin{array}{l}\text { P.Prudente } \\
\text { Assis } \\
\text { Fur. P.Pta. }\end{array}$ & $\begin{array}{r}215 \\
23 \\
6 \\
\end{array}$ & \begin{tabular}{|r|}
54,24 \\
10,85 \\
2,83 \\
\end{tabular} & $\begin{array}{l}7,12 \\
1,42 \\
0,37 \\
\end{array}$ \\
\hline Marilia & 799 & 49,44 & $\begin{array}{l}\text { Mrilia } \\
\text { P.Prudente } \\
\text { g.S. Paulo }\end{array}$ & $\begin{array}{r}40 \\
22 \\
\end{array}$ & $\begin{array}{l}73,97 \\
5,02 \\
2,75 \\
\end{array}$ & $\begin{array}{l}36,57 \\
2,47 \\
1,36\end{array}$ & $\begin{array}{l}\text { Riarilia } \\
\text { Assis } \\
\text { Rur. P.Pta } \\
\text { P.Prudente } \\
\end{array}$ & $\begin{array}{r}74 \\
400 \\
52 \\
31 \\
\end{array}$ & $\mid \begin{array}{r}9,26 \\
50,06 \\
6,51 \\
3,88 \\
\end{array}$ & $\begin{array}{r}4,58 \\
24,75 \\
3,22 \\
1,92 \\
\end{array}$ \\
\hline Total Geral & 1.616 & 100,00 & $\begin{array}{l}\text { parilia } \\
\text { piprudente }\end{array}$ & $\begin{array}{l}831 \\
212\end{array}$ & & & $\begin{array}{l}\text { Asaio } \\
\text { Rux. P.Pta } \\
\text { P.Prudente }\end{array}$ & $\begin{array}{l}541 \\
113 \\
182\end{array}$ & & $\begin{array}{r}33,48 \\
6,99 \\
27,26\end{array}$ \\
\hline
\end{tabular}

rantes Lovantamento diroto, realizado om aproximadamento 1.000 rmidências $-1971 / 72$.

Eromplo axplioativo para a tabela Do total de 1.616 paulistas que so firam om Paracualu, 69 nacooram na -

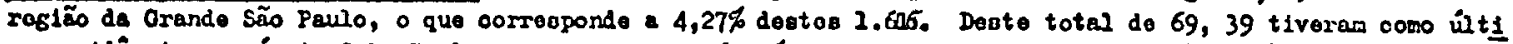

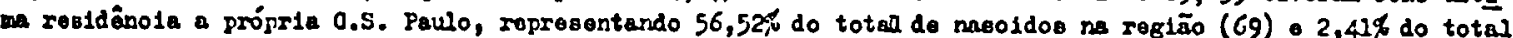

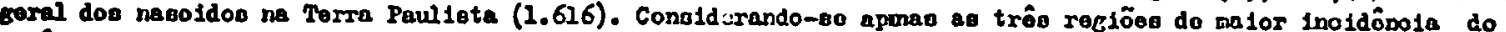

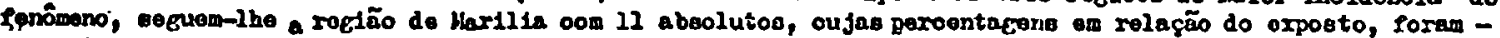

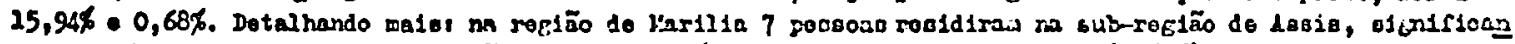
do 10,148 dos nanoidos na Grande são Parlo $0,43 \%$ dos pauliotas da amostrapen (1.616). 
Proventincia da populaçäo nacional não paulista e estrangeira, ltxada em Paraguaçu Peullsta, por local de nascimento o princlpála áreas, regiöes • sub-regiöes onde tivoram sua úl tima residencia.

Tabola 23

\begin{tabular}{|c|c|c|c|c|c|c|c|c|c|c|}
\hline \multicolumn{3}{|c|}{ Iooal do nascimento } & \multicolumn{8}{|c|}{ OITIMA BESIDENCIA } \\
\hline \multirow[b]{2}{*}{$\begin{array}{l}\text { (Estado, Pegião } \\
\text { ou Pafa) }\end{array}$} & \multicolumn{2}{|c|}{ IOT I I } & \multirow{2}{*}{$\begin{array}{l}\text { Eatado, Paf́ } \\
\text { ou regtāo } \\
\text { adminiatrat }\end{array}$} & \multirow{2}{*}{$\begin{array}{l}\text { Absolut } \\
\text { (irgas of } \\
\text { malor th } \\
\text { cidêno in }\end{array}$} & \multicolumn{2}{|c|}{$\begin{array}{l}6 \text { om rolagão } \\
\text { oo } 100 \text {. Naso. }\end{array}$} & \multirow{2}{*}{$\begin{array}{l}\text { Sub-região } \\
\text { Administrat }\end{array}$} & \multirow{2}{*}{ 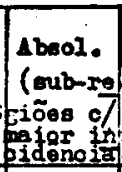 } & \multicolumn{2}{|c|}{ 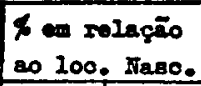 } \\
\hline & & & & & $\begin{array}{l}\text { Sstado } \\
\text { Pals } \\
\text { Regiã } \\
\end{array}$ & $\begin{array}{l}\text { Total } \\
\text { Gera] } \\
\end{array}$ & & & 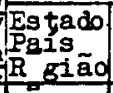 & $\begin{array}{l}\text { Total } \\
\text { Geral } \\
\end{array}$ \\
\hline yinae Gerala & 187 & 32,24 & $\begin{array}{l}\text { Minas Geraia } \\
\text { Milarilia } \\
\text { P. Prudente }\end{array}$ & $\begin{array}{l}48 \\
77 \\
17 \\
\end{array}$ & $\begin{array}{r}25,67 \\
41,18 \\
9,09 \\
\end{array}$ & $\begin{array}{r}8,28 \\
33,28 \\
2,93 \\
\end{array}$ & $\begin{array}{l}\text { Assis } \\
\text { Pur. P.Pta } \\
\text { P.Prudente }\end{array}$ & $\begin{array}{l}29 \\
35 \\
12\end{array}$ & $\begin{array}{r}15,51 \\
18,72 \\
6,42\end{array}$ & $\begin{array}{l}5,00 \\
6,03 \\
2,07\end{array}$ \\
\hline Paraná & 104 & 27,93 & $\begin{array}{l}\text { Paraná } \\
\text { Marília } \\
\text { P.Prudente }\end{array}$ & $\begin{array}{r}27 \\
32 \\
5 \\
\end{array}$ & $\begin{array}{r}25,96 \\
30,77 \\
4,81 \\
\end{array}$ & $\begin{array}{l}4,66 \\
5,52 \\
0,86 \\
\end{array}$ & $\begin{array}{l}\text { Assis } \\
\text { Bur.P.Pta. } \\
\text { P.Prudente }\end{array}$ & $\begin{array}{r}25 \\
6 \\
5 \\
\end{array}$ & $\begin{array}{r}24,04 \\
5,77 \\
4,81 \\
\end{array}$ & $\begin{array}{l}4,31 \\
1,03 \\
0,86 \\
\end{array}$ \\
\hline Bahia & 109 & 18,79 & \begin{tabular}{|l} 
Bahia \\
Marilia \\
P.Prudente \\
\end{tabular} & $\begin{array}{r}27 \\
54 \\
7 \\
\end{array}$ & $\begin{array}{r}24,77 \\
49,54 \\
\\
6,42 \\
\end{array}$ & $\begin{array}{l}4,66 \\
9,31 \\
1,21 \\
\end{array}$ & $\begin{array}{l}\text { Assis } \\
\text { Rur.P.Pta. } \\
\text { P.Prudente } \\
\end{array}$ & $\begin{array}{r}22 \\
29 \\
6 \\
\end{array}$ & $\begin{array}{r}20,28 \\
26,61 \\
5,50 \\
\end{array}$ & $\begin{array}{l}3,79 \\
5,00 \\
1,03 \\
\end{array}$ \\
\hline $\begin{array}{l}\text { Fordeste (exce- } \\
\text { to Bahia) }\end{array}$ & 138 & 23,79 & $\begin{array}{l}\text { Nordeate } \\
\text { Marilia } \\
\text { P.Prudente } \\
\end{array}$ & $\begin{array}{l}27 \\
54 \\
16 \\
\end{array}$ & $\begin{array}{r}19,59 \\
39,23 \\
17,59 \\
\end{array}$ & $\begin{array}{l}4,66 \\
9,31 \\
2,76 \\
\end{array}$ & $\begin{array}{l}\text { Assis } \\
\text { Bur.P.Pta. } \\
\text { P.Prudente }\end{array}$ & $\begin{array}{l}29 \\
19 \\
11\end{array}$ & $\begin{array}{r}21,01 \\
13,77 \\
7,97\end{array}$ & $\begin{array}{l}5,00 \\
3,28 \\
1,90 \\
\end{array}$ \\
\hline $\begin{array}{l}\text { Demalo Estados do } \\
\text { Sul, SE, CO, Nor, } \\
\text { te (excoto Parané }\end{array}$ & 42 & 7,24 & $\begin{array}{l}\text { Mato Grosso } \\
\text { Marilia } \\
\text { P.Prudente }\end{array}$ & $\begin{array}{r}7 \\
21 \\
5 \\
\end{array}$ & $\begin{array}{l}16,67 \\
26,19 \\
11,90\end{array}$ & $\begin{array}{l}1,21 \\
1,90 \\
0,86\end{array}$ & $\begin{array}{l}\text { Assis } \\
\text { Rur.P.Pta. } \\
\text { P.Prudente } \\
\end{array}$ & $\begin{array}{l}9 \\
2 \\
5 \\
\end{array}$ & $\begin{array}{r}21,43 \\
2,38 \\
11,90 \\
\end{array}$ & $\begin{array}{l}1,55 \\
0,17 \\
0,86 \\
\end{array}$ \\
\hline rama? & $58 n$ & 200.20 & $\begin{array}{l}\text { Mn-1?da } \\
\text { D.Prudente }\end{array}$ & $\begin{array}{r}228 \\
50 \\
\end{array}$ & & 8,62 & $\begin{array}{l}\text { As } \\
\text { Rur.P.Pts. Pts. } \\
\text { P.Prudente }\end{array}$ & $\begin{array}{r}2 i 2 \\
90 \\
39 \\
\end{array}$ & & $\begin{array}{r}15.45 \\
15,52 \\
6,72 \\
\end{array}$ \\
\hline
\end{tabular}

POPULAGTO ESTRANGEIRA

\begin{tabular}{|c|c|c|c|c|c|c|c|c|c|c|}
\hline Portugal & 27 & 25,23 & $\begin{array}{l}\text { Portugal } \\
\text { Marilia } \\
\text { P.Prudente }\end{array}$ & $\begin{array}{r}3 \\
6 \\
5 \\
\end{array}$ & $\begin{array}{l}11,11 \\
22,22 \\
18,52 \\
\end{array}$ & $\begin{array}{l}2,80 \\
5,67 \\
4,67 \\
\end{array}$ & $\begin{array}{l}\text { Asais } \\
\text { Rur.P.Pta. } \\
\text { P.Prudente }\end{array}$ & $\begin{array}{l}4 \\
2 \\
3 \\
\end{array}$ & $\begin{array}{r}14,81 \\
7,41 \\
21,12 \\
\end{array}$ & $\begin{array}{l}3,74 \\
1,87 \\
2,80 \\
\end{array}$ \\
\hline Japão & 27 & 25,23 & $\begin{array}{l}\text { Marília } \\
\text { P..Prudente }\end{array}$ & $\begin{array}{r}18 \\
1 \\
\end{array}$ & $\begin{array}{r}66,67 \\
3,70 \\
\end{array}$ & $\begin{array}{l}6,82 \\
0,93\end{array}$ & $\begin{array}{l}\text { Assis } \\
\text { Rur. P.Pta } \\
\text { P.Prudente }\end{array}$ & $\begin{array}{r}4 \\
10 \\
1\end{array}$ & \begin{tabular}{|r|}
14,81 \\
37,04 \\
3,70
\end{tabular} & $\begin{array}{l}3,74 \\
9,35 \\
0,93\end{array}$ \\
\hline Espanha & 16 & 14,95 & $\begin{array}{l}\text { Marilina } \\
\text { P.Prudente }\end{array}$ & $\begin{array}{l}6 \\
2\end{array}$ & $\begin{array}{l}37,50 \\
12,50\end{array}$ & $\begin{array}{l}5,61 \\
1,87\end{array}$ & \begin{tabular}{l|} 
Marília \\
Rux.P.Pta. \\
P.Prudente
\end{tabular} & $\begin{array}{l}4 \\
2 \\
2\end{array}$ & $\begin{array}{r}25,00 \\
6,25 \\
12,50\end{array}$ & $\begin{array}{l}3,74 \\
0,93 \\
3,87\end{array}$ \\
\hline If́ano & 16 & 14,95 & $\begin{array}{l}\text { If bano } \\
\text { Marília }\end{array}$ & $\frac{11}{2}$ & $\begin{array}{l}68,75 \\
12,50 \\
\end{array}$ & 1,87 & Assis & 2 & 22,50 & 1,87 \\
\hline Italia & 23 & 12,15 & Marflia & 5 & 38,46 & 4,67 & Asaia & 5 & 38,46 & $\overline{4,67}$ \\
\hline Outros Países & 8 & 7,48 & Marflia & 3 & 37,50 & 2,80 & $\begin{array}{l}\text { Assis } \\
\text { Rur.P.Pta. } \\
\end{array}$ & $\begin{array}{l}1 \\
2 \\
\end{array}$ & $\begin{array}{l}12,50 \\
25,00 \\
\end{array}$ & $\begin{array}{l}0,93 \\
1,87 \\
\end{array}$ \\
\hline rotal Geral & 207 & 100,00 & $\begin{array}{l}\text { Marfilia } \\
\text { P.Prudente }\end{array}$ & $\begin{array}{r}40 \\
8\end{array}$ & $:$ & $\begin{array}{l}37,38 \\
7,48\end{array}$ & $\begin{array}{l}\text { Asais } \\
\text { Rur. P.Pta } \\
\text { P.Prudente }\end{array}$ & $\begin{array}{r}17 \\
15 \\
6\end{array}$ & & $\begin{array}{r}15,89 \\
14,02 \\
5,61\end{array}$ \\
\hline
\end{tabular}

Ponte: Lovantamento direto, realizado em aproxtmadamente 3.000 residëncias $-1972 / 72$

Obs. \& nota explicativa referento à tabela

aplica-be a eata. 


\section{Iistas.' (Tabela 23)}

Consideradas estas procedências ao nível de sub-Regiões, verifica-se que a vigorosidade do movimento se faz em direção áquela de Assis, da qual Paraguaçu Paulista é integrante, à zo na rural de Paraguaçu ou àquela de Presidente Prudente.

Assim, no tocante aos paulistas, 33,488 escolhem a subregião de Assis como etapa que antecede a sua fixação na cidade de Paraguaçu Paulista; 11,268 escolhem a sub-região de Presiden te Prudente e 6,998 a zona rural do municipio. (Tabela 23)

Para os demais brasileiros a preferência é a mesma dos paulistas alterando-se apenas a ordem, pois estes são mais sig niflcativos na sub-regtão de Assis, zona rural de Paraguaçu Pau lista e sub-região de Presidente Prudente. Finalmente, os es trangeiros definem o seu movimento da mesma forma que o grupo anterior. (Tabela 23)

Além destas considerações sobre a provenfência espacial, há que se considerar a proveniência no tempo, que será vista em quatro períodos: até 1940, de 1941 a 1950 , de 1951 a $19^{\circ} 60$ e de 1961 a 1972.

Verifica-se no conjunto que o periodo mals expressivo é

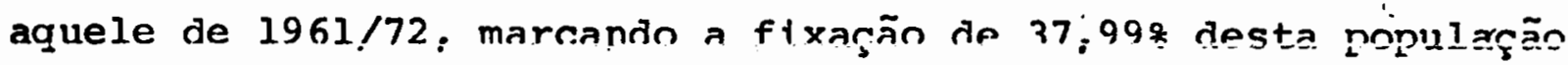
decrescendo à medida que se distancia no tempo, alcançando a sua menor particlpação ou fixação no período anterior a 1940', com 10,388. Esta proventêncla no tempo repete aquela espacial quanto à contribuição de cada grupo: a maior participação cabe aos paulistas seguida dos demais nacionals e por último os es trangelros. Deve-se apenas ressalvar que estes ūltimos apresen tam variações na participação, sendo o período mais próximo o que tem a menor percentagem. (Tabela 24)

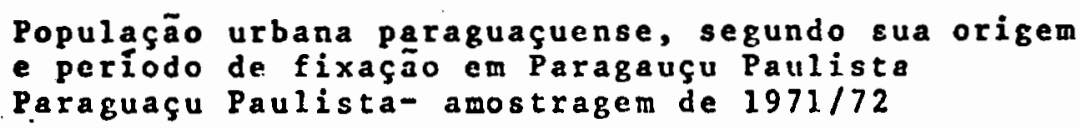

Tabela 24

\begin{tabular}{|c|c|c|c|c|c|c|c|c|c|c|}
\hline & \multicolumn{2}{|c|}{ Ant. 1940} & \multicolumn{2}{|c|}{$1941 / 50$} & \multicolumn{2}{|c|}{$1951 / 60$} & \multicolumn{2}{|c|}{$1961 / 72$} & \multicolumn{2}{|c|}{$\begin{array}{l}\text { sem defini- } \\
\text { ẫo de daten }\end{array}$} \\
\hline & abs & 8 & labs & 8 & abs & 3 & abs & 8 & abs & 8 \\
\hline Paul1stas & 153 & 6,65 & 173 & 7,51 & 387 & 16.80 & 606 & 26,31 & 297 & 12,90 \\
\hline Não Paulistas & 59 & 2,56 & 55 & 2,39 & 133 & 5,78 & 253 & 10,99 & 80 & 3,47 \\
\hline Estrangelros & 27 & 1,17 & 23 & 1,00 & 30 & 1.30 & 16 & 0,69 & 11 & 0,48 \\
\hline T O T A L & 239 & 10,38 & 251 & 10,90 & 550 & 23,88 & 875 & 37,99 & 388 & 16,85 \\
\hline
\end{tabular}


Caracterizando-se esta condição temporal, em cada grupo, define-se certa constância para os paulistas nascidos nas re giões de Sorocaba, Campinas, Ribeirão Preto. As regiões de Pre sidente Prudente e Marília também contribuem, havendo um acele ramento ou vigorosidade no processo a partir de 1951, sendo mar cante no último periodo.

Para os demais nacionais este aceleramento do processo é observado a partir de 1951, principalmente para nordestinos e paranaenses, ressalvando-se apenas a participação mineira que apresenta um aumento relativamente constante a cada período, con forme pode-se notar na Tabela abaixo.

População Estadual que se fixa em Paraguaçu Paulista, com a região de proventência segundo o local de nascí mento e período de fixação.

Paraguaçu Paulista - Amostrạgem - 1971/72

Tabela 25

\begin{tabular}{|c|c|c|c|c|c|c|c|c|c|c|}
\hline & \multicolumn{2}{|c|}{ Ant. 1940} & \multicolumn{2}{|c|}{$1911 / 50$} & \multicolumn{2}{|c|}{$1951 / 60$} & \multicolumn{2}{|c|}{$1961 / 72$} & \multicolumn{2}{|c|}{$\begin{array}{l}\text { sen defin } \\
\text { icao de }\end{array}$} \\
\hline & abs & 8 & abs & $q$ & abs & 8 & abs & 8 & labs & $\varepsilon$ \\
\hline Grande S.Paulo & 3 & 0,18 & 6 & 0,37 & 11 & 0,68 & 29 & 1,79 & 20 & 1,24 \\
\hline Iftoral & 1 & 0,06 & 1 & 0,06 & 1 & 0,06 & - & - & 2 & 0,13 \\
\hline Vale-Paraíba & 1 & 0,06 & 4 & 0,25 & 4 & 0,25 & 9 & 0,56 & 1 & 0,06 \\
\hline Sorocaba & 17 & 1,05 & 29 & 1,79 & 23 & 1,42 & 46 & 2,85 & 19 & 1,18 \\
\hline Campinas & 23 & 1,42 & 22 & 1,36 & 23 & 1,42 & 32 & 1,98 & 12 & 0,71 \\
\hline Rib. Preto & 40 & 2,48 & 26 & 1,61 & 24 & 1,49 & 26 & 1,61 & 20 & 1,24 \\
\hline Baurı & 6 & 0,37 & 7 & 0,43 & 16 & 0.99 & 33 & 2.04 & 7 & 0.43 \\
\hline S.J.Rio Preto & 9 & 0,56 & 6 & 0,37 & 8 & 0,49 & 7 & 0,43 & 7 & 0,43 \\
\hline Araçatuba & 2 & 0,12 & 1 & 0,06 & 7 & 0,43 & 10 & 0,62 & 4 & 0,25 \\
\hline P. Prudente & 4 & 0,25 & 13 & 0,80 & 49 & 3,03 & 115 & 7,12 & 31 & 1,92 \\
\hline Marilia & 47 & 2,91 & 58 & 3,59 & 222 & 13,68 & 299 & 18.50 & 1.74 & 10,77 \\
\hline TOTAL & 153 & 9,47 . & 173 & 10,70 & 387 & 23,95 & 606 & 37,50 & 297 & 18,38 \\
\hline
\end{tabular}

Total Geral $1.616=100,008$

Outros Estados:

\begin{tabular}{|l|r|r|r|r|r|r|r|r|r|r|}
\hline Mrras Cerais & 23 & 3,96 & 33 & 5,69 & 46 & 7,93 & 53 & 10,00 & 27 & 4,65 \\
Paraná & 1 & 0,17 & 3 & 0,52 & 10 & 1,72 & 65 & 11,21 & 25 & 4,31 \\
Nordeste & 26 & 4,48 & 17 & 2,93 & 65 & 11,21 & 119 & 20,52 & 20 & 3,45 \\
Sul (-PR) & 3 & 0,52 & - & - & - & - & 2 & 0,34 & - & - \\
GB e RJ & 4 & 0,69 & 2 & 0,34 & 5 & 0,86 & 6 & 1,03 & 3 & 0,52 \\
Centro Ocste \\
e Norte
\end{tabular}


Os estrangeiros têm presença mais acentuada nos períodos entre 1951 e 1960, com maior importância aos japoneses e portú guêses, sendo que estes últimos, ao lado dos ltalianos, são os que se destacam no periodo anterior a 1940. (Tabela 26)

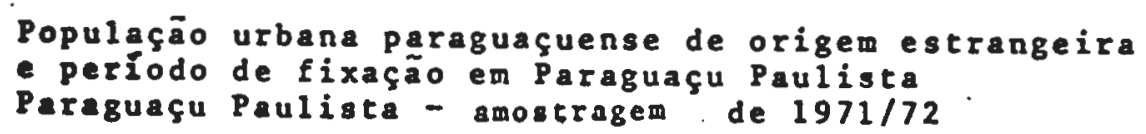

\begin{tabular}{|c|c|c|c|c|c|c|c|c|c|c|}
\hline & \multicolumn{2}{|c|}{ Ant. 1940} & \multicolumn{2}{|c|}{$1941 / 50$} & \multicolumn{2}{|c|}{$1951 / 60$} & \multicolumn{2}{|c|}{$1961 / 70$} & \multicolumn{2}{|c|}{$\begin{array}{l}\text { sem detini } \\
\text { caodedata }\end{array}$} \\
\hline & abs & 8 & abs & 8 & abs & 8 & abs & 8 & abs & 8 \\
\hline Japão & 3 & 2,80 & 9 & 8,41 & 8 & 7.48 & 3 & 2,80 & 4 & 3,74 \\
\hline Portugual & 9 & 8,41 & 5 & 4,67 & 9 & 8,41 & 3 & 2,80 & 1 & 0,93 \\
\hline Espanha & 5 & 4,67 & 4 & 3,74 & 2 & 1,87 & 3 & 2,80 & 2 & 1,87 \\
\hline LIbano & 1 & 0,93 & 2 & 1,87 & 7 & 6.54 & 5 & 4,67 & 1 & 0,93 \\
\hline Itālla & 7 & 6,54 & 2 & 1,87 & 1 & 0,93 & - & - & 3 & 2,80 \\
\hline Outros palses & 2 & 1,87 & 1 & 0,93 & 3 & 2,80 & 2 & 1,87 & - & - \\
\hline TOTAI & 27 & 25,23 & 23 & 21,49 & 30 & 28,03 & 16 & 14,95 & 11 & 10,28 \\
\hline
\end{tabular}

Portanto, a composição da população urbana quanto à sua proveniência no eśpaço e através do tempo, çonsțitui em Paragua çu Paulista mals um exempló de um fenômenn já analisado por di versos campos das ciências Humanas, que é o da migração ruralurbana, secundada por migração urbana-urbana, isto é, de cida des pequenas e médias para sub-polos e polos regionais, caracte rístico de nossa época.

Ainda neste sentido observa-se que as migrações vistas pa ra o núcleo em questão guardam as linhas do processo geral: são intensas e marcantes em instância regional - regiōes de Marília, sub-região de Assis, onde Paraguaçu se insere e região de Pres $\underline{1}$ lente Prudente - e acentuadas a partir da década de 1950. 


\subsection{Estrutura Profissional da População Urbana}

Ao analisar-se a estrutura profissional tomar-se-á como fonte os dados obtidos nos levantamentos diretos realizados em aproximadamente 35,58 da população urbana de Paraguaçu Paulista (segundo Censo de 1970), abrangendo 4.786 pessoas, realizados em fins de 1971, inicio de 1972.

Embora tenha-se confirmada a presença de pequena parcela de pessoas com menos de 14 anos exercendo alguma atividade (44), considerar-se-á apenas aqueles com idade igual e superior a es ta como potencialmente ativas, sendo a ldade limite os 70 anos.

Dentro deste critērio a população urbana apresenta para ambos os sexos 3.112 pessoas potencialmente ativas, onde o sexo masculino participa com 47,948 e o feminino com 52,06\%. Neste conjunto a população econômicamente ativa representa pouco mats que a metade, cabendo ao sexo masculino a expressiva participação, como demonstra o quadro que segue.

\begin{tabular}{|l|r|r|r|r|r|r|}
\hline & \multicolumn{2}{|c|}{ TOTAL } & \multicolumn{1}{c|}{ MASCULINO } & \multicolumn{2}{c|}{ FEMININO } \\
\hline Pop.potenclalmente ativa & 3.112 & 100,00 & 1.492 & 47,94 & 1.620 & 52,06 \\
Pop.economicamente ativa & 1.576 & 50,64 & 1.157 & 37,18 & 419 & 13,46 \\
Pop. nāo economic. ativa & 1.536 & 49,36 & 335 & 10,76 & 1.201 & 38,60 \\
\hline
\end{tabular}

Considerando-se a estrutura profissional desta população verifica-se o seguinte: o setor de malor concentração é o tercí ário de serviços, seguido, em ordem decrescente de participação, pelo primário, secundārio e terciário de comércio. Neste total dos economicamente ativos apenas 7,048 constitui a parcela dos não assalariados, cabendo aos comerciantes 4,448 , figurando lo go a seguir os proprietários rurais com $2,04 \%$, industriais com 0,448 e proprietārios de atividades do terciário de serviços cam 0,128

(44). Neste levantamento apurou-se a existência de 37 pessoas com menos de 14 anos exercendo alguma atividade, significando $0,77 \%$ do total da amostragem. Destes havia 19 mas culinos: 5 com 11 anos, $4 \operatorname{com} 12$ anos e 10 com 13 anos,pre dominando a ativiade de bóia-fria (8) e auxiliar de peque na indústria (6). As 18 do sexo feminino apresentaram $1 \frac{4}{4}$ delas como empregadas domésticas, 3 como bóia-fria e 1 co mo auxiliar de atividade comercial. 
Os não economicamente atıvos têm sua expressão nas atị vidades domésticas (prendas domēsticas), estudantil, figurando em terceiro plano aqueles que não definiram uma atividade na época dos levantamentos. Os demais têm mínima participação. (Tâ bela 27 , figura 4.

Estrutura Profissional da População, distribuída por sexo e setor de atividade.

Paraguaçu Paulista - Amostragem -1971/72

Tabela 27

\begin{tabular}{|c|c|c|c|c|c|c|}
\hline \multirow{2}{*}{ SETOR DE ATIVIDADE } & \multicolumn{2}{|c|}{ MASCULINO } & \multicolumn{2}{|c|}{ FEMININO } & \multicolumn{2}{|c|}{ TOTAL } \\
\hline & abs & 8 & abs & 8 & abs & 8 \\
\hline $\begin{array}{l}\text { Primārio } \\
\text { Secundärıo } \\
\text { Terciār.Comércio } \\
\text { Terciār.Serviços }\end{array}$ & $\begin{array}{l}257 \\
215 \\
185 \\
500\end{array}$ & $\begin{array}{l}17,22 \\
14,41 \\
12,40 \\
33,51\end{array}$ & $\begin{array}{r}19 \\
16 \\
26 \\
358\end{array}$ & $\begin{array}{r}1,17 \\
0,99 \\
1,60 \\
22,10\end{array}$ & $\begin{array}{l}276 \\
231 \\
211 \\
858\end{array}$ & $\begin{array}{r}8,87 \\
7,42 \\
6,78 \\
27,57\end{array}$ \\
\hline TOTAL & 1.157 & 77,54 & 419 & 25,86 & 1.576 & 50,64 \\
\hline $\begin{array}{l}\text { Estudantes } \\
\text { Prendas Domēsticas } \\
\text { Aposentados } \\
\text { Sem defintção } \\
\text { Doentes e Inválidos } \\
\text { Sem trabalho }\end{array}$ & $\begin{array}{r}139 \\
- \\
54 \\
91 \\
16 \\
35\end{array}$ & $\begin{array}{r}9,32 \\
- \\
3,62 \\
6,10 \\
1,07 \\
2,35\end{array}$ & $\begin{array}{r}189 \\
795 \\
- \\
207 \\
4 \\
6\end{array}$ & $\begin{array}{r}11,67 \\
49,07 \\
12,78 \\
0,25 \\
0,37\end{array}$ & $\begin{array}{r}328 \\
795 \\
54 \\
298 \\
20 \\
41\end{array}$ & $\begin{array}{r}10,54 \\
25,55 \\
1,74 \\
9,57 \\
0,64 \\
1,32\end{array}$ \\
\hline TOTAL & 335 & 22,46 & 1.201 & 74,14 & 1.536 & 49,36 \\
\hline TOTAL GERAL & 1.492 & 100,00 & 1.620 & 100,00 & 3.112 & 100,00 \\
\hline
\end{tabular}

FONTE: Levantamento $71 / 72$

Outro aspecto a ser considerado é aquele da origem desta população.

Tomada aquela em 1dade ativa, verifica-se que 17,588 tèm. origem rural e 82,428 são de origem urbana.

Verificando-se a estrutura profissional para uma e outra origem nota-se, com pequenas diferenças, que ambas guardam as mesmas proporções apresentadas no total, o que pode ser visto a través da Tabela 28.

Entretanto, esta população apresenta mudanças profissio nais e de setores de atıvidades. Neste sentido far-se-á uma com paração entre a estrutura declarada no momento do levantamento (fins de 1971 e início de 1972) e aquela declarada imediatamente 
POPULACÃo ECONOMICAMENTE ATIVA ASSALARIAda E PRJPRIETÁrIa

E POPULACATO ECONOMICAMENTE NĀO ATIVA

PQPULAGÃO MASGULIMA
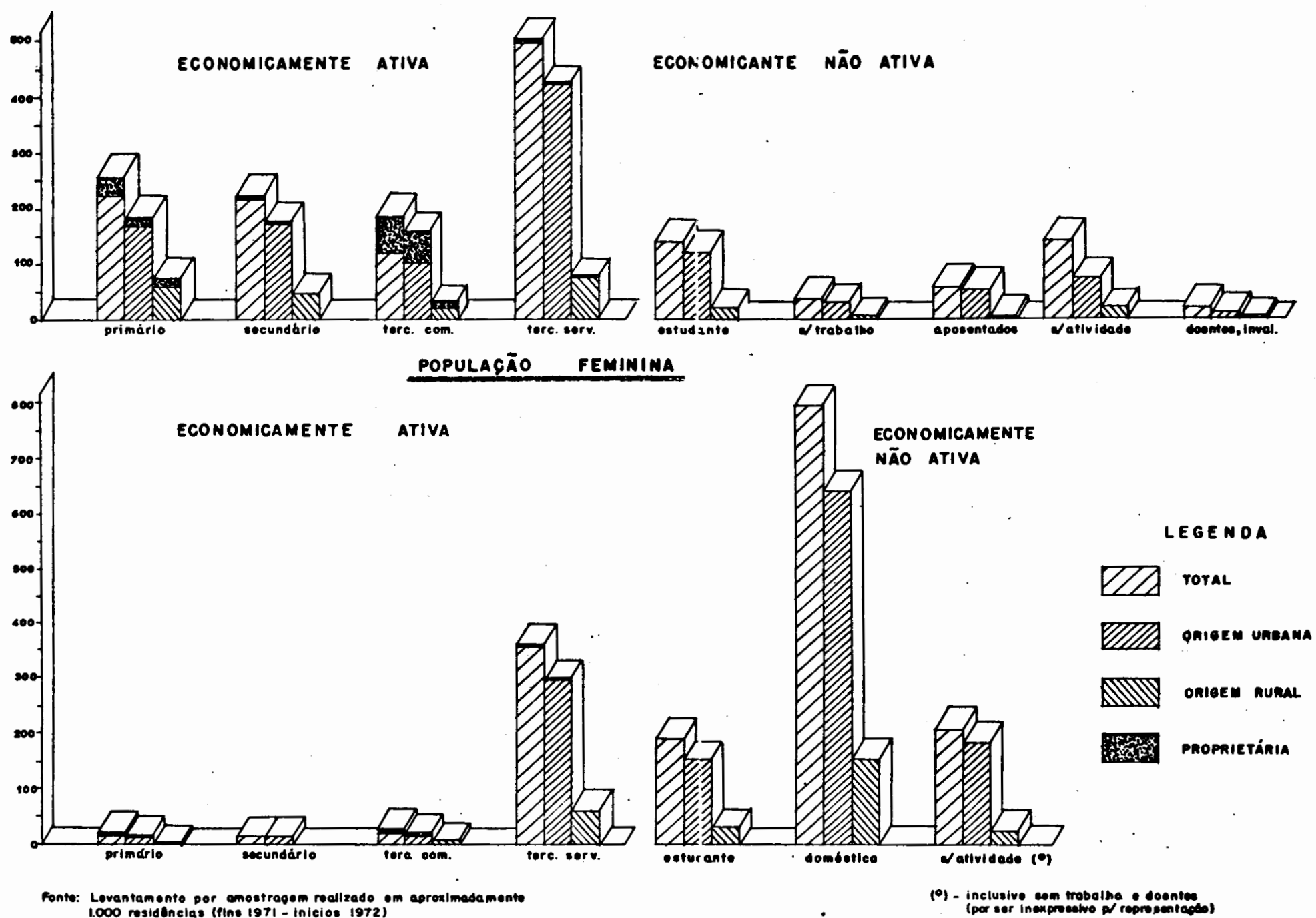
Estrutura profissional da população urbana, distribuida por sexo, setor de atividade e.origem (rural ou urbana)

Paraguaçu Paulista - amostragem 1971/72

Tabela 28

\begin{tabular}{|c|c|c|c|c|c|c|c|c|c|c|c|c|}
\hline \multirow{3}{*}{ SEROR DE ATIVIDADE } & \multicolumn{6}{|c|}{$0 R B A: 0$} & \multicolumn{6}{|c|}{ U1IRA A } \\
\hline & \multicolumn{2}{|c|}{ Msculino } & \multicolumn{2}{|c|}{ EL:UI:UI:0 } & \multicolumn{2}{|c|}{ TOT'A. } & \multicolumn{2}{|c|}{ MSCLLI:O } & \multicolumn{2}{|c|}{ FEYYIMIMO } & \multicolumn{2}{|c|}{ TSTRE } \\
\hline & $a b s$ & 1 & abs & 1 & abs & 1 & ahs & 1 & abs & 1 & abs & 1 \\
\hline Prlmár lo & 183 & 14,95 & 16 & 1,19 & 199 & $7, .76$ & 74 & 27,61 & 3 & $1,08$. & 77 & 14,08 \\
\hline Secundario & 172 & 14,05 & 16 & 1,19 & 188 & 7,33 & 13 & 16,04 & - & - & 43 & 7,86 \\
\hline Terc. Comärclo & 156 & 12,75 & 22 & 1,64 & 178 & 6,94 & 29 & 10,82 & $i$ & 1,43 & 33 & 6,03 \\
\hline Terc. Serviços & 425 & 34,72 & 298 & 22,22 & 723 & 28,19 & 75 & 27,98 & 60 & 21,51 & 135 & 24,68 \\
\hline TOTAL & 936 & 76,47 & 352 & 26,24 & 1.283 & 50.22 & 221 & 82,45 & 67 & 24,02 & 283 & 52,65 \\
\hline Estudantes & 121 & 9,89 & 157 & 11,71 & 278 & 10,84 & 18 & 6,72 & 32 & 11,47 & 50 & 9,14 \\
\hline Prend.Domëstlcas & - & - & 640 & 47.73 & 640 & 24,05 & - & - & 255 & 55,55 & 155 & 28,34 \\
\hline Aposentados & 52 & 4.25 & - & - & 52 & 2,03 & 2 & 0,75 & - & - & 2 & 0,36 \\
\hline Sem detinlq̧ão & 72 & 5,88 & 184 & 13,72 & 256 & 9,98 & 19 & 7.09 & 23 & 8,24 & 12 & 7,68 \\
\hline Doentes e Invălid. & 13 & 1,06 & 3 & 0,22 & 16 & 0,62 & 3 & 1,12 & 1 & 0,36 & 4 & 0,73 \\
\hline Som trabalho & $30^{\circ}$ & 2,45 & 5 & 0,37 & 35 & $i, 36$ & 5 & 1,67 & 1 & 0,36 & 6 & 1,10 \\
\hline TOTAL & 283 & 23,53 & 932 & 73,75 & 1.277 & 43,78 & 47 & 17,55 & 212 & 75,98 & 259 & 47,35 \\
\hline TOTAS GERAL & 1.224 & 100,00 & $1.3+1$ & 100,00 & 2.565 & 100.00 & 263 & 100.00 & 279 & 100,00 & 547 & 100,00 \\
\hline
\end{tabular}

antes. Em ambas as fases considerar-se-ã a profissão da popu laçao como já integrante do núcleo urbano, uma vez que não hou ve elementos para determinar, no caso de imigrantes, se ocorreu mudança profissional quando estes se instalaram na cidade.

Com base nestes dados, construiu-se a Tabela 29 , que se

gue.

Mudanças Profissionais, considerando-se a profissão

anterior e atual.

Paraguaçu Paulista - Amostragem - 1971/72

Tabela 29

\begin{tabular}{|c|c|c|c|c|c|c|c|c|c|c|c|c|c|c|c|c|c|c|c|c|c|c|}
\hline \multirow[t]{3}{*}{ AITIMTS } & \multirow{2}{*}{\multicolumn{2}{|c|}{$\frac{\Delta \text { ranior }}{10512}$}} & \multicolumn{20}{|c|}{$A I I V I D A D E$} \\
\hline & & & \multicolumn{2}{|c|}{ PRnLLRTO } & \multicolumn{2}{|c|}{ SECWH DLPJo } & \multicolumn{2}{|c|}{ TERC. COYERRCIO } & \multicolumn{2}{|c|}{ TENC.SennçO } & \multicolumn{2}{|c|}{ EITUDATES } & \multicolumn{2}{|c|}{ P.DORG'STICAS } & \multicolumn{2}{|c|}{ S/DERDSIÇRO } & \multicolumn{2}{|c|}{ IPOSERITLOD } & \multicolumn{2}{|c|}{ 3/trasciso } & \multicolumn{2}{|c|}{ Dow1 } \\
\hline & abs. & 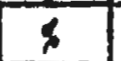 & aba. & 6 & abs. & $F$ & abs. & 9 & abs. & $\%$ & aing: & $\%$ & 230. & $\%$ & 2600. & 9 & 268. & 4 & sbu. & 9 & ast. & 7 \\
\hline Patririo & 429 & 13,79 & 289 & 48,06 & 49 & 11,42 & 38 & 8,86 & 93 & 21,68 & 1 & 0,23 & 31 & 7,23 & 8. & 1,86 & 3 & 0,70 & 24 & 3.26 & 3 & 0,10 \\
\hline Sceundirso & 288 & 6,04 & 12 & 6,38 & 79 & 42,02 & 14 & 7,45 & 53 & 30,29 & - & - & 9 & 4,79 & $\because$ & - & 13 & 6,92 & 7 & 3,72 & 2 & 0,33 \\
\hline Perc.Comúrelo & 271 & 5,49 & 7 & 4,09 & 16 & 9,36 & 72 & 42,11 & ; & $33,92$. & - & - & 7 & (1,09) & 2 & 1,17 & 7 & $4,09$. & 2 & 1,17 & - & 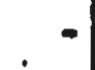 \\
\hline Terc.Servaço & 402 & 12,92 & 6 & 1,49 & 17 & 4,23 & 23 & 5,72 & 266 & $60.17 \mid$ & 9 & 2,24 & 34 & 8,46 & 9 & 2,24 & 30 & 7,46 & 7 & 2,74 & 2 & 0,23 \\
\hline Lestudanteo & 349 & 21,21 & 1 & 0,29 & 11 & 3.25 & 13 & 3.72 & 282 & 52,15 & $1: 2$ & 34,96 & 11 & 3,25 & 8 & 2,29 & - & - & $2 \cdot$ & 0,23 & - & - \\
\hline Pr.Dzmísticu| & 622 & $29,9 \%$ & 2 & 0,32 & 3 & 0,48 & 4 & 0,64 & 31 & 4,99 & 1 & 0,16 & 580 & 93.25 & 1 & 0,16 & - & - & - & -1 & - & - \\
\hline S/ Darladgeto & 952 & 30,56 & 39 & 6,20 & 54 & 5,68 & 48 & 5,05 & 275 & 18,40 & 156 & 20,61 & 133 & 23,96 & 270 & 28,39 & 1 & 0,11 & .20 & 1,05 & 5 & 0,23 \\
\hline TOT 16 & 3.112 & $\mid 100, \infty)$ & 276 & 8,87 & 229 & 7,36 & 212 & $6, B 1$ & 858 & $a 7,57$ & 32) & 10,57 & 805 & 25,87 & 298 & 9,57 & 54 & 2,74 & 41 & 2,32 & 20 & 0,32 \\
\hline
\end{tabular}

A presença, na cidade de população com atividades primā rias, isto é, daqueles que ainda têm a sua atividade no campo $(8,878)$, é caracterizada principalmente por dois ramos: o pro prietário rural, que faz da cidade a sua residência, e o assala 
riado rural, que é na sua maioria recrutado para os trabalhos ru rais durante as safras, plantios, conservação de pastos. Dos 276 rurais residentes na cidade, 17,398 são proprietários rurais e 82,618 const1tuem os assalariados, sendo 66,308 bóias-frias , 14,498 comvínculo empregatício (empregados com vencimentos men sais, administradores), 1,098 como tratoristas rurais. Apenas 0,728 declaram ser arrendatários.

o setor primário, considerando-se a atividade anterior e a atividade atual, apresentava na primeira fase 429 pessoas, re presentando 13,798 da população potencialmente ativa, enquanto que na segunda este número cai para 276, representando apenas 8,86\%. Portanto, entre uma fase e outra hā um decréscimo de 153 pessoas, o que significa uma queda de 28,048 no setor.

Dos 276 que na fase atual têm atividades primárias, 189 $(44,068)$ constituem aqueles que não mudaram de atividade, istoé, permaneceram no próprio setor. Aqueles que deixam o primārio, 55,948, o fazem principalmente para o terciário de serviços $(21,688)$ e para o secundário $(11,42 \%)$. Estes fatos podem ser. me Ihor apreendidos pela Tabela 29.

As opções para o terciārio de serviços voltam-se princí. paimente para os serviços públicos e transportes. Nos serviços püblicos as atividades mais procuradas estão ligadas ao Horto Florestal, Posto de Sementes, CEAGESP, que constituem atividades do terciário nitidamente ligadas ao primário, ou para o DER e serviços públicos municipais, principalmente para os trabalhos que requerem pouca qualificação. Nos transportes destacam-se os motoristas e ferroviários. Para as demais atividades deste ter ciārio hã una dispersão que vai desde os serviços bancários aos de empregadas domésticas e lavadeiras.

As transferências do setor primário para o secundário são feitas principalmente em função da existência de indústrias de óleos vegetais e beneficiamentos de produtos rurais ( Anderson\& clayton, Cia. SAAD, beneficiamento de arroz, café, serraria ) , que os recrutam na forma de empreitadas ou para determinados pe ríodos (época das safras), ou da expansão da construção civil. Os que se voltam para o terciário de comércio ( 8,86\%), apresentam um pequeno número que se torna proprietário ( comer ciante) e os demais passam a ser balconistas, auxiliares, en tregãiores, caixas.

Esta população, exceto os proprietários rurais, do setor primário geralmente pouco qualificada, ao fixar-se na cidade de 
bate-se com problema de emprego, isto porque tem que concorrer no mercado de trabalho, sendo limitada pela sua qualificação ou pela limitação natural das próprias condições econômicas da cidade. Face a isto observa-se que o setor primário, embora com decréscimo de aproximdadmente $56 \%$ entre uma fase e outra, ainda è expressivo na estrutura das atividades, evidenciando a presen ça de uma população que foi expulsa do campo em função das muaan ças que ocorrem na economia municipal e áreas próximas, por problemas advindos da atitude capitalista assumida pelos: próprietários rurais reforçada pelo Estatuto do Trabalhador Rural, ou que foi atraída pelas possiveis melhores condiçōes que a cí dade poderia oferecer.

o setor secundário entre uma fase e outra apresenta cres cimento de 21,80\%, ou seja, eram 185 na fase anterior e na atual somam 229, caracterizado principalmente pela presença daqueles que não definiram ou declaram não ter uma profissão e dos oriun dos do sètor primário. Considerando-se apenas o secundário, ve rifica-se uma permanência de 42,028 e conseqüentemente um de créscimo de 57,988 que ocorre em benefício dos demais setores , principalmente do terciário de serviços acentuando-se uma "vez mais a opção pelos serviços püblicos. Este fato parece delinear uma procura de segurança econômico-social, pois, ao lado destes que se definem para estas atividades hã aqueles que de uma ati vidade instável no secundário voltam-se para subempregos do ter clário de serviços (bilheteiros, serviços ambulantes, carroceiros, guardas).

o terciário de comércio tem comportamento semelhante ao secundário, com um crescimento de 23,988 , isto é, entre uma fa se e outra passam de 171 para 212. Considerando-se apenas o se tor, verifica-se o decréscimo expressivo de 57,898, uma vez que permanecem no setor apenas 42,118. A mudança se faz para as de mais atividades, com maior número para o terciário de serviços, acentuando-se novamente a opção para os serviços püblicos e dos transportes. o crescimento deste terciārio se faz à custa daque les que vem do primārio e daqueles que não apresentavam uma de finição profissional na fase anterior.

o terciário de serviços é o que se apresenta mais expressivo na composição das atividades e è, tambēm, o de maior crescimento: de 402 na atividade na fase anterior, salta para 858 na atual, significando aumento de 113,43\% . Analisando-se apenas o setor este apresenta decrēscimo menor em relação aos demais - 33,83\%. 
Estes que o deixam distribuem-se pelos demais, havendo predomi nância para o comércio e para as prendas domésticas. Como exce ção, este é o setor que apresenta maior número de aposentados, constituindo $7,46 \%$ deste decréscimo.

o crescimento é definido pelo grupo de estudantes e por aqueles sem definição profissional na fase anterior, reforçado pelos oriundos do primārio, terciārio de comércio e secundário, como foi visto nas considerações anteriores, embora em proporf̧ões bem menores.

As opções verificadas para o terciārio de serviços ou dê tro dele, voltam-se principalmente para os serviços públicos, professores (embora estes também constituam, na sua quase tota lidade, servidores püblicos), empregadas domésticas, motoristas e mecânicos.

De certa forma estabelece-se neste setor o que jā foi vis to nas considerações sobre os demais setores: a população do ponto de vista profissional procura alcançar a sua segurança eco nômico-social através dos serviços públicos (vista uma fase e outra, quando a população os alcança na primeira, raramente há mudanças), ou atravēs de melhor qualificação, seja por estudos' ou "estágios" como é o caso de professores e pessoal empregadoem escritórios, bancos não oficiais (estes geralmente, com exceção dos que ocupam posições de chefia, aguardam nestes empregos 0 momerto de prestar um concurso público). Ao lado destes hā uma parcela significativa de pessoas sem qualificação (empregadas do mésticas) ou semi-qualificados (motoristas, mecânicos - nestes últimos os mais qualificados estão ligados às agências autoriza das da Ford, Volkswagem, Chevrolet ou à Anderson \& Clayton).

Completando o quadro do terciário de serviços há, além dos profissionais liberais - que em algumas profissões não aten dem às necessidades do centro urbano -, uma variedade de ativi dades, próprias de um pequeno núcleo urbano, mas que não chegam a constituir, em cada profissão, número representativo (eletricistas, sapateiros, garçons, barbeiros, poceiros, manicures, e etc.).

Finalmente dentro desta análise restam os não economíca mente ativos, isto é, os sem definição profissional, prendas dô mésticas é estudantes.

Neste conjunto só se considerará aqueíes que não definiram ou declararam não ter uma profissão ou atividade na fase an terior e aos estudantes. Exclui-se as prendas domésticas porque 
têm pouquíssima participação nos demais setores de atividades - crescimento apresentado advém do grupo que não define uma pró fissão ou atividade na fase anterior.

Os estudantes entre uma fase e outra apresentam relativa estabilidade. Observa-se entre a fase anterior e a atual que aqueles que deixam de ser estudantes ou pelo menos assim o de claram, definem-se para o terciārio de serviços $(52,158)$ onde as atividades de escritório, serviços públicos, são os preferidos (10\%)-. Os novos estudantes provêm daqueles que na fase ante rior não possuíam qualquer atividade, assim declarado, principa 1 mente pela pouca idade.

o grupo daqueles que não definem uma atividade apresenta uma participação expressiva na fase anterior - 30,56\% -, redu zindo-se na segunda fase a 9,57\%. Este decrēscimo reparte-se pe las diferentes atividades, havendo uma relativa igualdade para os setores primário, secundário e terciário de comércio. o tex ciārio de serviços ao lado dos estudantes e prendas domésticas, são os que recebem a grande maioria ( no conjunto aproximadamen te 538). Os que se encaixam no terciário de serviços $(20,61 \%), 0$ fazem para as atividades de escritório, serviços públicọs, hos pitaịs e llads de $25 \bar{z}$ turnaume empregaảas àomésticas.

\subsection{Estrutura Econômica da População Urbàna}

Procurar-se-á apresentar a estrutura econômica desta po pulação através dos rendimentos auferidos tanto no global, por setor de atividade e renda per capita, em termos mensais, quanto pela condição de liso do domicílio e pelo acesso que esta tem a um grupo de bens de consumo durāvel.

Quanto ao rendimento familiar, os resultados obtidos abian gem 874 familias (45), considerandc-se as rendas de proprietários (comerciantes, industriais, fazendeiros), salários e reıdi. mentos extra-salariais (pensōes, aposentadorias, auxilios, etc).

Tomando-se o conjunto, o rendimento familiar médio mensal apresentava-se em fins de 1971, início de 1972 (época dos levan tamentos) em torno de 3,37 salários mínimos regional. (46)

(45) Abrangeu-se apenas este nünero de famílias, de um total de 981 , pelo fato de que estas forneceram as informaçóes de. sejadas.

(46) Salário mínimo regional, na época $=\operatorname{cr} \$ 216,00$ 
Entretanto, vistas as diferentes classes salariais, o rendimento familiar médio mensal de $70 \%$ das famillias é inferior a esta média mensal, dos quais, 258 recebiam menos de 1 salário mínimo.

Por consegüiència, quando se observa os rendimentos totais pagos a esta população, verifica-se que $41,96 \%$ destes destinam -se a 77,238 das familias que recebem abaixo de 4 salários míni mos, enquanto que 21,378 destes rendimentos voltam-se a apenas 3,838 das famílias, situadas na classe acima de 12 salários mí nimos. (Tabela 30 , figura 5 ).

Distribuição da renda média mensal familiar e total recebido por classe salarial.

Paraguaçu Paulista - Amostragem - 1971/72 Tabela 30

\begin{tabular}{|c|c|c|c|c|}
\hline $\begin{array}{l}\text { Classe salarial } \\
\text { (sal. mínimos) }\end{array}$ & $\begin{array}{l}\text { No de famillas } \\
\text { por classe sal. }\end{array}$ & 8 & $\begin{array}{l}\text { Total recebido } \\
\text { por classe sal. }\end{array}$ & 8 \\
\hline $2 \mathrm{sal}$ & 412 & 47,13 & $106.494,00$ & 16,61 \\
\hline 2 a 4 sal. & 263 & 30,10 & $162.490,00$ & 25,35 \\
\hline 4 a 6 sal. & 79 & 9.02 & $75.790,00$ & 11,83 \\
\hline 6 a 8 sal. & 41 & 4,79 & $66.100,00$ & 10,31 \\
\hline 8 a 10 sal. & 35 & 4,00 & $69.200,00$ & 10,80 \\
\hline 10 a 12 sal. & 10 & 1.13 & 23.900 .00 & 3.73 \\
\hline+ de 12 sal. & 34 & 3,83 & $137.000,00$ & 21,37 \\
\hline TOTAL & 874 & 100,00 & $640.974,00$ & 100,00 \\
\hline
\end{tabular}

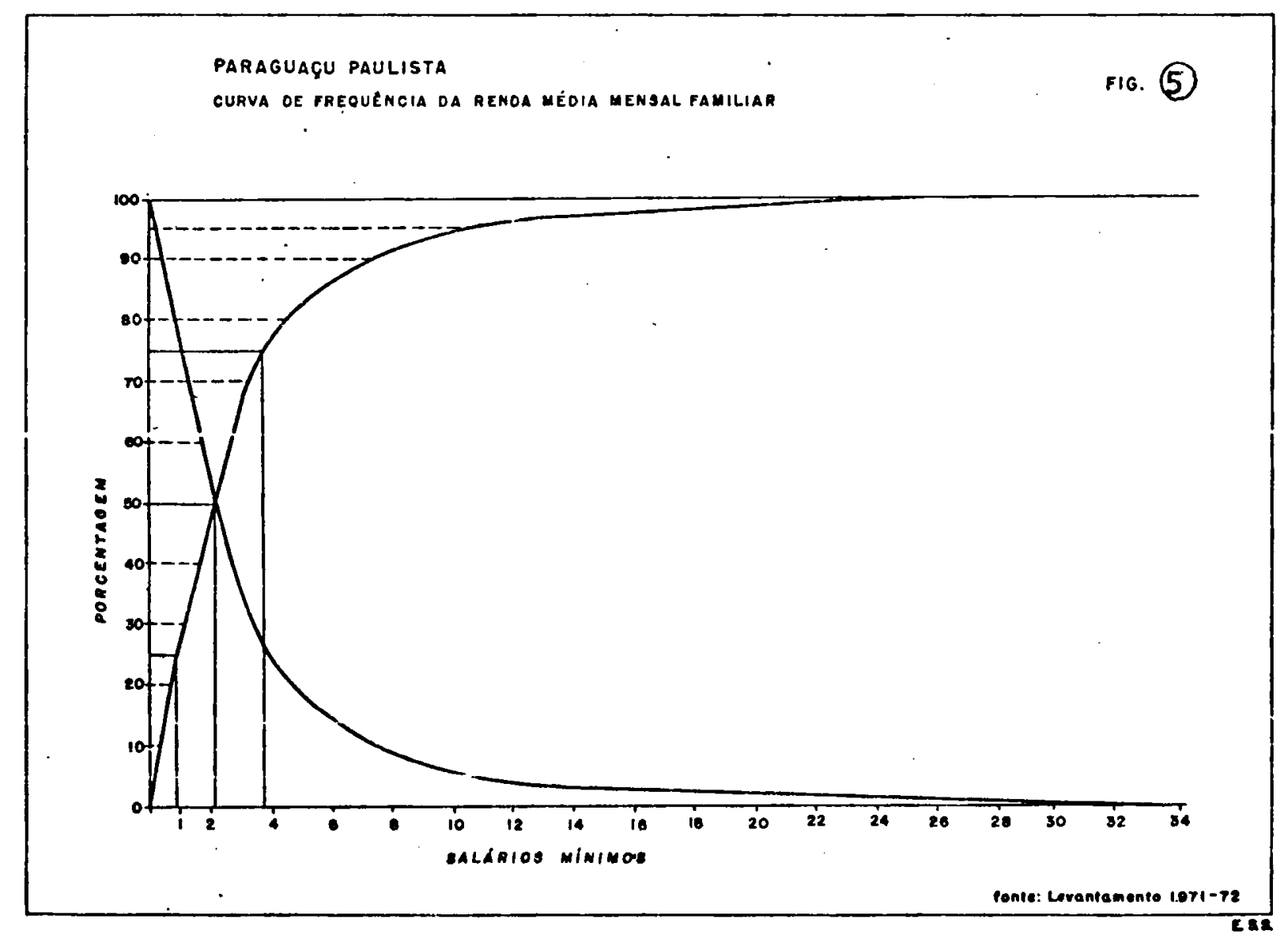


Ao nível dos setores de atividades, os menores rendimen tos são encontrados no secundārio, onde a média mensal familiar estā em torno de 2,29 salários mínimos e mais de 788 da popula ção do setor apresenta rendimentos abaixo da média mensal fami liar geral (3,37 salārios mínimos). No setor primārio a renda mé dia mensal familiar apontava 4,55 salários mínimos e aproximada mente 608 do setor recebla abaixo do rendimento médio mensalge ral. Para o terciărio de comércio e serviços, verifica-se me lhoria razoável nos rendimentos médios, sendo que o primeiro a presenta melhores níveis. para o terciário de serviços, o rendi mento médio mensal familiar è de 5,38 salārios mínimos, com apro ximadamente 508 abaixo da média geral. O terciário de comércio tem renda mensal familiar em torno de 6,38 salários mínimos e aproximadamente $40 z$ do setor recebendo abaixo da renda médiage ral, que é de 3,37 salários mínimos. (Figura 6)

Outro aspecto a ser analisado, quanto à estrutura econô mica desta população, refere-se à renda mensal "per capita".

Esta constituindo-se um aspecto detalhado daquele da ren da média mensal familiar, reforça e evidencia um baixo rendimen to econômico da população.

Consiāeranao-se a renáa mëala mensa "per capıta", veriti ca-se que a mesma corresponde a $1 / 5$ da renda méaiia mensal famí liar, caindo aníveis extremamente baixos nas classes econômicamente inferiores. Reforçando este fato tem-se uma despropor ção entre a população da classe de 0 a -2 salários mínimos e aquela acima de 10 salários mínimos da ordem de 1 para 15. (Tabela31).

Renda Média Mensal "per capita"

Paraguaçu Faulista - Amostragem - 1971/72 Tabela 31

\begin{tabular}{|c|c|c|c|c|c|c|c|}
\hline CLAS & & SALARIAL & NQ DE FAMILIAS & $\begin{array}{l}\text { TOTAL DE } \\
\text { PESSOAS }\end{array}$ & $\begin{array}{l}\text { TOTAL NLNSAL RECE } \\
\text { BIDO NA CLASSE }\end{array}$ & $\begin{array}{ll}\text { RENDA PER } \\
\text { CAPITA MENSAL }\end{array}$ & $\begin{array}{l}\text { NQ MEDIO DE } \\
\text { PESSONS P/FAM. }\end{array}$ \\
\hline 0 & a & - 2 sal. & 412 & 1.715 & $106.494,00$ & 62,10 & 4,2 \\
\hline 2 & a & - 1 sal. & 263 & 1.656 & $162.490,00$ & 98,10 & 6,3 \\
\hline 4 & a & - 6 sal. & 79 & 396 & $75.790,00$ & 191,40 & 5,0 \\
\hline 6 & a & - 8 sal. & 42 & 222 & $66.100,00$ & 297,70 & 5,4 \\
\hline 8 & a & -10 sal. & 35 & 156 & $69.200,00$ & 443,60 & 4,5 \\
\hline 10 & e & ma1s & 44 & 204 & 160.900 .00 & 788,70 & 4,6 \\
\hline \multicolumn{3}{|c|}{ T०ta $1 \mathrm{~s}$} & 874 & 4.349 & $640.974,00$ & 145,80 & 5,0 \\
\hline
\end{tabular}

Finalmente, completando o quadro de análises, procurou -se verificar o acesso desta população urbana quanto à posse de 


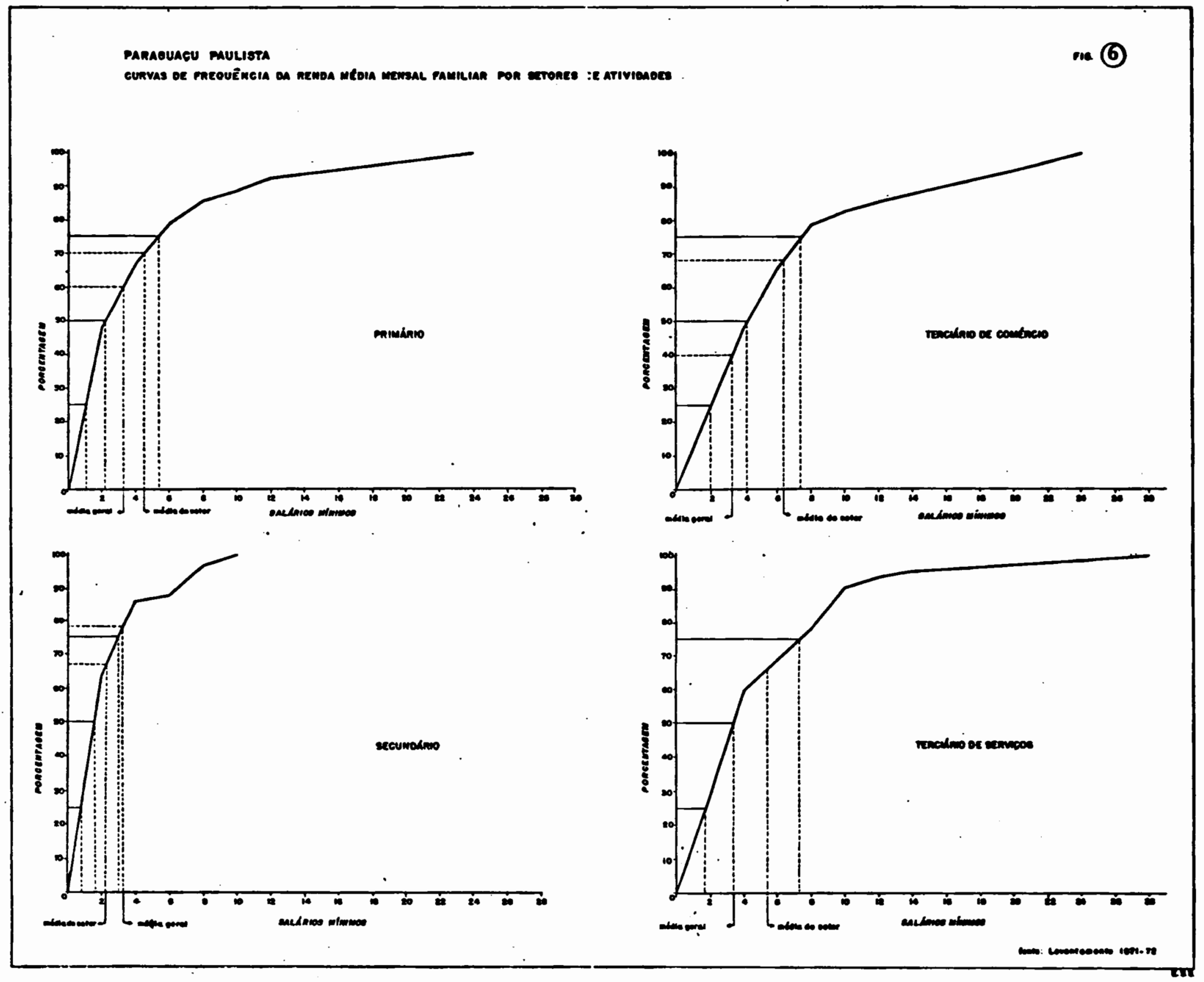


domicílio e alguns bens de consumo durável (rádio, fogão a gāz, geladelra, liquiidificador, rádio-vitrola, enceradeira, televisão, carro). Estas análises foram feltas com base em levantamento re alizado no início de 1971. ( 47 ).

Face ao tipo de levantamento realizado e para melhores / condições de anālises, agrupou-se a população em 5 classes, sen do 4 com a amplitude de 2 salários mínimos e a última, com limi te superior em aberto, abrangendo as frequêencias além de 8 sala rios minimos. ('Tabela 32)

Quanto à condição de posse do domicílio, verifica-se que pouco mais de $70 z$ da população possui domicílio próprio, apre sentando conseqüentemente a condição de inquilinos para poucome nos de 308 .

Vista a participação desta condição de posse do domicilio por classe salarial, verifica-se que mesmo na primeira delas, is to é, de 0 a -2 salários, a condição de domicílio próprio é ele vada, estando próxima de $67 \%$ (48), chegando a pouco mais de $86 \%$ na classe acima de 8 salārios mínimos.

Quanto à posse dos bens de consumo durável, verifica-se que hã um acesso relativamente grande ao rádio e fogão a gáz em

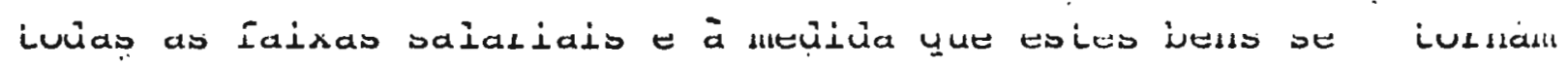
mais sofisticados ou de maior valor, sua presença é definida ou acentuada a partir da classe de 6 salāriós minimos, inclusivepa ra os carros. (Tabela 32 : Figura 7 )

Assim, a estrutura profissional e econômica da população apresenta grande instabilidade ocupacional, definida pela mobi lidade não só daqueles vinculados ao setor primārio, como dos vinculados aos outros setores considerados mais urbanos. Esta instabilidade tem, ao que parece, várias causas entre as quais pode-se citar as transformações ras relações de trabalho no cam po, ocupação das terras pela pecuária e à falta de dinamismo dá

(47) Este levantamento, considerado preliminar, constituiu na aplicação de pouco mais de 500 questionários na população urbana (domiciliares), tendo em vista linhas para poste riores levantamentos.

(48) Observações diretas feitas a estes domicílios, mostraram tratar-se na sua grande maioria de casas de madeira, cons truídas hà mais de 25 ou 30 anos, sem pintura ou com umá simples caiaj̃o, deşastadas pelo tcmpo, pequenas (šcralmente com 4 comodos), muitas delas com instalações sanitá rias que se resumem na "casinha" com fossa negra. 
Distribuição percentual por faixa salarial, com condição de posse do domicillo e de bens de consumo durável População urbana de Paraguaçu Paulista

Levantamento preliminar de 1971.

Tabela 32

\begin{tabular}{|c|c|c|c|c|c|c|c|c|c|c|c|c|c|c|c|c|c|c|c|c|c|c|}
\hline \multicolumn{3}{|c|}{ RENDIMENTOS } & \multicolumn{4}{|c|}{ DOMICILIO } & \multicolumn{2}{|c|}{ RADIO } & \multicolumn{2}{|c|}{ FOG. AGAS } & \multicolumn{2}{|c|}{ GELAADEIRA } & \multicolumn{2}{|c|}{ IIQUIDIE. } & \multicolumn{2}{|c|}{ RAD.VITR. } & \multicolumn{2}{|c|}{ - ENCERAD. } & \multicolumn{2}{|c|}{ TELEVISÃO } & \multicolumn{2}{|c|}{ CARRO } \\
\hline \multirow{2}{*}{$\begin{array}{l}\text { Classe } \\
\text { de } \\
\text { salärto }\end{array}$} & \multirow{2}{*}{$\begin{array}{l}\text { Número } \\
\text { defami- } \\
\text { lias na } \\
\text { classe } \\
\text { salarial }\end{array}$} & \multirow{2}{*}{8} & \multicolumn{2}{|c|}{ Próprio } & \multicolumn{2}{|c|}{ Alugado } & \multirow{2}{*}{ abs } & \multirow{2}{*}{8} & \multirow{2}{*}{ abs } & \multirow{2}{*}{8} & \multirow{2}{*}{ abs } & \multirow{2}{*}{8} & \multirow{2}{*}{ abs } & \multirow{2}{*}{8} & \multirow{2}{*}{ abs } & \multirow{2}{*}{8} & \multirow{2}{*}{ abs } & \multirow{2}{*}{8} & \multirow{2}{*}{ abs } & & \multirow{2}{*}{ abs } & \\
\hline & & & abs. & $z$ & abs. & $x$ & & & & & & & & & & & & & & & & \\
\hline de 0 a -2 & 278 & 54,30 & 186 & 66,91 & 92 & 33,09 & 214 & 76,98 & 196 & 70,50 & 59 & 21,22 & 45 & 16,19 & 36 & 12,95 & 29 & 10,43 & 29 & 10,43 & 5 & 180 \\
\hline de 2 a -4 & 125 & 24,41 & 87 & 69,60 & 38 & 30,40 & 118 & 94,40 & 116 & 92,80 & 75 & 60,00 & 48 & 38,40 & 39 & 31,20 & 43 & 34,40 & 44 & 39,20 & 16 & 1280 \\
\hline de 4 a -6 & 59 & 11,52 & 49 & 83,05 & 10 & 16,95 & 55 & 93,22 & 57 & 96,61 & 43 & 72,88 & 32 & 54,24 & 20 & 33,90 & 37 & 62,71 & 38 & 64,41 & 23 & 38,98 \\
\hline de 6 a -8 & 13 & 2,54 & 7 & 53,85 & 6 & 46,15 & 12 & 92,31 & 13 & 500,00 & 12 & 92,31 & 7 & 53,85 & 6 & 46,15 & 11 & 84,62 & 11 & 84,62 & 8 & 61,54 \\
\hline+ de 8 & 37 & 7,23 & 32 & 86,49 & 5 & 13,51 & 35 & 94,59 & 37 & $.200,00$ & 34 & 91,89 & 24 & 64,86 & 27 & 72,97 & 30 & 81,08 & 32 & 86,49 & 25 & 67,58 \\
\hline T O T A L & 512 & 100,00 & 361 & 70,51 & 151 & 29,49 & 434 & 84.77 & 419 & 81,85 & 223 & 43,55 & 156 & 30,47 & 128 & 25,00 & 150 & 29,30 & 154 & 30,07 & 77 & 15,03 \\
\hline
\end{tabular}

Fonte: Levantamento preliminar realizado no inicio de 1971

Obs. As percentagens sobre rendimentos foram cálculadas $\because$ com base no total das classes de salário $=512$. As demais foram calculadas com base no número absoluto da classe salarial.- 


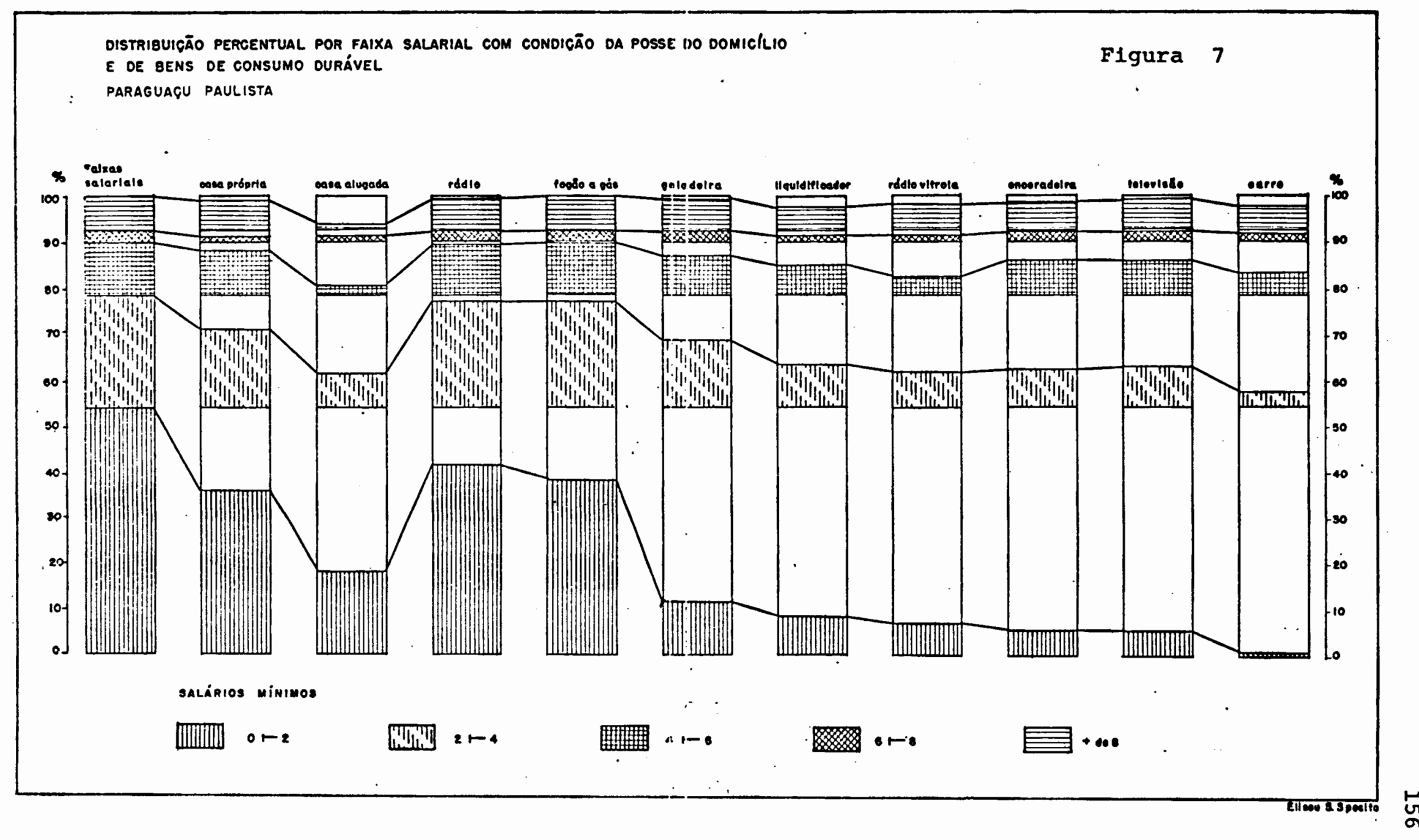


economia urbana, que não crescendo en ritmo capaz de ampliar as oportunidades de trabalho ou de absorver esta mão-de-obra , faz com que ela se volte para atividades de baixa produtividade, na forma de subempregos no terciārio, secundārio ou na própria zona rural.

Tem-se portanto uma população que do ponto de vista pro fissional e das suas condições econômicas, apresenta-se vincula da na sua maioria aos setores de menor produtividade do siste ma econômico, demonstradas pela presença de atividades que pou co ou quase nada exigem em termos de qualifícação e, conseqüen temente, gerando baixos rendimentos.

Como conseqüência do reduzido rendimento, o poder aquisi tivo é muito pequeno, refletindo-se diretamente sobre o ni vel de consumo. Este ūltimo aspecto parece apresentar-se em oposição aos fatos descritos, principalmente quanto à posse de domicilio por uma população de baixo rendimento Entretanto , do que se verificou, essa posse è na sua maioria de períocios relativamente longos (perto de $40 \%$ dos domícilios particula res permanentes, apresentam um tempo de residência superior a 7 anos - Censo de 1970), de uma data onde a especulação e va lorização dos imóveis pouco incidiam sobre o consumo e que re fletem a falta de dinamismo urbano nesse periodo. Atualmen te a aquisição de uma casa constitui privilégio de pequena par cela da população que apresenta pelo menos uma garantia sala rial ou então a posse de um terreno, o que significa uma certa poupança. 


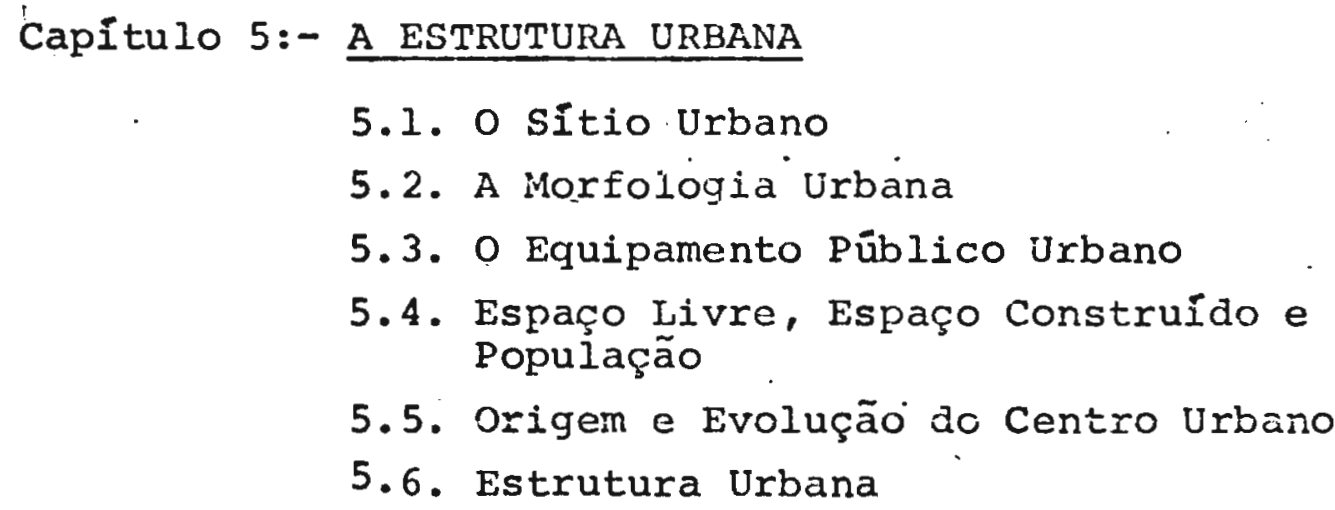




\section{A ESTRUTURA URBANA}

\subsection{Sítio Urbano}

Através da análise da carta topogrāfica ( 49 ), verifí ca-se que o nücleo urbano de Paraguaçu Paulista estabelece-se em um sítio com felções planas, com altitude média de 500 me tros, ocupando parte do espigão divisor dos ribeiröes do Alegre (leste) e do Sapé (oeste) que correm ,paralelos e com direção / norte-sul. As declividades são mais acentuadas no sentido de um e outro ribeirão: a partir do espigão, no sentido do Alegre, es ta é de 4z, enquanto que para o Sapé suaviza-se alcançando 38 (perfil A). No sentido norte-sul sente-se a planura do sitio, através dos $0,5 \%$ de declividade que este apresenta. (perfil B).

Do ponto de vista geológico, este espaço é constituído' por uma ārea ocupada na sua totalidade por sedimentos cenózcicos indiscriminados, sobrejazentes à Formação Bauru e cuja espessú ra observada está em torno dos 60 metros. (Secção Geólógica en tré os Ribeirões do Sapé e Alegre).

o maior adensamento urbano encontra-se na vertente que corresponde à margem direita do Ribeirão Alegre. Nos ūitimos anos o núcleo urbano, transbordando o espigão, iniciou a ocupa ção da vertente esquerda do Sapé.

Estas feições geomorfológicas, geológicas e a localização da cidade dentro deste quadro, constituíram fatores favorāveis' ou tornaram-se problemas para está na sua evolução.

Nascendo na meia vertente do Alegre, expandindo-se ao lon go desta em sentido ao ribeirão e mais rapiaamente em sentidoac espigão, dentro de um quadro topogrā́fico suave, o traçado das ruas fez-se de forma ortogonal, quebrando a sua monotonia em al guns pontos da cj.dade, não no traçado em si, mas em relação ao conjunto, resultado mais do processo de loteamento com se verá mais adiante.

A topografia facilitou a instalação das redes de águas e esgotos. A rede de águas, com seu sistema de tratamento e arma zenamento localizado no espigão, teve na declividade das verten tes a queda natural, facilitando o abastecimento da cidade. A rede de esgotos, da mesma forma, foi implantada aproveitando-se deste fator, tendo seu emissário desaguando no Ribeirão Alegre.

\footnotetext{
(49) - Faraglaçu Paulista - fôlha SF-22-Z-A-I-4, Carta do Bra sil na escala de $1: 50.000$. IBGE, Superintendencia de Cartografia, Departamento de Cartografia. Primeira Edi ção, 1974.-
} 
Entretanto, a partir do momento em que a cidade inicia sua expansão para a vertente do Sapé, a topografia, que até en tão se constituíra em fator favorável a este melhoramento, pas sa a representar problema, uma vez que toda a rede coletora es tá definida na vertente oposta.

No que toca à Geologia, a camada sedimentar pouco consis tente, constituida por material areno-argiloso e conglomerados fracamente consolidados, de textura média, com ausência total de cimento, não ofereceu dificuldades para a implantação das re des de águas e esgotos, se analisado este fato apenas do ponto de vista técnico. Entretanto, estas características somadas às da localização da maior parte da cidade na vertente com maior de clividade e o traçado das ruas, favorecendo a concentração e es coamento das águas pluviais em sentido ao Ribeirão Alegre, de ram origem a voçorocas que constituíram ameaças, ou antes, im pedimentos à expansão da cidade nessa ārea. Já a área da cidade localizada na vertente do Ribeirão Sapé,-embora a rocha possua as mesmas características, ainda não apresenta estes problemas, pelo fato de que o escoamento é mais difuso em função não só da menor declividade, bem como da menor ocupação urbana ainda 'ca rente de melhoramentos püblicos tais como ruas sargeteadas, ga lerias, asfaltos, que favorecem a concentração das águas.

Ainda considerando estes aspectos-ageomorfologia e a Geo logia - um outro problema se propõe: a conservação das vias sem capeamento asfáltico, que após cada chuva apresentam valetea mentos, principalmente aquelas orientadas em direção aos ribei rões.

Com relação à construção civil, o solo urbano não apresen ta problemas de grande significância, não sendo, entretanto, con siảerado de boa qualidacie, una vez que as fundações para edifí cios tērreos têm sido feitas com profundidade de 4 a 5 metros, havendo casos que alcançam 7 a 8. Edifícios de 2 ou 3 pavimentos exigiriam fundações entre 8 e 12 metros.

Finalmente, considerando-se a futura expansão da cidade, observa-se que há boa reserva de espaço. As áreas mais favorā veis, quer pela topografia, quer pela presença ou facilidades / quanto à implantação dos equipamentos püblicos, ocorrem nos sen tidos norte (aeroporto, Jardim Panambi) e sul (vila Nova). En tretanto, a maior valorização e expansão verifica-se para oeste, no espaço existente na vertente esquerda do Ribeirāo Sapé, cujas condiçōes topográficas não são muito diversas àquelas do Ribei rão. Alegre, sendo, portanto, menos favorāveis, principalmente" considerando-se a necessidade e custos dos equipamentos públicos que deverão ser implantados. 

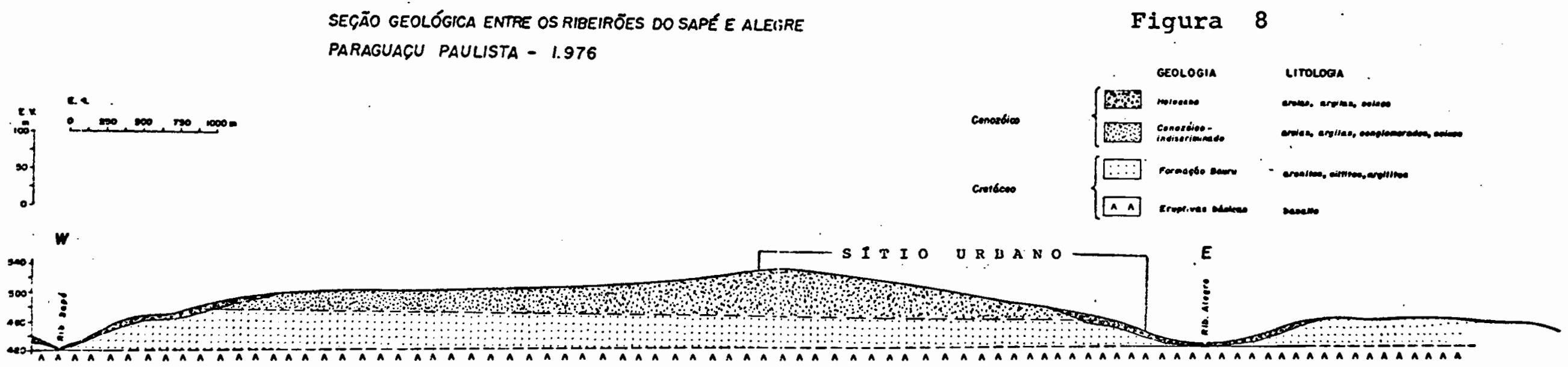

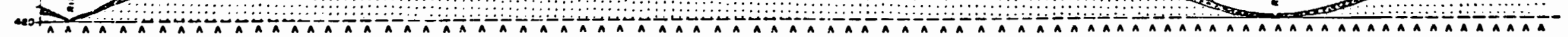

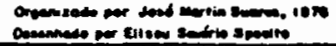

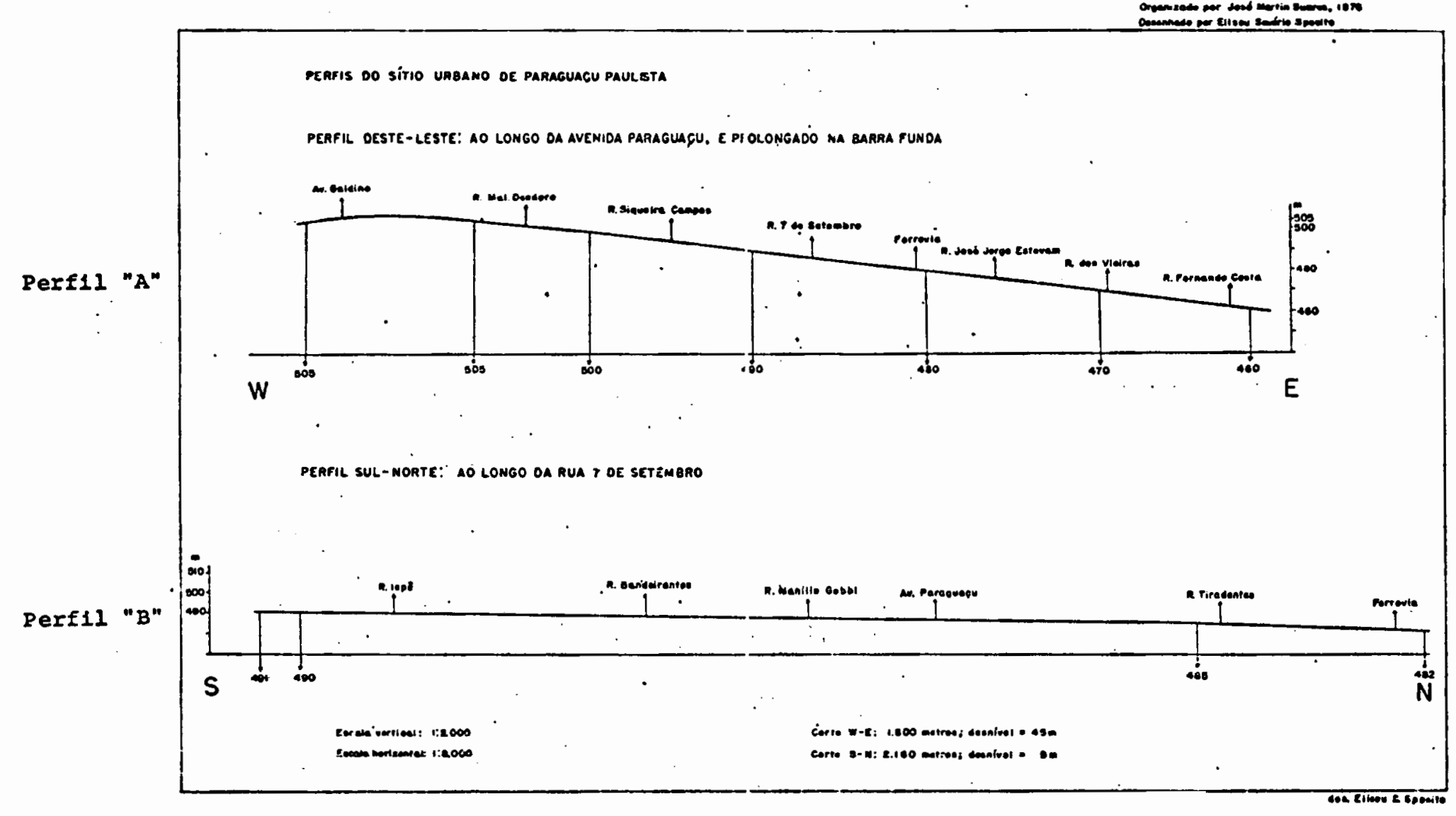




\subsection{Morfologia Urbana}

As construções urbamas em Paraguaçu Paulista apresentam em quase todo o espaço uma arquitetura mais ou menos homogênea, sim ples, onde as diferenças observadas são frutos do material em pregado, natureza do loteamento e aspectos econômicos, calcados na evolução histōrica.

A madeira constitui o material quase que exclusivo : nas construções até aproximadamente o final da década de 1920, quan do começaram a surgir as primeiras construções de tijolos ou a substituição de edificações daquele por este material.

Nesta fase e mesmo além, na década de 1930, a ocupação ab solo urbano foi, de certa forma extensivo, ou seja, com lotes amplos, com ausência de residências suntuosas que pudessem evi denciar um grande desenvolvimento econômico ou mesmo concentra ção de rendas na cidade.

o emprego do tijolo não subtrai o uso da madeira, persis tindo a sua presença até os dias atuais, embora diminuto, uma vez que o valor da construçāo neste material equipara-se à alve naria. Subsidiando este aspecto, a madeira tem o inconveniente de menor durabilidade e apresentar desvalorização razoável com o passar do tempo.

Um aspecto que já foi mais freqüente, mas de dificil pre sença nas construções recentes, é a construção mista: madeira e tijolos.

A medica que se definem no tempo as mudanças econômicas, desenvolvendo as funções urbanas com consequiente aumento da po pulação, o solo citadino passa a ser ocupado mais intensamente e mais valorizado.

A cidade evolui, verificando-se um modelamento na estrü tura imobiliāria (lotes), principalmente nas quadras mais anti gas e centrais, com aspecto funcional já delineado.

Neste espaço antigo e central do núcleo urbano, as cons truções na maioria de uso comercial e serviços, passam a refletiraivalorização e a forma dos terrenos. Abrem-se diretamente sobre as ruas, os seus espaços livres constituem estreltos cor reãores e à medida que se adensa o espaço construído, reduzem-se suas fachadas, constrói-se em altura ( não mais que dois pa vimentos), surgindo atualmente com formas alongadas fazendo de saparecer, inclusive, os vazios interiores das quadras. As resi 
dências, quando existem, ocupam o pavimento superior ou os fun dos da construção, sendo raras as isoladas (Planta da quadracen tral com predomínio do terciário, figura 9).

o aspecto arquitetōnico do conjunto è homogêneo e as nú ances nele observadas se devem à idade, reformas, sendo raras as construções novas.

Para fora desta área e próxima a ela, encontra-se uma su cessão de construções cujas plantas e terrenos são frutos da es peculação imobiliária e com interesse e valor particular. A construção modesta ou não, de alguma idade ou recente, ocupa o mais possivel a frente do terreno, restando um pequeno espaço, geralmente ocupado por um modesto jardim. Os fundos são bastan te amplos, constituindo um miolo vazio, arborizado e partilhan do cada quadra. Em ponto algum verifica-se pelo menos o esboço' de seu aproveitamento, o que poderia apresentar bons resultados em termos sociais, mas que do ponto de vista econômico torna-se inviável por constituir-se em elemento desvalorizador da proprí edade particular. (Planta da quadra com predomínio da classe mé diaj.,figura 10).

A medida que se avança para a periferia do núcleo urbano, os terrenos são mais amplos, resultantes da pequena valorização imobiliāria e ocupados por modestas consțuções, com predomínio da madeira, edificada na parte frontal, restando pequena faixa , geralmente pouco cuidacia, entre esia e a rua. A suá arquitetura é simples e se repete, restando muitas delas bastante deteriora das pelo tempo e revelando a condição econômica de seus proprie tários ou ocupantes. (Planta da quadra com predomínio da clas se pobres.figura 11 ).

Entretanto, estes não constituem, na cidade, os últimos estāgios de habitação ou forma de ocupação do solo. En certos pontos - Vila Nova e Barra Funda, principalmente - encontram-se algumas construçōes em taipa ou barracos. Construídas em barro, pau-a-pique, cobertas de sapé, de pisos de chão batido, sem as mínimas condições de higiene, elas ocupam um terreno que na mai oria das veses não é de sua propriedade, sendo habitadas por pọ pulação paupērrima, cuja presença mais marcante na cidade data dos últimos 15 a 20 anos.

Em oposição a estes aspectos, verifica-se nos ûltimos 5 a 10 anos maior valorização do terreno e adjacēncias da área cen tral e no extremo o-No da cidade, face à atração de investimentos 1mobiliários proporcionados pela concentração de rendas ad 

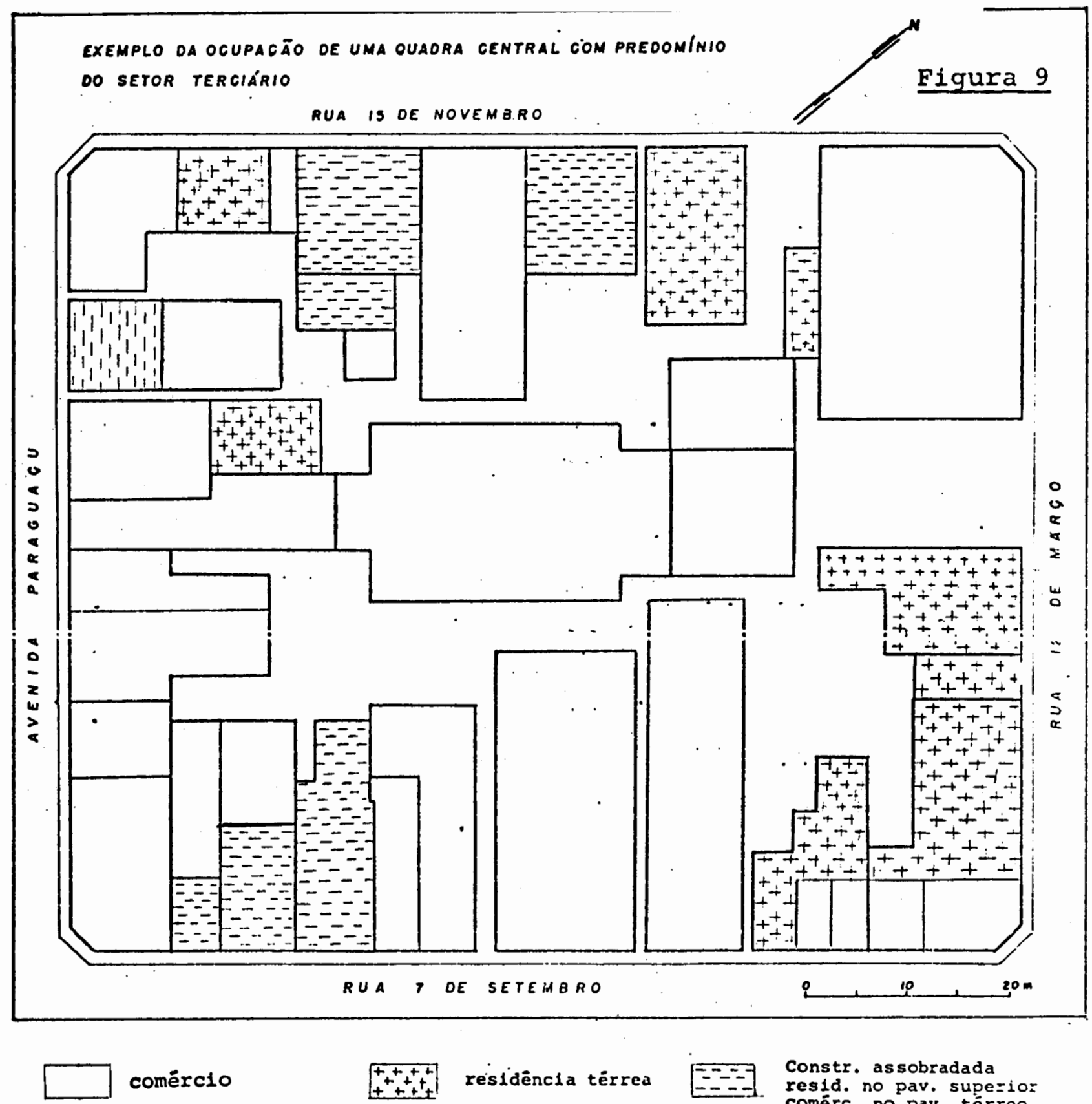

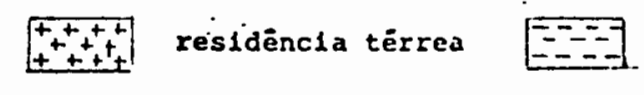

Constr. assobradada

resid. no pav. supezio:

comérc. no pav. térreo 


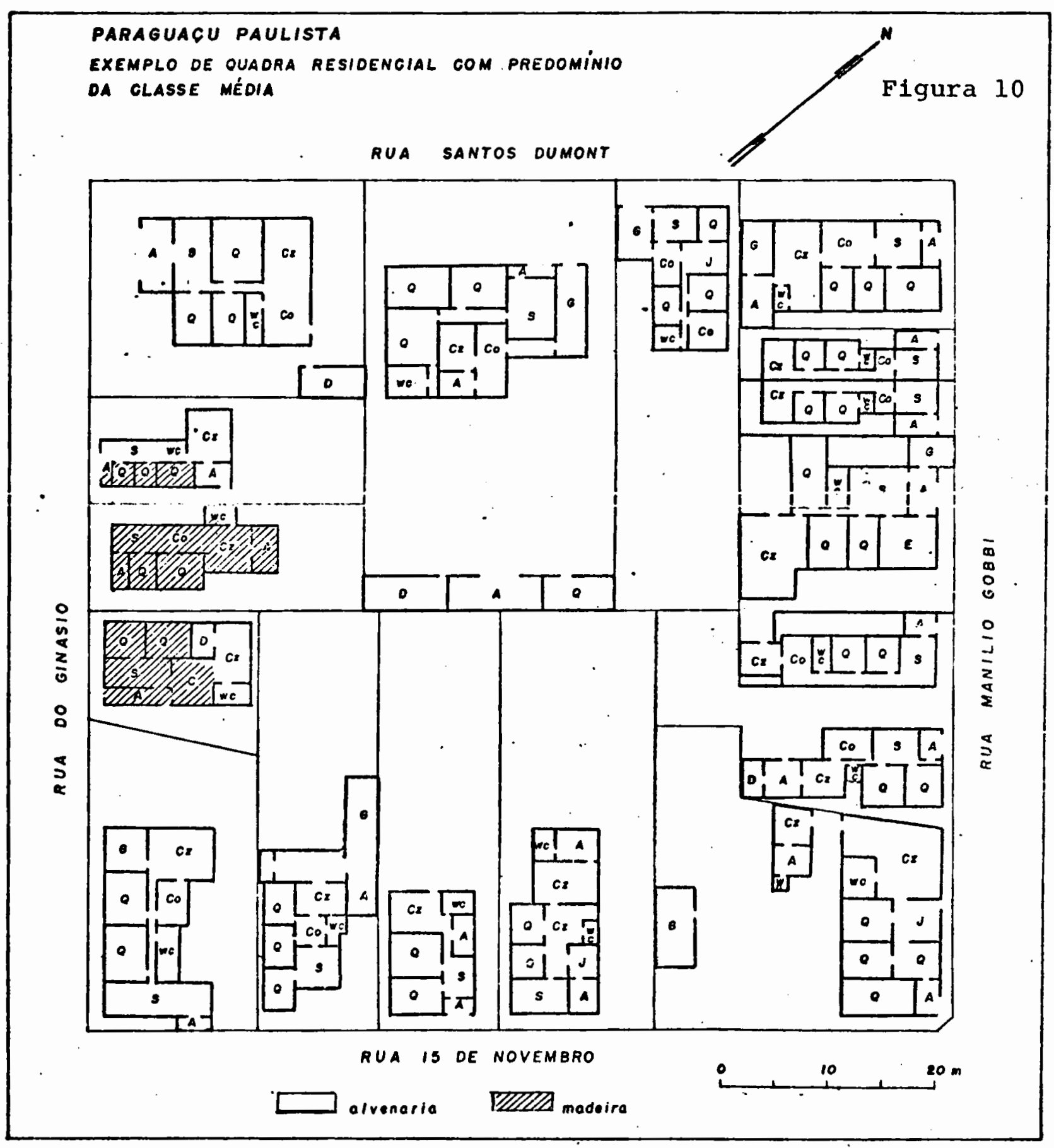




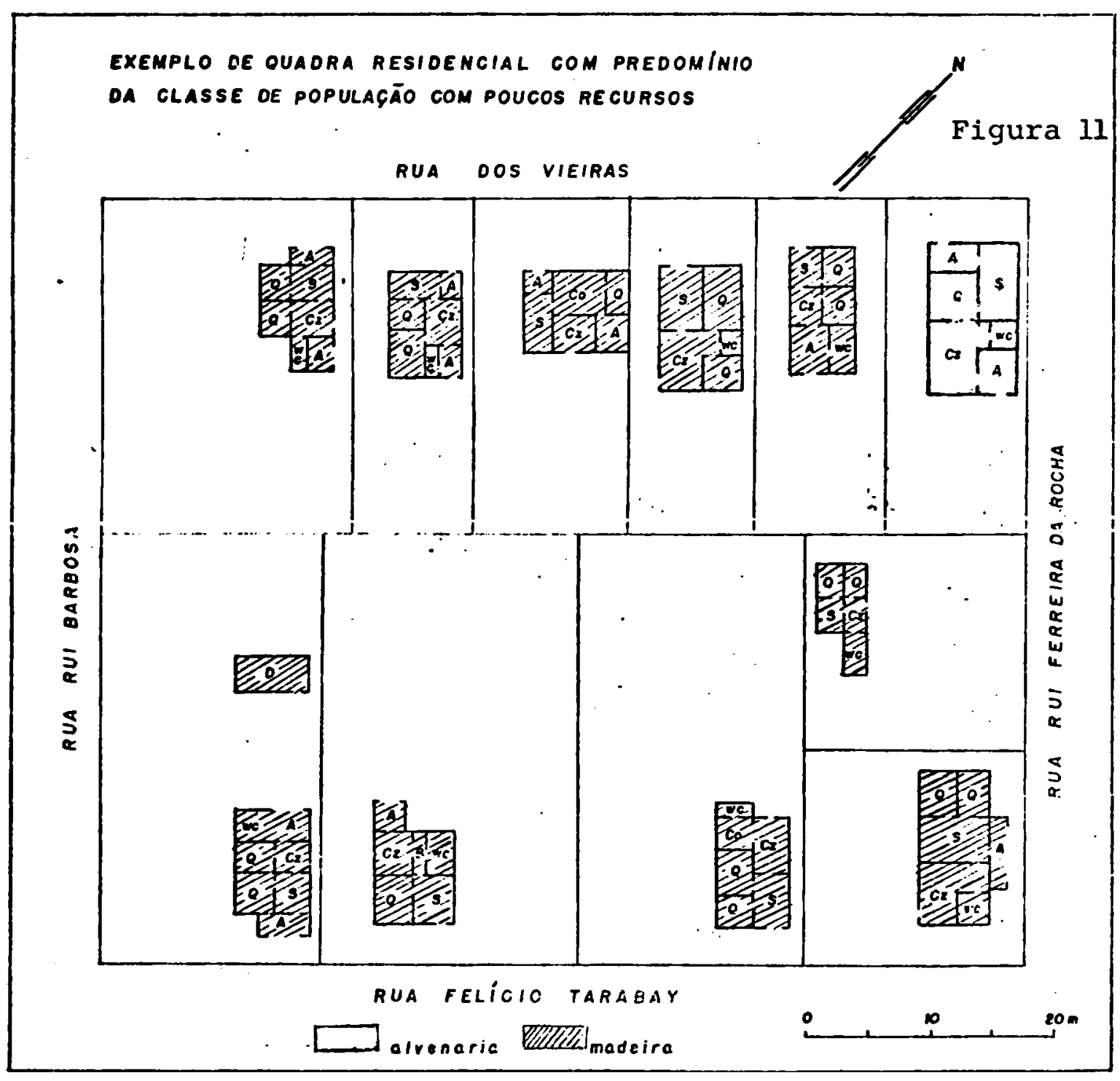


vindas da presença de fazendeiros, da projeção de alguns co merciantes e industriais e mesmo da melhoria do nivel salarial' de algumas atividades oficiais ou particulares e a idiferentes formas de financiamento.

Estes fatos modificam a concepção de dimensão dos terre nos e o estilo arquitetônico das construçōes. As edificações / são amplas, com plantas dentro de um conceito mais moderno e ra cional de aproveitamento, de acabamento mais fino, sem o exagê ro do luxo no seu sentido estrito, exigindo para tanto terrenos mais espaçosos, cujas medidas consideradas boas estão entre 15 a 20 metros de frente por 30 a 40 metros de fundo.

As construçõos voltadas para a produção industrial apre sentam-se de três formas: imóveis adaptados à nova função; imó veis com características de barracão e imóveis constrüídos com requisitos técnicos para o fim a que se destinam.

No primeiro caso são imóveis ligaḑos originariamente ao comērcio ou serviços, ocupando quase sempre todo o terreno, to mando a sua forma, e que se diluem na fisiononia da cidade; no segundo são imóveis voltados ao beneficiamento de cereais, in dústrias químicas e marmoraria, que ocupam parcela maior do ter reno onde foram edificados: com arguitetura gus so distingue! com razoável facilidade no conjunto urbano. No terceiro caso es tão os ịmóveis destinados ao beneficiamento de algodão, Fābrica. de óleos vegetais e as serrarias, constituindo os imóveis cons truídos com os requisitos técnicos necessários a estas indústri as e facilmente perceptiveis na morfologia urbana: os seus ter renos são bastante amplos e sua arquitetura própria, com variações que atendem às exigências das diferentes unidades da indús tria. Neste sentido a maior simplicidade e pobreza arquitetôn ca encontram-se nás serrarias.

Finalmente destacam-se do conjunto de imóveis urbanos, aqueles püblicos, que se caracterizam pelo seu estilo e padrão de construção, sendo bastante amplos e com terrenos espaçosos, cujos capitais empregados nas suas edificações são na maior par te externos: o Forum, Caixa Econômica Estadual, Bancos, Hospí tal, Centro de Saúde, Estabelecimentos Educacionais, Giñásio de Esportes, Igrejas, etc... 


\subsection{O Equipamento Público Urbano}

o equipamento público urbano constitui um conjunto de $\underline{e}$ lementos - ruas, praças, pavimentação, água, esgoto, ilumina ção - Integrantes do espaço citadino, com usufruto por toda a comunidade.

As ruas, espaços livres de uso coletivo, voltadas essen cialmente à circulação, tèm, em Paraguaçu Paulista, traçados qua se que essencialmente retilíneos e perpendiculares, face à for ma em tabuleiro de xadrez que a cidade possui. (Planta 1)

Entretanto, algumas delas apresentam quebra na monotonia da planta urbana em virtude de mudanças de direções e traçados, vinculados ao processo histórico da cldade ou aos loteamentos mais recentes.

o setor sul é portador das mais perceptiveis modificaçóes ao tabuleiro de xadrez do corpo principal da cidade.

Este setor é caracterizado pela presença de ruas com trá çados oblíquos, embora retilíneos.

Um primeiro conjunto é representado pelas ruas de dire ção leste-oeste a partir da rua Iepê. Ao que tudo indicạ esta

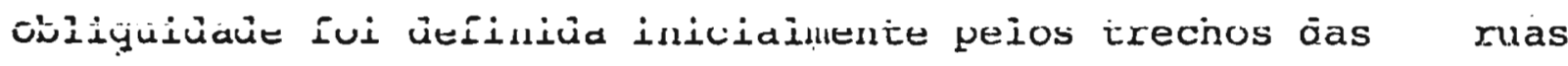
Iepê e Assis, abaixo da rua 7 de Setembro, tendo estas se cons tituído nas mais antigas saídas para a cidade de Assis. Recente mente, com a expansão do loteamento da Vila Atayde, acima da rua 7 de Setembro, aquelas ruas foram prolongadas com o traçado inicial, quebrando a perpendicularidade da planta da cidade nes te setor.

Contudo a grande modificação nesta face urbana é ovasion nada pelos traçados da Avenida Siqueira Campos e Rua Conceição de Monte Alegre.

Ambas são paralelas entre si, mas oblíquas em toda sua extensão ou $\mathrm{em}$ parte, à planta da cidade, sendo este aspecto mais perceptível para a Avenida Siqueira Campos.

A rua Concelção de Monte Alegre, mais antiga, constituiu nos primórdios da cidade parte do caminho que demandava ao nú cleo de Concelção de Monte Alegre. Posteriormente este caminho transferiu-se para um novo espaço traçado prolongando a Av. Si quira campos e paralelo ao anterior.

Estc prolongumcnto, quie atuulmente consititui parte dá citada avenida, norteou o loteamento da Vila Nova, que embora tendo ruas perpendiculares, no conjunto é desvinculada no espa 
co maior da cidade, e oblíquo a este.

Na Barra funda a quebra do traçado perpendicular das ruas é encontrado no primeiro trecho da rua José Salomão, à rua Monteiro Lobato, rua Paula Scuza, avenida Gago Coutinho e rua Borá.

A primeira quadra da José Salomão constituiu, na Barra Funda, o primeiro espaço público aberto na época da fundação da cidade, orientando-se para o caminho rural que conduzia à Fazen da Três Barras, outras propriedades rurais e posteriormente à Lutēcia.

o traçado deste trecho inicial definiu a rua Monteiro Lo bato, que the é paralela e possuidora, ainda hoje, de pequena parte daquele antigo caminho rural.

A avenida Gago Coutinho, ruas Paula Souza e Borá têm trạ çados oblíquos por terem sido abertas paralelamente à ferrovia, que de certa forma orientou o loteamento.nesta parte da cidade. Finalmente, a face norte apresenta un loteamento do tipo inglês (Jardim Panambi), com suas ruas formando anéis, cujas saídas se fazem pela avenida Galdino e rua Uruguai,constituindo a maior anomalia no conjunto urbano. Sua presença é recentíssi

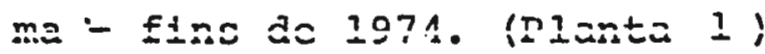

Dentro da sua organização, isto é, rede de vias que cons tituem na cidade, as ruas apresentam uma caracteristica funcio nal às vêzes ligada à circulação e à função dos imóveis que as bordejam.

Originariamente tiveram todas elas as mesmas possibilidą des de destaque, sendo largas e assentadas em um sítio ae extre ma suavidade.

Dentro do aspecto circulação, são mais favorecidas as avenidas Siqueira Campos, Paraguaçu, Gago Coutinho c rua 7 de Setembro.

Têm importância na rede viária urbana por constituirem saídas para outras cidade e zona rural. Entre elas o maior des taque cabe à Avenida Paraguaçu, que constitui a via principal da cidade, sendo tambēm a mais ampla, ligando-se na sua extremi dade oeste à rodovia asfaltada $\mathrm{SP}-284$ (50). Em segundo plano está a Siqueira Campos que liga a cidade à rodovia $\mathrm{SP}-284$ e à Raposo Tavares. Á partir da avenida Paraguaçu, é o trecho de mainr movimento de veículos na cidade.

(50) SP-284 Rodovia asfaltada 1 igando Assis-Paraguaçu Paulista -Quatā-Rancharia-Martinópolis. Apenas o último trecho não possui asfalto. 


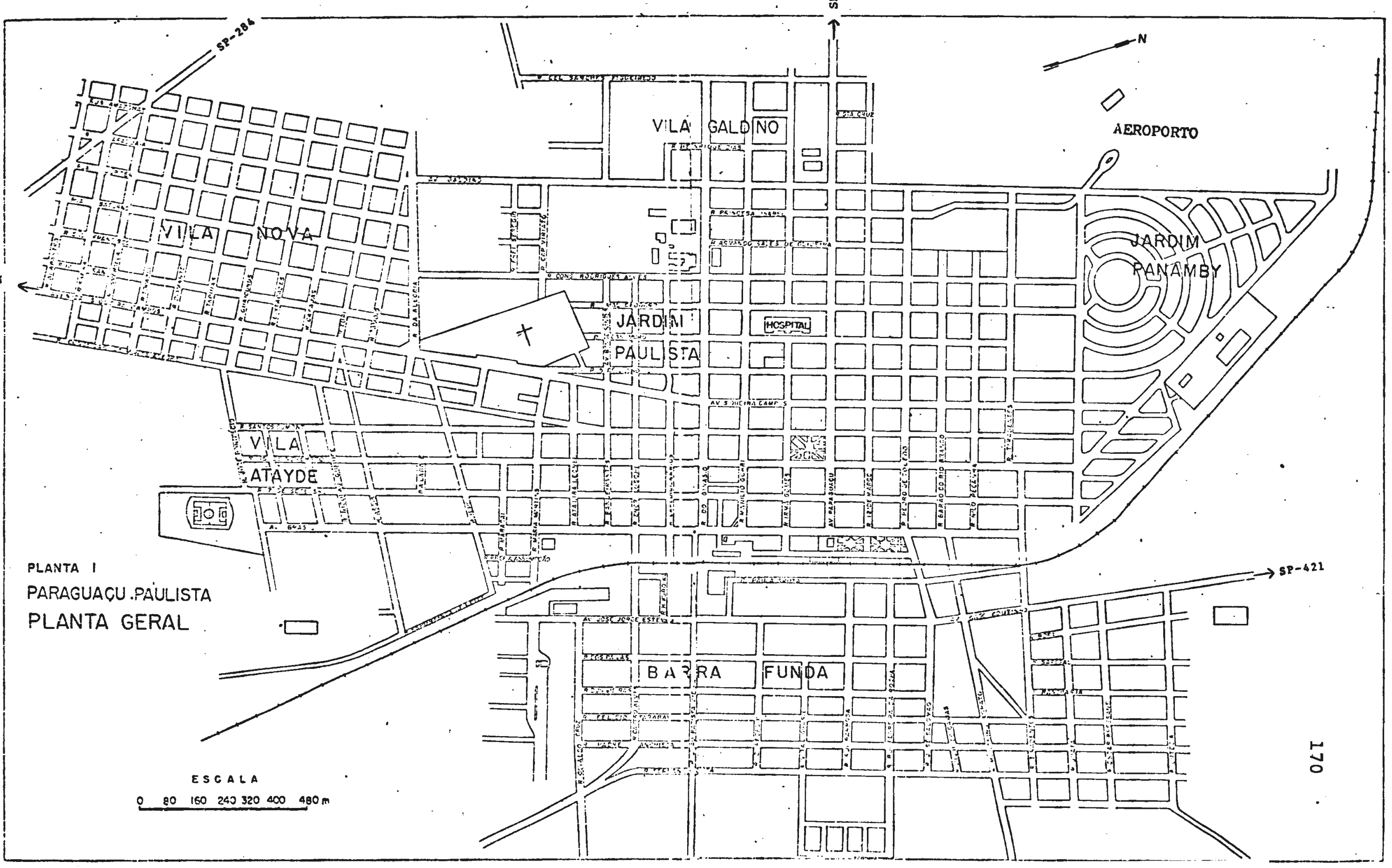


A avenida Gago Coutinho constitui a ligação entre o nú cleo urbano e o acesso que conduz ao município de Borá e a Rodô via $\operatorname{SP}-421$ ( 51 ).

Atualmente a 7 de Setembro perde gradualmente a sua $1 \underline{m}$ portância como saída para Assis. Foi, desde a abertura desta ro dovia, praticamente o seu ünico acesso, sendo que atualmente a circulação com este objetivo se transfere para a Avenida siquei ra Campos.

Completando o quadro de circulação, resta definir a im portância de partes de ruas que constituem passagem e ligação, de setores da cidade, por sobre a ferrovia. Estes trechos têm considerável importância por atraírem todo o fluxo de circula ção entre uma e outra parcela urbana.

A mais importante está nos primeiros trechos das ruas José Salomão, e Pedro de Toledo. Após esta temos os primeiros tre chos da Cistro Alves e Engenheiro Loschi e finalmente a passa gem existente na rua Tiradentes.

Ao lado deste aspecto de circulação, há trechos de ruas que se destacam pela presença de funções urbanas,principalmente do comércio e serviços.

A maior ımportāncıa verifica-se nos trechos das ruas que cortam a ārea central e estes são: Manilio Gobbi, Irmã Gomes , avenida.Paraguaçu, 12 de Março e Pedro de Toledo, entre a Avení da Brasil e a rua Santos Dumont; Santos Dumont, 15 de Novembro, 7 de Setembro e Avenida Brasil, entre a rua Manílio Gobbi e Pe dro de Toledo.

São trechos comerciais e de serviços, sendo mais valorí zados aqueles da rua 7 de Setembro e avenida Paraguaçu.

Servindo à função industrial, apenas as ruas Engenheiro Loschi, Castro Alves, Av. Jorge Esteves e rua Assis, tem relatí va importância, por constituirem as vias de acesso à fabrica de óleos vegetais e beneficiamento de algodão, sendo mais utilizá das pelos veículos pesados que àquelas demandam.

Por fim, dominàm as ruas servindo dominantemente espaços residenciais, ruas estas que têm fisionomia e importância comum na cidade.

As praças püblicas constituem os espaços voltados princí paimente ao lazeri, apresentando-se na cidade como jarảins ou

(5I) SP-421 Rodovia, em processo de asfaltamento, que liga a SP-284 à partir de Paraguaçu Paulista, a Lutécia, Oscar Bressane e Rodovia SP-333 Assis-Marilia. 
praças desportivas.

Os jardins encontram-se dispersos, possuindo quase sem pre a forma retangular ou quadrangular, face ao tipo de lotea mento dominante.

A praça mais antiga é a 9 de Julho, localizada entre a avenida Paraguaçu, ruas Santos Dumont, Irmã Gomes e XV de Novem bro, que ao lado das características de praça de "passeio" com põe o conjunto arquitetônico da Igreja principal da cidade. Sua origem data da fundação da cidade, através de doação feita pe lo proprietário das terras ocupadas pelo núcleo urbano. Bastan te cuidada, é cortada por uma série de alamedas que convergempa ra a porta principal da Igreja. Constitui o ponto de maior pro cura pela população para o lazer.

Ao seu lado, face sul, há a praça que serve o Centro Ad ministrativo onde estão o Forum, Caixa Econômica Estadual, Pos to de Fiscalização Estadual, Câmara Municipal, Agência do IBGE, Correio e Telégrafos. Apresenta um contorno ajardinado, sendo o centro arborizado, destinado ao estacionamento que serve es tas repartições. Além desta função, tem função política, pois, em um de seus lados (voltada para a rua Irmã Gomes) è utilizada para as manifestaçöes e comemoraçöes cívicas. Sua definição è recente - pouco menos de 10 anos - téndo constituido a sua área central oficina de reparos e garagem da Prefeitura Municipal.

A frente da estação ferroviāria encontra-se a maior e mais recente praça pública.

originariamente resumia-se ao prolongamento da avenida Paraguaçu, abaixo da avenida Brasil, cujas laterais eram ocupa das por alguns canteiros arborizados. Além, para um lado e ou tro, havia residências de ferroviários e apōs estas, em direção à rua Pedro de Toledo, o espaço era ocupado pelo "pateo de to ras" para embarque pela ferrovia.

Apōs 1958, através de sucessivas desapropriações e com a colaboração da colônia japonesa, chegou-se à sua forma atual: amplo espaço ajardinado e destacando-se no centro a fonte lumi nosa sonora e no extremo norte, um conjunto em estilo oriental japonès. A praça estende-se desde a altura do Mercado Municipal à rua Pedro de Toledo, por mais de 400 metros, embora seja cor tada pelas ruas Irmã Gomes e 12 de Março.

Constitui uma praça de "passeio".

Alēm destas há pequenos espaços fronteiros às igrejas da Barra Funda e Nossa Senhora Aparecida na Vila Affine, a praça 
entre a avenida Siqueira Campos, Santos Dumont e Engenheiro Los chi e o jardim do cemitērio.

Os primeiros são pouco cuidados, sem ajardinamento, ser vindo apenas de acesso às igrejas. o segundo espaço é todo arbo rizado, gramado, voltado ao descanso e constituindo um "ponto" de espera de ônibus e conduções que demandam a Assis, Conceição de Monte Alegre ou em direção à Raposo Tavares.

Finalmente, o espaço frente ao cemitério: todo arboriza do, gramado, possuindo um vaso luminoso. Sua função é exclusivamente de embelezamento à necrópole.

Estas duas ūltimas praças tèm a forma triangular.

Como praças esportivas há na cidade a quadra de esportes "Elzinha" e o Estadio Municipal Carlos Affine.

A primeira constitui um espaço de esquina entre as ruas Nilo Peçanha e Siqueira Campos, ocupado por uma quadra para es portes de salão. Sua presença é provisóría, enquanto aguarda-se o término das obras do Ginásio de Esportes, que encontra-se à sua frente, na esquina oposta.

- Estādio Municipal, localizado nos extremos da Avenida Brasil e rua 7 de setembro, foi, durante muito tempo, utilizado apenas para a prática do futebol e atletismo, tendo, a partir dos últimos 5 anos, somada a função de sede e local da feira agro-pecuária anual do município.

Aproximadamente $38 \%$ das ruas da cidade são pavimentadas, sendo $338 \mathrm{com}$ asfalto e 58 em "blokret", havendo como complementa ção alguns trechos de ruas que foram empedradas. (Planta 2)

Este equipamento urbano tem início de sua implantação por volta de 1951/52, na quadra da rua 7 de setembro entre a rua 12 de Março e avenida Paraguaçu na primeira etapa, feita com lajotas de concreto (blokret), toda a ārea central, beneficiando diretamente a área de comércio e serviços.

Após 1955/56 o capeamento das ruas passou a ser feito por asfalto que, na.sua expansão inicial, cobriu toda a periferia do centro e orientando-se, além desta, para os setores de maior densidade de construções, fator que atualmente norteia os proje tos de ampliação deste serviço.

Além do fato densidade construía, foram observadas as condições sócio-econômicas da população e o atendimento à circu lação na implantação do equipamento. Estes aspectos podem ser ob servados na Barra Funda, onde a densidade das construções, em boa parte do conjunto, pressupōe a presença do equipamento, mas 
este existe nos eixos principais de circulação, na sua pequena ărea comercial ou onde hã população. economicamente melhor aquí nhoada.

Visando a conservação das ruas e, por complemento, servin do a circulação, 3,28 das ruas são "empedradas", sendo a maior parte em ruas da Barra Funda. (Planta 2)

o sistema de abastecimento de água existente em Paraguaçu Paulista, foi implantado a partir de 1951.

o manancial utilizado neste sistema é o Ribeirão Alegre, a leste da cldade, com vazão da ordem de $1,2 \mathrm{~m}^{3} /$ segundo, cujo curso dista aproximadamente 2.700 metros da estação de tratamen to localizada nos "altos do centro urbano", no início da rua Armando Salles de oliveira,

Segundo a relação fornecida pela Prefeitura Municipal (maio de 1972), a distribuição de āgua é feita através da rede com 42.630 metros de extensão e 2.866 ligações. Considerando-se a média de 4,6 habitantes por domicílio na cidade, tem-se apro ximadamente 13.100 habitantes servidos, o que significa mais de 958 da população urbana. (Planta 3 ).

Embora abrangendo quase toda a cidade, com manacial sufi ciente para atender 'a demanda, pelás informaçōes obtidas, o sis tema apresenta problemas relacionados ao dimensionamento e à idade do material existente, principalmente na adução, captação e tratamento.

Face a isto, a Prefeitura Municipal volta suas atenções para o aproveltamento do poço estratigräfico perfurado pela Pe trobrás, nas proximidades oeste da cidade, por volta de 1961/62 Em 1971 a Prefeitura contratou os serviços do I.G.G. para as obras de limpeza do referido poço com intuito de explorar a sua água para abastecimento público o que, de certa forma, ali viará em bastante o serviço existente atualmente, pois a vazão é de $113 \mathrm{~m}^{3} /$ hora de água praticamente pronta para o consumo.

A cidade é servida por rede de esgotos que tem a sua im plantação concomitante à do sistema de abastecimento de água.

Os dejetos captados por esta rede são lançados, sem trá tamento, no Ribeirão Alegre a aproximadamente 1.500 metros abai xo do local de captação da àgua.

A rede coletora, tem aproximadamente 39.000 metros de extensão e cerca de 2.350 ligações, significando, tace à mẻdia de habitantes por domicilio em torno de 4,6 um atendimento de aproximadamente 808 da população urbana. Contudo há, sem que se 
possa no momento defini-los quantitativamente, um número de do micílios que embora possuindo rede de esgoto na rua, não são a ele ligados.

No conjunto urbano apenas a periferia, inclusive grande parcela da Barra Funda, não possui este equipamento. (Planta). Atualmente um problema se propõe à administração municí pal o transbordamento da cidade em direção ao vale do Sapé (Vi la Galdino e parte do Jardim Paulista) mudando a direção da de clividade, tornando bastante difícil a expansão da rede para es te setor do espaço urbano. 


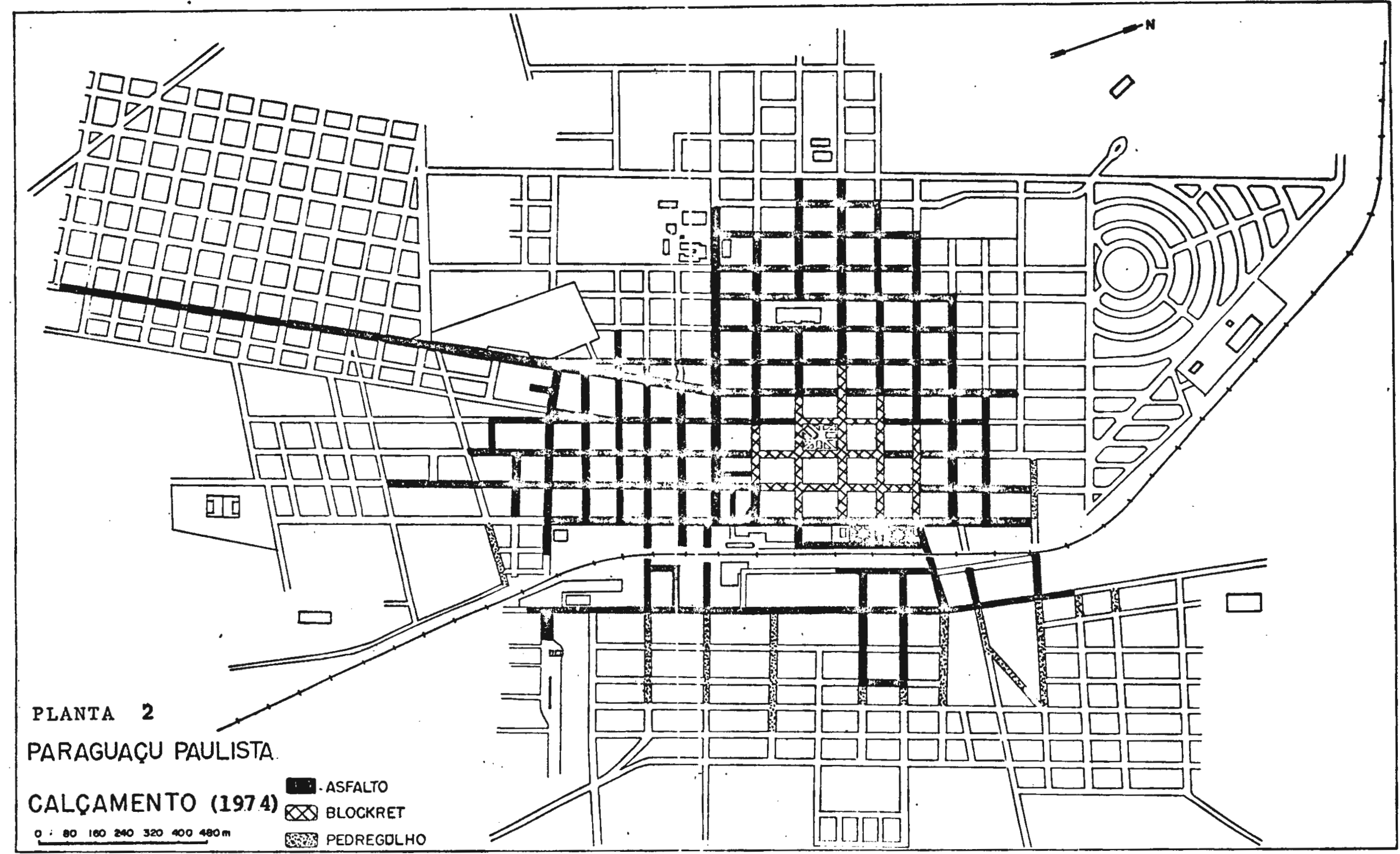




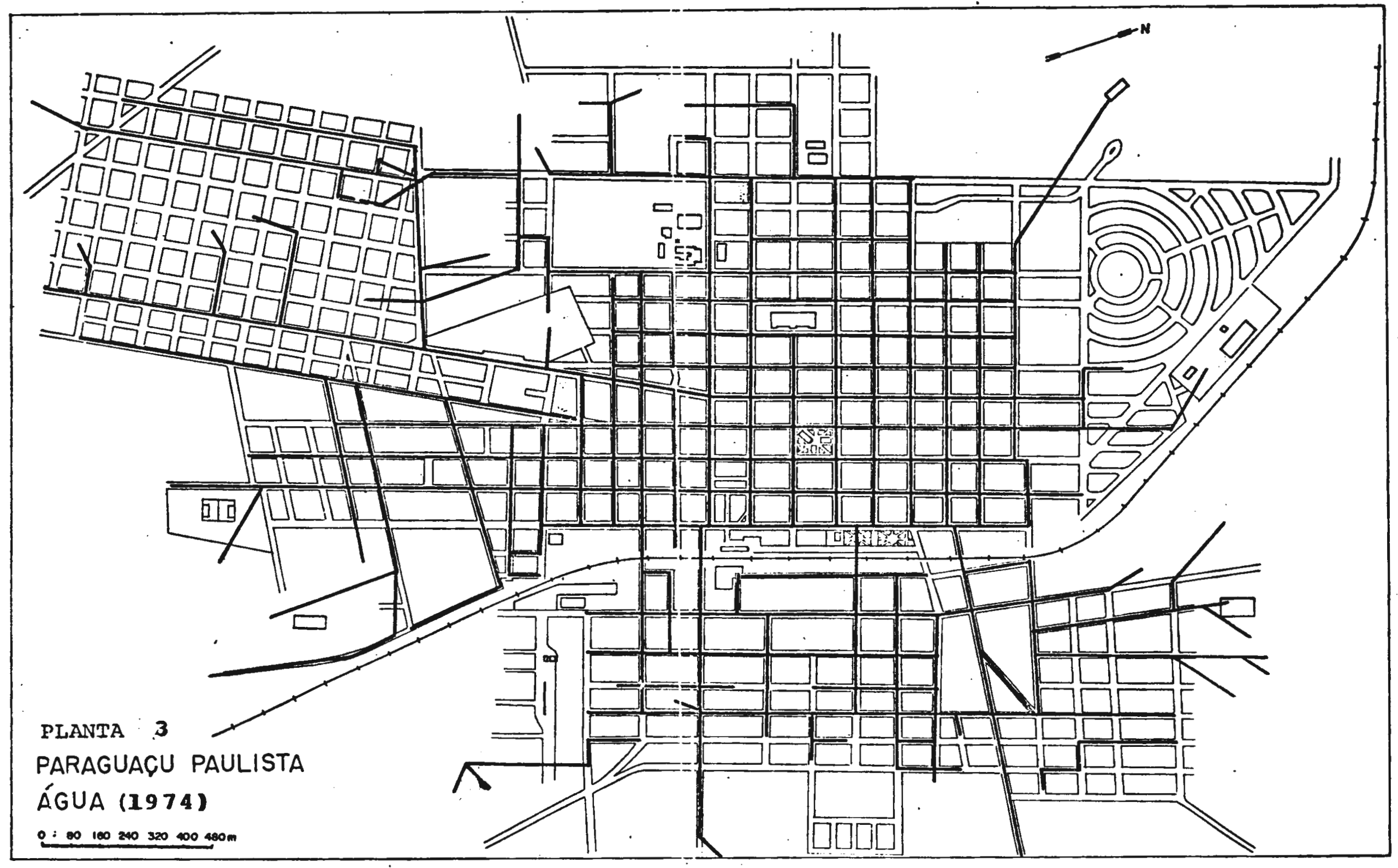




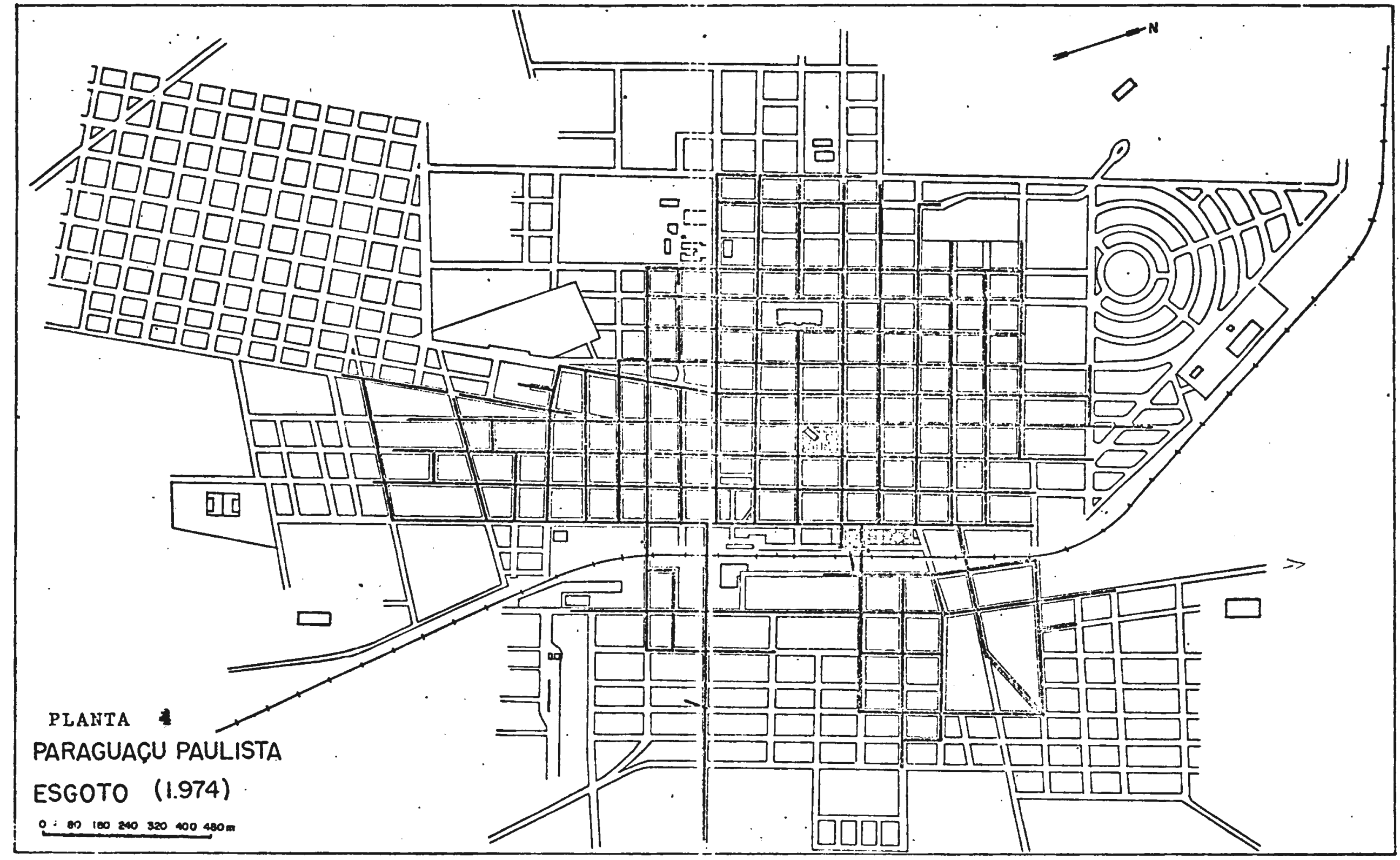




\subsection{Espaço Livre, Espaço Construido e População}

- espaço ocupado pela cidade é de aproximadamente $4.800 .000 \mathrm{~m}^{2}$, onde as ruas cobrem 8,958; às áreas vazias, isto é, sem qualquer edificação, 34,178 e os terrenos que possuem edifi caçōes $46,88 \%$. Neste espaço urbano total, as áreas destinadas ao lazer - jardins, logradouros públicos, praças esportivas -ocupam apenas 2,088 e as āreas edificadas somam 7,65\%.

Estes fatos e os que seguem podem ser vistos em detalhe através da tabela 33 e planta 5 .

Abrigando uma população urbana de 13.331 habitantes (Cen so de 1970), o espaço total da cidade apresenta uma relação de 1 habitante para $360 \cdot \mathrm{m}^{2}$. Excetuando-se a área das ruas ( 1 habitan te para $68,3 \mathrm{~m}^{2}$ de rua) e destinadas ao lazer ( 1 habitante para $7,5 \mathrm{~m}^{2}$ de ārea de lazer), esta relação passa a ser de 1 habitan te para $284,3 \mathrm{~m}^{2}$.

Considerando-se os espaços com edificações tem-se uma rela ção de $1 \mathrm{~m}^{2}$ de ārea construída para $6,1 \mathrm{~m}^{2}$ de terreno. Por outró lado, as relações entre estes espaços e a população urbana são muito mais amplas: 1 habitante para $27,6 \mathrm{~m}^{2}$ construido e 1 habi tante para $168,8 \mathrm{~m}^{2}$ de terreno com edificação: inclusivé esta.

Os terrenos vazios, isto è, terrenos sem qualquer edifica ção, apresentam, dentro do quadro urbano, uma relação de 1 habi tante para $123,1 \mathrm{~m}^{2}$.

Entretanto, segundo o fim a que se destinam e tipo de mate rial utilizado nas construções, verifica-se variações nestas re lações.

Os imóveis para fins residenciais ocupam $68,65 \%$ dos terre nos que possuem edificações e as suas edificações representam $63,53 \%$ da área construída total. Esta ocupação nos dá uma relação de $1 \mathrm{~m}^{2}$ construido para $6,6 \mathrm{~m}^{2}$ de terreno e uma densidade demo grāfica urbana mais real: 1 hab/17,5 $\mathrm{m}^{2}$ construído e 1 hab/115,9 $\mathrm{m}^{2}$ de terreno. Quanto ao material utilizado, tem-se certo equíli brio entre a área edificada em alvenaria e em madeira, com pre sença pequena das construções mistas $(6,2 \%)$. Contudo os terrenos ocupados pelas residências em madeira constituem quase $70 \%$ da a rea dos terrenos residenciais, restando à alvenaria pouco mais de 268 e às mistas 48 .

o comércio e serviços têm 27,648 da ārea dos terrenos que possuem edificações e $21,45 q$ da ärea construída, significando ${ }^{2} \mathrm{~m}^{2}$ construído para $4,7 \mathrm{~m}^{2}$ de terreno. Neste setor de atividades há amplo predomínio das construções em alvenaria, com pequena pre- 
sença dos edifícios mistos e quase nula daqueles em madeira. Con seqüentemente os terrenos obedecem a mesma participação, sendo pouco mais espaçosos aqueles ocupados pelas construções mistas.

o setor industrial ocupa o menor espaço e possui a menor área construida, mas dispõe de maior relação espaço construído / espaço livre: 8,838 dos terrenos que possuem edificações, 9,90\% da ārea construida e uma relação de $1 \mathrm{~m}^{2}$ construido/6,9 $\mathrm{m}^{2}$ de terreno. (Tabela 33)

Com referência ao material utilizado, o aspecto se pro põe de maneira semelhante ao comércio e serviços: predomínio da alvenaria tanto em ārea construída quanto dos terrenos que ocu pạm seguida da madeira, esta bem mais realçadà em relação à atị vidade anterior e finalmente, as construções mistas.

Utilizando-se a divisão setorial do I.B.G.E., para o Cen so de 1970, observa-se que o espaço construído é mais denso no conjunto formado pelos setores $1,2,3 \mathrm{e}^{-4}$.

Eśte conjunto setorial tem $51,99 \%$ da área urbana edificada sobre apenas 33,588 dos terrenos urbanos com construção. ' A relação espaço construído/espaço livre confirma estes fatos: $1 \mathrm{~m}^{2}$ construido/3,9 $\mathrm{m}^{2}$ de terreno.

Considerando-se cada setor, esta densidade é marcante nos setores 1 e 3, cujas relações área construída e terreno são da ordem de $1 \mathrm{~m}^{2} / 2,1 \mathrm{~m}^{2}$ e $1 \mathrm{~m}^{2} / 2,7 \mathrm{~m}^{2}$, respectivamente. 0 setor 2 apro xima-se da média, sendo o 4 portador de terrenos mais amplos.

Nestes setores a predominância do espaço edificado defí ne-se para a função residencial, exceto nos setores 1 e 3 , onde - comércio e serviços têm grande presença, fato mais caracteriza do no primeiro deles. Não deve ser negligenciada a área industrí al, pois a sua presença corresponde a pouco mais de $26 \%$ do total da área industrial urbana, embora ocupando menos de 98 dos terre nos para o mesmo fim.

Quanto ao material utilizado nas construções, a alvenaria è predominante, não só pela ārea edificada mas pelo espaço terrị torial livre que possue, havendo neste último aspecto, exceção ao setor 2 onde os terrenos pertencentes às edificações em madeira são mais amplos.

Ainda com relação ao material utilizado, observa-se que as relações espaço construído/espaço livre são bastante reduzidos no que toca à alvenaria, mais folgados nas áreas ocupadas pela ma deira e construções mistas. No .conjunto o setor 4 foge completamente a estas características, dispondo as construções de gran 
des espaços o que muda muito a relação entre o espaço edificado e o espaço livre.

As densidades demográficas encontradas são as mais baí xas da cidade, considerando-se apenas as āreas construídas para fim residencial e respectivos terrenos. Apenas o setor 4 tem ra zoável densidade, o que pode ser explicado pela presença de um grande nūmero de construções relativamente pequenas antecedendo a fase atual a qual apresenta casas mais amplas e terrenos mais espaçosos, como jā se viu anteriormente.

Os demais setores, 6 a 10, tem $48,0 \%$ da ärea edificada e $66,41 \%$ dos espaços que contêm construções, trazendo para o con junto a relação de $1 \mathrm{~m}^{2} \mathrm{C} / 8,5 \mathrm{~m}^{2} \mathrm{~T}$. ( $C=$ construído; $\mathrm{T}=$ terreno)

Considerando-se os diferentes setores do conjunto, os mais densos em área edificada correspondem ao 5,7 e 8 , onde as relações são: $1 \mathrm{~m}^{2 \mathrm{C} / 7}, 1 \mathrm{~m}^{2} \mathrm{~T}, 1 \mathrm{~m}^{2 \mathrm{C}} / 6,5 \mathrm{~m}^{2} \mathrm{~T}$ e $1 \mathrm{~m}^{2} \mathrm{C} / 5,2 \mathrm{~m}^{2} \mathrm{~T}$, respectivamente. A menor densidade é encontrada no setor 10 , onde esta relação é de $1 \mathrm{~m}^{2} \mathrm{C} / 5,2 \mathrm{~m}^{2} \mathrm{~T}$.

Esta maior ou menor densidade deve-se não só à área que - espaço edificado apresenta, mas principalmente ao espaço li vre de que estes dispõe. Assim, o setor 7 apresenta boa densida de construida porque a área dos terrenos portadores de edifica ções é pequena, enquanto que o setọ 9 , com uma das menores den sidades construída, tem no espaço edificado área bem maior que aquela do setor 7 , sendo, entretanto, bastante ampla a sua área territorial livre.

Neste setor verifica-se a predominância da área construí da para a função residencial, seguida pelo comércio e serviços (comércio nos setores 6 e 7 e serviços nos setores 5,8 e 10). A área industrial concentra-se nos setores 8 e 9, correspondendo a área construida a mais de $62,0 \%$ da ārea industrial urbana, sōbre mais de $77 \%$ dos terrenos utilizados para o mesmo fim.

Os grandes espaços livres estão vinculados às constrú ções residenciais e de madeira, exceto nos setores 8 e 9 onde os serviços e a indústria detêm parcela razoável destes. 0 se tor 9 apresenta amplos espaços ocupados pelo Almoxarifado da Prefeitura Municipal, Delegacia de Polícia, Estādio Municipal e pela Cia. SAND., ligada ao beneficiamento de algodão, no setor 8 o grande espaço livre está vinculado à fábrica de óleos vege tais da Anderson \& Clayton.

Quanto ao material utilizado, hā predominância da ārea construída em alvenaria, com maior parcela destinada ao uso do 
comércio e serviços. Entretanto, o conjunto espacial livre que a serve é bastante inferior àquela de madeira, como se viu aci ma.

Desta forma, verifica-se que as relações espaço constrú do/espaço livre são bastante reduzidos na alvenaria, quando com parados àquela para as construções em madeira, exceto no setor 8, onde a área livre destinada à alvenaria è duas vezes àquela destinada às construções em madeira, fato justificado pela pre sença dos estabelecimentos püblicos e industriais, que exigem grandes espaços.

Tomando-se cada setor e suas respectivas áreas construí das, tem-se um predomínio do espaço ocupado pela madeira nos se tores 5,6 e 10, enquanto que a alvenaria prepondera nos demais. Um aspecto a ser observado é o de que em nenhum dos setores em questão, a ārea total em alvenaria é maior que aquela em madei ra, quando se destina ao uso residencial..

A. construção mista tem neste conjunto setorial menor ex pressão que no conjunto anterior. A sua participação por setor é pequena, e definida em mais de $80 \%$ nos setores $5,8,9$ e 10 . tanto no ponto de vista das edificações quanto dos seus espaços livres, scndo o fim rosidoncial dominante mais ale $70 \%$.

As densidades demogräficas são as mais altas da cidade, tomando-se os espaços construídos para residências e seus terre nos.

Considerando-se as relações habitante/espaço construído e habitante/espaço livre, verifica-se que as construções residen ciais são pequenas enquanto que os seus terrenos são amplos.

Tomando-se a primeira relação, os setores 9 e 10 são me nos densos populacionamente, isto porque parte destes setores são contíguos aos setores centrais, demonstrando a presença de residências mais espaçosas. Em contrapartida, a relação habitan te/espaço livre mostra os mais altos índices de toda a cidade, isto porque na face externa destes setores muitas residencias constituem uma ilha de pequena ārea construída em meio a imenso espaço livre que the pertence. Este fato é mais comum nos lotea mentos da Vila Atayde e Vila Nova. 


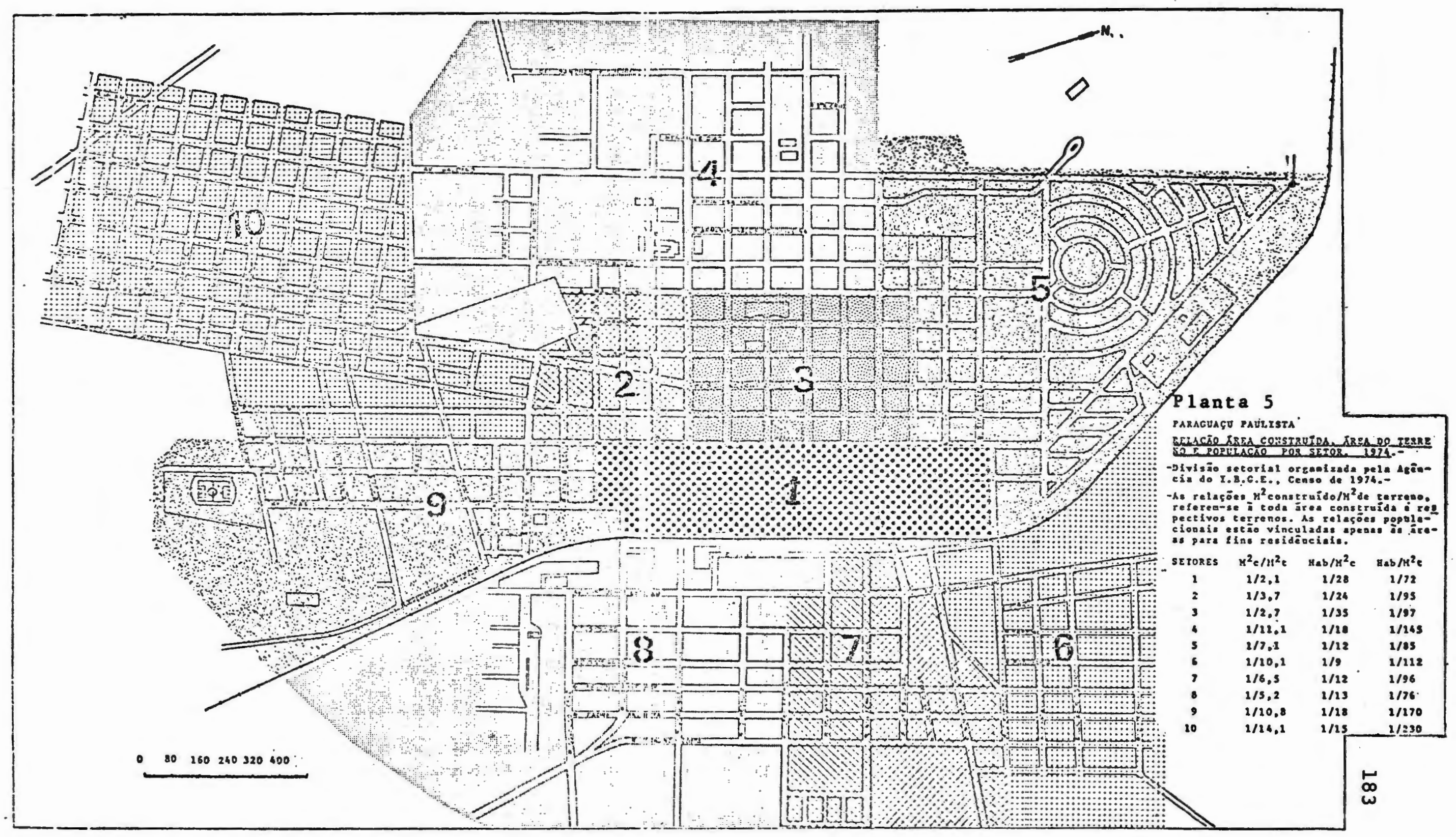


SETOR 6

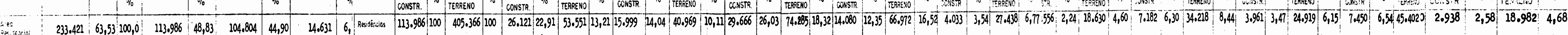

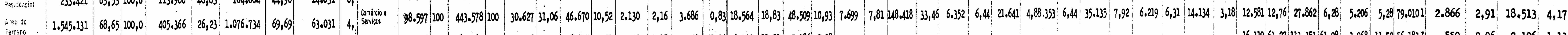

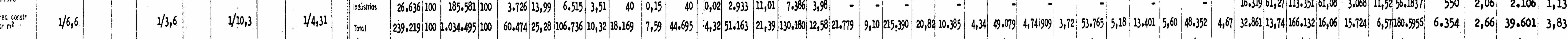

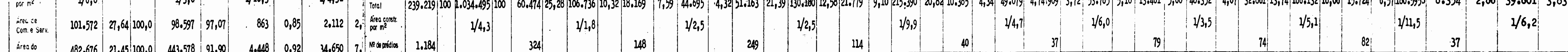

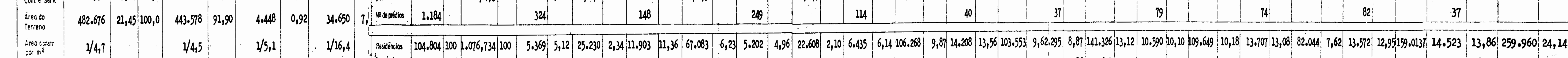

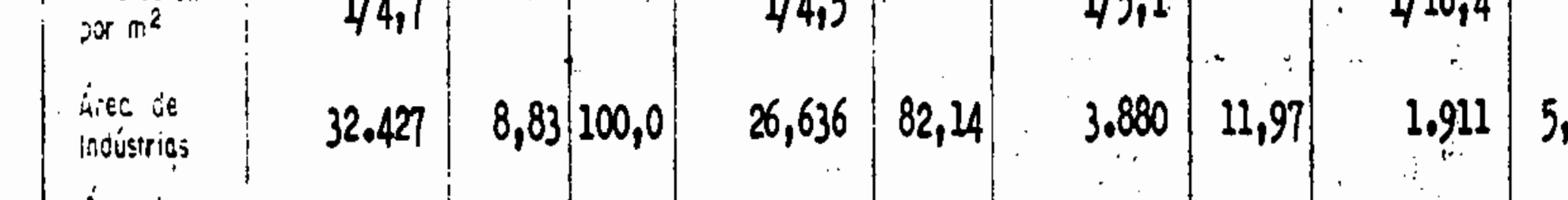

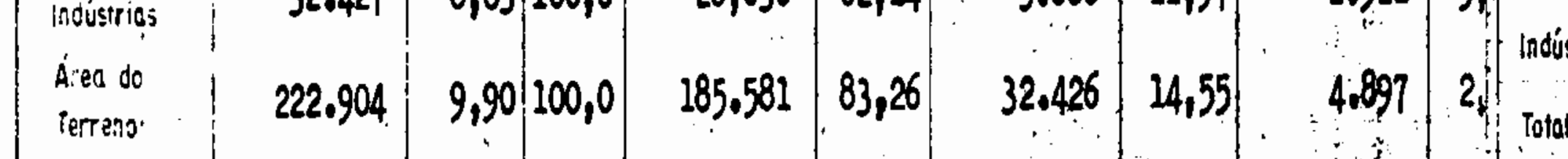

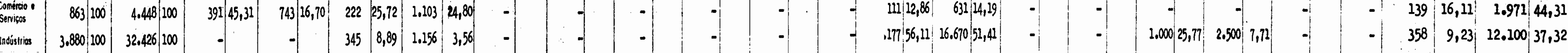

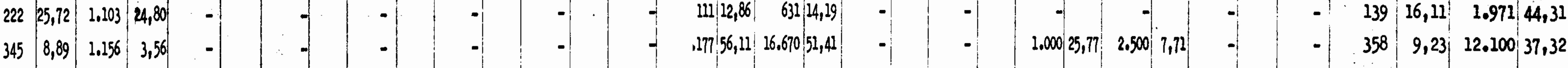

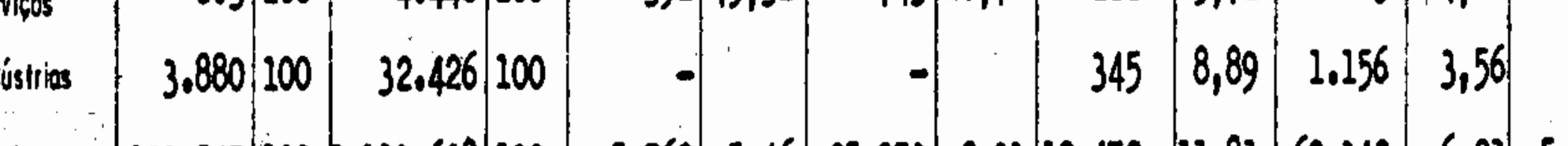

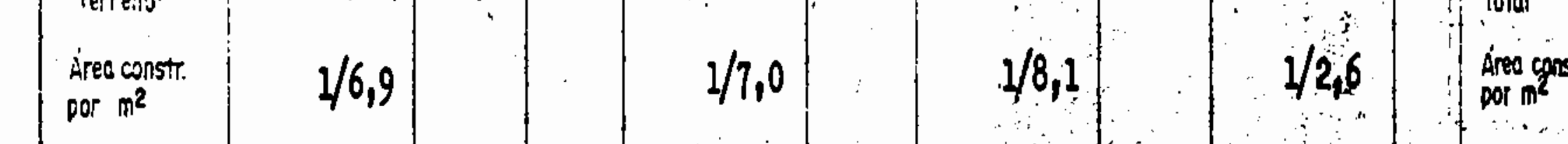

$2 / 10,2$

$4.8000000 \mathrm{~m}^{2}-1$ hab $/ 360$,

Irea aproxinadaida cidade

Area dos terrenós coo edificicaşōes

年

Area dos terrenoss vazios $2.545 .131 \mathrm{~m}^{2}-1 \mathrm{hab} / 115$,
$1.640 .883 \mathrm{~m}^{2}-1 \mathrm{hab} / 123$

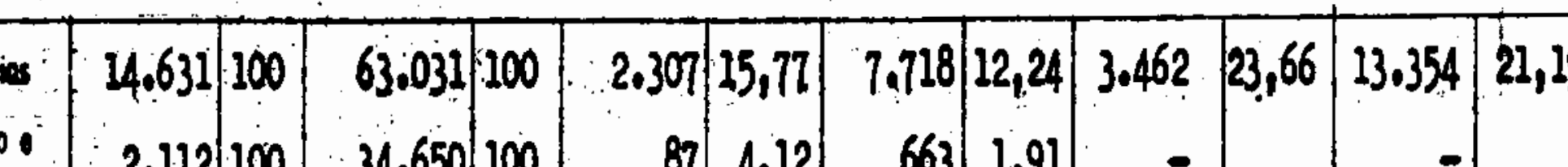

$\begin{array}{lllllllll}2.112 & 100 & 34.650 & 100 & 87 & 4,12 & 663 & 1,91\end{array}$

$1.911100 \quad 4.897100 \quad 1.911200,00 \quad 4.897100,00$

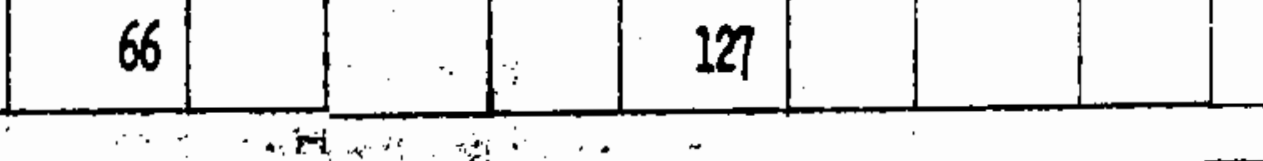

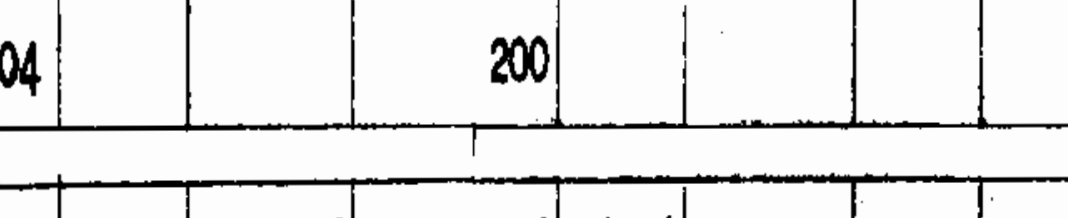

ant

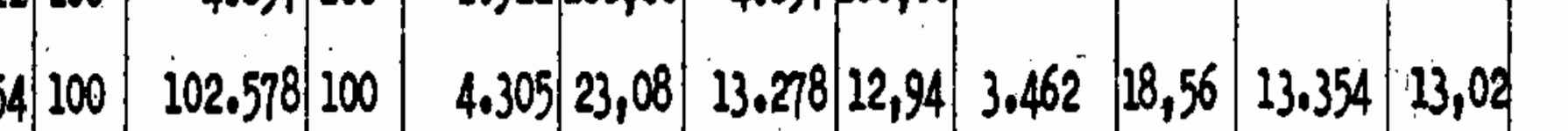

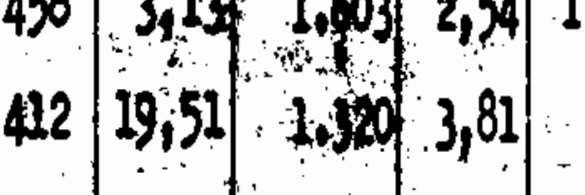

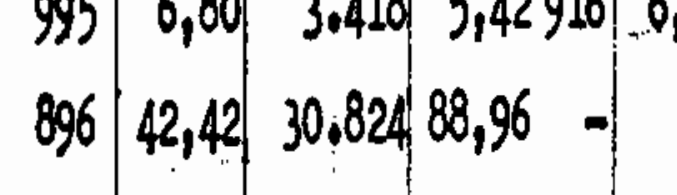
$1 / 3,9$

$\begin{array}{llllll}870 & 4,66 & 2,923 & 2,85 & 1.013\end{array}$

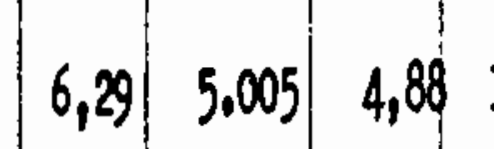

$$
-1 \text { - }
$$

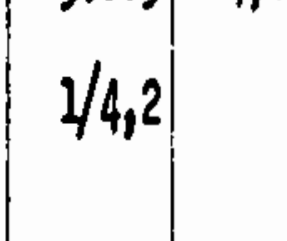

$2 / 18$,

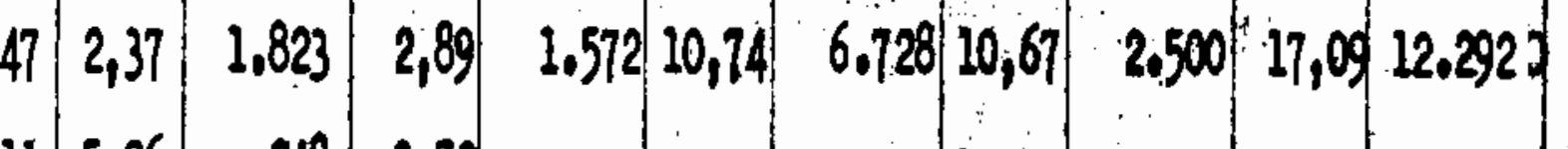

241

Area construida

$910.000 \mathrm{~m}^{2}-1 \mathrm{hab} / 68$,
$100.000 \mathrm{~m}^{2}-1 \mathrm{hab} / 7$,
$367.420 \mathrm{~m}^{2}-1 \mathrm{hab} / 27$,
$233.241 \mathrm{~m}^{2}-1 \mathrm{hab} / 17$,

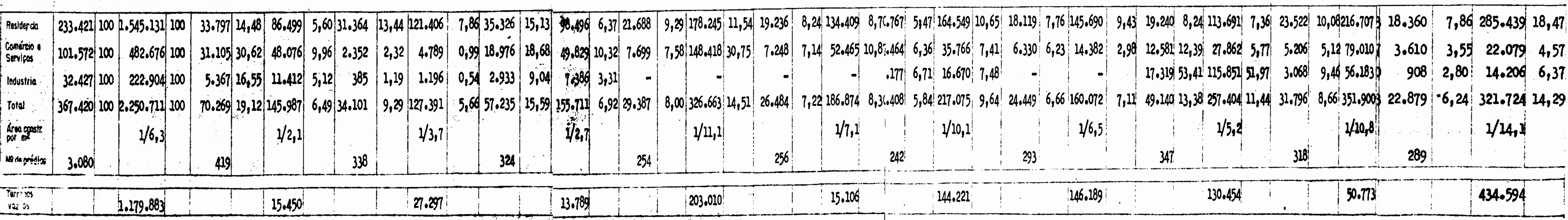




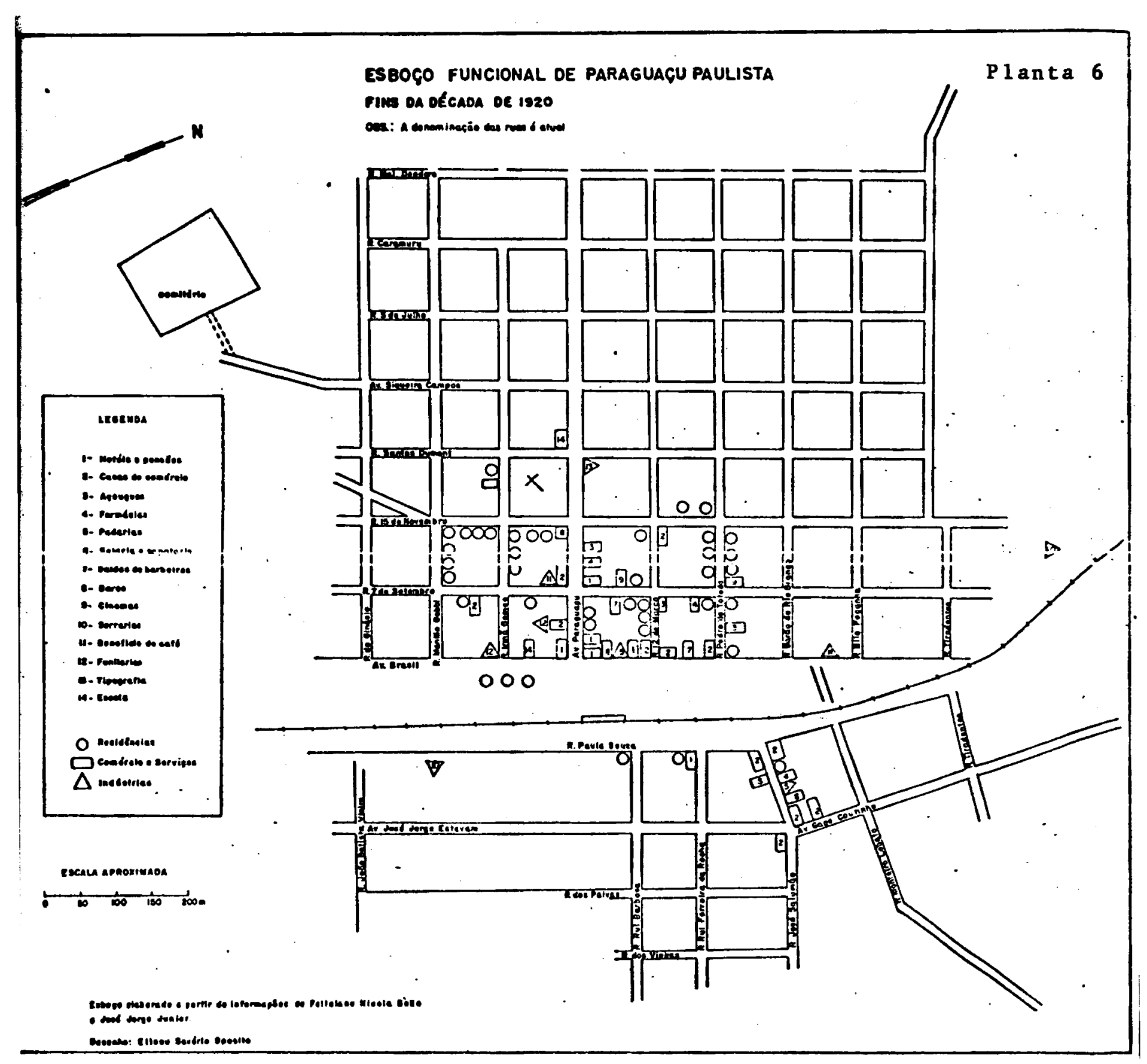


Nesta primeira fase da expansão urbana, os primeiros ele mentos dos diferentes setores de atividades jā se faziam presen tes.

A atividade industrial, de um lado ligada a produção rú ral, se vê representada pelas primeiras serrarias, localizadas em ambós os lados da ferrovia, e pelo beneficiamento do arroz e café, esta com uma posição mais central face a atividade comer cial que seu proprietário exercia na época. De outro lado a ati vidade industrial voltada para as necessidades urbanas, repre sentadas pelas padarias, tipografias e funflaria, disseminadas pelo centro da cidade.

As atividades de comércio e serviços, dispostas na sua maioria ao longo das atuais avenidas Brasil e rua José Salomão, somavam de 30 a 40 estabelecimentos, predominando as lojas ou armazéns, os hotéis e pensões. Ao lado destes os açougues, far mācias, selariaś e sapatarias, bares, cinemas, salões de barbei ro, escola, igreja, completavam o conjunto destas atividades.

Complementando o quadro, embora sem possibilidades de de fini-los espacialmente e numericamente, havia as residências que pelas informações obtidas, apresentavam-se de forma mista aos

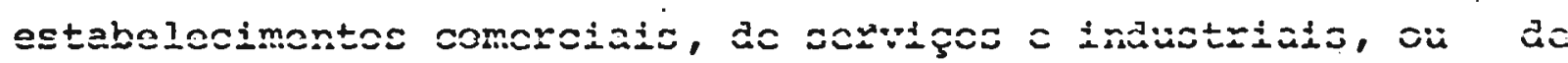
forma independente, mais rarefeitas, dentro dos limites já fixa dos.

Nesta fase a economia do município voltava-se para ativi dades criatórias ao lado da qual iniciou-se a cafeicultura re sultando, conseqüentemente, na abertura e ocupação das terras e aproveitamento das matas. Estes fatos dinamizam o espaço urbano e rural, ativando a fixação, formação e crescimento da popula ção.

Na segunda fase, entre o final da década de 1920 e iní cio da década de 1940, o espaço urbano apresenta significativa expansão e ocupação.

o quadro esboçado inicialmente amplia-se e seus limites, passam a ser delineados pelas atuais ruas Marechal Deodoro, Tí radentes, trechos da Felíclo Tarabay, Rui Barbosa, avenida José Jorge Esteves e rua do Ginásio.

o desenvolvimento dos setores de atividades alteram o quadro inficial, através de um razoável adensamento e pequena am pllação do mesmo, senco que esta se define apenas peía mudança dos seus limites da atual rua 15 de Novembro para a Santos Du mont e para as atuais José Jorge Esteves e Gago Coutinho, nas 
suas primeiras quadras, partindo-se da José Salomão. (Planta 7 )

o malor crescimento e ocupação cabe ao terciārio de . co mércio. Quase ao final desta fase (1938), este setor somava mais de 100 estabelecimentos, concentrados na sua quase totalidade no quadro delineado acima. A sua predominância uma vez mais é ca racterizada pelos secos e molhados, lojas com comércio de fazen das e artigos variados ao lado de uma boa presença dos bares e botequins.

- terciārio de serviços acompanha-o neste desenvolvimento, ampliando o campo de suas atividades com a presença de médi cos, dentistas, advogados, tinturarias, alfaiatarias, oficinas de consertos, etc., cabendo, entretanto, aos hotēis e pensōes o maior número seguido pelas barbearias. Ao final do ano de 1938 o número de estabelecimentos e atividades de serviço era supe rior a 50 .

A atividade industrial que cresceu mais em função das ne cessidades urbanas (padarias, marcenarias, serralherias, funila rias)tem, embora em nümero restrito, mais expressão naquelas li gadas ao desenvolvimento do café e algodão. A primeira cultura dá origem a mais três máquinas de beneficiamento do produto, en quăinto quie à seyuncia viferce cunuiçũes pala as primeiras instä lações de beneficiamento $(1935 / 35)$. Estas atividades industrí ais não.apresentam concentração ou preferêncla no nūcleo urbano, mas guardam os limites $j a ́$ assinalados para o espaço citadino.Cá be apenas lembrar que os beneficiamentos de algodão se colocam ao lado da ferłovia, nos dois extremos da cldade, cortada por esta.

A função residencial apresenta-se bastante desenvolvida com adensamento junto ao centro (imóveis mistos) e periferia,ra refazendo-se na medida que se afasta destes. Entretanto, è o quadro residencial que define os limites e ampliação do espaço urbano.

Esta etapa de expansão do espaço urbano deriva-se do de senvolvimento da cultura cafeeira, iniciada na fase anterior, e da cultura do algodão, que è mais significativa nos fins da dẹ cada de 1930, início da década de 1940. (Cap.3.1.)

Economicamente mais marcantes que aquelas atividades da fase anterior, estas culturas abrem e povoam os espaços rurais gue por relação direta afctam o contro urbano quic lhos a fontc de abastecimento, comercialização, serviços e transformação de produtos.

Este conjunto de aspectos ativam o proces 
so populacional em fase de formação e fixação, tanto rural quan to urbano. No tocante à cidade esta população cresce em mais de 768 em um período de 6 anos (1934 a 1940), (Cap.4.1.) refletindo-se diretamente na expansão e ocupação de seu espaço, como já se viu.

Após 1940, o quadro urbano, através de conquistas de no vas áreas, amplia o espaço, definindo-se no atual.

o processo de ocupação dos últimos 30 anos não foge dạ quele verificado desde o nascimento da cidade: preenchimento dos lotes e áreas vagas próximas àquelas já edificadas, surgindo na periferia, dos vazios. (Plantas 6 e 7)

Entretanto, as novas áreas não resultam de um processo u niforme e contínuo, tanto nas suas orientações quanto no tempo. Com o passar dos anos verifica-se que um novo espaço ou espaços urbanos ou rurais da periferia são loteados e incorporados ao quadro citadino: Contudo embora surja o loteamento a ocupação deste não se faz imediatamente e em alguns casos permanecem por longo tempo a espera desta, o que pode estar ocorrendo ainda ho je e cujo exemplo mais significativo é a Vila Nova.

A década de 1940 abre a cidade em direção sul com prolon gamento entre as ruas Iopè, Siqucisa campos, do Cinüsio a a EI trada de Ferro. Na mesma direção, como um loteamento isolado, nasce a Vila Nova. Em direção leste (Barra Funda), o espaço con quistado estende-se da Cia. SAAD, além da Estrada de Ferro, à rua Lutécia no extremo oposto, sendo o limite leste representa do pela rua Alegre. Para o oeste o avanço resume-se na passagem dos limites da cidade, fracamente ocupados, da rua Marechal Deo doro para a Conselheiro Rodrigues Alves e algumas quadras inter caladas além desta.

Nestes dez anos das novas áreas conquistadas, aquela em direção sul é a que se apresenta mais edificada.

A partir de 1950 o crescimento espacial da cidade é subs. tancialmente menor que o da década precedente, caracterizando-se muito mais pela ocupação intensiva das áreas já integrantes da cidade.

Os novos espaços, na sua quase totalidade definidos an tes de 1960, resultam de avanços para o sul, através da vila Ată de, para sudoeste com o Jardim Paulista e oeste com a Vila Gal dino, coincidindo praticamente com limites definidos pe]a Lei Municipal no 856 de 06 de maio de 1969, embora esta envolva ter 
ras, no lado sul, que ainda estão ocupadas por pequenas chạ caras. $(54)$.

Os setores de atividades não apresentam grandes altera ções à ocupação do solo urbano, exceto, alguns serviços e a edi ficação residencial.

As atividades industriais, comerciais e de serviços, nes tes 30 anos apresentam uma evoluçã் na qual estabelecimentos sur gem, transformam-se, permanecem ou mesmo desaparecem no conjun to urbano.

o setor secundārio, com atividade principal ainda volta da para a transformação de produtos agrícolas, e dinamizado , principalmente nos fins da década de 40 e início da de 1950.

Verifica-se a implantação de beneficiamentos de café e arroz, beneficiamento de algodão, fábrica de óleos vegetais (55) serrarias, torrefações de café, cortumes, fecularia, fäbrica de bebidas, marmorarias, indústrias químicas (sabão, cera, perfuma ria) etc..

As indústrias algodoeiras permanecem nas extremidades da cidade, junto à ferrovia, enquanto que as demais encontram-se / disseminadas não longe do centro da cidade, exceto o curtume a a fecularia (mandiona): gue estãn prñximnc an piheirãn মllegre. face às necessidades de água.

Entretanto, ao findar a década de 1960, muitas destas im

(54) Lei 856 de 06 de maio de 1969. ..."Começa na cerca divisó ria da E.F.Sorocabana, margem esquerda, na rua Fermino Gar cia e por esta em toda a sua extensão, e daí contornando o limites do Campo de Aviação, face leste, até encontrar a rua Tiradentes; por esta até 100 metros além da rua Coro nel Sanches Figueiredo, paralela a esta, em linha reta até - prolongamento da rua Bandeirantes e, por esta até 100 me tros antes da Av. Galdino e daí numa linha paralela a esta até encontrar a rua Alegria; por esta até a rua Amazonas até a rua Alabastro; por esta até a avenida Siqueira Cam pos; daí em linha reta até o canto sul do Estádio Munici = pal, na rua 7 de Setembro; segue em linha reta, acompanhan. do o muro do Estádio lfunicipal, lado sul, e daí atravessan do os trilhos da E.F.Sorocabana, diretamente até encontrā a rua Fernando Costa; daí segue por esta até a rua osvaldo Cruz, descendo por esta até a rua Alegre e por esta, até $265,60 \mathrm{~m}$. além da rua Lutécia, subindo em linha reta, para lela à rua Lutécia, até a Av. Gago Coutinho e daí, em 1 í nha reta, até a rua Fermino Garcia, onde teve seu início.

(55) Beneficiamento de algodão da SAAD e SANBRA (1945 e 1942); fábrica de óleos vegetais da Anderson Clayton (1947 ou 1949). 
plantaçōes industrlais haviam encerrado suas atividades. (Como se viu no Cap. 3.1.)

A atividade comercial, que apresenta um crescimento bas tante lento após 1950, permanece com os mesmos tipos de estabe lecimentos, havendo melhor caracterização destes, isto é, desa parece aos poucos a presença das casas de comércio variado ce dendo lugar à uma especialização (tecidos, calçados, secos e mo Ihados, etc.) Neste setor de atividades se verifica, também, o surgimento de estabelecimentos que após algum tempo encerram as suas atividades.

As novas implantações comerciais permanecem na sua gran de maioria no centro da cidade, verificando-se apenas um prolon gamento intermitente desta ao longo da rua 7 de setembro ou na forma de comércio de ponta de rua, que com o passar do tempo são envolvidas pelas residências.

o terciārio de serviços, após a função residencial, é o que apresenta maior crescimento e diversificação de atividades.

são caracterizados, de um lado, pela presença da adminis tração pública que insere na cidade as escolas, os serviços pú blicos municipais, estaduais e federais e de outro, pelás exi gências advindas das necessidades urbanas (outras escolas, hos tal, escritórios, bancos, etc..). Estes últimos são quase que essencialmente de iniciativa particular.

Estas novas atividades, exceto escolas, hospital, posto de sementes, serviço de água, campos de práticas esportivas, per manecem no centro ou periferia deste.

As residências expressam de forma predominante os limites da ocupação do espaço urbanizado. A cada década este ou aquele avanço para novas āreas se consuma pela presença de habitações, e são maiores ou menores face às exigências de domicílio por par te da população.

A década de 1950 é a mais expressiva quanto ao crescimen to residencial.

As mudanças econômicas ocorridas no município, entre mea dos da década de 1940 e 1970 refletem diretamente na população rural e urbana.

Durante a década de 1940 ainda é marcante a presença do algodão e do café. Entretanto a partir da segunda metade desta estas culturas entram em declínio, surgindo ao lado a pecuária como atividade mais importante, passando a ocupar não somente āreas de lavoura, mas também, aquelas recém-desmatadas e cerra dos. 
A maior expansão da pecuāria ocorre na década de 1950 , so frendo arrefecimento na seguinte, embora com uma expressiva ocu pação das áreas pelas pastagens. (Quadro 9)

A população do município traz, censo após censo, uma es tabilidade numérica, o que demonstra uma perda constante do efe tivo populacional nestes 30 anos. (Tabela 17)

A zona rural perde parcela significativa de seu efetivo populacional, enquanto que a zona urbana, menos afetada neste aspecto e absorvendo grande parte deste contingente rural, apre senta um aumento numérico. Em ambos os casos, a década de 1950 é a mais expressiva, marcando, evidentemente, a maior expansão do núcleo urbano.

Ao final destas considerações sobre a evolução do espaço urbano, cabe lembrar o papel de alguns aspectos que influíram na orientação desta.

Desde o início os loteamentos constituem os elementos de maior importância na orientação da expansão urbana.

o primeiro, efetuado logo após a chegada da ferrọia, de fine a malor expansão da cidade para oeste. Entretanto, sua lo calização nāo é fruto de uma açao isolada, mas resultante, ao que nos parece, da interação de pelo menos dois outros fatores: a colocação da pequena estação a oeste dos trilhos e a presença de Conceição de Monte Alegre, núcleo que comandava as relações da região, localizada tambēm neste lado da Estrada de Ferro, em bora a alguns quilômetros da estação e com posição mais sudoes te. Estes fatos conduzem o proprietário das terras à realização deste loteamento nesta face da ferrovia.

A partir deste momento o fazendeiro prossegue nas vendas de lotes e chácaras, sem interesse especulativo ou objetivo de dar esta ou aquela orientação ao crescimento do núcleo.

Entretanto, os novos proprietários das terras urbanas , procuram, face a um espírito de lucro, atrair a cidade para as āreas adquiridas.

A primeira área, dentro destes objetivos, adquirida em 1930, por J.R., professor em Conceição de Monte Alegre e S.H. , deu origem à Vila progresso (56). No que tudo indica e pela plan

(56) De acordo com Certidão do Cartório de Registro de Imóveis, a parte de terras adquiridas, por ambos, se achava dividida em 12 quarteirões, entre a avenida Monte Alegre, terras de Antonio Monteiro da Silva, ruas Minas Gerais e rua 24 de Fevereiro, somando mais ou menos 12 quadras. 
ta de 1938, estes efetuaram a venda dos lotes logo após a aqui sição das terras.

A leste da ferrovia (Barra Funda), os terrenos vendidos pelo proprietário da fazenda, resumiam-se a uma faixa cujos li mites iam pouco além das atuais avenidas José Jorge Esteves e Gago Coutinho, entre as atuais ruas João Batista Vieira e Oscar Bressane. Estas terras não constituíram loteamentos e atraíram apenas parcela do comércio (rua José Salomão, parte das avení das José Jorge Esteves e Gago Coutinhol e a serraria, cujo pro prietário utiliza na época, apenas parte das mesmas para a cons trução de casas aos operários (toda a face leste da atual aveni da Josè Jorge Esteves.).

Além dos limites acima referidos, havia a presença das pastagens na Fazenda 3 Barras.

Uma segunda fase de loteamentos ocorre entre 1940 e 1960. o Engenheiro L. adquire uma gleba superior a 10 alqueires da Fa zenda 3 Barras e que posteriormente foram loteados, com a deno minação de Vila Affini. Nesta mesma época, o fazendeiro formali za um grande loteamento que abrange as terras até então pasta gens, alēm da av. José Jorge Esteves e Gago Coutinho, cäracteri. zando em definitivo a Barra Funda. Un terceiro loteamento surge a sudoeste: a Vila Nova, com uma posição bastante isolada, como um apêndice ao núcleo urbano.

Nos três casos apenas o loteamento sul exerce atração su ficiente, orlentando a rápida expansão do espaço urbano nesta direção. O loteamento da Barra Funda arrasta lentamente a cida de naquela direção, enquanto que a Vila Nova permanece isolada, com uma atração quase que nula.

Em meados da década de 1930, F.J.S.V., adquire chācaras que somam pouco mais de 15 alqueires, localizadas no extremo oeste da cidade.

Este proprietārio procura atrair a cidade em direção às suas terras, efetuando doações, as primeiras no início da déca da de 40, a colégios, serviços públicos, clubes, ao mesmo tempo que deixava espaços vazios e que posteriormente foram loteados, culminando no esboço da Vila Galdino que, nestes ültimos anos, começa a ser ocupada.

Completando esta fase surgem dois loteamentos: Vila Atay de (1954) e Jardim Paulista (1954).

A Vila Atayde constitui: um prolongamento da Vila Affini, verificando-se contudo, que esta não exerce a mesma atração, a 
presentando ainda hoje claros bastante nítidos na ocupação.

o Jardim Paulista, que surge entre o Cemitério, rua Enge nheiro Loschi e terrenos da Fundação Gammon, com aproximadamen te 500 lotes ( 7 alqueires), tem objetivo formalizado de especu lação imobiliária. Em que pese toda sua organização, este lotea mento demora perto de 20 anos para ser ocupado.

Completando o quadro há a presença de um loteamento bem recente; o Jardim Panambi (1974), que ocupa terras que durante quase 50 anos perteceram à serraria Almeida Porto, localizado no extremo norte da cidade. Este loteamento constitui uma pers pectiva de orientação na expansão do espaço edificado da cidade.

Um outro fator orientador desta expansão urbana foram as saídas para as estradas. Entretanto, o papel destas é relativa mente restrito, aparecendo, com maior ou menor destaque, na me dida em que conduzem a um centro urbano mais importante ou en tão são valorizadas no processo evolutivo da cidade.

iNo primeiro caso há a antiga saída para Assis, que torna o prolongamento da rua 7 de Setembro, tendo-se constituido em uma das mais importantes do ponto de vista econômico urbano.

No segundo caso temos a antiga saída para Lutécia, que na facc inicial exercia o päpel de liyaçãu entre a ciaane e as āreas rurais a leste e sudoeste. E a única rua da cidade cuja origem corresponde a um caminho rural, do qual ainda guarda par te do traçado.

Uma terceira saída, que soma os dois aspectos, é aquela que atualmente conduz ao acesso à Rodovia Raposo Tavares e à Rodovia asfaltada SP-284. Atualmente constitui-se na única saí da asfaltada a estas rodovias. Nos primórdios foi o carninho de ligação entre Concelção de Monte Alegre e a Estação Ferroviária e ao núcleo urbano que nascia. (Vide Equipamento püblico Urbano).

Nos três casos houve uma disposição linear dos imóveis ao longo das mesmas, que à medida em que a cidade avançou, absor vendo-os, novo prolongamento surgiu, estendendo-se novamente na rua. Estes fatos tem maior destaque com relação à antiga saída para a estrada que conduz a Assiz.

Finalmente, um aspecto constitui obstáculo à expansão ur bana: as terras adquiridas pela Serraria Almeida Porto, locali zadas ao norte da cidade. Estas permanecem por longo tempo cer cando o avanço urbano nesta direção. Só recentemente este blo queio foi rompido com a presença de estabelecimentos públicos (CEAGESP, e Ginásio Estadual) e com as vendas das terras, possi bilitando a execução do loteamento do Jardim Panambi. 


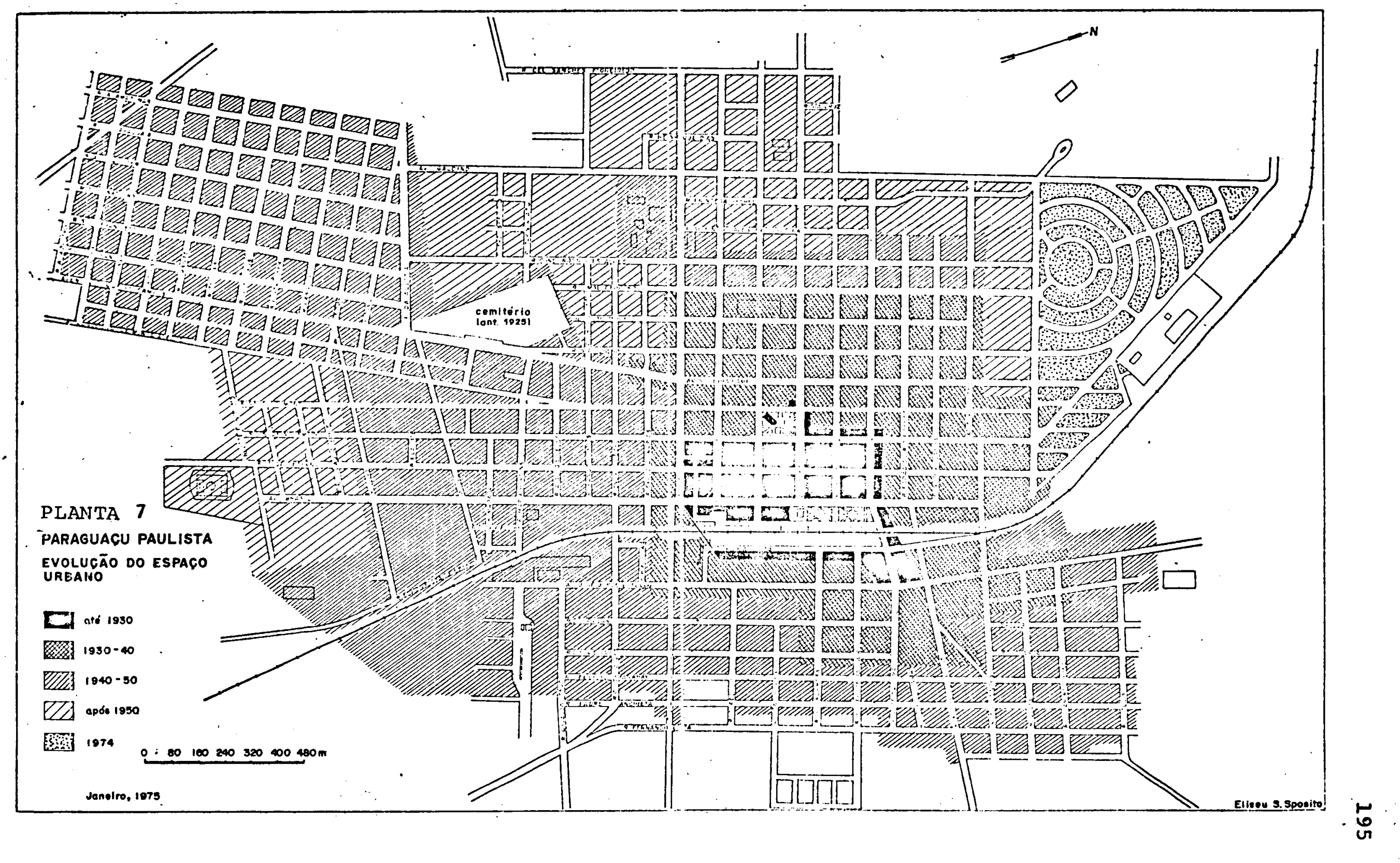




\subsection{Estrutura Urbana}

A paisagem urbana da pequena cidade de Paraguaçu Paulís ta, não apresenta a complexidade nas relações entre a estrutura funcional e socio-econōmica e a morfologia, sendo, portanto, di ficil definir unidades que possam ser consideradas bairros.

Do ponto de vista funcional, não hã delimitação rígida nas formas de ocupação do solo urbano. o que se verifica è a existência de um centro onde dominam os imóveis voltados princi palmente para o comércio, embora esta atividade extravase além deste na forma de prolongamentos, principalmente na direção sul ou pontilhando a cidade, com pequena importância econômica e com aspecto complementar: empórios bazares, bares, etc.. (Plan ta 8)

A faixa contígua a este centro é caracterizada pela pre sença do terciärio de serviços, mais marcante nas direções oes te-noroeste. Além desta faixa, os serviços estão dispersos, mas de certa forma equidistantes e organizados, voltados principalmente para os serviços públicos, escolas, hospital, praças de esportes, clubes. Esta dispersão resulta da necessidade de maio res espaços e conveniência de localização, definidos pela admi nistração pïhlica: nara oste nu aquele serviço. NNa sủa maioria são frutos de desapropriações ou doações, estas ūltimas muitas das vezes expressando o interesse de valorização fundiāria por parte do doador.

A atividade industrial, com predominio da transformação de produtos agrícolas, quando presentes na área central ou fai xa contígua a esta, é pouco perceptivel, face à sua dispersão é por se constituirem, em grande parte, de imóveis adaptados 'à função e com estabelecimentos industriais relativamente peque nos, cujas atividades e tipos de jmóveis utilizados se confundem muitas vezes, com a atividade comercial.

As'índústrias de maior expressão (beneficiamento e extra ção de óleos vegetais), encontram-se afastadas do centro, locá lizadas às margens da ferrovia. A necessidade de espaço, meio de transporte próximo e o baixo valor dos terrenos, foram os elementos essenciais de sua localização.

Completando o quadro destas formas de ocupação do solo urbano, hã os imōveis residenciais, que dominam por toda a cida de, tendo inclusive, certa expressão junto ao centro da mesma.

Neste conjunto apenas a Barra Funda apresenta certa unt dade que poderia dar-lhe caracteristicas de bairro. Nesta há 
uma pequena função comercial, nascida com a cidade; presença de alguns elementos do terciário de serviços; algumas indústrias e imóveis residenciais com aspecto bem definido.

Embora encerre estes elementos, cujo relacionamento the dá uma estrutura, a Barra Funda, pela contigüidade e continuida de que tem em relação ao centro, é a parte integrante e depen dente do restante da cidade, só não sendo totalmente, pelo sec cionamento do espaço urbano através da éstrada de ferro.

A definição de uma estrutura sōcio-econômica na paisagem urbana, torna-se mais difícil ainda. Não se encontra na cidade uma compartimentação rígida das classes sócio-econômicas. o que se verifica é a presença de população de todos os níveis em to da a cidade, havendo, entretanto, predominância de população po bre ao lado daquela que pode ser considerada de classe média.

Através dos critéríos de área construída, tanto residencial quanto das demais funções, densidade populacional, telefo nes residenciais, lançados sobre a divisão setorial utilizada pe lo IBGE., no Censo de 1970, pode-se esboçar, na paisagem urbana a estrutura sócio-economica. (Plantas 5 e 8 )

Os setores de 5 a 10 , que constituem a periferia da cida de, apresentam, em linhas gerais, população de todos os' nĩveis econômicos, havendo, entretanto, predomínio de população com me nores recursos. Este fato pode ser caracterizado pela pequena / densidade da ārea residencial construída (na maioria pequenas residencias, com predomínio de construções em madeira, havendo inclusive construções em taipa), pelas maiores densidades popu lacionais e a ausência quase que total dos telefones que uma vez existentes, são na maioria comerciais (geralmente com dupla fun ção: residencial e comercial), de serviços ou industriais.

As áreas construídas para fins comerciais e serviços en contram-se presentes na periferia interna destes setores, quase que exclusivamente nos de n8 5 e 7 . A área industrial marca os setores 8 e 9 .

Os setores $1,2,3$ e 4 , igualmente abrigam população de todos os niveis, havendo, entretanto, um predominio de popula ção com maior poder aquisitivo ou de classe média. Nestes en contram-se elevada densidade de ārea construída para fins resi denciais (casa mais ampla; na maioria de alvenaria e de boa construção), comerciais e serviços. As densidades populacionais são as mais baixas e os telefones, tanto residenciais quanto pa ra outros fins, tem a sua marcante presença. (Plantas 5 e 8 ) 
Planta 8

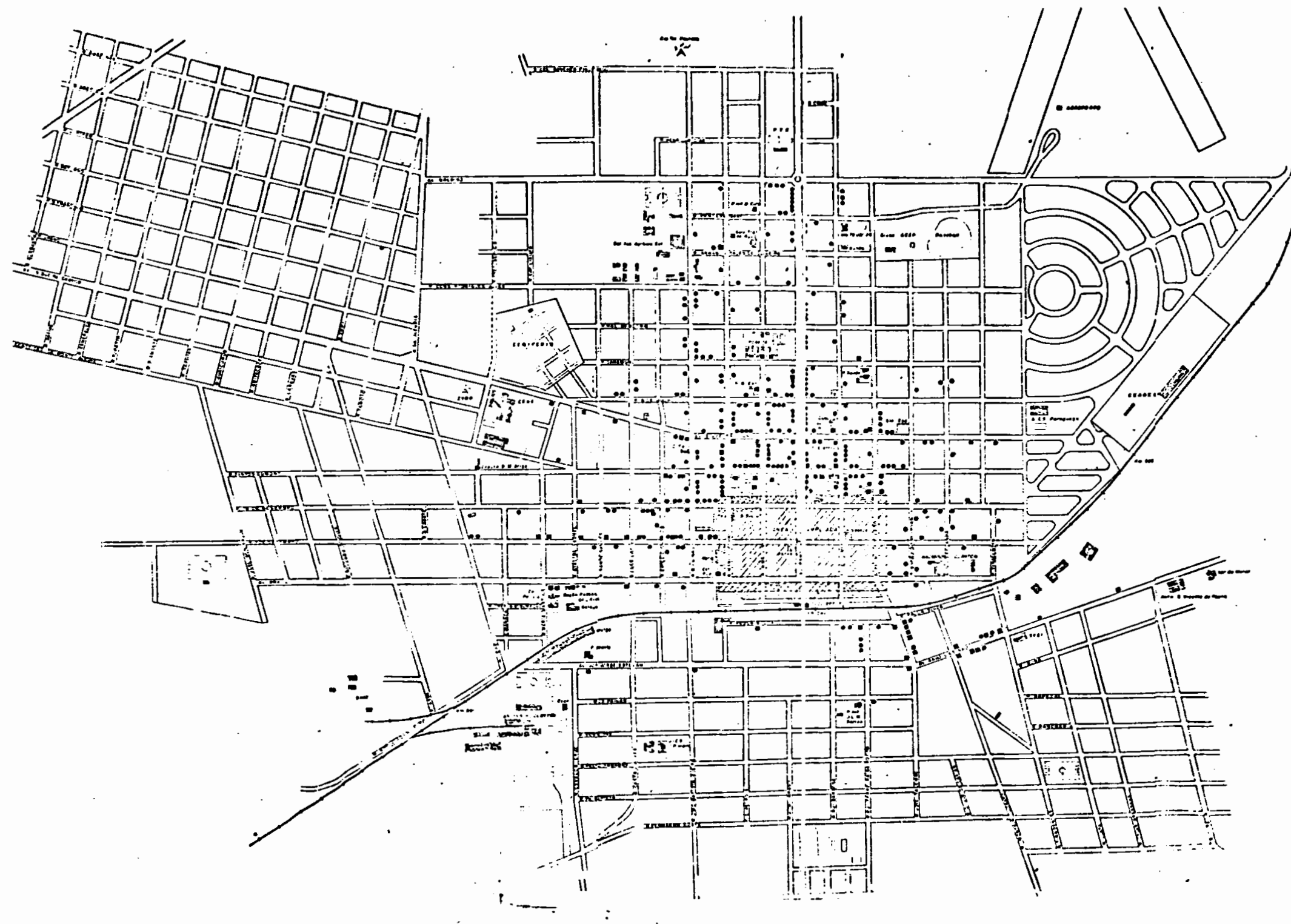

PARAGUACU PAULISTA

TELEFONES

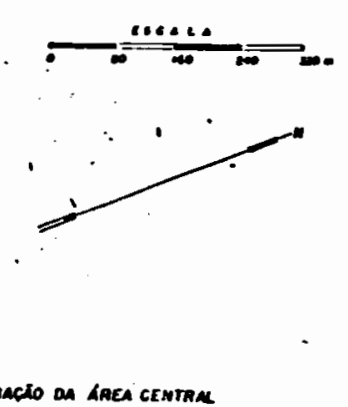

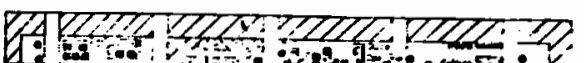

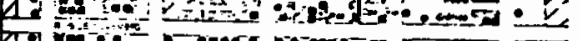
V1 : : : : ........ no.........

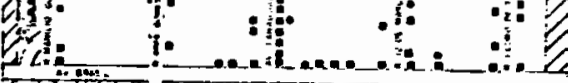

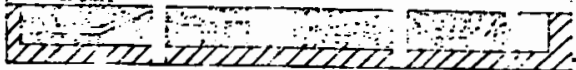
$:=$ 
Ainda nestes conjuntos, deve ser lembrado que nos limi tes extremos da cidade, onde há precariedade dos serviços públi cos e terrenos de baixo valor, define-se a presença da popula ção paupérrima.

Como exceção, nestes extremos periféricos, o oeste, mais propriamente o setor 11, esboça a presença de uma população me lhor aquinhoada economicamente, fato que pode ser observado pe lo recente surto de construções e qualidade destas, bem como daquelas construídas ha algum tempo.

Embora o setor apresente construções que demonstram esta melhor situação econômica de seus ocupantes, tanto neste quanto na paisagem urbana, no seu conjunto, verifica-se a ausência de residencias ricas, o que nos leva a inferir que há a ine xistência desta classe na população urbana ou pelo menos o seu mascaramento. Como reforço à inferencia, no consenso popular da pequena cidade, os considerados "ricos" constituem a prósperoco merciante, o fazendeiro ou o pequeno industrial local, que podem estar ocupando uma boa residência ou aquela que não reflete em nada a condição de seu ocupante.

Quanto à morfologia dos imóveis, tendo-se em conta a tê nue compartimentação socio-econômica e funcional, exceto os li mites extremos já referidos, verifica-se que há uma uniformida de aEstes puir iửa a liüade, onde os várıos aspectos das edificações, refletindo as diferentes posições sócio-econômicas. de seus ocupantes e as diferentes épocas de construção, se interca lam, de certa forma, intermitente e desordenada.

Face a estes aspectos, pode-se distinguir em Paraguaçu Paulista, com uma disposição mais ou menos concêntrica, diver sas faixas, cuja unidade è quebrada pela presença da estrada de ferro. Esta definição concêntrica será feita com o objetivo de visão de conjunto da cidade e distante de atribuir-lhe a teoria do "zonning".

Assim, a oeste da ferrovia, tendo como ponto de referência a ārea central, abrem-se numa forma que se aproxima de um le que, as seguintes faixas:

- Area Central, com características dominantemente comer ciais, mas com presença de serviços e residências;

- Faixa ou periferia contígua ao centro, onde os serví ços tèm papel representativo ao lado da função residen cial;

- Faixa ou periferia mais distante do centro, onde há o domínio da função residencial, abrigando ao lado a pre sença de serviços de certa forma dispersos e distribuí dos de forma equilibrada:

- Periferia da cidade, cuja característica fundamental é 
a função residencial de população pobre e em grande par te de origem rural.

A leste da Estrada de Ferro é possivel definir apenas a Barra Funda como um todo.

No conjunto espacial, a área central e a Barra Funda são passiveis de individualização, face às suas características.

A área central corresponde ao quadro delineado pelas ruas Manílio Gobbi, Santos Dumont, Pedro de Toledo e Avenida Brasil. Neste conjunto apenas as ruas Manílio Gobbi e 12 de Março tem menor importancia em relação às demais. (Planta Funcional)

Esta área, cuja definição data do nascimento da cidade , traz uma concentração de imóveis voltados para o comércio e em segundo plano para os serviços e residèncias. O fenômeno resí dencial é quase sempre associado às atividades aí existentes, a parecendo, também dissociados e mais dispersos. No caso da asso ciação a sua presença se faz nos fundos dos imóveis ou então 으 cupando a parte superior daqueles de dois pavimentos, somando estes últimos aproximadamente uma quinzena.

As edificações voltadas para o comércio e serviços aprę sentam morfologia homogênea: construídas em tijolos, portas de ferrn, contiguas, frente junto an limite do terreno e na sua maioria com mais de 30 anos. As diferenças morfológicas destes, fazem-se sentir pela presença de reformas; dos poucos imóveis de construção recente, (menos de 10 anos)! ou daqueles construí dos para fins específicos: bancos, hotēis e pensões, cinema,clü be.

Deve ser lembrado ainda, que boa parcela dos imóveis que foram construídos para fins comerciais ou de serviços, estão atualmente ocupados por outras atividades e havendo alguns que já abrigaram mais de uma delas. Estes fatos, em alguns casos, estão ligados a imóveis residenciais.

Quanto às atividades predominantes destacam-se: bares, se cos e molhados, farmācias, vestuário e calçados no setor comen cial; hotéis e pensões, serviços de higiene pessoal,escritórios, oficinas de consertos e advogados, pelos serviços.

o setor secundário tem a sua presença através da padaria, marcenaria, tipografias e fābricas de móveis, Estas últimas 은 cupam imóveis outrora destinados a um clube (tipografia) e casa de comércio.

Pode-se distinguir apenas un prolongamento do centro que se faz ao longo da rua 7 de Setembro, em direção sul. Este pro 
longamento caracteriza-se pela atividade comercial e três peque nas indústrias. A sua presença resulta da valorização desta rua como uma das saídas importantes da cidade, hoje desviada para a avenida Siqueira Campos, e o crescimento da cidade na mesma direção.

A Barra Funda não possui estrutura suficiente capaz de defini-la como bairro, mas possui características e elementos que nos parecem suficientes para individualizá-la.

Este espaço urbano, iqualmente definido com as origens da cidade, apresenta uma pequena concentraçäo de imóveis volta dos para a atividade comercial, alguns serviços, principalmente educacionais, poucas industrias, mas com a presença da mais im portante da cidade, e, evidentemente, residencias.

o seu pequeno centro comercial apresenta morfologia que guarda as meșmas características da área central, possuindo, en tretanto, alguns deles idades mais avançadas (mais de 40 anos). Igualmente, muitos destes têm nos fundos a presença da residên cia do proprietário.

As atividades são mais limitadas: secos e molhados, empó rios, posto de gasolina, bazares e bares constituem mais de $85 \%$ destias.

Os serviços são representados pela atividade educacional, parque de diversão infantil, cursos primărios e ginásio, posto de sementes, igrejas e hotel, que se encontram dispersos.

Os seus imóveis que tem morfologia definida pelo fim es pecífico a que.se destinam, são de construção relativamente re centes, com exceção do hotel.

o setor industrial è representado na Barra Funda pela fá brica de óleos vegetais, panificadora, beneficiamento de arroz, funilaria, serraria, esta ültima com suas atividades encerradas.

o setor residencial, com exceção da área próxima ao sẹ tor comercial, é predominantemente de madeira, cuja morfologia é bastante uniforme, onde as diferenças definem-se mais pela idade dos imóveis.

Finalmente, as relações espaciais e funcionais destes dí ferentes elementos è que definem na paisagem urbana a sua estrú tura.

As maiores relações fazem-se entre as älferentes partes da cidadc com a ärea central e faixa contígua à está, para onà converge a população para atendimento de suas necessidades de consumo, serviços, recreação e trabalho. Entretanto, para os 
serviços mais ligados à educação, saūde e recreação, definem-se maiores relações de toda cidade com a periferia mais distante do centro. A fragilidade da função comercial desta faixa da pai sagem urbana, limita o seu relacionamento com o restante da cí dade, mas cria relações com a área que the é próxima.

Um outro tipo de relaçōes se verifica entre a periferia da cidade e mesmo das faixas periféricas ao centro com a zona rural. Este relacionamento é principalmente de trabalho: das bordas da cidade são recrutados os volantes ou bóias-frias para os trabalhos diārios da agricultura, enquanto que as faixas pe riféricas ao centro constituem āreas de maior frequência de re sidências de proprietários rurais.

Deve-se lembrar que nos períodos de entre safra e mesmo durante esta, as relações de trabalho desta população pobre da periferia urbana, fazem-se também com a cidade, principalmente, para os trabalhos mais rudes.

Estes mesmos aspectos surgem na Barra Funda. Hā conver gência de relações de todo este espaço para o pequeno centro co mercial aí existente, ao nível de abastecimento e, em escalabem menor, de trabalho.

Quanto aos serviços, estas relaçöes säo mais difusas, ten do em vista a localização dispersa das escolas, igrejas, posto de sementes e campos de esportes.

A presença da fábrica de óleos vegetais traz para este ponto um valor razoável nas relações de trabalho.

A exemplo da parte oeste da cidade, a Barra Funda mantém relações de trabalho com a zona rural e com a cidade, por con ter uma população pobre sem nenhuma definição profissional e pouquíssimos proprietārios rurais.

Portanto, embora cada faixa ou setor possua um conteúdo funcional, sócio-economico e morfológico a cidade é constituída por um conjunto orgânico de suas partes, supondo relações de dependência entre as diversas partes; sendo, ao mesmo tempo, es paciais e funcionais.

A organicidade destas relações completa-se pela circula ção que, face às dimensões da cidade, não hã necessidade de trans portes coletivos, sendo comum a circulação a pé ou através de veículos particulares, cujo número é razoável na cidade. 


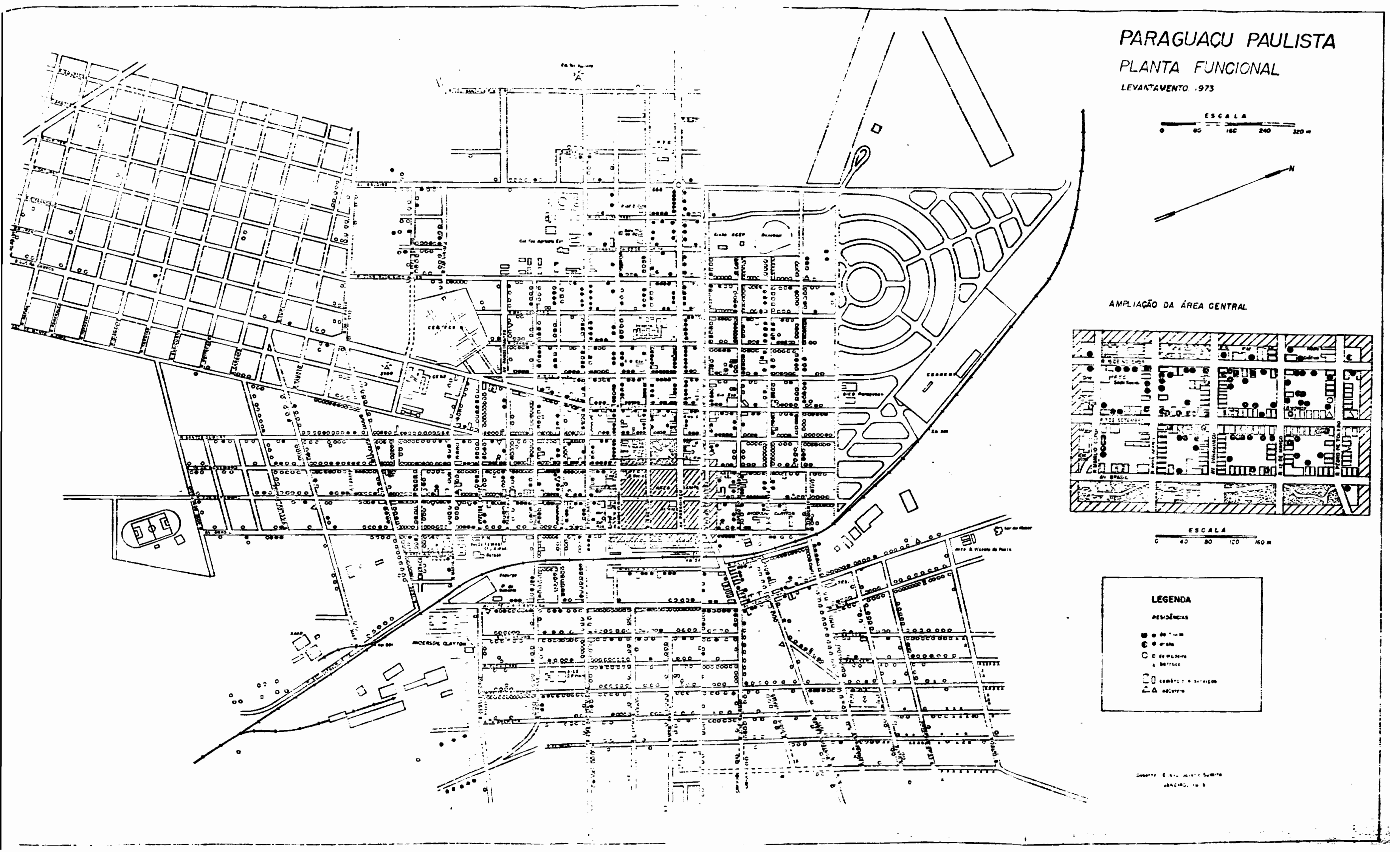




\section{CONCLUSÕES}

- fenômeno da intensa urbanização paulista, refletido pela grande concentração paulistana e capitais regionais, gera um pro cesso que define para estas não apenas a atração populacional, mas o domínio das atividades humanas, resultando no esvaziamento das pequenas cidades e zonas rurais das regiões sob suas influ ências. Como centro econômico, político e social, a cidade de São Paulo, metrópole nacional, constitui o ültimo nível de con centração urbana do Estado e do País, exercendo um domínio qua se absoluto sobre todo o espaço bandeirante. As capitais regio nais constituem, do ponto de vista geográfico, o nível mais ime diato deste processo de dominação, concentrando diferentes ati vidades e comportando-se como "relais"entre a capital paulista, e as regiões interioranas. Esvaziam o setor secundārio das pe quenas cidades na medida em que passam a concentrar as ativida des industriais principalmente ligadas às primeiras transforma ções dos produtos rurais, sendo mais marcantes os beneficiamen tos e as indústrias de distribuição. Com relação ao terciário as capitais regionais tornam-se os centros do comércio atacadis ta, o setor varejista diversifica-se, enquanto que os serviços adquirem melhor padrão e níveis mais raros. Entretanto, embora exerçam dominação sobre regiões considerāveis,descapitalizando os campos e concorrendo com as pequenas cidades, diminuin do-ihes a autonomia, as grandes cidades paulistas vão se tornan do dependentes da grande metrópole paulistana que conserva o po der de decisão e comando, definindo para o espaço interiorano a condição de periferia, onde as capitais regionais permanecem co mo intermediárias econômico-administrativas entre o centro e a periferia. iveste conjunto de relações, a permanência das pequenas cidades se faz pelas mudanças ocorridas na economia rural,. marcadas pela penetração das relações capitalistas, restringin do-as à condição de pequenos centros redistribuidores de gêne ros e serviços e residência de médios proprietārios rurais e de trabalhadores rurais, particularmente bóias-frias.

Na Alta Sorocabana, pequenas, médias e grandes cidades , comportam-se ao longo de suas evoluções como centro de coleta, beneficiamento e expedição de produtos rurais aos grandes cen tros consumidores distantes, cujas necessidades geram estímulos que explicam a evolução cíclica de suas produções. Ao mesmo tem 
po, constituem os instrumentos de distribuição de gêneros e ser viços necessārios ao espaço com o qual se relacionam. Como con seqüência deixa de existir o poder de decisão sobre suas econo mias, uma vez que estas são tomadas e definidas externamente e a vida de relações fica dependente das alterações que os inte resses externos definem na sua área de dominação.

Paraguaçu Paulista constitui na rede urbana da Alta Soroca bana um dos exemplos de centro local, cuja vida de relações se faz bäsicamente com a ārea imediatamente vizinha, particularmen te seu próprio município.

Nascida do avanço da frente pioneira em direção ao oeste do Estado de São Paulo, o centro urbano paraguaçuense em toda sua existência apresentou seu maior ou menor crescimento ditado pelo setor primário a começar pela atividade criatória herdada do precursor mineiro e sucedida pelo.café, algodão, pecuá ria e, maịs recentemente, pela presença do trigo e da soja.

No momento em que predominam o café e algodão, lavouras al tamente comercializāveis, o centro floresce, desenvolvendo sua função de coleta, beneficiamento e expedição destes e outros ' protutos primários ao lado da distribuição da gôncros a scruiç a uma população urbana e rural em processo de formação e crescí mento. .Nesta fase as relações entre a cidade e as āreas rurais contíguas e mais distantes foram bastante estreitas. Em seguida um outro quadro se apresenta (fins dos anos 40 e início da déca da de 50) com a expansão das pastagens em detrimento das lavoú ras, provocando o desequilíbrio econômico e populacional que se acelera nos anos 60 .

Tais fatos podem ser generalizados para o oeste paulista, tendo já sicao assinalado por Monbeig no momento em que questio na e conclui: "A substituição dos cafezais e das plantações de algodão pelas pastagens será seguida pela instalação de frigorí ficos e a indústria da carne poderá substituir as máquinas de beneficiamento?... Quer se oriente neste sentido ou se assista a uma mudança dos métodos agrícolas e da mentalidade paulista, - futuro das cidades permanecerá confundido com aquêlo dos cam pos". (57).

(57) Monbcig, Picrre, obra cit. pāg. 346. 
Realmente, a partir do instante em que as pastagens se aflrmam na Alta Sorocabana, surgem os frigoríficos, mas localiza dos quase que essencialmente nos centros maiores e no bordo oes te da região, mais próximo às áreas de invernadas para engorda . No bordo leste, onde se encontra Paraguaçu Paulista, as máquinas de beneficiamento permanecem. Embora as pastagens avancem, 0 se tor primārio apresenta-se basicamente o mesmo, verificando-se a penas a mudança de produtos face às exigências do mercado consu midor distante, gerando apenas a adaptação da função de coleta e beneficiamento à produção primāria, de acordo com a sua sucessão. Como exemplo destes fatos hã a presença e o comportamento das grandes empresas de âmbito internacional e nacional (Anderson \& Clayton, SANBRA, SAAD, Matarazzol que se instalam na região. A chegada destas ocorre com o desenvolvimento da lavoura algodoe ra. No início seus equipamentos se restringem às usinas de bene ficlamento do produto, acrescentando, alguns anos após, as fábri cas de óleos vegetais. A partir do momento em que a cotoniculturá oscila, deixando de ser gradativamente um bom negócio, pelo retraimento do interesse do mercado internacional em relação ao produto além de outros fatores, verifica-se o afastamento destas empresas neste setor de produção, permanecendo na atividade ape nas para atendimento das necessidades nacionais. Os seus interes ses e investimentos voltam-se para outros produtos: amendoim, ma mona, soja, aparecendo esta última como solução e principal maté ria prima no momento atual diante dos interesses despertados tan to em âmbito nacional quanto internacional.

No caso específico de Paraguaçu Paulista, estas empresas aí encerram suas atividades, permanecendo apenas a Anderson clay ton que procura adaptar seu equipamento industrial à soja e pelo fato de que a cidade ocupa uma posição espacial que the é inte resante: próxima às āreas de produção da matéria-prima (Alta so rocabana, Norte do Paraná, Sul de Mato Grossol e do grande mercá do consumidor e exportador (São Paulo) e em um eixo onde o equi pamento viário proporciona um único fluxo da coleta à elaboração final, consumo e exportação da produção industrial. Entretanto , esta solução coloca-se ao nível de atendimento dos objetivos das grandes emprêsas concentradas nos grandes centros urbanos. Não reflete as transformações ocorridas nas organizações e na vida de relações do neio rural e ảas pequenás ciảades.

$o$ que se verifica,e o pequeno centro local em questão refle te o fato, é o aprofundamento das relações capitalistas na zo 
na rural favorecendo globalmente as relações a partir da cidade, cujos graus de dominação se estabelecem segundo os níveis de ur banização que estas apresentam.

Nas ũltimas décadas há uma rápida diminuição do setor agrạ rio de autorsuficiência, principlamente produção de gêneros, pas sando o homem rural a adquiritlos na cidade, gerando maior depen dência em relação a esta. Ao mesmo. tempo, os hábitos de consumotornam-se mais sofisticados pela maior variedade de produtos ofe recidos, passando a população urbana e rural a consumir mais, tanto gêneros voltados às suas necessidades básicas e mesmo bens de consumo durāvel, quanto equipamento para a produção. Esta pe netração capitalista tambēm se faz sentir nas relações de trabalho no meio rural, fortalecendo a presençà urbana, uma vez que esta passa a exercer dominação sobre grande parcela da renda fun diāria, meios de produção e força de trabalho, isto porque tanto proprietários, quanto assalariados rurais passam a fazer ảa cida de a sua residência.

Estes fatos afetam a população. A partir de meados da déca da de 1940, os campos despovoam-se, enquanto que as cidades : aumentam o seu efetivo populacional. No caso particular de Paraguaçu Paulista, este crescimento verifica-sé pela absorção de parte do excedente rural ao limite das ofertas das possibilidades de trabalho da cidade, ao mesmo tempo em que hã a fixação de um contingente que permanece ligado às atividades rurais. .. 0 aumento da população urbana não se deveu a um processo típico de urbanização, no sentido de que esta ocorre pela ampliação do se cundário e terciário, tendo-se em conta que estes não cresceramao nivel de justificar o crescimento populacional. A partir dos anos 60, o esvaziamento rural não é compensado pelo crescimentoda população urbana, entrando esta em processo de perda, signifí cando que, de um lado, a zona rural aparentemente atingiu os li mites de absorção de mão-de-obra necessária aos seus trabalhos e por outro, houve a limitação dos setores secundārio e terciárioque absorvem de forma muito lenta ou quase nula, este excedenterural. Muitos dos que permanecem, principalmente de origem rural constituem o mēdio e grande proprietārio rural absenteísta ou aqueles que, sem o mínimo de condições profissionais ou educacio nats, fixam-se na periferia trabalhando como volante ou em sub empregos que a cidade eventualmente oferece e quase que essen- / cialmente atravēs do setor terciário, acarretando tanto a dimi-/ nuição do mercado consumidor quanto do fornecedor de matérias - 
primas, refletidos na estagnação da cidade nestes anos. O pro cesso nesta década de 60 desencadeia o esvaziamento rural e ur bano, principalmente da população jovem, no sentido das capitais regionais, da cidade de são Paulo e menos vigoroso para outras áreas, inclusive fora do Estado.

Entretanto, na década vigente, a presença de produtos rụ rais que gozam de vantagens tanto no mercado externo quanto in terno e que exigem modernização dos meios de produção, a exiś tência de uma burguesia e administração local, cujas iniciatí vas aproveitando-se das vantagens locais, procuram explorar as possibilidades dentro do processo de concentração urbana, cons tituem os fatos que refletem a sobrevivência da pequena cidade paraguaçuense no atual contexto urbano do extremo sudoeste pau lista.

o desenvolvimento das lavouras do trigo e da soja, permi tiu maior aprofundamento das relações capitalistas na medida em que; como produtos altamentes comercializávels, exigem uma mo dernização da produção, acentuando as relações dos campos e à reas próximas ao pequeno centro paraguaçuense, favorecendo prin cipałmente as relações comerciais. A existência de uma burgue sia local, surgida da acumulação de rendas proporcionadas prin cipalmente pela zona rural, acentua sua presença na medida .em que dominam fortemente a renda fundiária è detém parte da come $\underline{x}$ cialização da produção rural e da distribuição dos gêneros, se viços e produtos necessārios à produção. A sua presença, entrẹ tanto, não se restringe à ārea munlcipal. Percebe e utiliza-se das vantagens oferecidas pela posição de Paraguaçu Paulista nos limites das zonas de influência de duas capitais regionais (Ma rília e Presidente Prudente), passando a atuar com relativa li berdade em um espaço onde os centros menores e menos equipados (Oscar Bressane, Jutécia, Borá, Quatá, Maracaí, Cruzália) pas sam a constituir sua pequena área do mercado. Intretanto, sua presença não se limita a esta pequena área, isto porque esta mesma burguesia local amplia sua área de ação, competindo com relativa igualdade, em determinadas atividades, com centros maio res (Assis, Presidente Prudente) seja atravēs do estabelecimento de comércio atacadista, da presença nestes centros maiores de filiais (I.D., Concessionários Massey Fergusson), ou através da

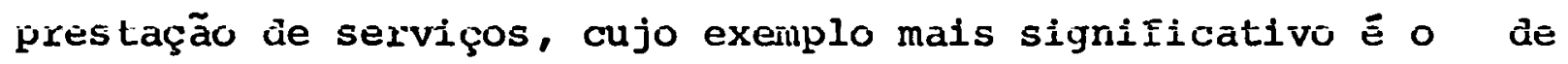
transporte de cargas. Somando-se aos interesses e iniciativas particulares, a administração püblica municipal através das suas 
iniciativas e relações políticas, procura atrair as atenções e Investimentos do poder público, principalmente da área estadual, na concretização e melhoria da infra-estrutura dos serviços (via rio, saneamento básico, educação, financeirol. Como complementa ção e fato importante, reforçando esta posição, a atuação conjūn ta desta administração e iniciativa particular local, dotam a cidade com estabelecimento de ensino superior (Agronomia), cujo curso não se sobrepôs aos existentes na região, que após insta lado extravasou os limites local e regional, reforçando a conco rrência com os centros urbanos de nível superior e a presença do centro urbano paraguaçuense.

Portanto, esses fatos que no momento atual marcam os pri mórdios de uma nova fase para Paraguaçu Paulista, constituem o esforço para sua sobrevivência no processo de concentração urba na regional e mesmo paulista. Entretanto, devem ser observados, com cautela, cońsiderando-se que a cidade não estā isolada, mas fazendo parte de um espaço onde as transformaçōes são reflexos da evolução política e econômica do momento, cujos estímulos são dirigidos ao fortalecimento das médias e grandes cidades, colo candọ em risco a sobrevivência dos pequenos. centros urbanos. 0 que se faz necessário para a permantencia dostas, pelo menos no seu estágio atual de desenvolvimento, não é a desconcentraçãoem

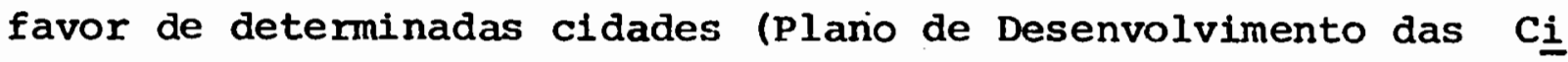
dades Médias), mas sim o estímulo as atividades existentes, pos sibilitando a ampliação do mercado consumidor regional e exer cer dentro deste uma concorrência com estas mesmas atividades da metrópole paulistana ou das capitais regionais, o que permi tirá o reativamento das funções destes pequenos centros e conse qüentemente, das relações entre cidades e entre estas e as zo nas rurais. 
210

B I B L I O G R A F I A 


\section{BIBLIOGRAFIA}

AB' SABER, Aziz N.

1969 - "A Terra Paulista" in Boletim Paulista de Geografia ne 23 - A.G.B., São Paulo.-

ABREU, Dióres Santos

1972 - "Formação Histórica de uma cidade pioneira paulista - Presidente Prudente". Faculdade de Filosofia, Ciên cias e Letras de Presidente Prudente.-

ALEGRE, Marcos

1972 - "População e povoamento" In Guia de Excursões, Is En contro Nacional de Geógrafos - A.G.B., Presidente Prي dente.-

ALEXANDER, Jonh $W$.

1968 - "Concelto bãsico-não bãsico dars funções econômicas ux banas" in Boletim Geográfico no 203 - Fundação IBGE, Rio de Janeiro.-

ARAUJO FILHO, José Ribeiro

1956 - "O café, riqueza paulista" in Boletim Paulista de Geo yLaíia n⿸丆 23 - A.G.B. , são Paulo.-

BEAJEU GARNIER, J.

1971. - "Geografia da População" - Companhia Editora Nacional, São Paulo.-

BEAUJEU GARNIER, J. e CHABOT, G.

1963 - "Traité de Geographie Urbaine" - Librairie Armand Co lin, Paris.-

BERNARDES, Lysia M. Cavalcant1

1960 - "Elementos para o estudo geogräfico de cidades" in Bo letim Geográfico no 154 - C.N.G., Rio de Janeiro.-

BERRY, Brian J.L.

1971 - "Geografia de los Centros de Mercado y Distribuición al por Menor" - Editorial Vicens-Vives, Barcelona.-

CAMARgo, José F. de

1952 - "Crescimento da população no Estado de são Paulo ' e seus aspectos econômicos" - Boletim no 153, Economia e Polftica e História das Doutrinas Econômicas - Uní versidade de São Paulo, São Paulo.-

CHABOT, Georges

1952 - "Les villes" - Armand Colin, Paris.- 
COBRA, Amador Nogueira

1923 - "Em um recanto do sertão paulista" - Tipografia Hen neyes, São Paulo.-

COPSTEIN, Gisela

1973 - "Tapes, cidade arrozeira na planície lagunar gaúcha" Dissertação de Mestrado - Faculdade de Filosofia, Le tras e Ciēncias Humanas da Universidade de São Paulo Instituto de Geografia, são Paulo.-

DERRUAU, MaX

1964 - "Tratado de Geografia Humana" - Editorial Vivens - Vị ves, Barcelona.-

1973 - "Geografia Humana" (2 volumes) - Editorial Presença, Lisboa. Livraria Martins Fontes, Brasil.-

DOLLFUS, Olivier

1972 - "o espaço geogrãfico" - Difusão Européia do Livro,Cọ leção Saber Atual n8 153, São Paulo.-

1973 - "A anālise geogräfica" - Difusão Européia do Livro, Co leção Saber Atual no 159, São Paulo.-

FRANÇA, ArY

1963 - "ì llarcila du café e as İrentes proneiras" in Guia no 3 do XVIII Congresso Internacional de Geografia - $c$. N.G., Rio de Janeiro.-

GEORGE, Pierre

1952 - "La ville, le fait urbanine travers du monde" - PUF, Paris.-

1963 - "Alguns problemas do estudo geográfico da população" in "Visita de Mestres Franceses" - IBGE, Rio de Ją neiro. -

1959 - "Questions de geographie de la population" - PUF, Tra vaux et Documents no 34, Paris.-

1969 - "Geografia Urbana" - Ediciones Ariel, Barcelona.-

1970 - "Les Méthodes de la Géographie" - PUF, Col. Que-Sais-Je? nil.398, Paris.-

GIOVANNETTI, Bruno

"Esboço Histōrico da Alta Sorocabana" - Empresa Grạa fica da Revista dós Tribunais, São Paulo.-

HUGON, Paul

1973 - "Demografia Brasilcirä ensuios de demoeconomia" Atlas, Editora da Universidade de São Paulo, Saõ Pau 10.- 
JUILLARDE, Etienne

1965 - "A região: tentativa de definição" in Boletim Geogrā fico no 185 - C.N.G., Rio de Janeiro.-

1961 - "Europa Industrial e Brasil: dois tipos de organização do espaço periurbano" in Boletim Baiano n̊ 4.-

KAISER, B .e outros

s.d. - "Un systeme d'informations sur les petites villes françaises" - Travaux et Documents du C.I.E.U. - Uni versité de Toulouse.-

KELLER, Elza C.S.

1954 - "Notas sôbre a evolução da população de são Paulo de 1920 a 1950" in. "Aspectos da Terra Bandeirante", C. N.G., Rio de Janeiro.-

1969 - "As funções regionais e a zona de influência de Cam pinas" in Revista Brasileira de Geografia, ano 31, ,n\& 2 - Fundação IBGE, Rio de Janeiro.-

LEITE, José Ferrari

1972 - "A Alta Sorocabana e o espaço polarizado de Presiden te Prudente" - Faculdade de Filosofiá, Ciências e Le tras de Presidente Prudente, Presidente Prudente.-

MAMIGONIAN, Armen

1960 - "Brusque: estudo de geografia urbana e econômica" Edição da Sociedade Amigos de Brusque, Brusque.-

1966 - "Estudo geogrāfico das indústrias de Blumenau" in Re vista Brasileira de Geografia, ano 27, n8 3 - Fundação IBGE, Rio de Janeiro.-

1973 - "Tendências recentes do processo de urbanização na Alta Sorocabana" - Comunicação - Anais da Associação dos Geógrafos Brasileiros, vol. XVIII, São Paulo.-

MARCON, Adistão

1974 - "A região polarizada por Sorocaba" - Tese de Doutora mento apresentada à Faculdade de Filosofia, Ciênias

e Letras de Franca, Franca.-

MERTON, Robert $\mathrm{K}$.

1965 - "Eléments de Theorie et de Méthode Sociologique" Librairie Plon, Paris.-

MILLIET, Sè̀rgio

1946 - "Roteiro do cafë e outros ensaios" - Bipa-Editora são Paulo.- 
MONBEIG, Pierre

1943 - "Estudo Geográfico das cidades" in Boletim Geográfico n8 7 - IBGE, Rio de Janeiro.-

1952 - "Pionniers et Planteurs de São Paulo" - Lib. Armand colin, Paris.-

MULLER, Nice Lecocq

1969 - "O fato urbano na bacia do rio Paríba" - São Paulo, C.N.G., Rio de Janeiro.-

1970 - "Jequié - Estudo de Geografia Urbana" - A.G.B. Avulso ne 7 (Relatório apresentado por ocasião da XVIII Assembléia Geral, ,realizada em Jequiē)- São Paulo.-

PEREIRA DE ARAUJO, ElY Goulart

1953 - "A Cidade de Olímpia (Estudo de Geografia Urbana" in Anais da A.G.B., volume V, Tomo I 1950-1951., São Paulo.-

PETRONE, Paquale

1956 - "O Homem paulista" in Boletim Paulista de Geografia no 23 - A.G.B., São Paulo.-

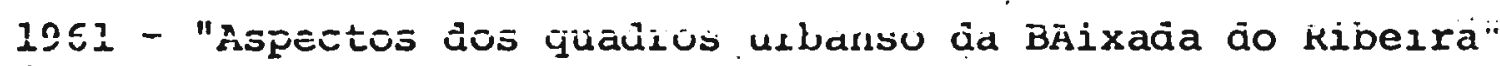
in Boletim Paulista de Geografia n\& 38 - A.G.B., São Paulo.-

1961 - "Notas sôbre o fenômeno urbano. no Brasil" in Anais da A.G.B., Vol XII, São Paulo.-

PERIDES, Pedro Paulo

1971 - "Dois Córregos: um exemplo de Centro Local" - Tese de Mestrado apresentada a.c Departarmento de Geografia da Faculdade de Filosofia, Letras e Ciências Humanạs da Universidade de São Paulo, são Paulo.-

PRESSAT, Roland

1967 - "El análisis demogrāfico" - Fondo de Cultura Econômi ca, México.-

ROCHEFORT, Michel

1964 - "Métodos de estudos das rédes urbanas" in Boletim Ge ográfico n̊ 160, IBGE, Rio de Janeiro.-

1967 - "Método de pesquisas das funções características de uma metrópole rcgional" in Boletim Geográfico no 198 IRGE, Rio de Janeiro.-

1974 - " O papel das cidades na regionalização. A política das metrópoles de equilíbrio". Palestra proferida no 
I8 Encontro de Planejamento e Desenvolvimento Regio nal. Secretaria de Economia e Planejamento do Estado de São Paulo. Mimeografado, traduzido por Marcio An tonio Teixeira, Faculdade de Filosofia, Ciências e Letras de Presidente Prudente.-

ROSSINI, Rosa Ester

1972 - "Serra Azul: um pequeno centro urbano paulista" - Te se de Mestrado apresentada ao Departamento de Geogra fia da Faculdade de Filosofia, Letras e Ciências Hu manas da Universidade de são Paulo, São Paulo.-

197 - "Contribuição ao estudo do exōdo rural no Estado de São Paulo" - Tese de Doutoramento apresentada ao De partamento de Geografia da Fac. de Filosofia, Letras e Ciências Humanas da Universidade de são Paulo, são Paulo.-

SALGADO, Fernando Carlos Fonseca

$1971^{\circ}$ - "As colonias Bastos e Pedrinhas (Estudo comparativo de Geografia Agrária)" - Faculdade de Filosofia, C C ências e Letras de Presidente Prudente, -

SAUVY, Alfred

s.d. "A população, suas leis de equilibrio (introdução à demografia)" - Livraria Editara Casa do Estudantedo Brasil, Rio de Janeiro.-

TRICART, Jean

1956 - "Contribu1ção ao estudo das estruturas urbanas" in Boletim Geográfico no 153, IBGE, Rio de Janeiro.-

1951 - "L'Habitat Urbaine" - Centre de Documentation Univer sitaire, Paris.-

VEYRET-VERNE, Germaine

1959 - "Population - Mouviments, Structures, repartition" Arthaud - Paris.-

VERA, Armando Asti

1968 - "Metodologia de la Invetigación" - Editorial Kapelusz, Buenos Aires.-

WILHEIM, Jorge

1969 - "Urbanismo no. Subdesenvolvimento" - Editora Saga, Rio de Janeiro.-

ZANELITA, José Henrique

" o conceito bāsico-não bāsico ap̣licado a Laranjal

Paulista" - Inédito.- 


\section{Fontes Cartogräficas}

\section{Plantas Gerais}

- Plantas gerais da cidade de Paraguaçu Paulista, com asnalação dos serviços públicos. Escalas - 1:2.000,1:4.000 e $1: 8.000$. Prefeltura Municipal de Paraguaçu Paulista, 1950, 1958, 1962 e 1974.

- Planta Cadastral da cidade de Paraguaçu Paulista Instituto Geológico e Geográfico, 1938 Prefeitura Municipal de Paraguaçu Paulista, 1949 Cadastro Municipal da Prefeitura Municipal de Paraguaçu Paulista (em elaboração), 1974/75.

- Carta Topogrāfica do Municipio de Paragyaçu Paulista,na escala de 1:50.000

I.B.G.E. - 1974, folha SF-22-Z-A-I-4.

\section{Mapas Gerais}

- Mapa do Municíp1o de Paraguaçu Paulista Instituto Geológico e Geográfico, 1938.

- Mapa do Estado de São Paulo com Municípios Instituto Geolögico e Geográfico, 1923.

- Mapa Geral do Estado de São Paulo Instituto Geológico e Geográfico, 1971.

Fotografias Aéreas

- Levantamento Aerofotogramétrico do Estado de são Pau10, 1962.

- Fotografia aérea no 8.100, do levantamento de 1962, ampliada na escala de 1:5.000 - AEROMAPA do Brasil.,1974.

- Levantamento Aerofotogramétrico do Estado de São Pau10, 1972.

\section{Outras Fontes}

Giannasi, Humberto B.

"Conceição de Monte Alegre, sua histōria e seu passado". Série de artigos publicados no jornal "A Semana" - Paraguaçu Paulista, 1967 e 1968.

Jorge Jünior, José 
Série de artigos sobre a cidade e município de Paraguaçu Paulista, publicados no jornal "A Semana" - Paraguaçu Pau lista, 1967 e 1968.

Arquivo do Estado

Anuários Estatísticos do Estado de São Paulo,1900 a 1939. Cartório da Primeira Circunscrição de Registro Geral e de Hipote cas e Anexos da Comarca de Paraguaçu Paulista.

Centro de Saúde de Paraguaçu Paulista.

Boletins 1960 a 1972 .

Coordenadoria da Ação Regional

Diagnósticos da $4_{-}^{a}, 10 \underline{a}$ e $11_{-}^{a}$ Região Administrativa. Departamento Estadual de Estatística do Estado de são Paulo

Boletins, Anuārios Estatísticos e documentos mimeografados e datilografados - 1940 a 1969.

Enciclopédia do Municípios.

Estrada de Ferro Sorocabana

Relatórios do período de 1916 a 1940.

Fundação Plano de Amparo Social

Levantamento sócio-econômico das populaçōes marginais do Estado de São Paulo - Região de Presidente Prudente,1969.

Hospital de Caridade de Paraguaçu Paulista

Relatórios da entidade do períoda de 1948 a 1973.

Instituto Brasileiro de Geografia e Estatística

Censos de 1920, 1940, 1950, 1960 e 1970.

Instituto Panamericano de Geografia e História

Comissão de Geografia

Textos Básicos 1 - Centralidade e Regionalização. Vários autores, julho de 1968.

Ministério da Indústria, Comércio, Viação e Obras püblicas

Sinopse do Recenseamento de 1900.

Prefeitura Municipal de Paraguaçu Paulista

Livros de Registros de Imposto sobre Indústrias e Profissóes.

Modelos "A" e "B" das Declarações de Dados Informativos Necessários à Apuração dos Indices de Participação dos Mu nicípios Paulistas no Produto de Arrecadação do ICM,1974. Relatório da VIII Caravana ABENIBRA (Associação Nipo-Brasileira de Estudantes de Medicina) 18/01/73 a 28/01/73 - Paraguaçu Paulista.

Secretaria da Agricultura, Indụstria e Comércio do Estado de são Paulo 
Escatítica Agrícola e Zootécnica - 1930 a 1939.

Secretaria de Economia e Planejamento do Estado de são Paulo

Cadastro Bancário, 1972 e último trimestre de 1973. 
A N E X O S 


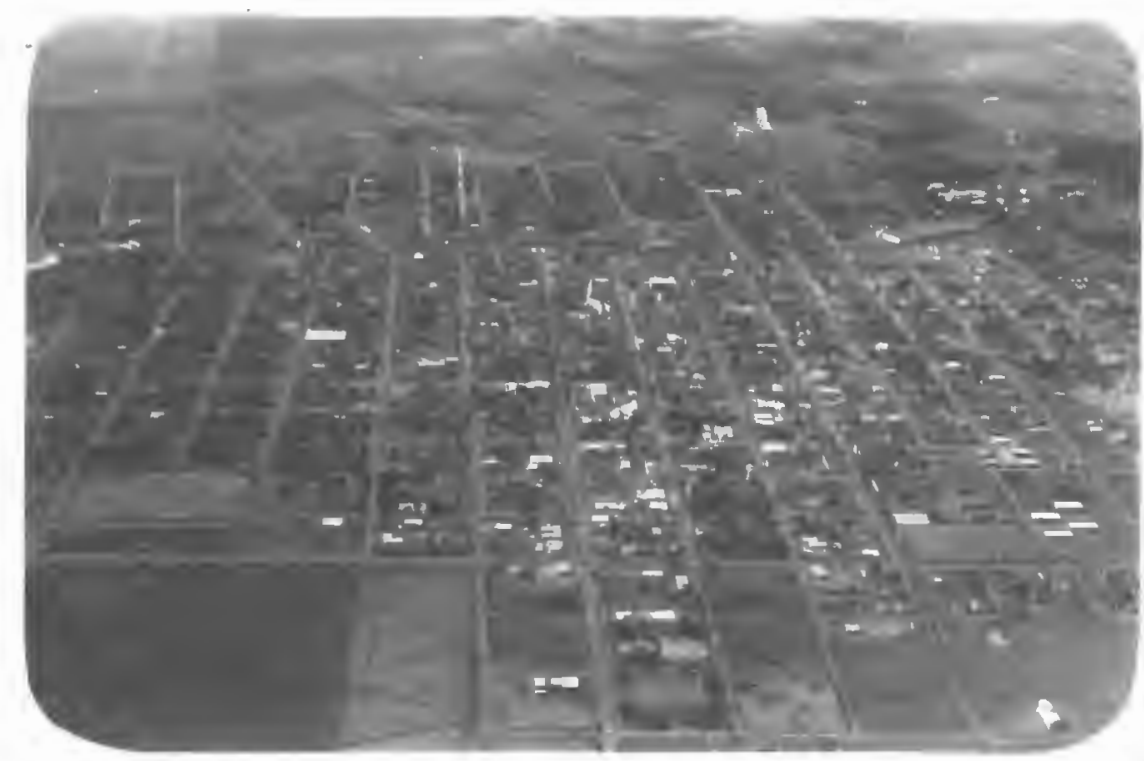

Foto 1. - Vista geral da cidade na direção oeste-1este, mostando o traçado quase que essencialmente retilíneo e perpendicular das ruas, evidenciando o plano en tabule ro de xadrez do núcleo urbano.

No primeiro plano a Avenida Galdino marca o espigão divisor dos Ribeiróes do Alegre (leste - ao fundo) e do Sapé (oeste -ärea em início de ocupação).- Foto José Martin Suarez.

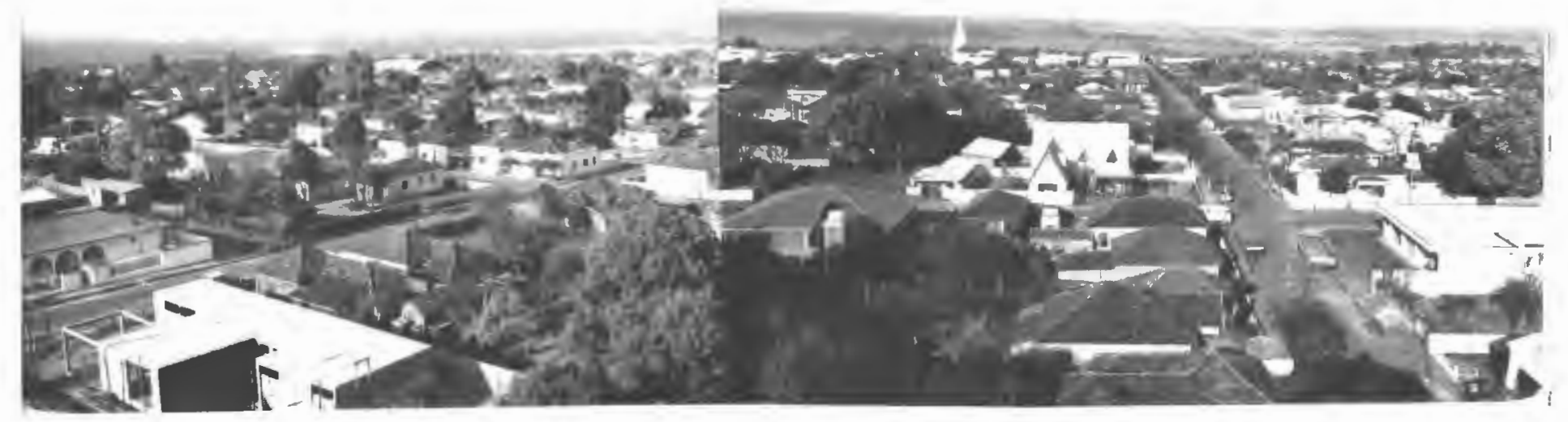

Foto 2.- Vista do espaço urbano na direção E.NE., a par tir do espigão divisor dos Ribeirões do Alegre e Sapé. o espaço caracteriza-se pela uniformidade da arquitetura dos imóveis residenciais, revelando a tênue comparti mentação socio-econômica da população.- Foto José Martiñ Suarez. 


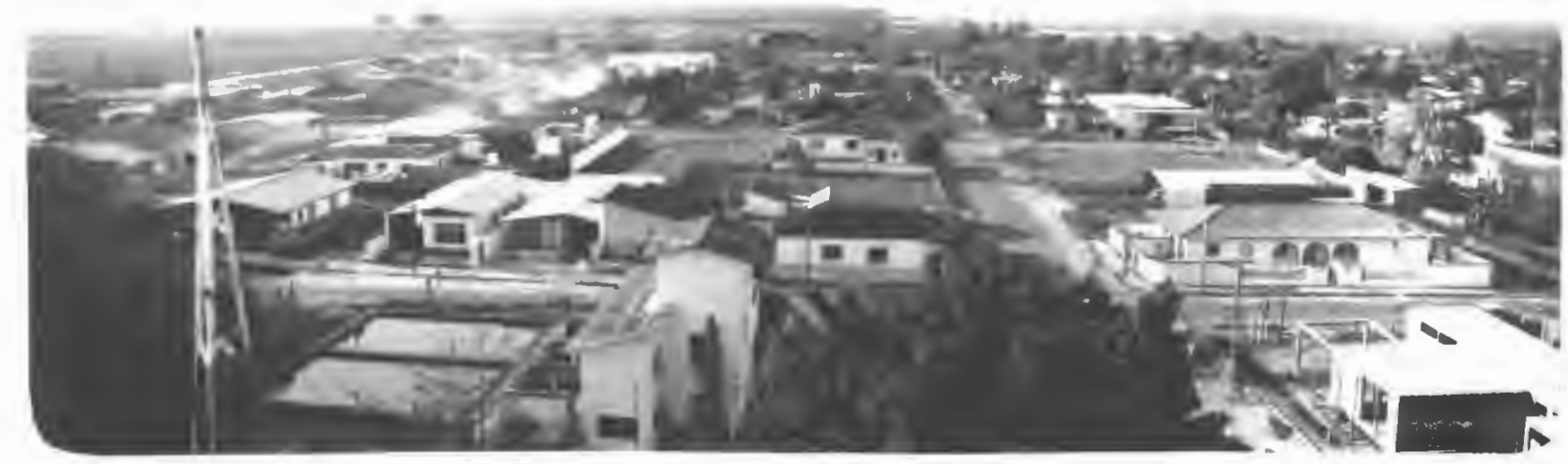

Foto 3.- Extremo 0.NO. da cidade. Area de expansão recente e de atração de investimentos proporcionados pela concentração de rendas advindas pela presença de população melhor aquinho ada econômicamente neste setor urbano. As edificações, ocupañ do terrenos mais espaçosos, são amplas, com melhor acabamen to e com plantas dentro de um conceito mais moderno e racio nal de aproveitamento. Foto José Martin Suárez.

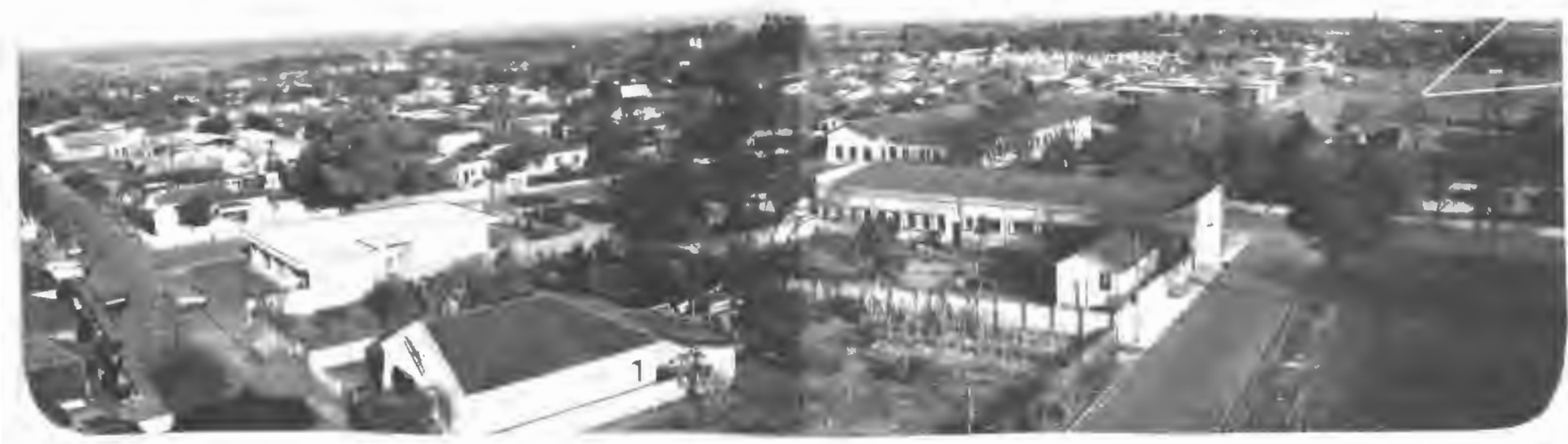

Foto 4.- Extremo S.SE. da cidade, evidenciando a extrema pla nura do sítio urbano na direção sul. Este fato se verifica $T$ igualmente para a dirç̧ão norte; demonstrado pela foto 3.ocupando todo quadro dircito da foto encontra-se os estabele cimentos de ensino da Fundação Gammon: Colégio Comercial e Escola Superior de Agronomia.- Foto José Martin Suárez. 


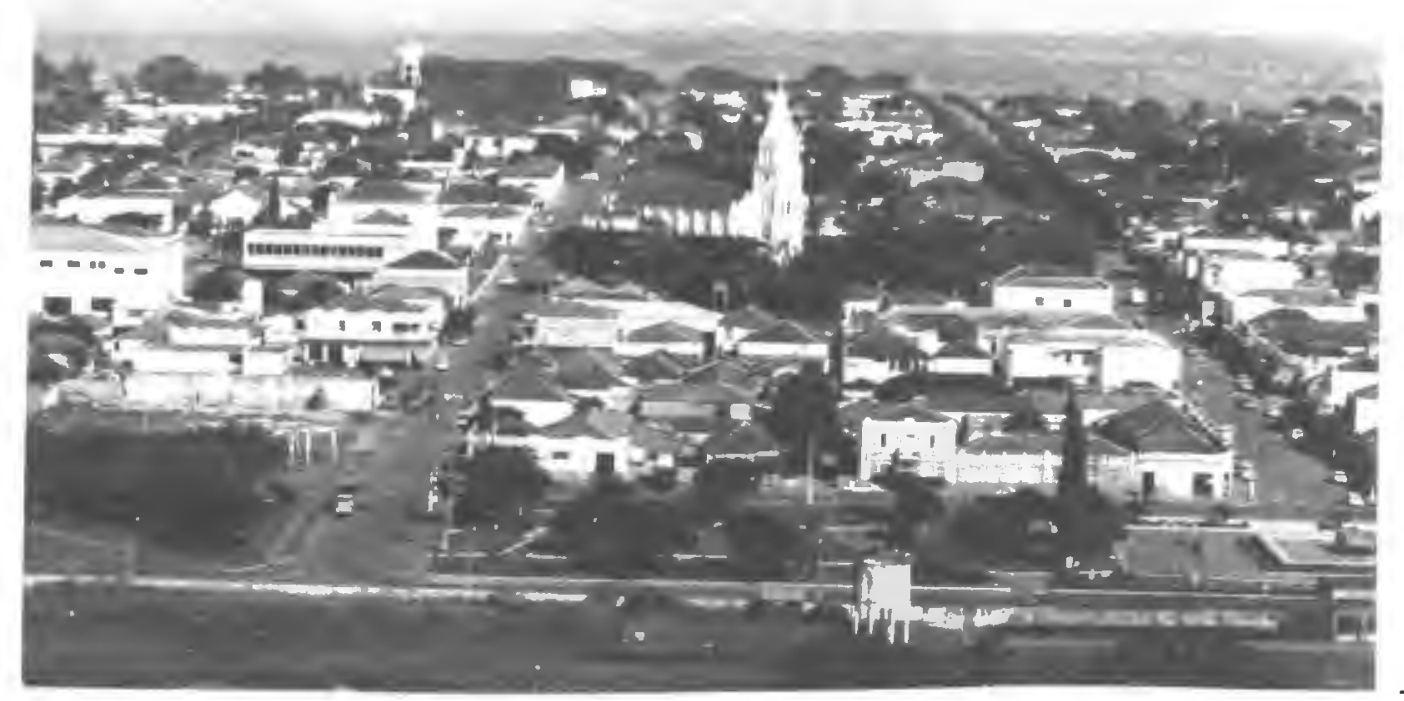

Foto 5.- Ārea antiga é central, onde as construçōes são, na maioria, para fins comerciais e de serviços, e que se abrem diretamente sobre as ruas. os seus es paços livres constituem estreitos corredores entre os edifícios. No primeiro plano a ferrovia (FEPASA) e partc da Praça João XXIII. No centro a Praça 9 dé Julho, com a Igreja principal da cidade. Foto José líazin șuárez.

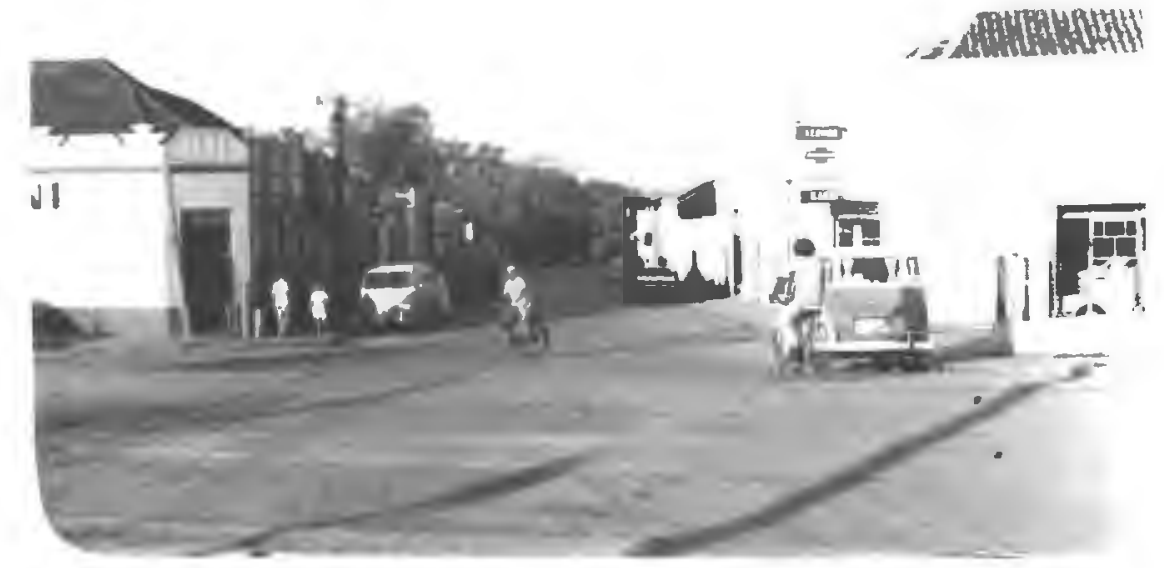

Foto 6.- Primeira quadra da rua José Salomaona Barra Funda, direção Oeste-1este.o seu pequeno centro comercial apresenta morfologia que guarda as mesmas caracterís ticas da área central. Alguns destes imóvēe is datam dos primeiros años da cidade. $\bar{A}$ maioria deies têm nos fundos a presença de residência do proprietário. Foto José Mar tin Suárez.- 


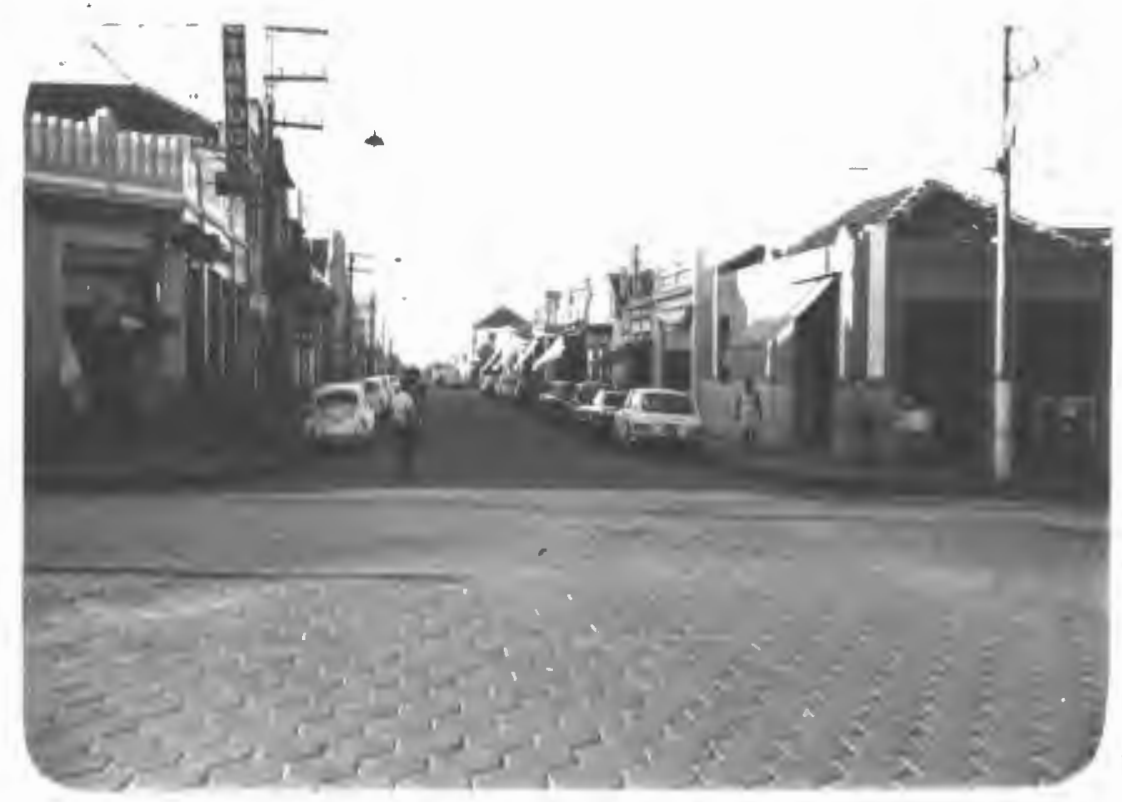

Foto 7.- Trecho norte da rua 7 de Setembro a partir da Avenida Paraguaçu. Constitui parte do "centro" da cidade onde se verifi ca a coucentração da atividade comercia1. A foto mostra a face esquerda da rua 7 de Setembro, contida na figura 9.(pag. 164).Foto José Martin Suárez

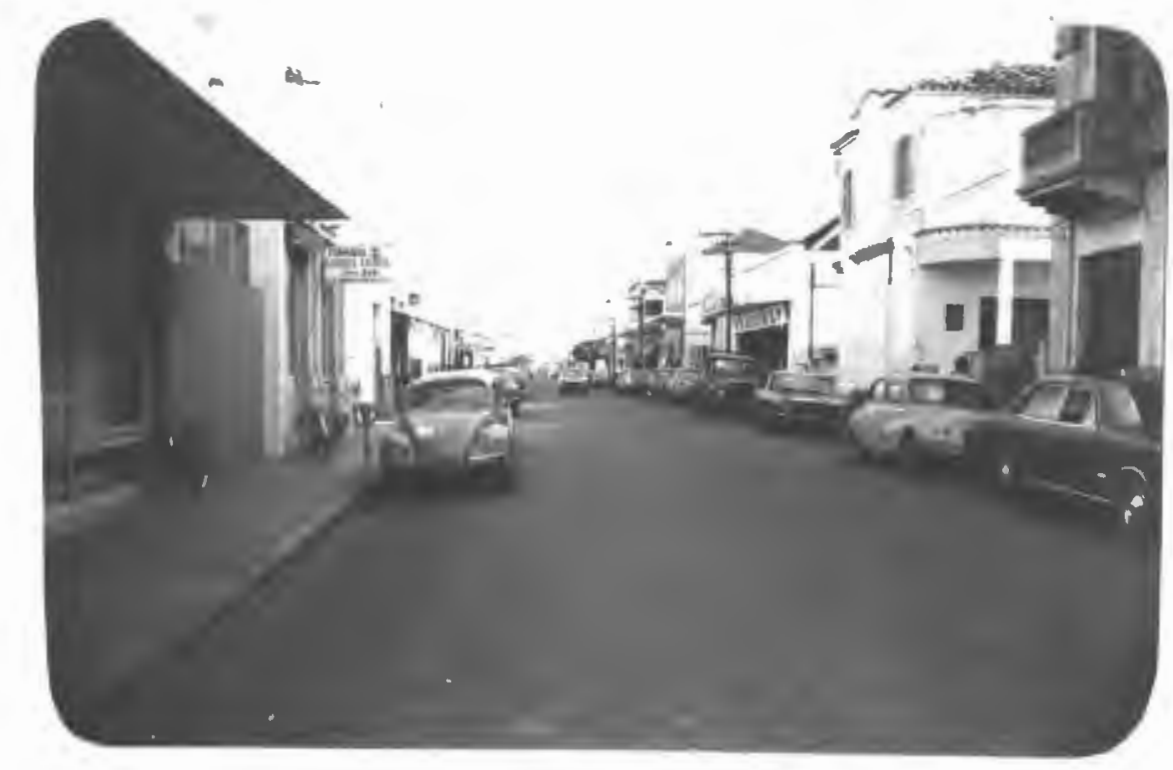

Foto 8.- Parte sul da rua 7 de Setembio, a partir da Avenjsla Paraguaçu, onde o primei ro plano integra a ärea central da cidade. Verifica-se o dominio de imóveis voltados principalmente para o comércio, embora esta atividade c os serviços extravasemo cen tro, pontilhando estabelecimentos ao longo desta rua. A foto confirma a pequena decil videde do sítio urbaro, demonstrada no per fil "ln" (sul-note), figura 8, pab. 16i.Foro José iartin suárez. 


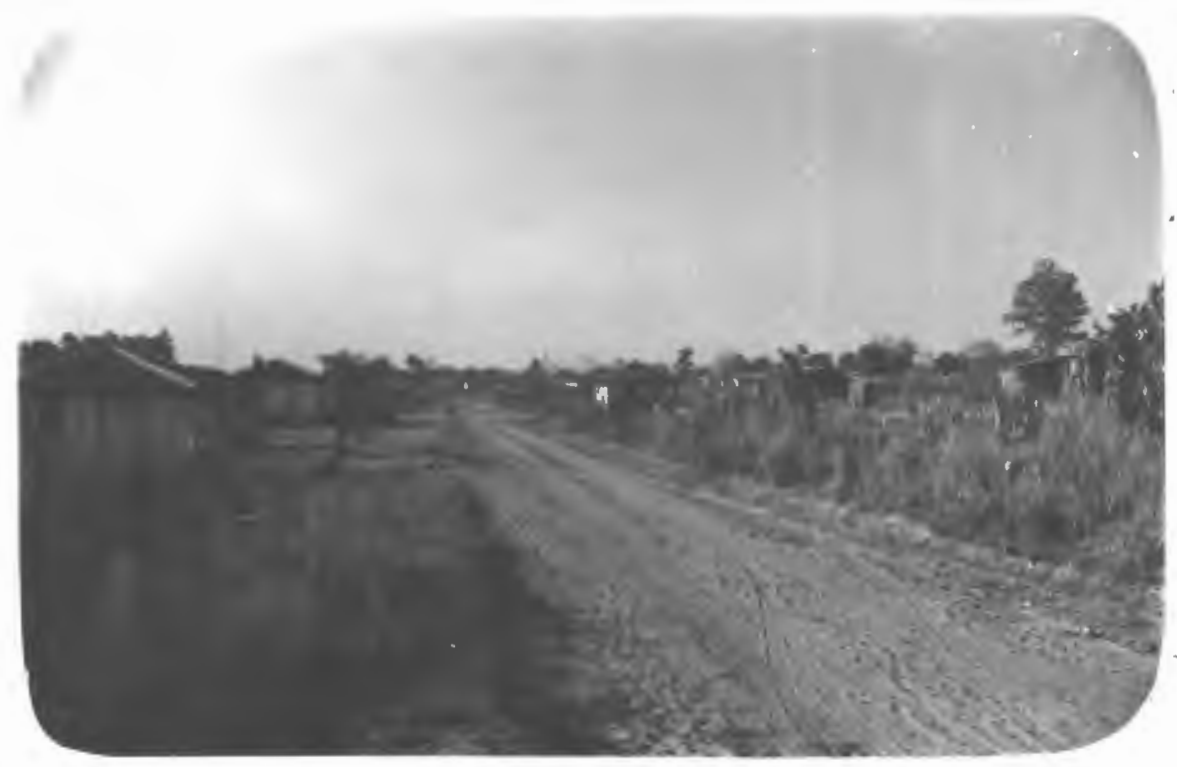

Foto 9.- Trecho da rua Amazonas, na Vila No va, setor da cidade cuja característica priñ cipal é a função de residência de população com poucos recursos economicos e na sua mai oria de origem rural - o bóia-fria.-

Foto José Marin Suárez.

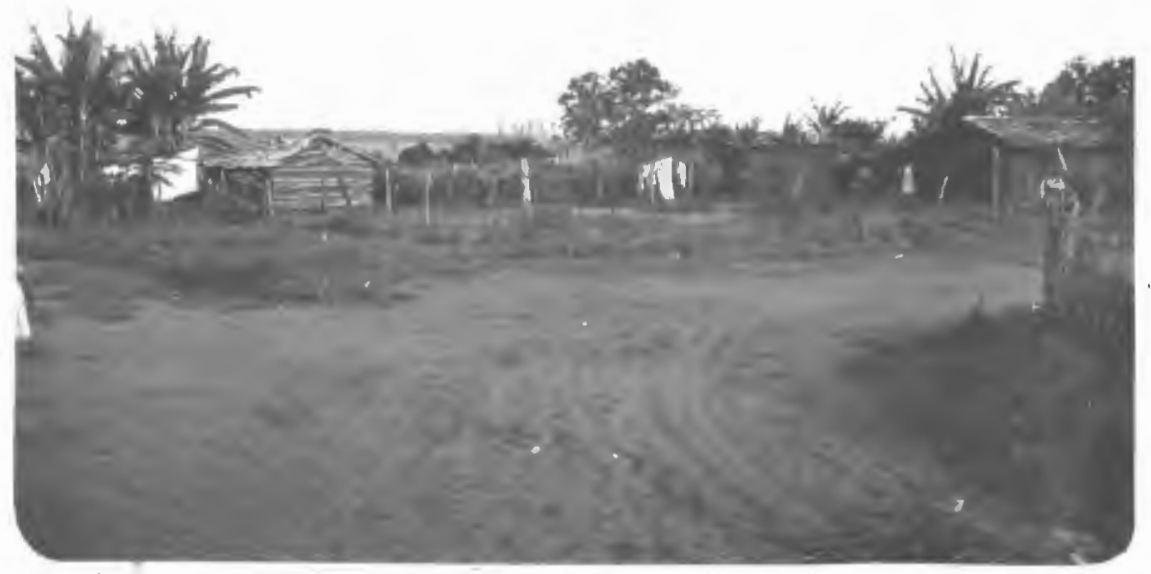

Foto 10.- Trecho da periferia da cidade, na Barra Funda, onde dominam as habitaçoes de madeira já desgastadas; de barrote ou bar racos armados com madeira velha ou de ca $\bar{i}$ xotes, cobertas com sapé, follas de zinco ou semelhantes e já deterioradas pelo tempo ou con telhas velhas recolhidas dos restos de demuitções. A população que as ocupa, é paupérrima e vincula-se as ativjdades sazoná rias do campo - o böia-fria.- Foto JosëMar tin suárezz. 


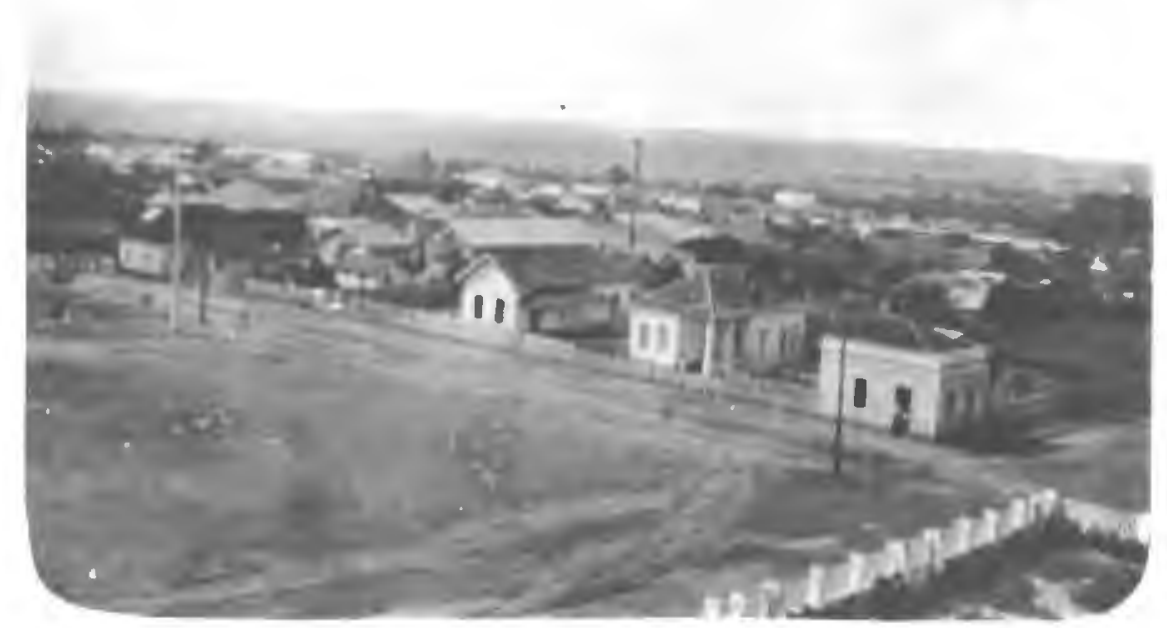

Foto 11.- Trecho da rua 15 de Novembro, a partir da rua Irmā Gomes, em frente à Pra ça 9 de Julho, no início da década de 1930 . Foto cedida por José Jorge Jünior.

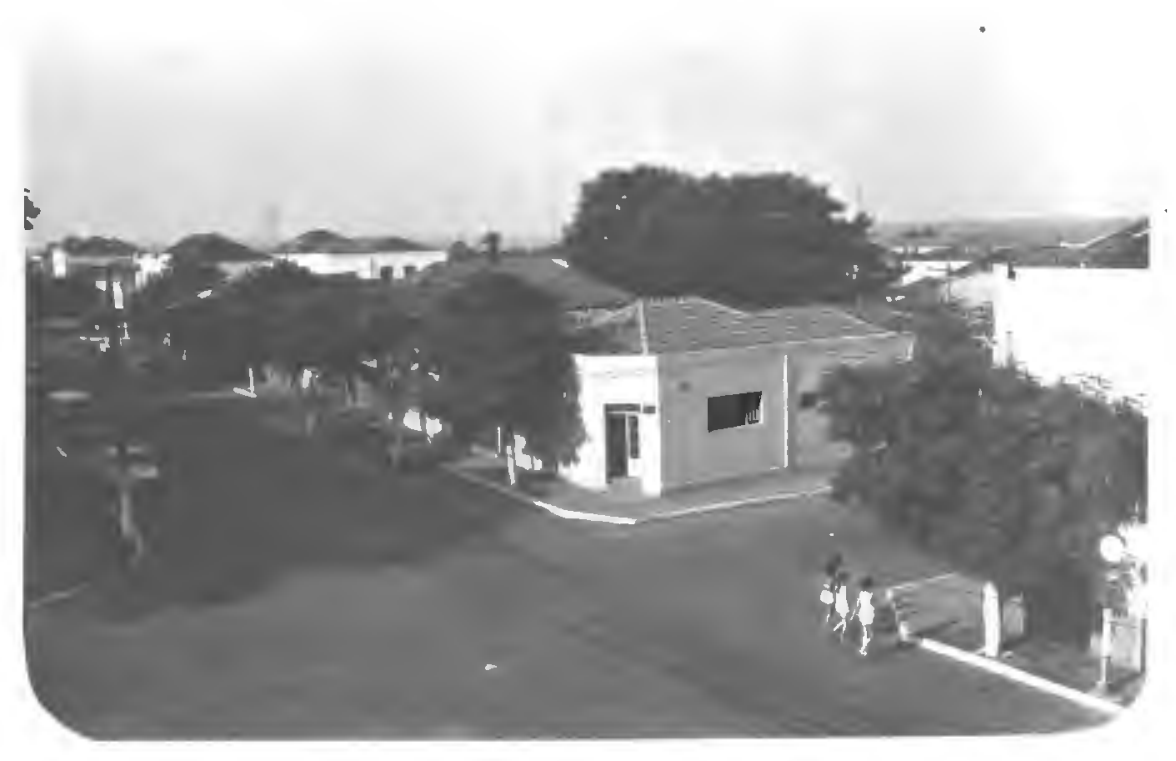

Foto 12. - Trecho da rua 15 de Novembro, a partir da rua Irmã Gomes, em frente à Pra ça 9 de Julho, em 1976. As construções guar dam as mesmas 1 inhas da arquitetura dos anos 30 . Comparada a foto 11 , a grande. transformação constitui a presença do equi transformaça púbico. Foto José Martin Suárez 


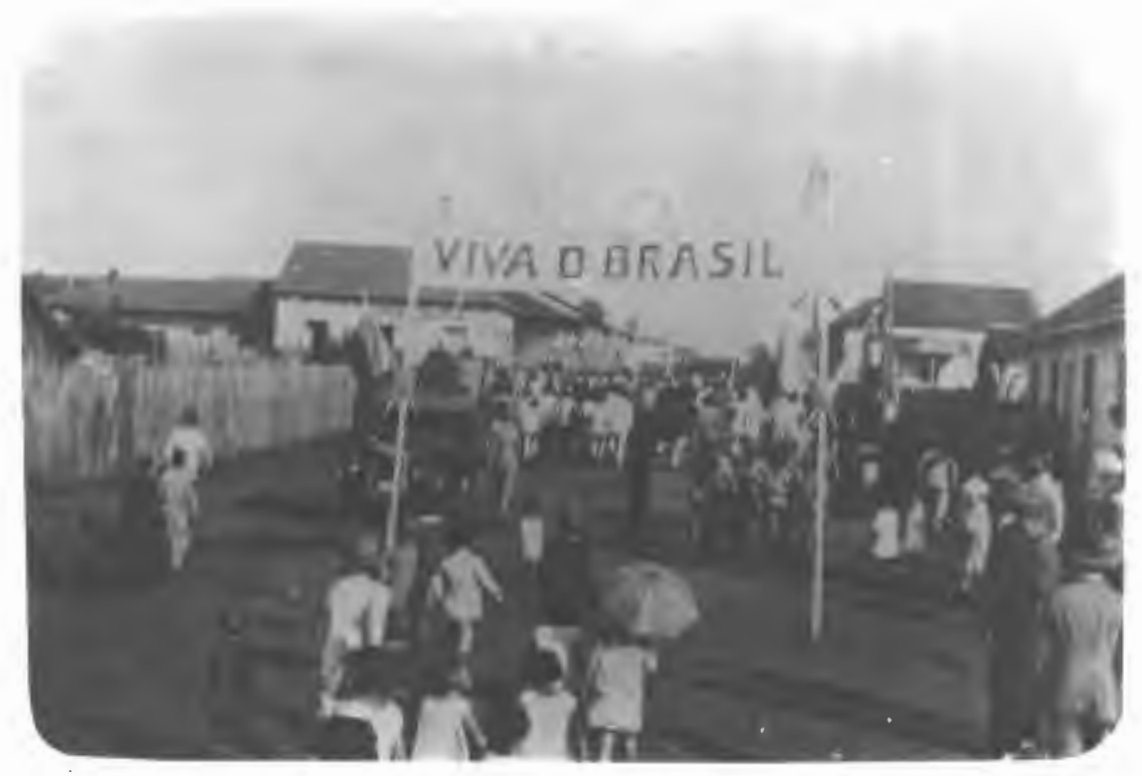

Foto 13.- Primeira quadra da rua José Sa lomao, a partir da Avenida Gago Coutinho, na direção leste-oeste - Barra Funda.A fo to retrata os fins da década de 1920.

Foto cedida por José Jorge Júnior.

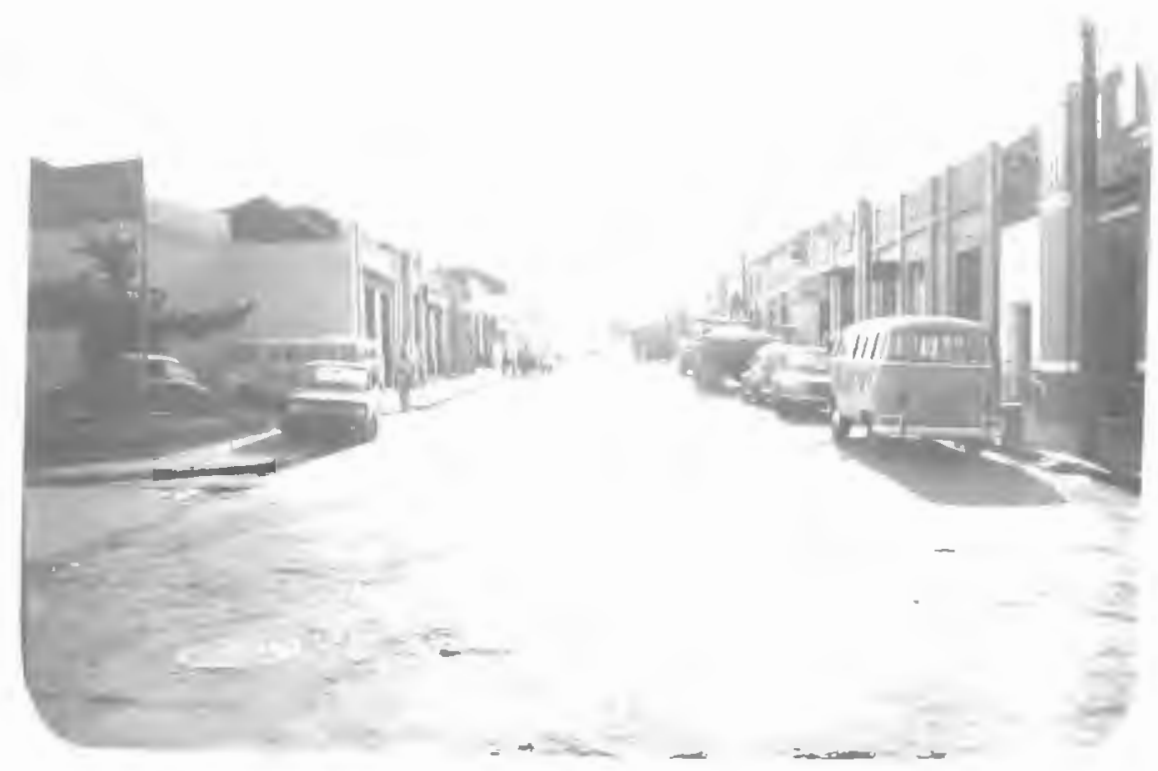

Foto 14.- Primeira quadra da rua José Sa lomao, a partir da Avenida Gago Coutinho, na direção leste-oeste - Barra Funda. A foto data de 1976. Constitui um dos primei ros trechos abertose ocupados pela cidade (foto 13), sendo que alguns imóveis ainda conservam a arquitctura inicia1. Foto Jo sé Martin Suárez. 


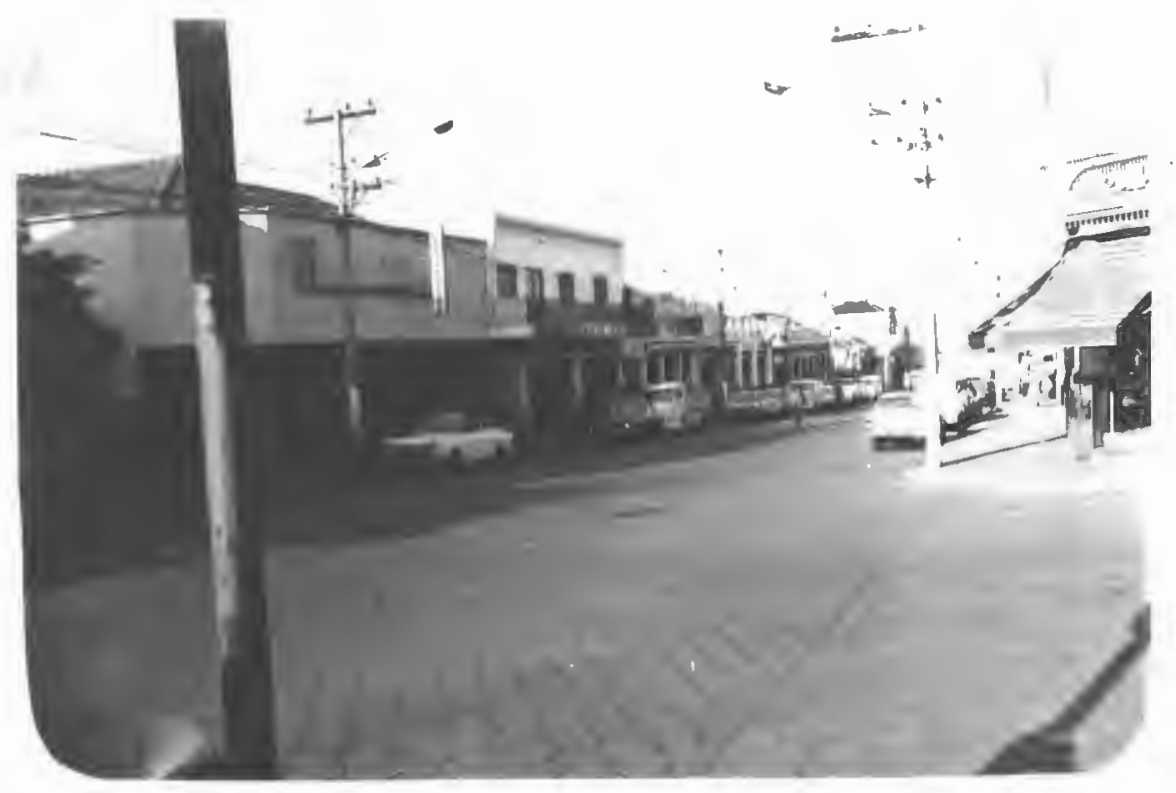

Foto 15.- Trecho da Avenida Paraguaçu, principal artéria da cidade, em dire ção leste, a partir da Praça 9 de Jü 1ho. Constitui parte do "centro" onde se verifica o domínio quase que absolu to da atividade comercial. Pavimentaçăo tipo "blokret". Foto José Martin Suárez

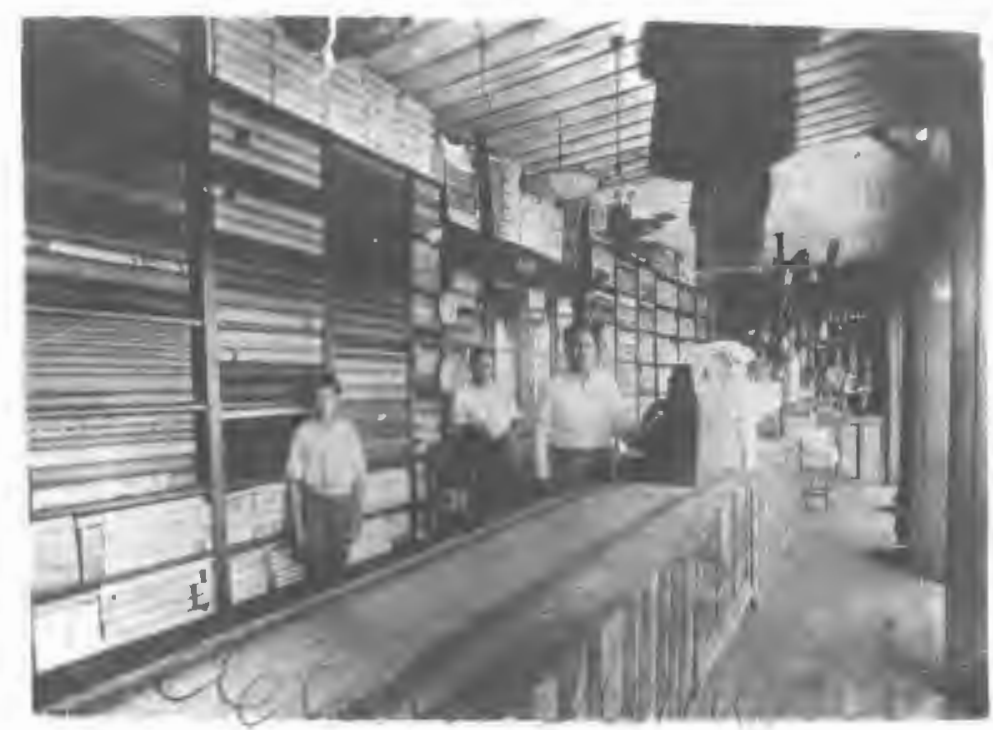

Foto 16.- Casa comercia1 fundada em 1921. (a foto data de 1928), com seu variado sor timento: tecidos, armarinhos, chapéus (no primeiro plano), calçados, ferramentas e utensílios domésticos (plano de fundo). Foto cedida por Wilson Zauhy. 


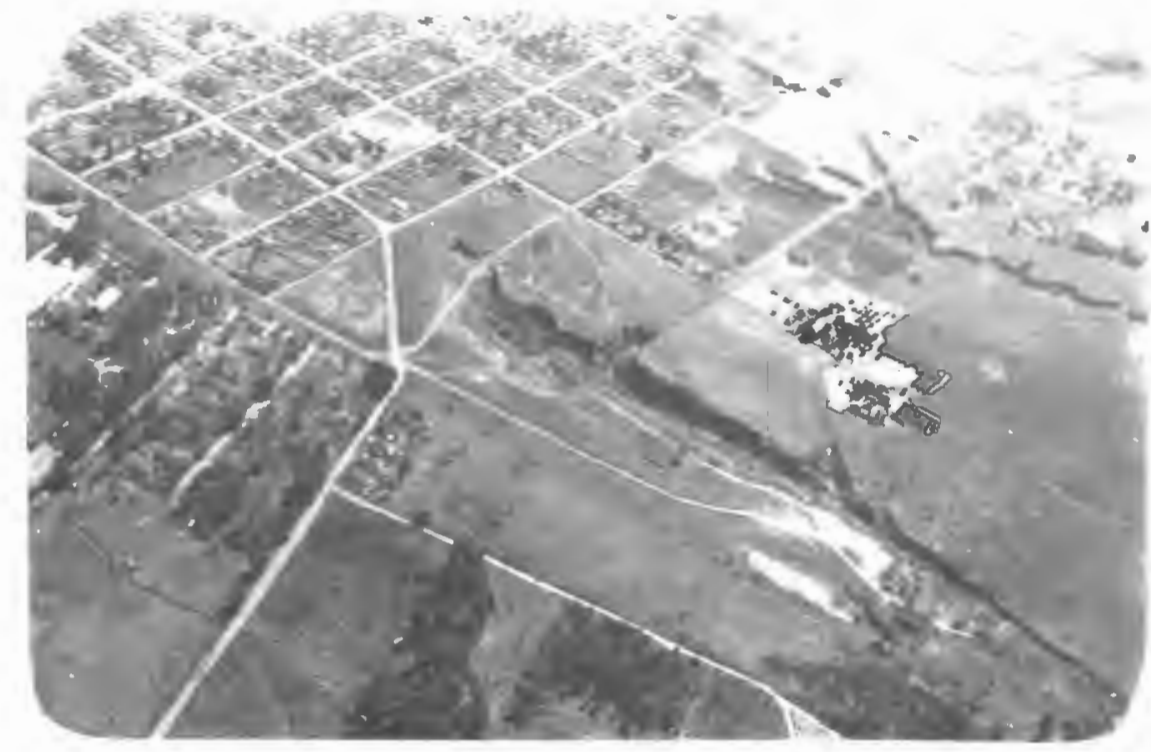

Foto 17. - Vista da parte leste da cidade, onde se pode observar tres vossorocas nos sedimentos pós-Bauru, cujas presenças cons tituíram impedimentos à expansão do núcleō urbano nessa área. Foto Marcio Antonio Tei xeira.

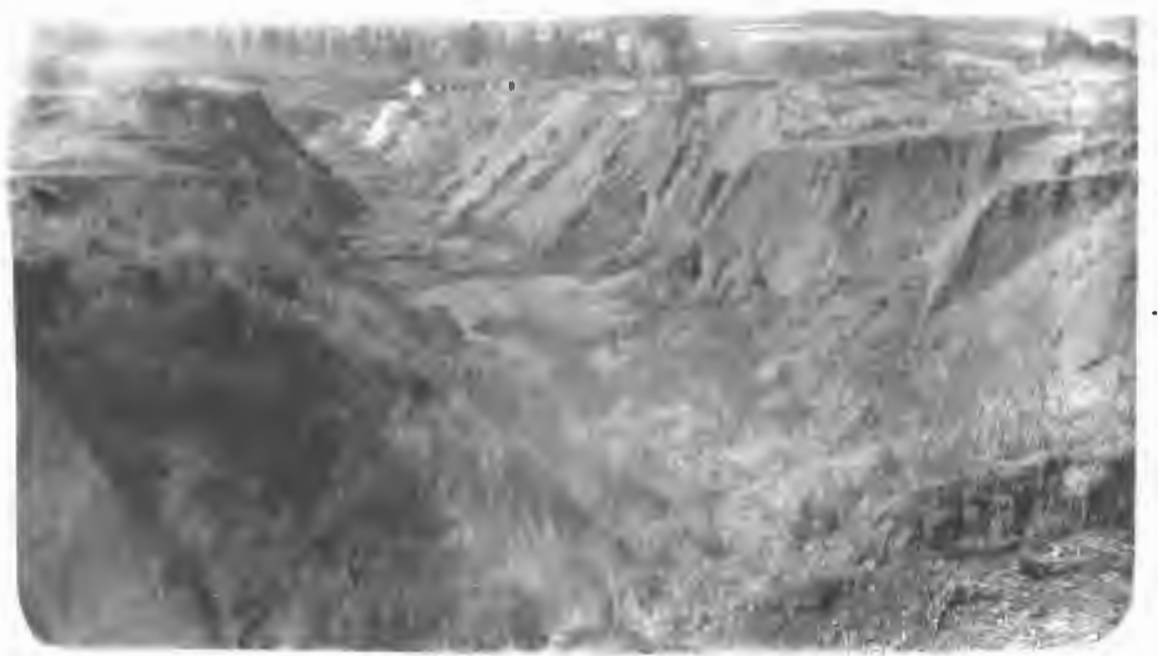

Foto 18.- Voçoroca na vertente do Ribeirão do Alegre, a leste da cidade. 


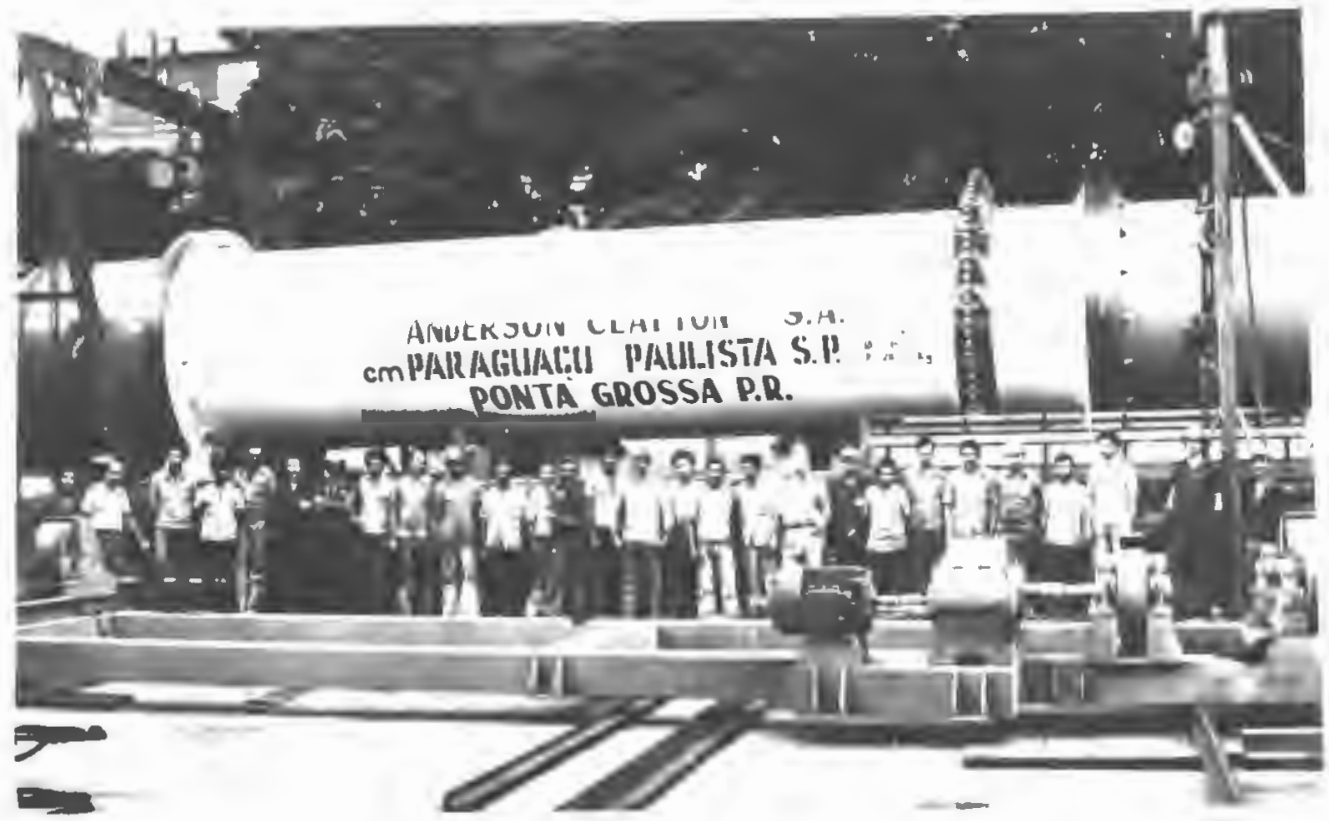

Foto 19.- Secador para farelo de soja, construído na "oficina" da Anderson Clayton de Paraguaçuau 1 ista. Constitui parte do equipamenco para a gran de unidade irdustrial da empresa, cm montagem, eri Ponta Grossa (PR). Foto cedida por Aldo Distrutti. 
Rua

CASA

Tércea__ Bobrado___ Alvenaria__ madeira

Induštria e residência

financiada valor do

com asfalto rista barraco

energia elētrica R. de esgôto Comércio e residência idade da casa própria a lugada profissão do proprietārio possui fogão à gaz geladeira_televisão tādio rádio. rádio-vitrola enceradeira outros QUAL E O RENDIMENTO MEDIO MENSAL DA CASA?Cr\$ onde os adquiriu

Abastecimento e serviços

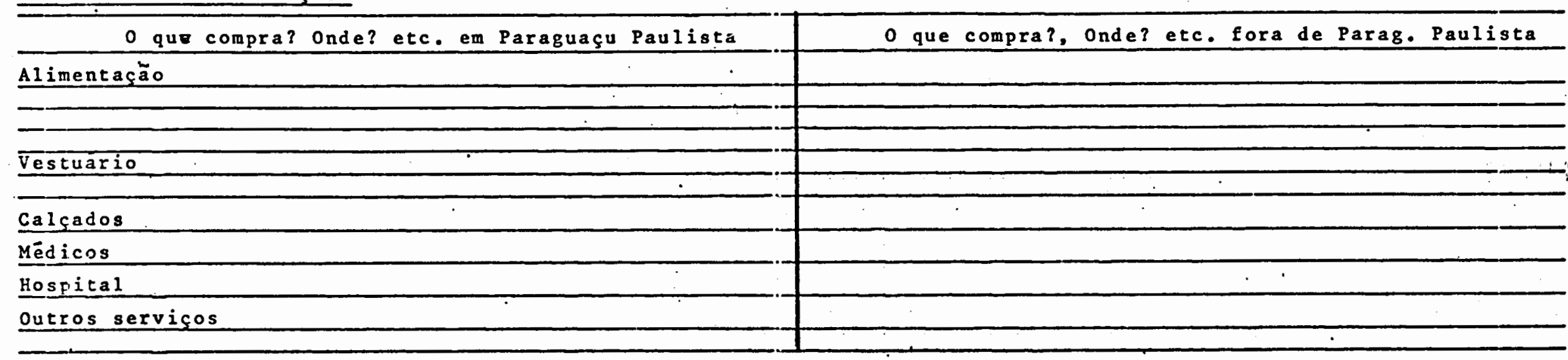

Quais os problemas que encontra no abastecimento? tem sugestões?

Lê e assina jornais? Quais? Qual é a rädio que mais ouve? Qual é a ocupação nos dcringos e feriados? Onde vai?

Observaçōes

(Áplićado_en $\underline{500}$ residêñías - 1971$)$ 


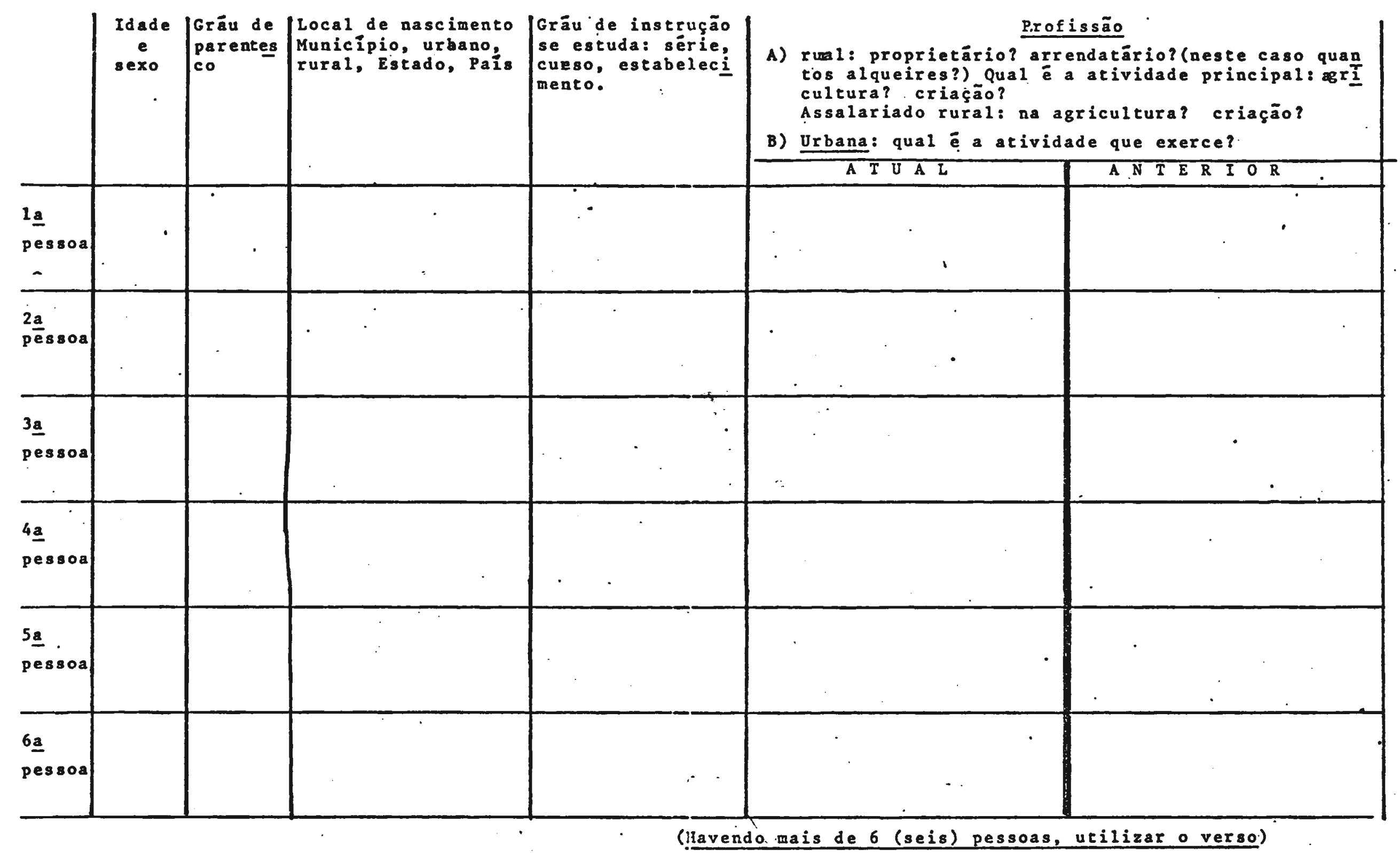




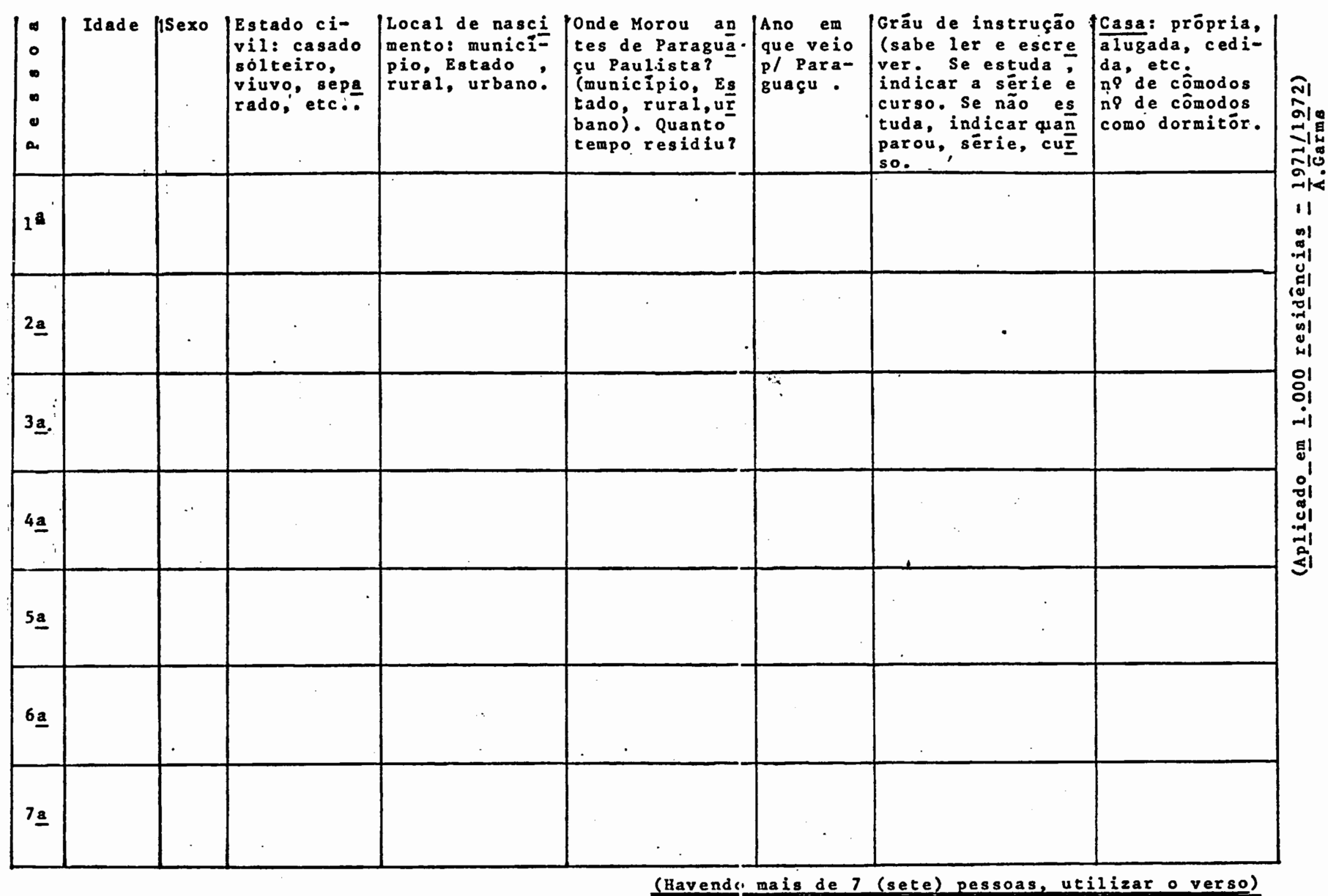




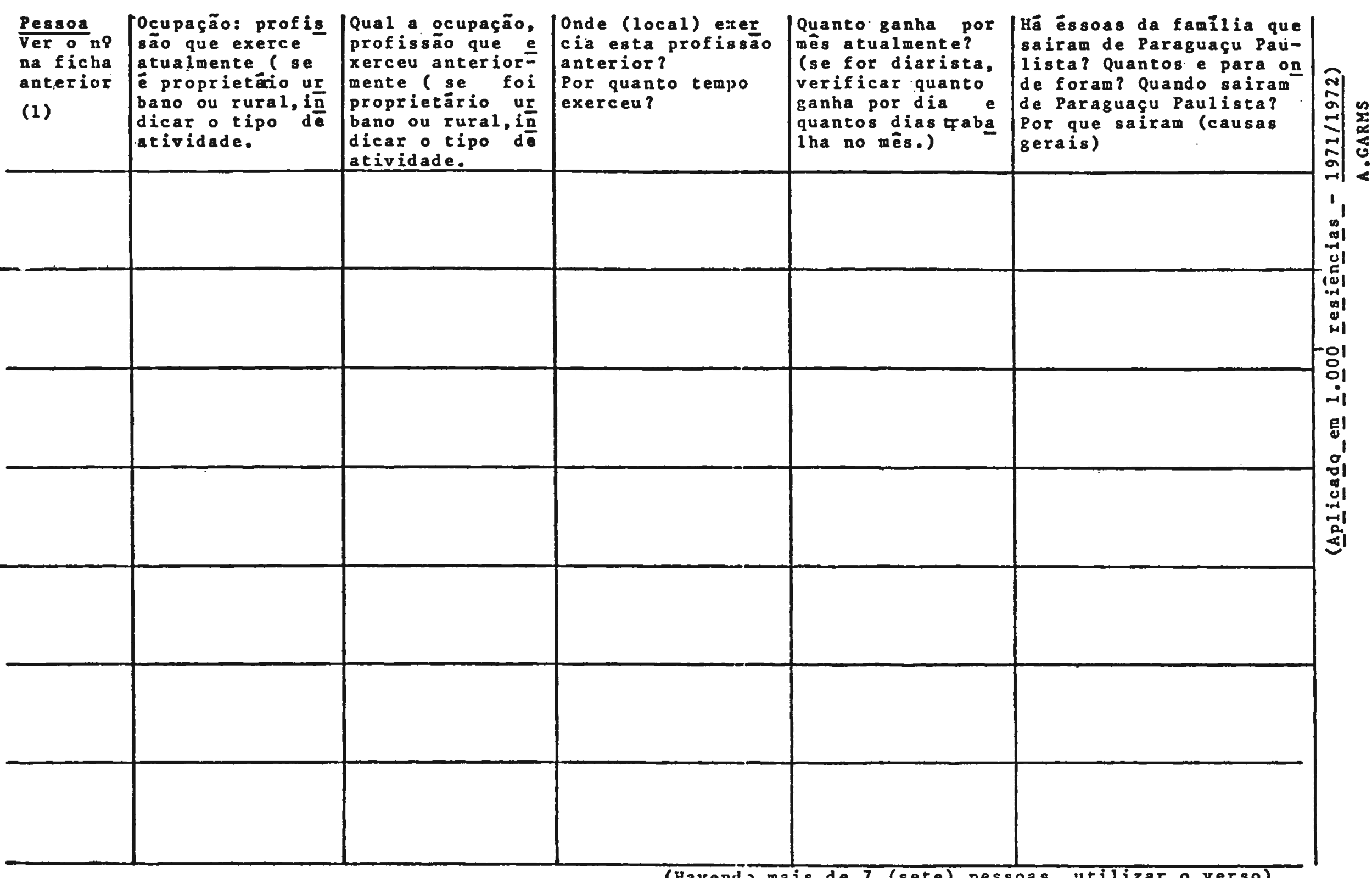




\section{Tipo de indústria}

Enderêço

Construção: Madeira

Area construída

Razão social

Inpicio das atividades

Seç̧ōes que a indústria possui:

Comparaçao da indústria no ambito municipal, regional e sub-regional:

\section{Matéria Prima}

\begin{tabular}{l|l|l|l|l}
\hline Matéria prima & valor & Procedéncia - região \% & Ton. ou quantid. \\
\hline & & A B C D E F G H I J K L M N & \\
\hline & & & \\
\hline & & & \\
\hline & & & \\
\hline & & & & \\
\hline & & & & \\
\hline & & & & \\
\hline
\end{tabular}

Observações:

Variação sazonária da matēria prima: (verificar se varia a procedência da matéria prima segundo os diferentes períodos do ano. Indicar a situacã $)$. No Asfalto Térrea_sobrado idade da constr. Area do terreno 
(fols. 3)

\section{RIPO. DE VENDA}

vista

Prazo $\%$

Diajantes 7

Representantes \% Atacadistas $\%$

Diretamente Depósitos F Outros $\%$

Causas da preferência do consumidor (sistema de vendas/prêçolqqualidade/ entrega pontual/prazos/ etc..)

EVOLUÇÃo

R) Matēria Prima:-

b) Produtos:

E) Crescimento da produção:

1) Mercado Consumidor:

P) Perspectivas (mercado e produção): 


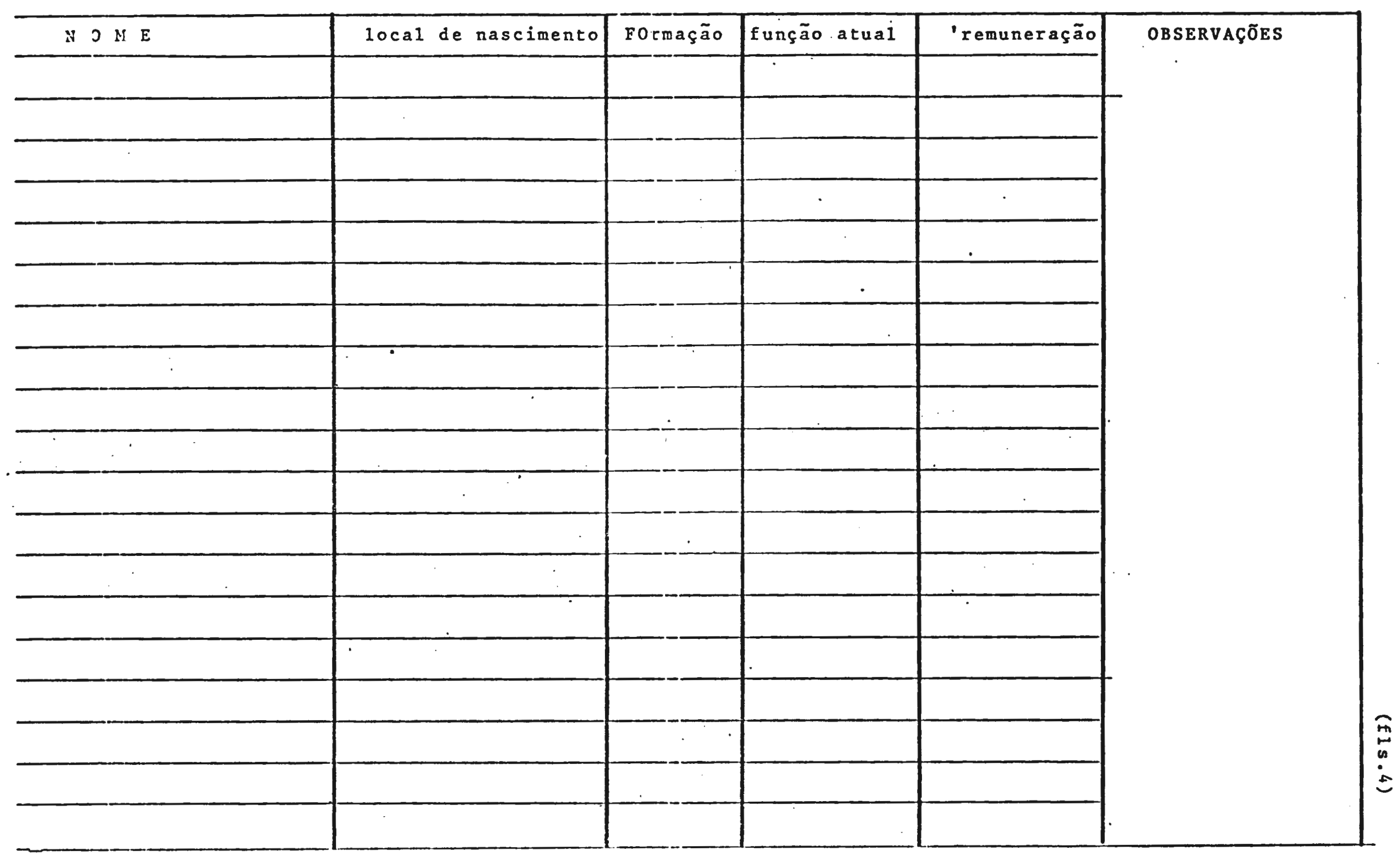


Evolução do ni de empregados:

Valor mensal da fôlha de pagamentos:

Mão-de-obra sazonária: (número/ época dé emprēgo/função que exercem/tem po que permanecem/o que fazem no perído de eñ tre-estações, etc..)

\section{EQUIPAMENTO:}

\begin{tabular}{|c|c|c|c|c|}
\hline Tipo & Local de Eabricação & $\begin{array}{l}\text { ano de } \\
\text { aquisição }\end{array}$ & $\begin{array}{l}\text { Capacidade } \\
\text { utilizada }\end{array}$ & Observações \\
\hline & 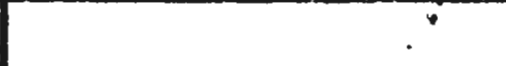 & & & \\
\hline & & & & \\
\hline & & & & \\
\hline & & & & \\
\hline & & & & \\
\hline & & & & \\
\hline & & & - & \\
\hline
\end{tabular}

\section{ENERGIA}

Tipo de energia utilizada:

Consumo mensal

Kwh ou o equivalente em $\mathrm{Cr} \$$

Motores existentes: Tipo

Potência

Utilização

\section{Observações:}




\section{STORICO PROFISSIONAL DO PROPRIETARIO}

1- Avós: Onde nasceram? Onde residiram antes de Paraguaçu Paulista? Por que vieram para P. Paulista? O que faziam anteriormente?

Quạis as atividades que exerceram em P.Paulista?:colonos, I Assalariados, proprietärios, comerciantes, etc.? (Verificar as causas de mudanças de atividades e as épocas, se possivei

2- Pais: İdem aos avós

3- Proprietário: Local de nascimento. Onde residiu antes? (as värias residencias). Suas profissóes anteriores; Sua profissão atual causas das mudanças de profissōes. O que o levou a estabele-

cer-se no ramo atual. Origem do capital. Possui outras pro priedades? Tipos? 0 que o levou a adquiríląs?.

Perspectivas futuras quanto ao seu estabelecimento em parti cular? (mudanças de profissä́, de ramo de negócio, etc.. Caū sas.)

Gráu de instrução. 
A - Município de Paraguaçu Paulista

B- Sub-Regiāo de Assis : Assis, Borá, Candido Mota, Campos Novos Pau 1ista, Cruzalia, Florínea, Ibirarema, Lutécia, Maracai, Palmital, Platina, Quatá:

C - Sub-Região de Marilia : Aluaro de Carvalho, Alvinlândia, Echaporã, Galia, Garça, Lupercio, Ocauçu, Oriente, Oscar Bressane, Pompéia, Quintana, Vera Cruz.

D - Sub-Região de Ourinhos: Bernardino de Campos, Chavantes, Fartura, Ipauçu Manduri, Oleo, Piraju, Ribeiräo do Sui, Salto Grande, Santa

Cruz do Rio Pardo, São Pedro do Turvo, Sarutaīá, Taguaỉ, Tejüā.

E - Sub-Região de Tupã: Bastos, Herculândia, Iacri, Queiróz

F - Sub-Regiōes de Pregidente Prudente e Presidente Venceslau: Alvares Machado, Alfredo Marcondes, Anhumas, Caiabu, CAiuá, Estrêla do Nor té, Iepê, Indiana, João Ramalho, Martinópolis, Maraba Paulista, Mi rante do Paranapanema, Narandiba, Rirapózinho, Piquerobi, Presiden te Prudente, Presidente Bernardes : Presidente Epitácio, Presidente Vencéslau, Santo Anstácio, Teodoro Sampaio

G - Região da Alta Paulista: Adamantina, Flora Rica, Flórida Paulista, Dracena, Irapuru, Junqueirópolis, Lucélia, Mariápolis, Monte Caste 10, Nova Guataporanga, Ouro Verde, Osvaldo Cruz, Pacaembu, Panorama Parapuã, Paulicéia, Rinópolis, Sagres, Salmourão, São João do Pau DAlho, Tupi Paulista; Santa Mercedes.

-H - Região de São Paulo - Capitál.

1 - Kestance do Estado de sãu F́auju.

J - Estado do Mato Grossot

K - Estado do Paraá.

L - Outros Estados.

K - OUtros Países. 
Pesquisa comercial e dos Serviços = Paraguaçu Paulista

Tipo de Comércio ou serviço

Enderêço:

Construção: Madeira

MIsta

Alugada

Alvenaria Asfalto

Prōpria

N9

Sobrado

Início das atividades

Razão Social

Seções que o estabelecimento possui

Filiais (discriminar os estabelecimentos e localiza ções:

CENTROS DE ARASTECIIENTO

(indicar o local de procedéncia, rural ou urbano, o Estado, o país)

\begin{tabular}{l|l|l|l|l|l}
\hline Produtos & $\begin{array}{l}\text { Quantidade } \\
\text { mensal/anua }\end{array}$ & Procedência & $\%$ & Transporte & $\%$ \\
\hline & & & & & \\
\hline & & & & & \\
\hline
\end{tabular}

COMPLETAR ESTE_QUADRO COM AQUELE_DA FL $-\underline{S}$

Acréscimo do frete sôbre o valor dos produtós (em \%)

Variação sazonária do abastecimento: (verificar a variação de proceden cia cios produtos, sequndo os periodos do ano. Indicar as causas)

Sistema de vendas

Possui viajantes Quantos?

Vendas à vista \% na zona urbana

vendas à prazo \% na zona urbana

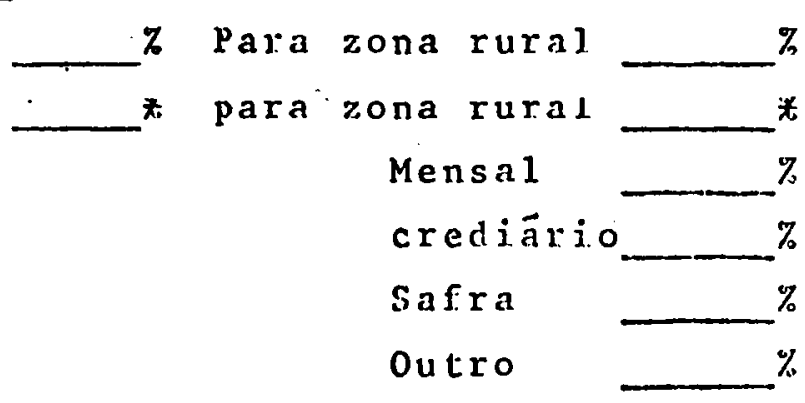


Valor médio mensal de vendas Cr\$

sistema de entrega de mercadorias ou prestação de serviços

MERCADO CONSUMIDOR (comércio ou serviços)

\begin{tabular}{|c|c|c|c|c|}
\hline Produtos & Centros consumidores & $\begin{array}{c}\text { urbano } \\
7\end{array}$ & $\begin{array}{c}x \text { uxa } 1 \\
7\end{array}$ & Estadp \\
\hline & . & . & & \\
\hline & $\cdots$ & & & \\
\hline & & & & \\
\hline & & & & \\
\hline & & & & \\
\hline & & & & \\
\hline & & & & \\
\hline & & & & \\
\hline & & & & \\
\hline & & - & & \\
\hline & $\because$ & $\cdot$ & $\cdot$ & \\
\hline & & & & \\
\hline & . & & & \\
\hline & & & & \\
\hline & & & & \\
\hline
\end{tabular}

(Se necessärio use o verso)

Considerações Gerais (anotar em fồha ànexa) $\therefore$ :

1. Evolucão do estabelecimento: Já existia? 0 que faz atualmente o an tigo proprietario? Como começou o estabelecimento?péqueno, médio, grande? Houve mudanças no tipo de comércio, isto $\bar{e}$, o estabelecimen to estava voltado para outros produtos?.

2. Evolucão do mercado consumidor: E o mesmo? Qual era o tipo predomi nante anteriormente? Calsse media, pobre, rica, proprietários rurais assalariados ruxais? Por que mudou a clientcla? Qual a tendencia.desta clientela do estabelecimento: para mais rica, média ou pobre? Por que? .

3. Na opinião do proprictário, em função de qual classe socio-econômi ca se define o comércio local? Há necessidade de outros tipos de = estabelecimentos comerciais cou de serviços? Quais? Por que?

4. Procurar saber quais os melhores periodos (anos, semestres) para a atividade concrcial ou de servisos, tanto no passado, quanto atual mence. Causas. Íem para os periodos considerados íracos.

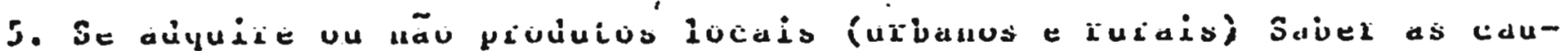
sas da aquisição ou não.

6. Perspctivas do comercio e scrvisos locais. Da sua atividade en particular. 
Pesquisa no comércio- Paraguaçu Paulista - ABASTECIMENTO - (ils.3) Firma comercial

Enderêço

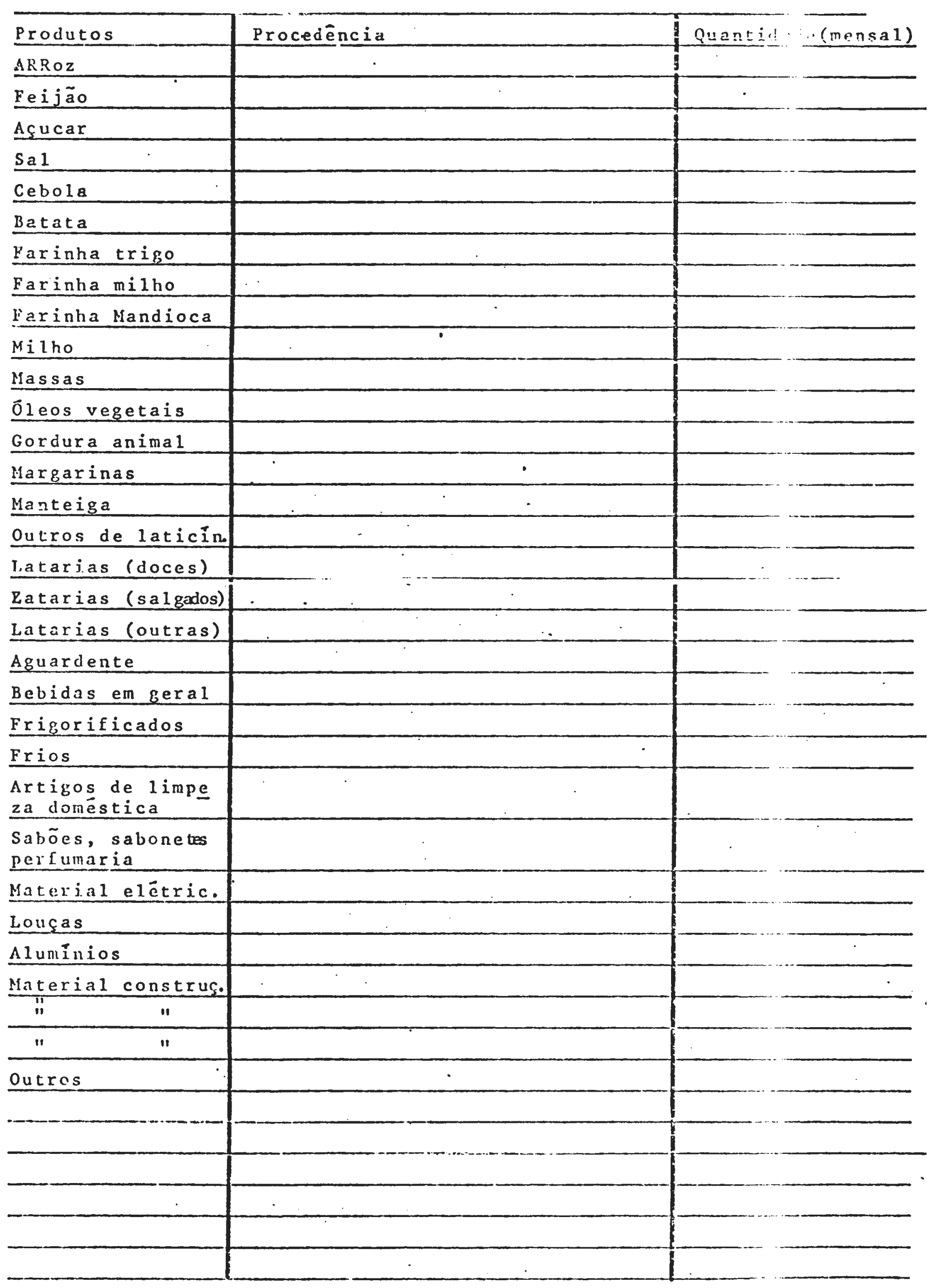




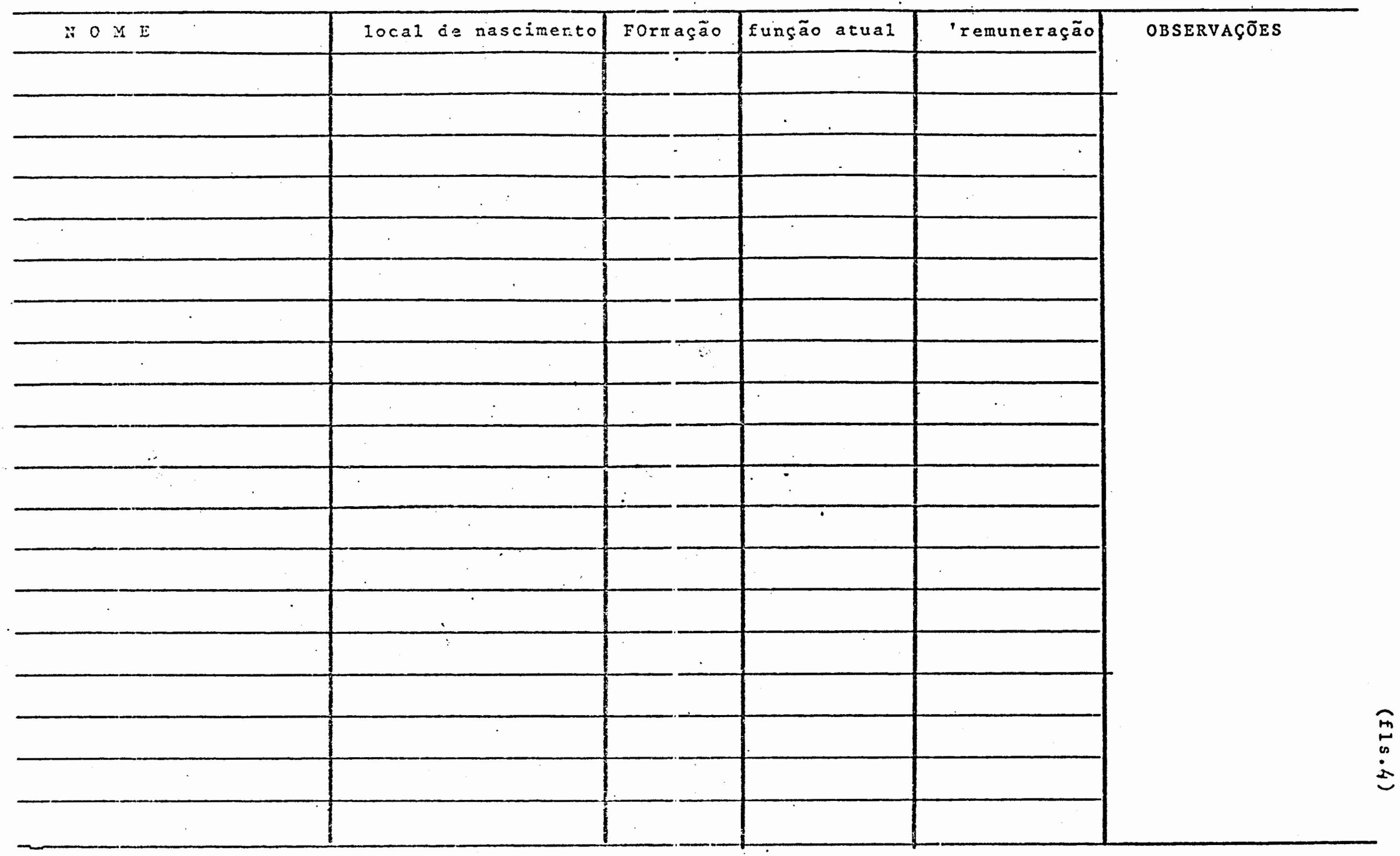




\section{( 1 s. 5}

\section{HISTORICO PROFISSIONAL DO PROPRIETARRIO}

(1- Avós: Onde nasceram? Onde residiram antes de Paraguaçu Paulista? Por que vieram para P. Paulista? O_que faziam anteriormente?

Quais as atividades que exerceram em P.Paulista?:colonos, / Assslariados, proprietários, comercinates, etc.? (Verificar as causas de mudanças de atividades e as épocas, se possível

(2- Pais: Idem aos avós

(3- Proprietärio: Local de nascimento. Onde residiu antes? (as värias residencias). Suas profissoes anteriores; Sua profissão atual causas das mudanças de profissōes. O que o levou a estabelecer-se no ramo atual. Origem do capital. Possui outras pro priedades? Tipos? O que o levou a adquiri-1as?.

Perspectivas futuras quanto ao seu estabelecimento em parti cular? (mudanças de profissão, de ramo de negócio,etc.. Caü sas.)

crāu de instrução. 
Questionārio a ser aplicado no Comércio e servicos de Paraguaçu Paulista.

Nome da firma ou estabelecimento

Atividade

Total de pessoas que trabalham no estabelecimento

$=-$

Vendas ou prestação de serviços:

A) * de vendas ou prestação serviços locais (especificamente à cida de de Paraguaçu Paulista) *

B) T de vendas ou prestação de serviços fora da cidade $\%$ Destas do item B :

1 . \% para a zona rural de Paraguaçu Paulista

2 . \% para outras zonas rurais.

Quais? (municipio) 男
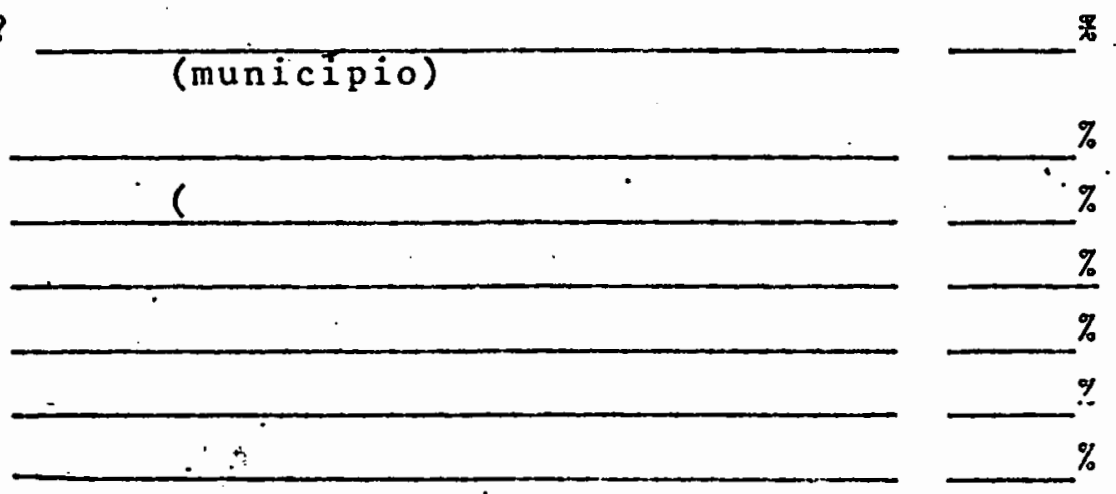

3. \% para cutras cidades Quais? (cidade) $\%$
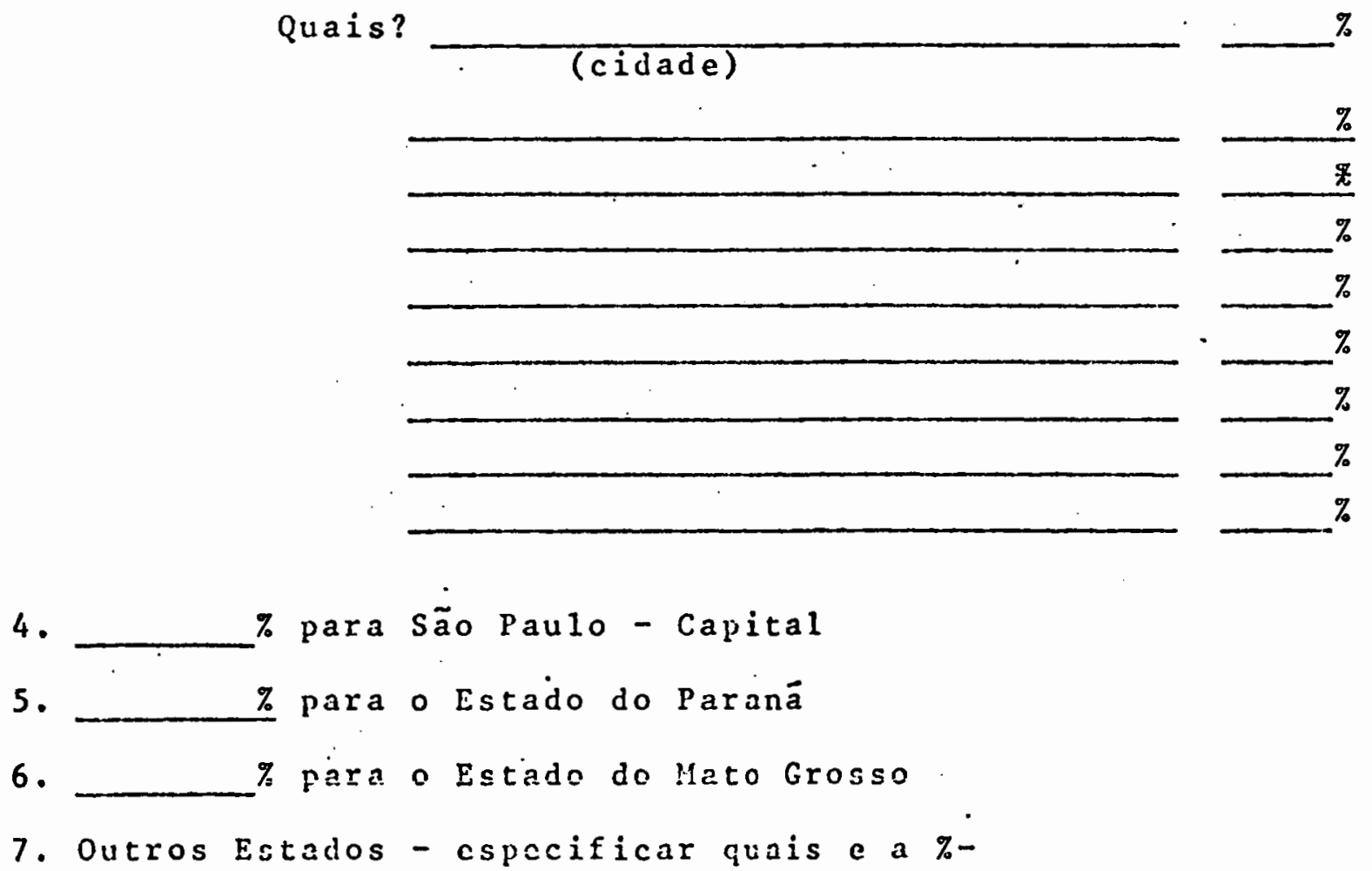


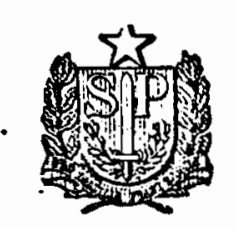

Secretaria da Fazenda do Estado de São Paulo Declaração de Dados Informativos Necessários à Apuração dos Indices de Participação dos Municiplos Paulistas

no Produto da Arrecadação do ICM PERIODO: 0l/0I/ a 31/12/ PROOUTOR AGROPECUARIO

\begin{tabular}{lll} 
Nome & \\
Enderţ̧o & \\
Distrito & $\cdot$ \\
\hline
\end{tabular}

\section{MODELO "A"}

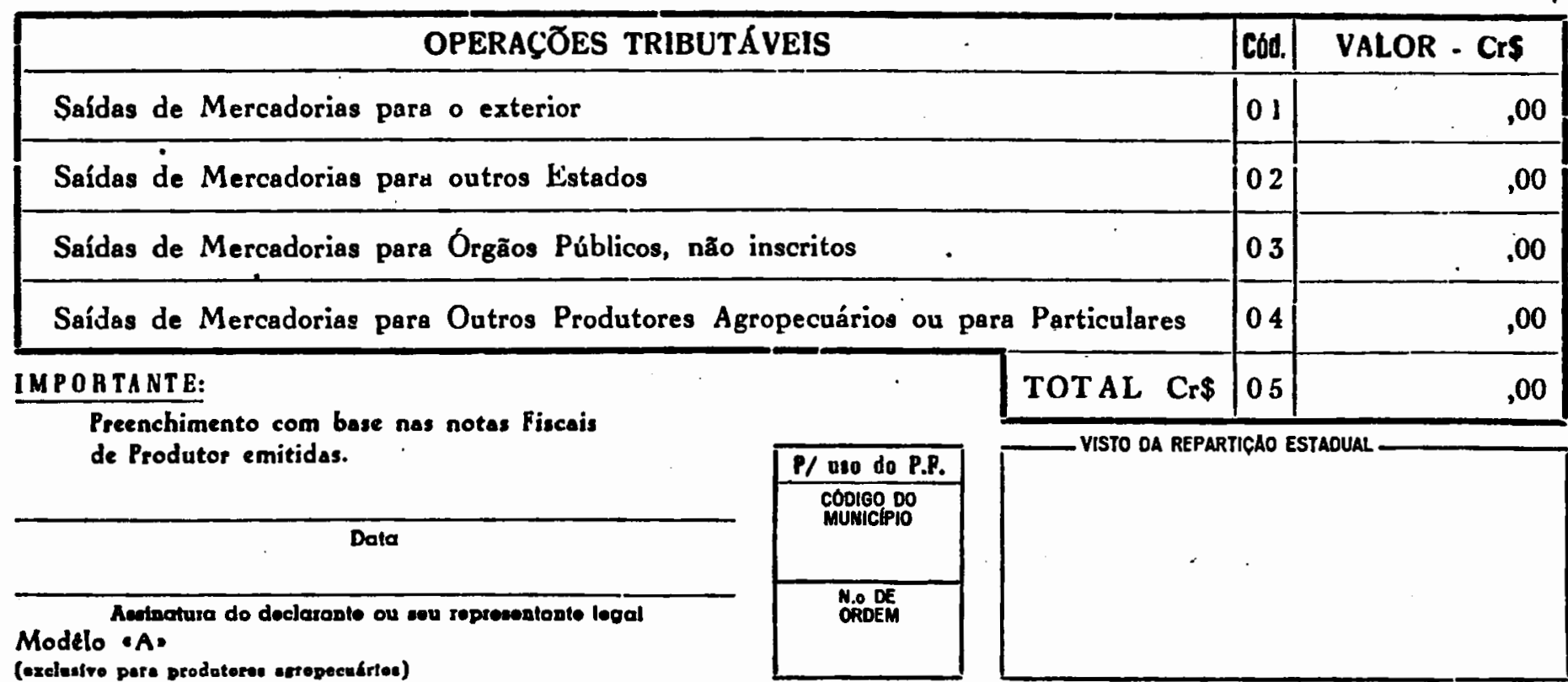


SECRETARIA DA PAZENDA DO ESTADO DE SAO PAULO DECLARAÇA DE DADOS INRORMATIVOS NECESSÁRIOS A APURACCAO DOS ÍNDICES DE PARTICIPACCAO DOS MUNICIPIOS PAULISTAS

NO PRODUTO DA ARRECADACAO DO ICM PERÍODO: 01/01/ a 31/12/

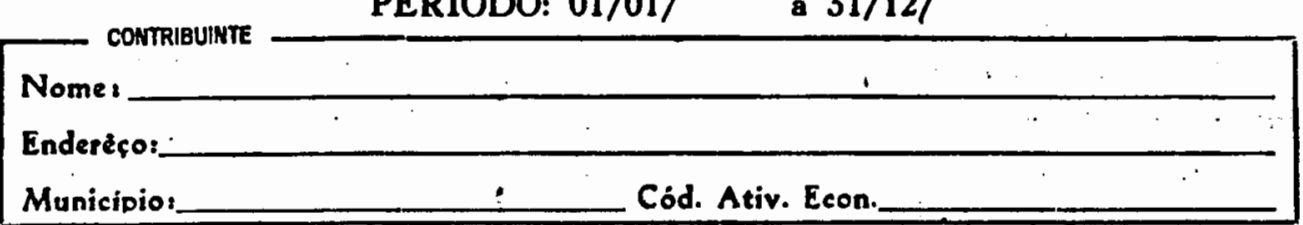

\section{MODELO "B"}

OPERACOES COM MERCADOHIAS OBJETO DF COMEACIALIZICAO E' OU INOUSTAIALIZAC'AO:

a) - tributóveis (tributadas $e$ isentas), b) - que distinem orodutos industrializados para o

exterior, c) - com livros. jornais e periódicos, ossim como ofbel destinado à sua impressäo.

[ INSCRiCAO ESTADUAL

\begin{tabular}{|c|c|}
\hline T I T ULO S \\
\hline SA IDAS
\end{tabular}

\section{S A Í D A S}

Vendas

Para o Estado

Para outros Estados.

Para o Exterior

Transferências:

Para o Estado

Para outros Estados

Apuradas mediante ação fiscal ou auto-denunciadas, nãa escrituradas

Saidas do estoque não compreendidas nos İtens anteriores.

Estoque final (inclusive 0 em poder de outros estabelecimentos)

Soma (Cód. $11+12+13+14+15+16+17+18)$

\section{EN T R A D A.S}

Comprzs

Do Estado (exceto as feitas a produtores agropecuários)

De outros Estados

Feitas a produtores agropecuários, do Estado

Houve Compras à Produtores Agrodecuários do Estado?

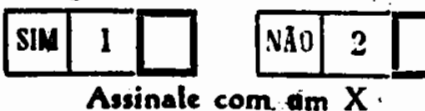

Assinale com, im $X$.

\begin{tabular}{|c|c|}
\hline $\cos$. & VALOR = Cr\$ \\
\hline 11 & $\begin{array}{r}\vdots \\
\quad 00 \\
\end{array}$ \\
\hline 12 & .00 \\
\hline 13 &, 00 \\
\hline 14 & $\begin{array}{r}00 \\
\end{array}$ \\
\hline 15 &, 00 \\
\hline 16 & .00 \\
\hline 17 & .00 \\
\hline 18 &, 00 \\
\hline 19 & .00 \\
\hline 20 & $\cdots \quad \cdot$ \\
\hline 21 & .00 \\
\hline 22 & .00 \\
\hline 23 & .00 \\
\hline 24 & .00 \\
\hline 25 & .00 \\
\hline 26 & ,00 \\
\hline 27 & .00 \\
\hline 28 & .00 \\
\hline 29 & .00 \\
\hline 30 & .00 \\
\hline 31 & .00 \\
\hline 32 & .00 \\
\hline 33 & .00 \\
\hline
\end{tabular}

Importaçōes do Exterior

Transferências:

Do Estado

De outros Estados

Apuradas mediante ação fiscal ou auto-denunciadas, não escrituradas:

Operações (exceto as com produtores agropecuários, do Estado)

Operações com produtores agropecuários, do Estado

Entradas no esłoque não compreendidas nos Ítens anteriores

Estoque inicial (inclusive o em poder de outros estabelecimentos)

Soma (Cód. $20+21+22+23+24+25+26+27+28+29$ )

Diferença (Cód. $19-30$ )

Total das Importações do Exterior (Código $23+$ importações de mercadorias para uso e ou consumo própriol

VALOR ADICIONADO (Cód. $31+32$ )

O.BSER VAC OES:

1. Os valores does Códigos 22.27 deverbo ser desdobrados, no verso, por municipio de origem:

2. Hio deverio ser declaradas as operaçios com morcadorias que devam rotornat ao estabelecimento do origem.

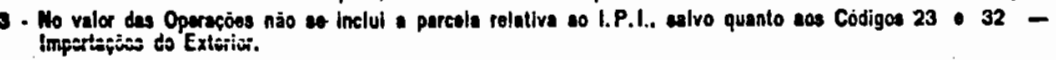


Compras Feitas a Produtores Agropecuários. do Estado - “999” - · Fl. N.o [Inacriça Eutadual _ _

\begin{tabular}{|c|c|c|c|c|c|}
\hline 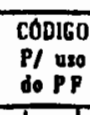 & $\begin{array}{c}\begin{array}{c}\text { Munlciplos de Origem das Mercadorlas } \\
\text { [em ordem alfabélical }\end{array} \\
\end{array}$ & VALOR - Crs & 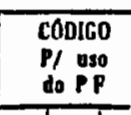 & $\begin{array}{l}\text { Alunicipios ve Oripem das Mercadorias } \\
\text { (em ordem aliabelica) }\end{array}$ & VALOR - CI\$ \\
\hline & Do próprio Município & .00 & & & .00 \\
\hline & & .00 & . & & .00 \\
\hline & & .00 & $\therefore$ & & .00 \\
\hline & & .00 & & & .00 \\
\hline & & .00 & & & .00 \\
\hline & & .00 & & & .00 \\
\hline & & .00 & - & & .00 \\
\hline & & .00 & & & .00 \\
\hline & & .00 & & & .00 \\
\hline & & .00 & & & .00 \\
\hline & & .00 & & & .00 \\
\hline & & .00 & & & .00 \\
\hline & & .00 & & & .00 \\
\hline & & .00 & & & .00 \\
\hline & & .00 & & & .00 \\
\hline & & .00 & & & .00 \\
\hline & & .00 & & & .00 \\
\hline & & .00 & & & .00 \\
\hline & & .00 & & & .00 \\
\hline & & .00 & & & .00 \\
\hline & & .00 & & - & .00 \\
\hline & &.$\quad 00$ & & & .00 \\
\hline & & .00 & & & .00 \\
\hline & & .00 & & & .00 \\
\hline & & .00 & & & .00 \\
\hline & & .00 & & & .00 \\
\hline & & .00 & & $\therefore$ & .00 \\
\hline & & .00 & & &, 00 \\
\hline & & .00 & & & .00 \\
\hline & & .00 & & & .00 \\
\hline & & .00 & & & .00 \\
\hline & & .00 & & & .00 \\
\hline & & .00 & & & .00 \\
\hline & & .00 & & & .00 \\
\hline & & .00 & & & .00 \\
\hline & & .00 & 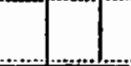 & & .00 \\
\hline
\end{tabular}


A digitalização deste documento foi possível graças ao investimento do Programa de Pós-graduação em Geografia Humana (PPGH-FFLCH-USP) e realizada com recursos da Coordenação de Aperfeiçoamento de Pessoal de Nível Superior - Brasil (CAPES) - Código de Financiamento 001. Essa ação integra as atividades de comemoração dos 50 anos do PPGH no ano de 2021. Para mais informações sobre o PPGH e sua história, visite a página do programa: http://ppgh.fflch.usp.br/.

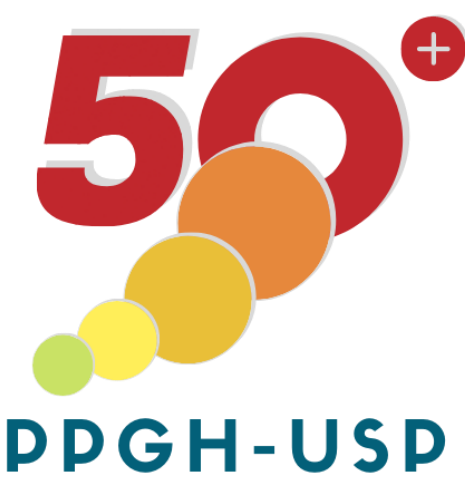

$1971-2021$ 